МЕЖДУНАРОДНЫЙ

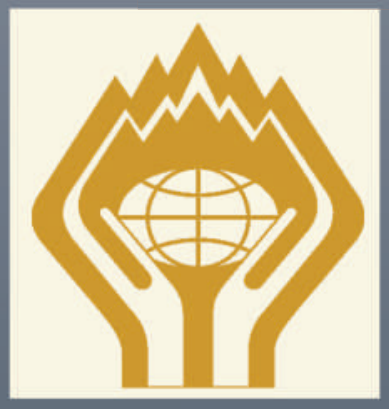

НАУЧНЫЙ ЖУРНАЛ

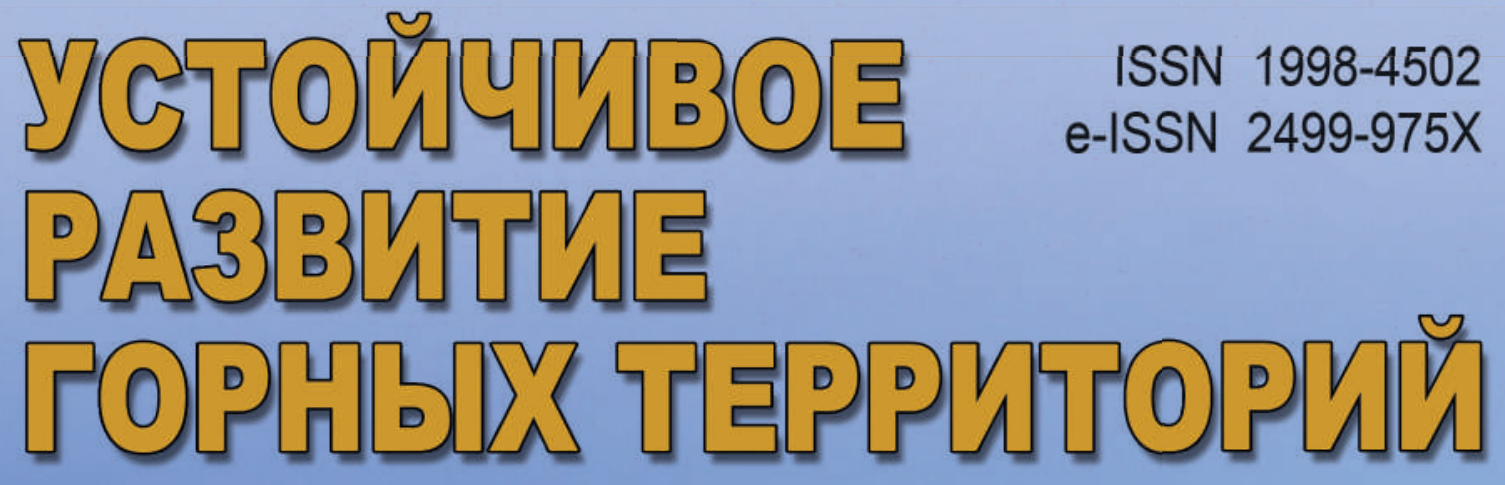

Sustajinable Development of Mountain Territories
“Земля - планета не простая". А. де Сент-Экзюпери

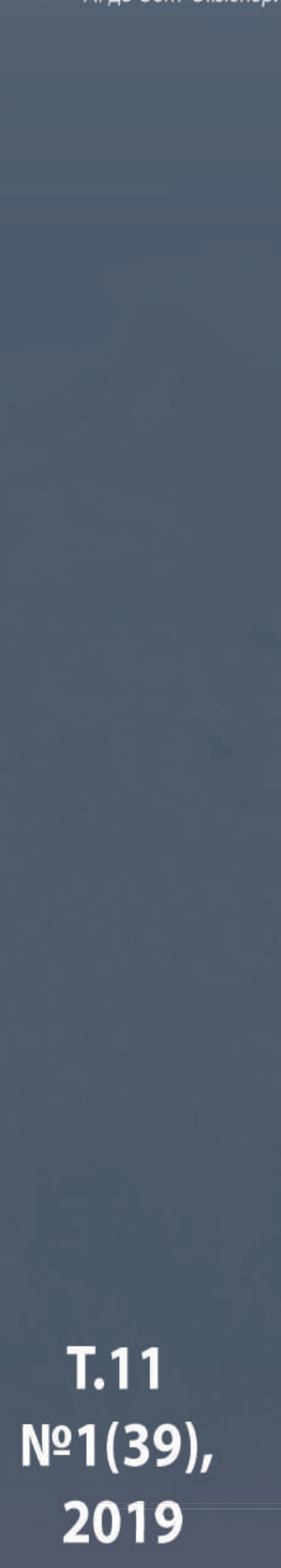

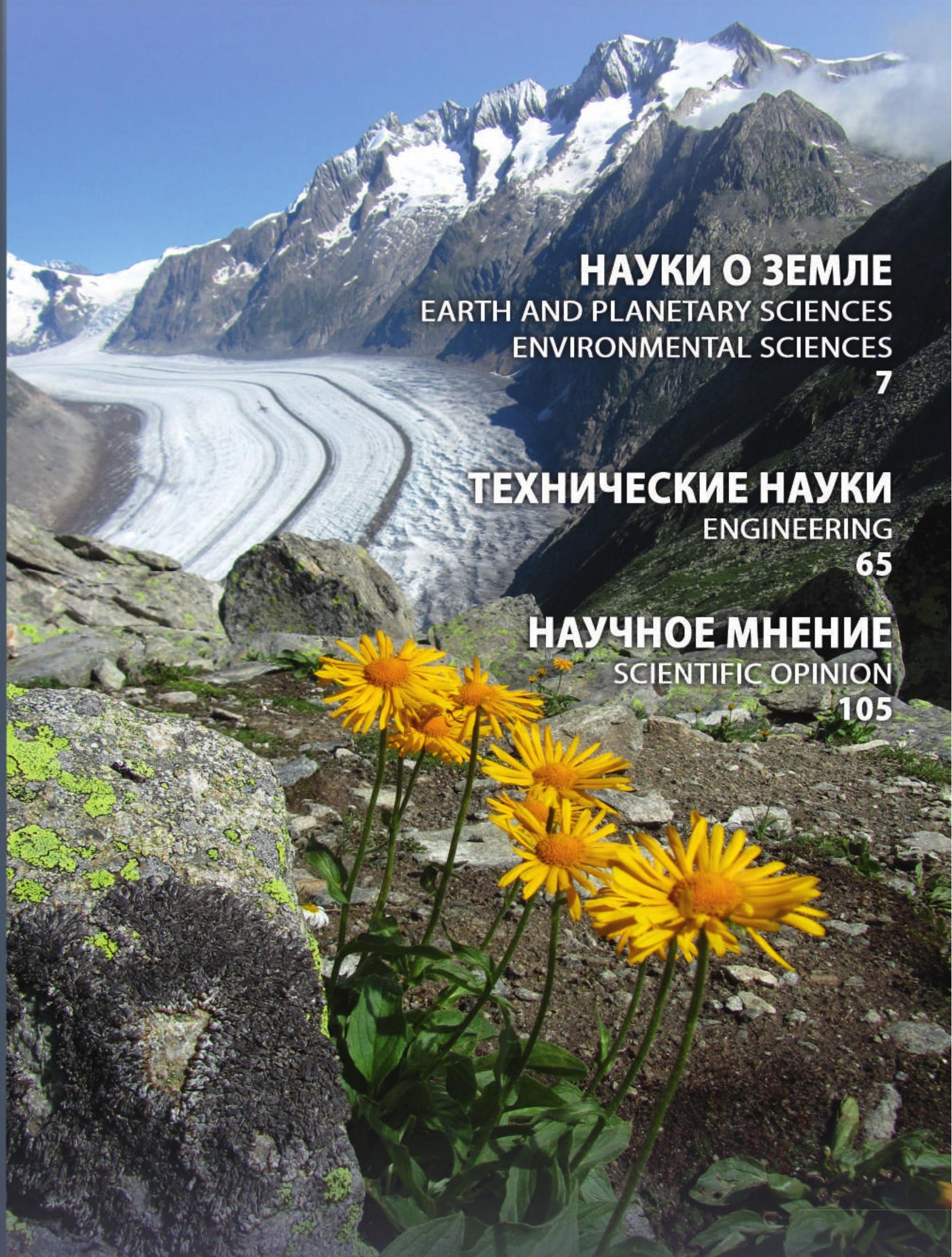




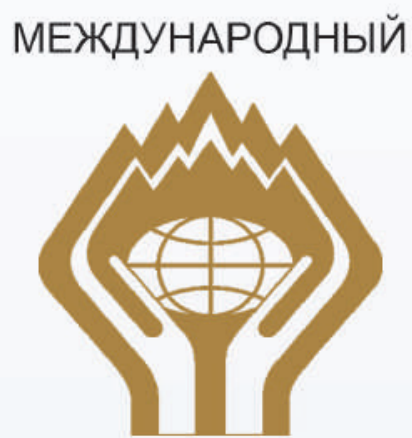

\section{НАУЧНЫЙ ЖУРНАЛ "УСТОЙЧИВОЕ РАЗВИТИЕ ГОРНЫХ ТЕРРИТОРИЙ"}

Журнал входит в Перечень изданий, рекомендованных Высшей аттестационной комиссией (ВАК)

Журнал включен в международную реферативную базу данных и систему цитирования Scopus

\section{Адрес редакции, учредителя, издателя: \\ 362021, РСО-Алания,}

г. Владикавказ, ул. Николаева, 44,

Северо-Кавказский горно-

металлургический институт

(государственный технологический университет)

редакция журнала «Устойчивое развитие горных территорий».

Тел.: 8(8672) 40-73-60, $8(918) 707-39-25$ $8(8672)$ 40-72-28

\section{Адрес в Интернете:}

http://www.naukagor.ru

E-mail: editor@naukagor.ru

Ответственность за содержание статей несут авторы.

Редакция не имеет возможности возвращать присылаемые материаль За сведения в рекламных материалах редакция ответственности не несет.

Перепечатка допускается только с разрешения редакции

и с обязательной ссылкой на журнал «Устойчивое развитие горных территорий».

Журнал зарегистрирован в Федеральной службе по надзору за соблюдением законодательства в сфере массовых коммуникаций и охраны культурного наследия.

Свидетельство о регистрации

ПИ №ФС77-27831 от 19.04.2007 Издается с 2009 г.

Редактор МИСИКОВА И.А.

Технический перевод ПЕЙКАРОВА Н.И. Компьютерный дизайн

и верстка ПРОВОТОРОВА Н.М.

Тираж 500 экз. Заказ №23

Подписано в печать: 25.03.2019 г

Дата фактического выхода: 29.03.2019 г.

Отпечатано в типограсии ИП Могилевский Е.С.

344064, г. Ростов-на-Дону, ул. 2-й Пятилетки 23У.

(c) «Устойчивое развитие горных территорий», 2019

\section{УЧРЕДИТЕЛЬ :}

СЕВЕРО-КАВКАЗСКИЙ ГОРНО-МЕТАЛЛУРГИЧЕСКИЙ ИНСТИТУТ (ГОСУДАРСТВЕННЫЙ ТЕХНОЛОГИЧЕСКИЙ УНИВЕРСИТЕТ

\section{РЕДАКЦИОННАЯ КОЛЛЕГИЯ}

Главный редактор - Дмитрак Юрий Витальевич - доктор технических наук, профессор, ректор Северо-Кавказского горно-металлургического института (государственного технологического университета), (Владикавказ, Россия).

\section{ПЕРВЫЙ ЗАМЕСТИТЕЛЬ ГЛАВНОГО РЕДАКТОРА:}

Хадзарагова Е.А. - доктор технических наук, профессор, проректор по научной работе и инновационной деятельности Северо-Кавказского горно-металлургического института (государственного технологического университета) (Владикавказ, Россия)

\section{ЗАМЕСТИТЕЛИ ГЛАВНОГО РЕДАКТОРА:}

Клюев Р.В. - доктор технических наук, профессор, заведующий кафедрой «Электроснабжение промышленных предприятий» Северо-Кавказского горно-металлургического института (государственного технологического университета), ответственный за выпуск номеров журнала, (Владикавказ, Россия).

Гуня А.Н. - доктор географических наук, профессор, руководитель горной группы МАВ-6 программы ЮНЕСКО «Человек и биосфера» в Институте географии Российской Академии наук, старший научный сотрудник ИГ РАН, (Москва, Россия). Иетагуров В.Н. - доктор технических наук, профессор, руководитепь рабочей группы по подготовке журнала к изданию, Хетагуров В.Н. - доктор технических наук, профессор, руководитель рабочей группы по подготовке журнала к изданию, та (государственного технологического университета), (Владикавказ, Россия).

\section{ОТВЕТСТВЕННЫЕ СЕКРЕТАРИ (по направлениям)}

Науки о Земле - Хацаева Ф.М. - кандидат географических наук, доцент, декан фракультета географии и геоэкологии, заведующий кафедрой «Геоэкология и землеустройство» Северо-Осетинского государственного университета им. К.Л. Хетагурова, Председатель отделения Русского географического общества в Республике Северная Осетия-Алания, (Владикавказ Россия).

Экология - Гриднев Е.А. - кандидат технических наук, доцент кафедры «Экология и техносферная безопасность» Северо-Кавказского горно-металлургического института (государственного технологического университета), (Владикавказ, Россия)

Технические науки - Лолаев А.Б - доктор технических наук, заведующий кафедрой «Автомобильные дороги и аэродромы» Северо-Кавказского горно-металлургического института (государственного технологического университета), (Владикавказ, Россия).

РЕДАКТОРЫ:

Караев Ю.И. - директор Международного инновационного научно-технологического центра «Устойчивое развитие горных территорий» (МИНТЦ «Горы») Северо-Кавказского горно-металлургического института (государственного технологического университета), (Владикавказ, Россия).

Мисикова И.А. - начальник редакционно-издательского отдела Северо-Кавказского горно-металлургического института (государственного технологического университета), (Владикавказ, Россия).

\section{РЕДАКЦИОННЫЙ СОВЕТ:}

\section{Председатель редакционного совета:}

Котляков В.М. - доктор географических наук, академик РАН, Почётный президент Русского географического общества, председатель экспертного совета Национальной премии «Хрустальный компас», член Межправительственной группь экспертов по проблеме изменения климата, (Москва, Россия).

\section{СОПРЕДСЕДАТЕЛИ РЕДАКЦИОННОГО СОВЕТА}

Вейнгартнер Р. - доктор наук, профессор Университета г. Берн (Швейцария), заведующий кафедрой гидрологии Географического института Университета г. Берн. Руководитель Международной Исследовательской Инициативы (MRI), (г. Берн, Швейцария)

Дзасохов А.С. - доктор политических наук, заместитель председателя Комиссии Российской Федерации по делам ЮНЕСКО, (Москва, Россия)

Кавалла Р. - кандидат технических наук, профессор, директор института обработки металлов давлением Фрайбергской Горной Академии, (Фрайберг, Германия).

Пучков Л.А. - доктор технических наук, профессор, член корр. РАН, профессор кафедры «Безопасность и экология горного производства» Горного института Национального исследовательского технологического университета «Московский институт стали и сплавов», (Москва, Россия).

\section{СОСТАВ РЕДАКЦИОННОГО СОВЕТА:}

Айдаралиев А.А. - доктор медицинских наук, академик Национальной Академии наук Республики Кыргызстан, Председатель попечительского Совета УНПК «Международный университет Кыргызстана», (Бишкек, Кыргызская Республика). Бабаян Г.А. - кандидат физико-математических наук, заведующий отделом мониторинга и инноваций Института геологических наук Национальной Академии наук Армении, (Ереван, Республика Армения).

Баденков Ю.П. - кандидат геолого-минералогических наук, ведущий научный сотрудник Института географии РАН, научный руководитель горной группы МАВ-6 программы ЮНЕСКО «Человек и биосфера» в Институте географии РАН, (Москва, Россия).

Большаков В.Н. - доктор биологических наук, профессор, академик Российской академии наук, Советник РАН, главный научный сотрудник, заведующий лабораторией эволюционной экологии Института экологии растений и животных УрО РАН, (Москва-Екатеринбург, Россия).

Вагин В.С. - доктор экономических наук, профессор, директор Института международного образования Южно-Российского государственного политехнического университета (Новочеркасского политехнического института), (Новочеркасск, Россия).

Викторов С.Д. - доктор технических наук, профессор, заместитель директора по научной работе Института проблем комплексного освоения недр РАН, (Москва, Россия).

Винчигуерра С. - доцент кафедры наук о Земле Университета Турина, (Турин, Италия).

Глазырина И.П. - доктор экономических наук, кандидат физико-математических наук, профессор, заведующая кафедрой «Прикладная информатика и математика» Забайкальского государственного университета, (Чита, Россия).

Голик В.И. - доктор технических наук, профессор; профессор кафедры «Технология разработки месторождений» СеГолик В.И. - доктор технических наук, профессор; просрессор кафедры «Технология разработки месторождений» Северо-Кав

Гроппен В.О. - доктор технических наук, профессор, заведующий кафедрой «Автоматизированная обработка информации» Северо-Кавказского горно-металлургического института (государственного технологического университета), (Владикавказ, Россия).

Дребенштедт К. - профессор, декан Фрайбергской горной Академии, (Фрайберг, Германия).

Заксенхофер Р. - заведующий кафедрой нефтегазовой геологии, профессор Горного университета в Леобене, (Леобен, Австрия).

Залиханов М.Ч. - доктор географических наук, профессор, академик РАН, Главный научный сотрудник Высокогорного геофизического института Росгидромета, (Нальчик, Россия).

Кондратьев Ю.И. - доктор технических наук, профессор Северо-Кавказского горно-металлургического института (госуКондратьев Ю.И. - доктор технических наук, профессор Северо-Кав

Лурье П.М. - доктор географических наук, профессор, ведущий метеоролог Северо-Кавказского управления по гидрометеорологии и мониторингу окружающей среды, (Ростов-на-Дону, Россия).

Матвеева Л.Г. - доктор экономических наук, профессор, заведующая кафедрой «Информационная экономика» экономического факультета Южного федерального университета, (Ростов-на-Дону, Россия).

Минцаев М.Ш. - доктор технических наук, профессор, ректор Грозненского государственного нефтяного технического университет им. акад. М.Д. Миллионщикова, (Грозный, Россия)

Прхалова М. - программный специалист отдела «Экология и науки о Земле» Секретариата ЮНЕСКО, (Париж, Франция). Ревякин В.С. - доктор географических наук, профессор кафедры «Общая география» Национального исследовательРевякин В.С. - доктор географических наук, профессор кафедры «Общая география» Национального исследовательского Томского государственного ун

ных центров мира, (Алтай, Россия). государственного политехнического университета (НПИ) имени М.И. Платова, (Новочеркасск, Россия)

Темираев Р.Б. - доктор сельско-хозяйственных наук, профессор, заведующий кафедрой «Технология продуктов общественного питания» Северо-Кавказского горно-металлургического института (государственного технологического университета), (Владикавказ, Россия).

Хосаев Х.С. - доктор технических наук, профессор кафедры «Теоретическая и прикладная механика» Северо-Кавказского горно-металлургического института (государственного технологического университета), (Владикавказ, Россия).

Штадельбауэр Й. - доктор философских наук, профессор Фрайбургского университета, (Фрайберг, Германия). 
FOUNDER:

\section{EDITORIAL TEAM:}

Chief Editor - Yuri V. Dmitrak - Professor, Rector of the North Caucasian Institute of Mining and Metallurgy(State Technological University) (Vladikavkaz, Russia).

\section{FIRST DEPUTY OF DITOR-IN-CHIEF:}

Elena A. Khadzaragova - Doctor of Technical Sciences, Professor, Vice-Rector on Research and Innovation North-Caucasian Institute of Mining and Metallurgy (State Technological University), (Vladikavkaz, Russia).

\section{DEPUTY CHIEF EDITORS:}

Roman V. Klyuev - Doctor of Technical Science, Professor, Head of Department of Power Supply of Industrial Enterprises, North Caucasian Institute of Mining and Metallurgy (State Technological University) (Vladikavkaz, Russia).

Alexey N. Gunya - Dr. Sci. in Geography, Professor, Head of Mountain Group MAB-6 aided by UNESCO "Man and Biosphere" Program, Institute of Geography, Russian Academy of Science, Senior Research Associate of IG RAS (Moscow, Russia).

Valery N. Khetagurov - Doctor of Technical Science, Professor of Department of Technological Science and Equipment, North Caucasian Institute of Mining and Metallurgy (State Technological University) (Vladikavkaz, Russia).

\section{EXECUTIVE EDITORS (by areas of activity):}

Earth Sciences - Fatima M. Khatsaeva - Cand. Sc. in Geography, Associate Professor, Dean of Faculty of Geography and Geoecology, Head of Department Geoecology and Land Management Department of North Ossetian State University, Chairman of North Ossetian Department of Russian Geographical Society (Vladikavkaz, Russia).

Ecology - Yevgeny A. Gridnev - Cand. Sc. (Engineering), Associate Professor of Department of Ecology and Technosphere Safety, North Caucasian Institute of Mining and Metallurgy (State Technological University) (Vladikavkaz, Russia).

Engineering Sciences - Alan B. Lolaev - Doctor in Technical Science, Professor, Head of Department of Automobile Roads and Aerodromes, North Caucasian Institute of Mining and Metallurgy (State Technological University) (Vladikavkaz, Russia)

\section{EDITORS}

Yuri I. Karaev - Director of International Innovation Scientific Technological Centre Sustainable Development of Mountain Territories, North Caucasian Institute of Mining and Metallurgy (State Technological University) (Vladikavkaz, Russia).

Indira A. Misikova - Head of Editorial Department, North Caucasian Institute of Mining and Metallurgy (State Technological University) (Vladikavkaz, Russia).

\section{EDITORIAL BOARD:}

\section{Chairman:}

Vladimir M. Kotlyakov - Dr. Sci. in Geography, Member of Russian Academy of Science, Honorary President of Russian Geographical Society, Chairman of Expert Board of Crystal Compass National Award, Member of Intergovernmental Panel on Climate Change (Moscow, Russia)

\section{CO-CHAIRS:}

Rolf Weingartner - Doctor of Science, Professor of University of Bern (Switzerland), Head of Department of Hydrology, Institute of Geography, University of Bern. Supervisor of International Research Initiative (MRI) (Bern, Switzerland).

Alexander S. Dzasokhov - Doctor of Political Science, Deputy Chairman of Russian Commission for UNESCO (Moscow, Russia) Rudolf Kawalla - Doctor of Technical Science, Professor, Director of Institute of Metal Processing Pressure, Freiberg University of Mining and Technology (Freiberg, Germany).

Lev A. Puchkov - Doctor in Technical Science, Professor, Corresponding Member of Russian Academy of Science, Member of Academy of Natural Sciences, Member of International Academy of Higher Education, Professor of Department of Safety and Ecology of Mining Industry, College of Mining, National University of Science and Technology MISiS (Moscow, Russia).

\section{MEMBERS OF EDITORIAL BOARD:}

Asylbek A. Aidaraliev - Dr. habil. in Medicine, Member of National academy of Science of Kyrgyz Republic, Head of UNESCO Department of Sustainable Mountain Development and Chairman of Supervisory Board of Educational Research and Production Complex «International University of Kyrgyzstan» (Bishkek, Kyrgyz Republic).

Hector A. Babayan - Cand. Sc. (Physics and Mathematics), Head of Department of Monitoring and Innovation, Institute of Geological Sciences, National Academy of Science, Republic of Armenia (Yerevan, Republic of Armenia).

Yuri P. Badenkov - Cand. Sc. in Geology and Mineralogy, Leading Research Associate of Institute of Geography of Russian Academy of Science, Scientific Supervisor of Mountain Group MAB-6, Man and Biosphere Program by UNESCO, Institute of Geography of RAS (Moscow, Russia).

Yuri N. Bolshakov - Dr. Sci. in Biology, Professor, Member of Russian Academy of Science, Adviser to RAS, Senior Research Associate, Head of Laboratory of Evolutionary Ecology, Institute of Plant and Animal Ecology, Ural Department of Russian Academy of Science (Moscow-Yekaterinburg, Russia).

Vladimir S. Vagin - Doctor of Economics, Professor, Director of Institute of International Education, South Russian State Polytechnic University (Novocherkassk Polytechnic Institute) (Novocherkassk, Russia).

Sergey D. Viktorov - Doctor in Technical Science, Professor, Deputy Director for Research Institute of Comprehensive Exploitation of Subsoil, Russian Academy of Science (Moscow, Russia).

Serjio Vinciguerra - Associate Professor of the Department "Earth Sciences" University of Turin (Turin, Italy).

Irina P. Glazyrina - Doctor in Economics, Cand. Sc. in Physics and Mathematics, Head of Department of Applied Mathematics and Informatics, Trans-Baikal State University (Chita, Russia).

Vladimir I. Golik. - Doctor of Technical Sciences, Professor, Professor of the Department "Development of mineral deposits" North-Caucasian Institute of Mining and Metallurgy (State Technological University) (Vladikavkaz, Russia).

Vitaly O. Groppen - Doctor in Technical Science, Professor, Head of Department of Automated Processing of Information, North Caucasian Institute of Mining and Metallurgy (State Technological University) (Vladikavkaz, Russia).

Carsten Drebenstedt - Dean of the Freiberg Mining Academy, Professor (Freiberg, Germany).

Rainhad Sachsenhofer - Head of the Department "Petroleum Geology", Professor of Leoben Mining University (Leoben, Austria) Mikhail Ch. Zalikhanov - Dr. Sci. in Geography, Professor, Member of Russian Academy of Science, Senior Research Associate, High-Mountain Geophysical Institute of Federal Service for Hydrometeorology and Environmental Monitoring of Russia (Nalchik, Russia).

Yuri I. Kondratyev - Doctor Technical Science, Professor, North Caucasian Institute of Mining and Metallurgy (State Technological University) (Vladikavkaz, Russia).

Pyotr M. Lur'e - Dr. Sci. in Geography, Professor, Leading Meteorologist, North Caucasian Department of Hydrometeorology and Environmental Monitoring (Rostov-on-Don, Russia).

Lyudmila G. Matveeva - Doctor in Economics, Head of Department of Information Economy, Faculty of Economics, South Federal University (Rostov-on-Don, Russia).

Magomed Sh. Mintsaev - Doctor in Technical Science, Professor, Vice Rector for Research and Innovation, Acad. M. D. Millionshchikov Grozny State Oil Technical University (Grozny, Russia).

Marie Prchalova - Programme Specialist, Division of Ecological and Earth Sciences, UNESCO Secretariat.

Viktor S. Revyakin - Dr. Sci. in Geography, Professor of Department of General Geography, National Research Tomsk State University, Head of Altai-Sayans Regional Group of World Mountain Centers Network, Member of Russian Academy of Natural Sciences and Russian Ecological Academy (Barnaul, Russia).

Nikolay I. Sysoev - Doctor in Technical Science, Professor of Department of Petroleum Engineering and Technology, South Russian State Polytechnic University (Novocherkassk Polytechnic Institute) (Novocherkassk, Russia).

Rustem B. Temiraev - Doctor of Agricultural Sciences, Professor, Head of the Department "Food technology" North-Caucasian Institute of Mining and Metallurgy (State Technological University), (Vladikavkaz, Russia).

Khazbi S. Khosaev - Doctor of Technical Science, Professor, Deputy Director of Centre for International Cooperation, External Relations and Sustainable Development, North Caucasian Institute of Mining and Metallurgy (State Technological University) (Vladikavkaz, Russia)

Jorg Stadelbauer - Dr. Phil., Professor of University of Freiburg (Germany).

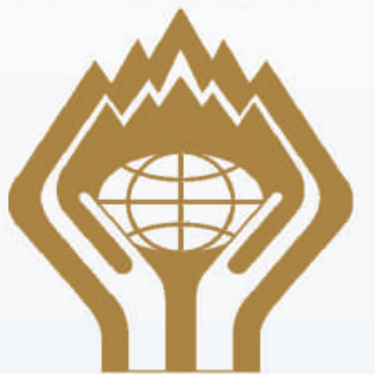

SCIENTIFIC JOURNAL

"SUSTAINABLE DEVELOPMENT OF MOUNTAIN TERRITORIES"

The journal is included in the List of publications recommended by Supreme

Attestation Commission (VAK)

The journal is included in the Internationa Reference Database and Scopus citation System

Address of the editorial office, founder, publisher:

44 Nikolaev Street, Vladikavkaz, RNO-Alania, 362021 , NORTH CAUCASIAN INSTITUTE OF MINING AND METALLURGY

(STATE TECHNOLOGICAL UNIVERSITY)

Editorial Office of the journal "Sustainable

Development of Mountain Territories". Tel.: +7 (8672) 40-73-60, $+7(918) 707-39-25$, +7 (8672) 40-72-28.

Internet address: http://www.naukagor.ru E-mail: editor@naukagor.ru

Authors are responsible for the content of the articles.

Editorial staff is not in the position to return the submitted materials.

Editorial staff is not responsible for the information in promotional materials. Reprinting is allowed only with the permission of the editorial office and reference to the journal

«Sustainable Development of Mountain Territories» is required.

The journal is registered in the Federa Service for Media Law Compliance and Cultural Heritage Protection.

Registration Certificate PI No FS 77-27831 From April, 192007

Published since 2009 Is free Editor MISIKOVA I.A.

Technical translation

PEYKAROVA N.I.

Computer design and make-up PROVOTOROVA N.M.

Covering -500 copies

Order No 23

Signed to print: 25.03.2019

Date of actual release: 29.03.2019

Printed by IE E.S. Mogilevsky, $23 \mathrm{U} 2$ Pyatiletki st.

344064, Rostov-on-Don

(C) «Sustainable development of mountain territories», 2019 


\section{СОДЕРЖАНИЕ}

НАУКИ О ЗЕМЛЕ

Босиков И.И., Клюев Р.В., Егорова Е.В.

ОЦЕНКА ПЕРСПЕКТИВ НЕФТЕГАЗОНОСНОСТИ СЕВЕРО-ВОСТОЧНОГО БЛОКА ЮЖНОХУЛЫМСКОГО МЕСТОРОЖДЕНИЯ

Забелина И.А., Делюга А.В.

ГЕОЭКОЛОГИЧЕСКИЕ ИНДИКАТОРЫ УСТОЙЧИВОГО РАЗВИТИЯ: ПРОСТРАНСТВЕННЫЙ АНАЛИЗ

Mehrabi A., Khabazi M., Almodaresi S.A., Nohesara M., Derakhshani R.

LAND USE CHANGES MONITORING OVER 30 YEARS AND PREDICTION OF FUTURE CHANGES USING MULTI-TEMPORAL LANDSAT IMAGERY AND THE LAND CHANGE MODELER TOOLS IN RAFSANJAN CITY (IRAN)

Кюль Е.В., Езаов А.К., Канкулова Л.И.

ТЕОРЕТИЧЕСКИЕ ОСНОВЫ

ГЕОЭКОЛОГИЧЕСКОГО МОНИТОРИНГА ГОРНЫХ ГЕОСИСТЕМ

Тарихазер C.A.

СЕЛЕВЫЕ ПРОЦЕССЫ В АЗЕРБАЙДЖАНЕ

И МЕТЕОРОЛОГИЧЕСКИЕ ФАКТОРЫ

ИХ ФОРМИРОВАНИЯ

(НА ПРИМЕРЕ БОЛЬШОГО КАВКАЗА)

Мадаева М.З., Хадзарагова Е.А., Келехсаев В.Б., Олисаев А.C.

ПРОБЛЕМЫ РЕКУЛЬТИВАЦИИ

УГОЛЬНЫХ ШАХТ ДОНБАССА

7
ТЕХНИЧЕСКИЕ НАУКИ

65

Горелова Г.В., Борисова Д.В.

КОГНИТИВНЫЙ ИНСТРУМЕНТАРИЙ

ИССЛЕДОВАНИЯ МЕЖРЕГИОНАЛЬНОЙ

ЭКОНОМИЧЕСКОЙ ИНТЕГРАЦИИ

65

Клыков Ю.Г., Дмитрак Ю.В., Байматов К.К., Клыкова В.Б.

ДОИЗМЕЛЬЧЕНИЕ ПРОМПРОДУКТОВ

ОБОГАЩЕНИЯ МЕДНО-ПИРИТНОЙ РУДЫ

В МЕЛЬНИЦЕ ДР-500

Тарасов М.A.

МОДЕЛИРОВАНИЕ ПАРАМЕТРОВ

ФУНКЦИОНИРОВАНИЯ ВЫЕМОЧНОЙ МАШИНЫ

С ВИБРАЦИОННЫМ ВОЗДЕЙСТВИЕМ

НА ГОРНЫЕ ПОРОДЫ

Цидаев Б.С., Логачев А.В., Голик В.И.

ОБЕСПЕЧЕНИЕ ЭКОЛОГИЧЕСКОЙ

БЕЗОПАСНОСТИ ПРИ РАЗРАБОТКЕ

КТИ-ТЕБЕРДИНСКОГО ВОЛЬФРАМОВОГО

МЕСТОРОЖДЕНИЯ

98

НАУЧНОЕ МНЕНИЕ

Thang P.D., Thang H.H., Phuc L.Q.

TECHNOLOGICAL SOLUTIONS FOR INTENSIVE WORKING OF MEDIUM THICK INCLINED COAL SEAMS IN DIFFICULT CONDITIONS IN THE MINES OF THE QUANG NINH COAL BASIN

ИНФОРМАЦИЯ ДЛЯ АВТОРОВ

ПОДПИСКА 


\section{CONTENTS}

EARTH AND PLANETARY SCIENCES

\section{ENVIRONMENTAL SCIENCES}

I. I. Bosikov, R. V. Klyuev, E. V. Egorova ASSESSMENT OF OIL AND GAS POTENTIAL PROSPECTS OF THE NORTH EASTERN UNIT OF THE SOUTH KHULYM DEPOSIT

I. A. Zabelina, A. V. Deluga GEOECOLOGICAL INDICATORS OF SUSTAINABLE DEVELOPMENT: SPATIAL ANALYSIS

A. Mehrabi, M. Khabazi, S.A. Almodaresi, M. Nohesara, R. Derakhshani LAND USE CHANGES MONITORING OVER 30 YEARS AND PREDICTION OF FUTURE CHANGES USING MULTI-TEMPORAL LANDSAT IMAGERY AND THE LAND CHANGE MODELER TOOLS IN RAFSANJAN CITY (IRAN)

E. V. Kyul, L. I. Kankulova, A. K. Ezaov THE THEORETICAL BASIS OF GEOENVIRONMENTAL MONITORING OF THE MOUNTAIN GEOSYSTEMS

S. A. Tarihazer MUDFLOW PROCESSES IN AZERBAIJAN AND METEOROLOGICAL FACTORS OF THEIR FORMATION (ON THE EXAMPLE OF THE GREATER CAUCASUS)

M. Z. Madaeva, E. A. Khadzaragova, V. B. Keleksaev, A. S. Olisaev PROBLEMS OF DONBASS COAL MINES RECULTIVATION

\section{ENGINEERING}

G. V. Gorelova, D. V. Borisova COGNITIVE TOOLS FOR THE INTER-REGIONAL ECONOMIC INTEGRATION STUDY

Yu. G. Klykov, Yu. V. Dmitrak,

K. K. Baimatov, V. B. Klykova

MILLING OF THE COPPER-PYRITICORE

ENRICHMENT PRODUCT

IN THE MILL DR-500

M. A. Tarasov

MODELING OF OPERATING PARAMETERS OF MINING MACHINES WITH VIBRATION ON THE ROCKS

B. S. Tsidaev, A. V. Logachev, V. I. Golik* PROFITABILITY INCREASE FOR OIL PRODUCTION BY DIVERSIFICATION OF TECHNOLOGIES

SCIENTIFIC OPINION

P. D. Thang, H.H. Thang, L.Q. Phuc TECHNOLOGICAL SOLUTIONS FOR INTENSIVE WORKING OF MEDIUM T HICK INCLINED COAL SEAMS IN DIFFICULT CONDITIONS IN THE MINES OF THE QUANG NINH COAL BASIN

MAGAZINE SUBSCRIPTION

SUBSCRIPTION 


\section{НАУКИ О ЗЕМЛЕ}

\section{EARTH AND PLANETARY SCIENCES ENVIRONMENTAL SCIENCES}

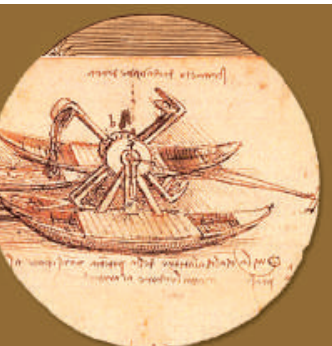

Крупные катастрофы, уюе разоривиие и продолэсающие разорять современный мир, происходят от нежелания человека считаться с законами природы,

от нежелания понять, что голод нельзя утолить, опустошая землю.

Жан ДОРСТ

\section{ОЦЕНКА ПЕРСПЕКТИВ НЕФТЕГАЗОНОСНОСТИ СЕВЕРО- ВОСТОЧНОГО БЛОКА ЮЖНО-
ХУЛЫМСКОГО МЕСТОРОЖДЕНИЯ ВОСТОЧНОГО БЛОКА ЮЖНО-
ХУЛЫМСКОГО МЕСТОРОЖДЕНИЯ}

Введение. Приоритетным направлением гидрогеохимии подземных вод является выявление первичной и вторичной миграции различных химических элементов, входящих в состав подземных вод. Последняя является функцией геологического времени и состава системы «вода-порода-органическое вещество». Данная система отражает территориальные особенности пластов коллекторов, что проявляется в формировании отдельных генетических типов подземных вод. Важной и значимой проблемой является изучение гидрогеохимических условий отдельных геологических структур Южно-Хулымского месторождения, в перспективе содержащих промышленные скопления углеводородов [1-9]. Территория Северо-Восточного блока Южно-Хулымского месторождения приурочена к северо-восточной части Западно-Сибирского артезианского бассейна.

Неокомский водоносный комплекс является самым крупным по мощности в разрезе (около 2000 м) и представлен песчано-алеврито-глинистыми породами валанжин - барремского возраста.

Учитывая тот факт, что неокомский комплекс имеет мощные глинистые разделы, а также различную природу накопления нижней и верхней частей разреза, их характеристика приведена раздельно.

Верхняя часть неокомского водоносного комплекса представлена чередованием алевролитов, глин и песчаников, к которым приурочены продуктивные пласты группы MX малохетской свиты. Общая мощность этой свиты в пределах месторождения изменяется от 2 до 50 м. Проницаемые пласты комплекса характеризуются высокими коллекторскими свойствами: пористость 16-20\%, проницаемость 90-150×10-15 мкм $^{2}$ [6; 9].

Минерализация пластовых вод этой части неокомского комплекса варьирует в пределах 9,1-160,3 г/л. Данные химического и газового составов подземных вод представлены в таблице 1.

Методика и проведенные исследования. В изучаемом водоносном комплексе развиты воды преимущественно гидрокарбонатно-натриевого и реже хлоркальциевого типов с минерализацией $2-8$ г/дм³ гидрокарбонатного или хлоридно-гидрокарбонатного натриевого состава, содержание сульфатов не превышает 50-150 мг/дм³. Состав щелочных вод отличается высо-

\footnotetext{
${ }^{1}$ Северо-Кавказский горно-металлургический институт (государственный технологический университет), 362021, г. Владикавказ, Россия,

${ }^{2}$ Астраханский государственный технический университет, 414056, г. Астрахань, Россия
}

'Босиков И.И.,

${ }^{1}$ Клюев Р.В.,

${ }^{2}$ Егорова Е.В.
УДК: 622.279.7

DOI: 10.21177/1998-4502-2019-

11-1-7-14

Рассмотрена система, в которой исследуются территориальные особенности пластов коллекторов, что нии отдельных генетических типов подземных вод. Актуальной проблемой является изучение гидрогеохимических условий отдельных геологических структур ЮжноХулымского месторождения, в перспективе содержащих промышленные скопления углеводородов.

Исследования направлены на изучение гидрогеохимических показателей нефтеносного пласта коллектора MZ-125 с целью оценки перспектив нефтегазоносности СевероВосточного блока Южно-Хулымского месторождения.

КЛЮЧЕВЫЕ СЛОВА:

месторождение, геохимия подземных вод, осадочный бассейн, скопление углеводородов, пласт коллектор, гидрогеохимических условий, нефрть и газ. проявляется в формирова- 
Состав подземных вод / Groundwater composition

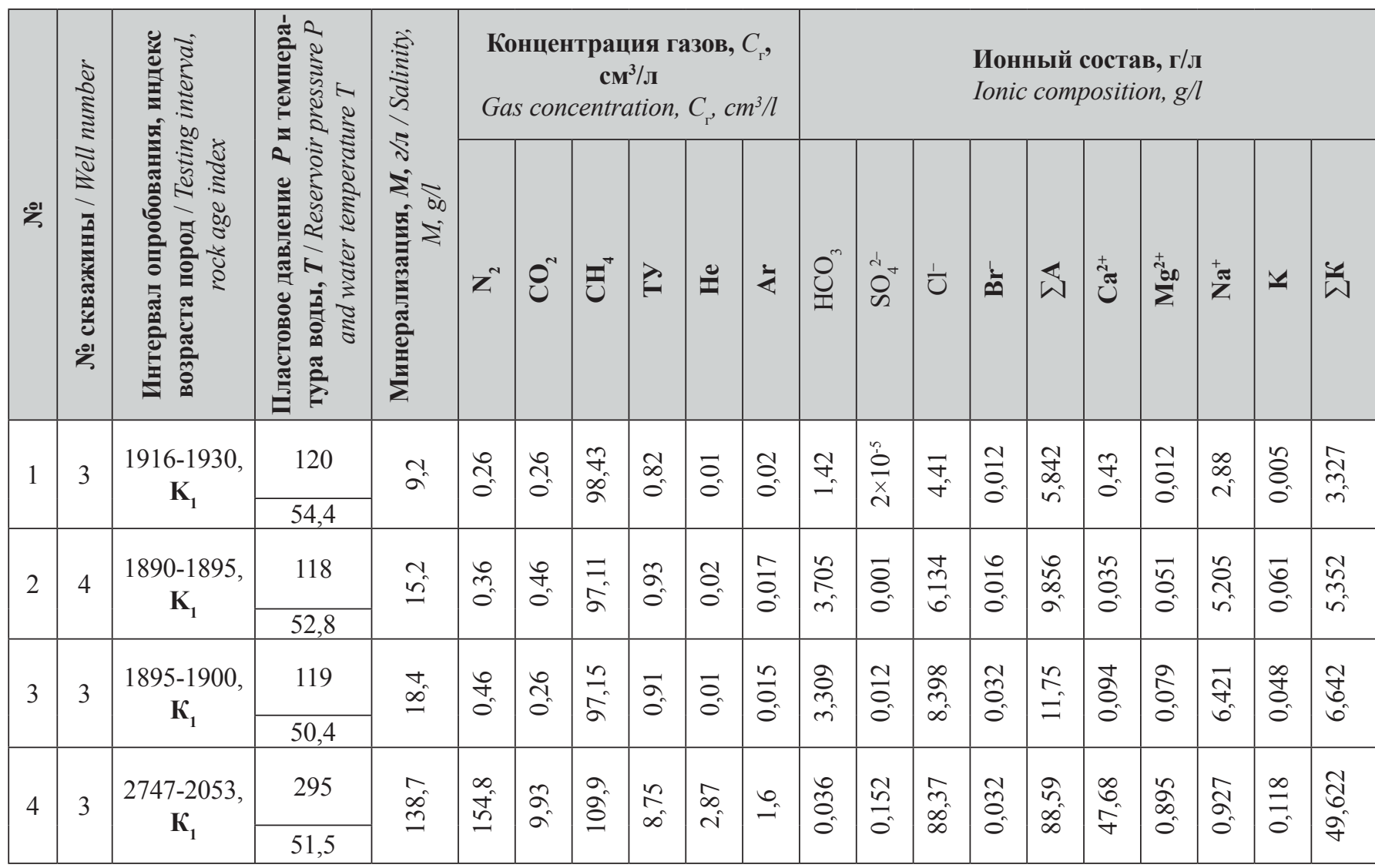

кими концентрациями гидрокарбонатов (до 1200-3600 мг/дм³). Микрокомпоненты содержатся в количестве, мг/дм³ : йод 1-20; бром 20-40; бор 10-14; аммоний $30-45$. Коэффициент $r(\mathrm{Na} / \mathrm{Cl})=0,3-2,6$. Наибольшее количество гидрокарбоната-иона отмечается в водах, приближенных к залежи нефти Южно-Хулымского месторождения [10-19].

В сводовой части структуры воды гидрокарбонатно-хлоридного натриевого состава (гидрокарбонатно-натриевый тип) мало минерализованы (2-20 г/ дм³ $^{3}$. В глубине структуры - воды хлоридные натриевые хлоркальциевого типа, имеют минерализацию до 140 г/дм ${ }^{3}$.

Газонасыщенность подземных вод изменяется незакономерно по разрезу и площади мегавала: в пределах 0,9-3,6 л/л; Водорастворенные газы (ВРГ) комплекса - метанового состава, с содержанием метана в среднем 85-90\%. В составе ВРГ доля гомологов метана довольно высокая (в среднем 2-5\%), по всему верхненеокомскому гидрогеологическому комплексу их содержание иногда достигает 20-25\%. Содержание азота не превышает 7 , диоксида углерода $-0,5$, гелия и аргона $-0,05$ и водорода $0,4 \%$. На рисунке представлено графическое изображение газового состава [18-21].

Из графика следует, что практически все пробы представлены двумя типами вод. Первая группа (ск. № $35,38,40)$ приурочена к вершине диаграммы с максимальным содержанием $\mathrm{CH}_{4}+\mathrm{T}$. Одна проба (скв. № 36) показала равновесное содержание между двумя вершинами $\mathrm{N}_{2}+\mathrm{He}+\mathrm{Ar}$ и $\mathrm{CH}_{4}+\mathrm{TУ}$.

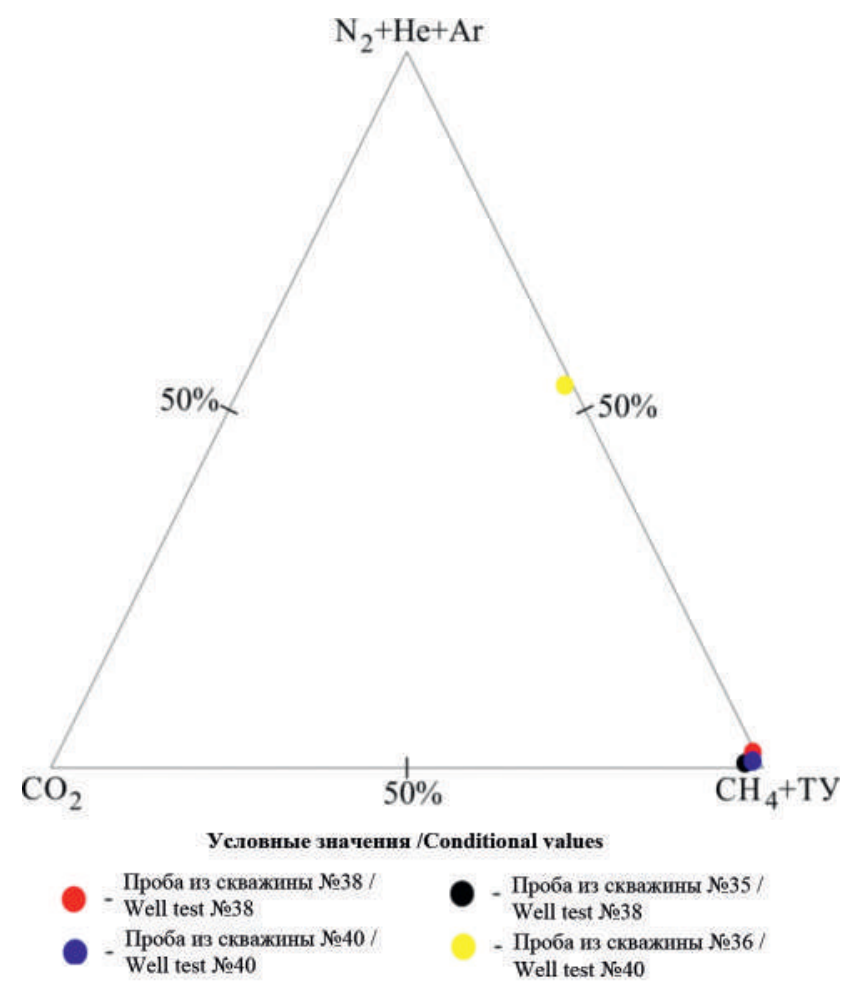

График-треугольник газового состава вод по всем скважинам

Graph-triangle of the gas composition of water in all wells 
Нефтепоисковые гидрогеологические критерии. Разнообразие литологических, структурно-тектонических и физико-химических условий в глубокозалегающих комплексах седиментационных бассейнов платформенного, предгорного, межгорного и прибрежно-шельфового типов контролирует гидрогеологические особенности формирования, сохранения и разрушения нефтегазовых залежей, генетически связанные с ними геохимические типы подземных вод и газов, соотношения между отдельными компонентами флюидальной системы и пр. Все это в свою очередь определяет выбор показателей и критериев поисков месторождений нефти и газа [5-12].

Одними из наиболее информативных нефтегазо- поисковых гидрогеологических критериев являются газо-гидрогеохимические и гидрогеохимические критерии нефтегазоносности.

Газо-гидрогеохимические критерии. Важное значение при нефте-газопоисковых работах имеют углеводородные газы, которые нередко непосредственно связаны с залежами нефти и газа. Однако и другие газы, присутствующие в залежах в незначительных концентрациях и эмигрирующие из них в воды, могут дать ценную поисковую информацию.

При оценке региональной и локальной нефтегазоносности обычно применяют следующие показатели газовой группы: общая газонасыщенность и упругость газов подземных вод, коэффициент насыщения

Таблица 2 / Table 2

Газовый состав подземных вод / Groundwater gas composition

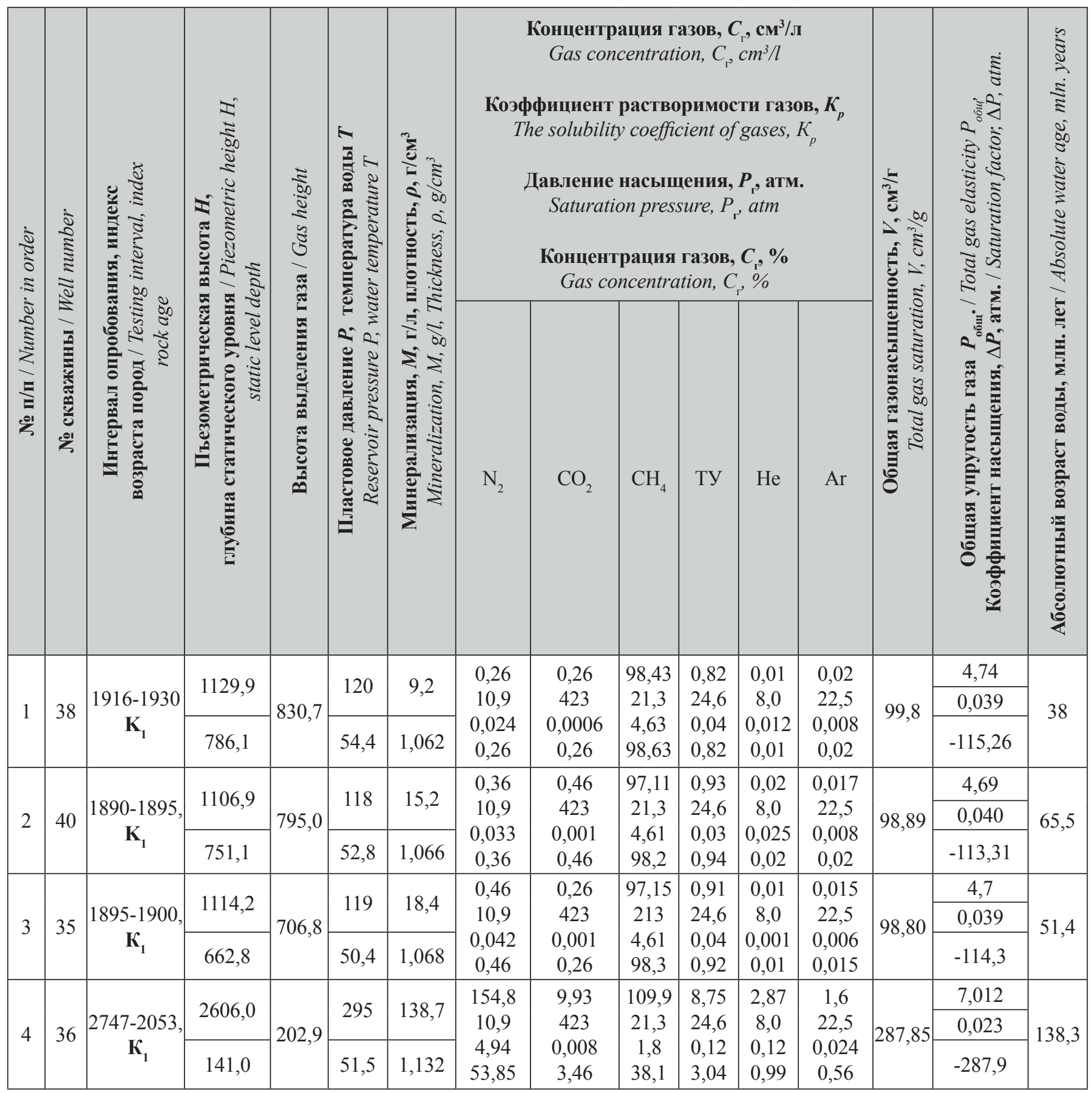


Генетические коэффициенты / Genetic factors

\begin{tabular}{|c|c|c|c|c|c|}
\hline $\begin{array}{c}\text { № проб / } \\
\text { № sampling }\end{array}$ & $\boldsymbol{r N a / r \mathbf { C l }}$ & $(\boldsymbol{r} \mathbf{C l}-\boldsymbol{r N a}) / \boldsymbol{r M g}$ & $\boldsymbol{r M g} / \boldsymbol{r} \mathbf{C a}$ & $\boldsymbol{r} \mathbf{S O}_{4} \cdot \mathbf{1 0 0} \% / \boldsymbol{r} \mathbf{C l}$ & $\mathbf{C l} / \mathbf{B r}$ \\
\hline 38 & 1,00728 & $-1,0071$ & 0,0419 & 0,000321 & 851,818 \\
\hline 40 & 1,3088 & $-12,718$ & 2,404 & 0,015 & 873,654 \\
\hline 35 & 1,179 & $-6,533$ & 1,385 & 0,105 & 598,056 \\
\hline 36 & 0,016 & 33,312 & 0,0309 & 1,829 & 6293,26 \\
\hline
\end{tabular}

Классификация подземных вод / Groundwater classification

Таблица 4 / Table 4

\begin{tabular}{|c|c|c|c|}
\hline $\begin{array}{c}\text { № сква- } \\
\text { жины } \\
\text { Well } \\
\text { number }\end{array}$ & $\begin{array}{l}\text { Классификация Алекина-Посохова } \\
\text { Classification Alekina-Posokhova }\end{array}$ & $\begin{array}{l}\text { Классификация Сулина } \\
\text { Classification Sulina }\end{array}$ & $\begin{array}{c}\text { Специфическая соль } \\
\text { Specific salt }\end{array}$ \\
\hline P8 & $\begin{array}{c}r \mathrm{Cl}<r \mathrm{Na}, r \mathrm{HCO}_{3}>r \mathrm{Ca}+r \mathrm{Mg} \rightarrow \\
\text { I тип / type }\end{array}$ & $\begin{array}{c}\text { Гидрокарбонатно-натриевый тип } \\
\text { Hydrocarbonate sodium type }\end{array}$ & $\mathrm{NaHCO}_{3}^{-}$ \\
\hline P14 & $\begin{array}{c}r \mathrm{Cl}<r \mathrm{Na}, r \mathrm{HCO}_{3}>r \mathrm{Ca}+r \mathrm{Mg} \rightarrow \\
\mathrm{I} \text { тип / type }\end{array}$ & $\begin{array}{c}\text { Гидрокарбонатно-натриевый тип } \\
\text { Hydrocarbonate sodium type }\end{array}$ & $\mathrm{NaHCO}_{3}{ }^{-}$ \\
\hline P5 & $\begin{array}{c}r \mathrm{Cl}<r \mathrm{Na}, r \mathrm{HCO}_{3}>r \mathrm{Ca}+r \mathrm{Mg} \rightarrow \\
\mathrm{I} \text { тип / type } \\
\end{array}$ & $\begin{array}{c}\text { Гидрокарбонатно-натриевый тип } \\
\text { Hydrocarbonate sodium type }\end{array}$ & $\mathrm{NaHCO}_{3}{ }^{-}$ \\
\hline P6 & $\begin{array}{c}r \mathrm{Cl}>r \mathrm{Na}+r \mathrm{Mg} \rightarrow \\
\text { I тип / type }\end{array}$ & $\begin{array}{c}\text { Хлор-кальциевый тип } \\
\text { Chlorine-calcium type }\end{array}$ & $\mathrm{CaCl}_{2}{ }^{-}$ \\
\hline
\end{tabular}

воды газом, содержание в водорастворенных газах метана, тяжелых УВ (предельные и непредельные УВ), азота, диоксида углерода, сероводорода, водорода, кислорода, гелия и аргона [18-21].

Были проанализированы результаты газового состава подземных вод пород коллекторов Южно-Хулымского месторождения по данным поискового и структурного бурения [16].

Произведен расчет общей газонасыщенности, относительной концентрации газов, давления насыщения, общей упругости газов, абсолютного возраста подземных вод. Результаты представлены в табл. 2.

Результаты исследований. Проанализировав полученные газовые показатели, сделаны следующие выводы. Если давление воды в пласте $P$ в больше упругости растворенных газов $P_{\text {г }}$ т.е. $K_{H}<1$, то весь газ будет находиться в растворенном состоянии и вода способна к дополнительному растворению газа. В насыщенных (равновесных) системах $P_{\text {г }}=P_{\text {в }}$ В пересыщенных газоводных растворах, когда $P_{\text {г }}>P_{\text {в }}$, часть газа способна выделиться из воды в свободное состояние и тогда все ловушки будут содержать залежи газа в виде газовой шапки над пластовой водой или нефтью. Таким образом, в залежи произойдет дифференциация флюидов по их плотности. Поэтому величина отношения $P_{\Gamma} / P_{\text {в }}$ имеет большое значение как показатель перспективности района в отношении обнаружения в нем газовых или газонефтяных залежей. Это - прямой признак наличия залежей газа [10-17].

Так как $K_{\text {н }}<1$, газ в пласте в свободное со- стояние выделяться не будет, газовая залежь не образуется. По генетическому признаку газы из проб скважин (№P8, №P14, №Р5 и №Р6) отчетливо подразделяются на группы: биохимическую $\left(\mathrm{CH}_{4}, \mathrm{CO}_{2}, \mathrm{~N}_{2}, \mathrm{TУ}\right)$; радиоактивную (Hе); воздушную (Ar). Газовый состав подземных вод позволяет предварительно оценить фазовое состояние углеводородов. Так, характер залежи (газ, газоконденсат, нефть) определяется по содержанию ТУ: до 2\% - газовые месторождения, до 5\% - газоконденсатные, до $10 \%$ - нефтяные [16].

Исходя из выполненного исследования по скважинам №Р8 и № P14 содержание ТУ= 11-13 об.\%, следовательно, залежь северного блока является нефтяной, а пробы № 35 и 36 с содержанием ТУ $=<1$ об. \%, это может говорить о будущих перспективах выхода газа в свободную фазу.

До последнего времени основным методом оценки абсолютного возраста древних подземных вод был метод инертных газов, требующий определения содержания водорастворенных радиогенного гелия и атмогенного аргона. Поскольку гелий является продуктом геологически длительного процесса распада радиоактивных элементов, содержащихся в горных породах, его содержание в подземных водах и газах определяется временем нахождения подземных вод в породе [16-21].

Исходя из анализа Савченко [16] следует, что рассолы и вмещающие породы сингенетичны. Таким образом, их возраст составляет более 65 млн. лет. Но также на Северо-Восточном блоке в 
скважине №Р6 подземные воды оказались в двое старше водовмещающих пород и относятся к эпигенетичным.

Подземные воды, взятые из скважины Р6 с минерализацией 138,7 г/л, относятся к крепким рассолам, а воды Северной и Восточной части месторождения с минерализацией 9,2; 15,2; 18,4 г/л относятся к слабосоленым.

Гидро-геохимические критерии. Для нефтегазопоисковых целей использовали следующие показатели соленого состава вод: тип и характер вод общей минерализации, коэффициенты метаморфизации вод, сульфатность, содержание микроэлементов (аммонии, йода, брома, бора и др.), редких и рассеянных элементов (стронции, ванадия, никеля, меди, молибдена и др.).

Были проанализированы результаты химического состава подземных вод пород коллекторов Северо-Восточного блока Южно-Хулымского месторождения по данным поискового и структурного бурения. Определены генетические коэффициенты, элементарный состав, тип рассолов [19].

Расчет генетических коэффициентов проводили по ранее использованной методике: $r \mathrm{Na} / r \mathrm{Cl}$, $r \mathrm{Cl}-r \mathrm{Na} / r \mathrm{Mg}, \mathrm{Cl} / \mathrm{Br}, r \mathrm{Mg} / r \mathrm{Ca}, r \mathrm{SO}_{4} \times 100 / r \mathrm{Cl}$. Полученные результаты приведены в табл. 3 .

Гипотетический пересчет из ионной в солевую форму использовался при обработке и систематизации химических анализов подземных вод, что помогло лучше разобраться в их химических свойствах, формировании и происхождении. Для этого применяли правило Р.Фрезениуса, которое учитывает растворимость солей [16].

Для определения геохимического типа рассолов по классификациям Алекина-Посохова и Сулина использовали ионные соотношения: $r \mathrm{Cl}>r \mathrm{Na}, r \mathrm{Cl}>$ $r \mathrm{Na}+r \mathrm{Mg}$ и $r \mathrm{HCO}_{3}>r \mathrm{Ca}+r \mathrm{Mg}$

Заключение. Анализ полученных результатов представлен отдельно для Северного и Северо-Восточного блоков (скв. № P5, Р8, Р14) и Восточного блока Южно-Хулымского месторождения (скв. № Р6).

Скважины № P8, P14, Р5. Данные рассолы по составу являются хлоридными натриевыми $(\mathrm{Cl}-$ $84,2 \%, \mathrm{Na}-84,7 \%)$, поскольку в солевом составе доминирующую роль играют соли: $(\mathrm{NaCl}-84,17$ $\left.\%, \mathrm{Ca}\left(\mathrm{HCO}_{3}\right)_{2}-14,5 \%, \mathrm{Mg}\left(\mathrm{HCO}_{3}\right)_{2}-0,67 \%\right)$. Согласно классификации Посохова [16] они относятся к I типу (гидрокарбонатно-натриевого, или содового состава) с минерализацией 9,2-18,4 г/л. По данным Попова В.Г. [1; 16] они довольно широко распространены в молодых нефтегазоносных бассейнах, чехлы которых сложены мезозойско-кайнозойскими терригенными формациями нормальных морских и опресненных.

В хлоридно-натриевых водах всегда наблюдает- ся прямая связь между $\mathrm{HCO}_{3}^{-}$и $\mathrm{CO}_{2}$. Главным источником $\mathrm{HCO}_{3}^{-}$является глубинная углекислота $\left(\mathrm{CO}_{2}+\mathrm{H}_{2} \mathrm{O}=\mathrm{H}^{+}+\mathrm{HCO}_{3}^{-}\right)$, внедряющаяся в водоносные комплексы чехла из фундамента киммерийских и альпийских структур, где она генерируется в результате термометаморфизма карбонатных пород $\left(\mathrm{CaCO}_{3}+\mathrm{H}_{2} \mathrm{O}=\mathrm{CaOH}^{+}+\mathrm{OH}^{-}+\mathrm{CO}_{2}\right.$, при $\left.\mathrm{T}>75-125^{\circ} \mathrm{C}\right)$. При этом повышается агрессивность вод к карбонатному и алюмосиликатному веществу, что вызывает поступление в раствор ионов кальция, натрия и магния и, как возможное следствие, - активизацию обменно-адсорбционных взаимодействий.

Среди процессов, контролирующих поступление и накопление в подземных водах гидрокарбонатов натрия, первостепенное значение имеют [4]:

$$
\begin{gathered}
\mathrm{CaCO}_{3}+\mathrm{CO}_{2}+\mathrm{H}_{2} \mathrm{O}=\mathrm{Ca}^{2+}+2 \mathrm{HCO}_{3}^{-}, \\
\mathrm{Ca}\left(\mathrm{HCO}_{3}\right)_{2}(\text { вода })+2 \mathrm{Na}^{+}(\text {адс. }) \Leftrightarrow 2 \mathrm{NaHCO}_{3}(\text { вода })+ \\
\left.+\mathrm{Ca}^{2+} \text { (адс. }\right), \\
2 \mathrm{NaAlSi}_{3} \mathrm{O}_{8} \text { (альбит) }+2 \mathrm{CO}_{2}+11 \mathrm{H}_{2} \mathrm{O} \rightarrow \\
\mathrm{Al}_{2} \mathrm{Si}_{2} \mathrm{O}_{5}(\mathrm{OH})_{4}(\text { каолинит })+2 \mathrm{Na}^{+}+ \\
+2 \mathrm{HCO}_{3}^{-}+4 \mathrm{H}_{4} \mathrm{SiO}_{4} .
\end{gathered}
$$

В результате процессов обменной адсорбции и/или гидролиза натриевых полевых шпатов в растворе появляются гидрокарбонаты натрия и талассогенная хлоридная натриевая вода хлор-магниевого типа трансформируется в хлоридно-гидрокарбонатную натриевую содового типа.

Судя по глубине залегания, составу воды и генетическому коэффициенту $\mathrm{Cl} / \mathrm{Br}=851,818$ и величине минерализации, вода - седиментогенная, опресненная речными водами.

Установлено, что содовый состав вод всегда парагенетически ассоциируется с газами биохимического и химического происхождения: $\mathrm{CO}_{2}, \mathrm{CH}_{4}, \mathrm{H}_{2} \mathrm{~S}$ и др.

Скважина № P6. Данный рассол по составу является хлоридным кальциево-натриевым. В солевом составе доминирующую роль играют соли: $\mathrm{NaCl}$, $\mathrm{CaCl}_{2}$, а подчиненное значение имеет соль $\mathrm{MgCl}_{2}$. Данный рассол имеет минерализацию 140,92 г/л и относится к крепким рассолам, по отношению к соленосным породам - является надсолевым рассолом. Хлоридные кальциево-натриевые рассолы являются основным геохимическим типом вод комплексов нефтегазоносных бассейнов. Эти рассолы имеют высокую минерализацию (140,92 г/л) и метаморфизацию $(r \mathrm{Na} / \mathrm{rCl}=0,31)$, с содержанием брома 0,95 г/л $(\mathrm{Cl} / \mathrm{Br} 414,37)$. Эти рассолы образовались в результате конвективного погружения высокоминерализованных тяжелых маточных хлор-магниевых рассолов из поверхностных солеродных палеоводоемов в вышележащие породы, насыщенные менее минерализованными, а следовательно, менее плотными водами. Поскольку рассолы поступили в уже сформировавшиеся породы на эпигенетической стадии их преобразования, эти рассолы принято называть седиментоген- 
но-эпигенетическими. Они по сравнению с породами имеют более молодой возраст. Наличие в рассоле соли $\mathrm{CaCl}_{2}$ связано с метаморфизацией в известняках. Особое значение при этом имеет процесс доломитизации:

$$
\begin{aligned}
& 2 \mathrm{CaCO}_{3} \text { (известняк) }+\mathrm{MgCl}_{2} \text { (рассол) } \Leftrightarrow \\
\Leftrightarrow & \mathrm{CaCO}_{3} \times \mathrm{MgCO}_{3} \text { (доломит) }+\mathrm{CaCl}_{2} \text { (рассол). }
\end{aligned}
$$

Данные типы рассолов характерны для нефтяных месторождений. Так как хлор-кальциевый и гидрокарбонатный типы подземных вод ассоциируют с углеводородами, Северный блок, находящийся на более высоких гипсометрических отметках, может представлять перспективную площадь, которая является своеобразной ловушкой на пути миграции подземных вод, характерных для нефти и газа Восточного и Северо-Восточного блоков. В связи с этим поиск и оценка данной территории оправданны, Северо-Восточный блок Южно-Хулымского месторождения является первоочередным и перспективным объектом, возможно содержащим промышленное скопление углеводородов.

\section{ЛИТЕРАТУРА:}

1. Гутман И. С. Методы подсчёта запасов и оценки ресурсов нефти и газа: Учебник для вузов. М.: ООО «Издательский дом Недра», 2017. 366 с.

2. Дулаева Е. Н., Шакиров Р. И. Анализ зон разуплотнений, выделенных различными методами, в карбонатных коллекторах башкирско-серпуховских отложений / Геология, разработка нефтяных и нефтегазовых месторождений: Тезисы докладов. Бугульма. 2013.

3. Кашников Ю. А., Ашихмин С. Г. Механика горных пород при разработке месторождений углеводородного сырья. М.: Недра, 2007. 467 с.

4. Шпильман В. И., Цзинь Чжи Цзюнь. Закон распределения выявленных и невыявленных залежей нефти и газа по величине запасов // Геология нефти и газа. 1993. N 11. C. $177-180$.

5. Егорова Е. В., Клюев Р. В., Босиков И. И., Цидаев Б. C. Evaluation of use of effective technologies for increasing sustainable development of natural and technical system of oil and gas complex // Устойчивое развитие горных территорий. 2018. Т. 10. N 3 (37). С. 392-403.

6. Босиков И. И., Клюев Р. В. Разработка методов и алгоритмов повышения эффективности функционирования промышленно-технической системы. Монография. Владикавказ: Северо-Кавказский горно-металлургический институт (государственный технологический университет). Изд-во «Терек», 2018. 237 с.

7. Паффенгольц К. Н. Геологический словарь: в 2-х томах / Отв. ред. Паффенгольц К. Н. 2-е издание, исправленное. Москва: Недра, 1978. 456 с.

8. Петров А. И., Шеин В. С. О необходимости учета современной геодинамики при оценке и пересчете промышленных запасов нефти и газа // Геология нефти и газа. 2010. N 5. C. 47-58.

9. Bosikov I. I., Klyuev R. V, Revazov V. Ch. Performance evaluation of functioning of natural-industrial system of mining-processing complex with help of analytical and mathematical models // IOP Conference Series: Materials Science and Engineering, 2018. 2018 IOP Conf. Ser.: Mater. Sci. Eng. 327022013.
10. Тимурзиев А. И. Технология прогнозирования трещиноватости на основе трехмерной -60.

11. Макарова О. М., Коробова Н. И. Латеральная изменчивость баженовской свиты на северо-востоке Сургутского свода / В сборнике «Новые идеи в геологии нефти и газа-2015». М.: Московский государственный университет имени М. В. Ломоносова, 2015. С. 299-301.

12. Санникова И. А., Кирюхина Т. А. Моделирование процессов образования углеводородов в Коротаихинской впадине Тимано-Печорского бассейна / В сборнике «Новые идеи в геологии нефти и газа-2015». М.: Московский государственный университет имени М. В. Ломоносова, 2015. C. 268-272.

13. Галкин В. И., Кочнева О. Е. Геология и геохимия нефти и газа. Пермь: Пермский национальный исследовательский политехнический университет, 2017. С. 181.

14. Бембель С. Р. Геология и картирование особенностей строения месторождений нефти и газа Западной Сибири. Тюмень: Тюменский индустриальный университет, 2016. С. 215.

15. Абрамов В. Ю. Нефтепромысловая геология и подсчёт запасов нефти и газа. Москва: РУДН, 2017. С. 76.

16. Геология и геохимия нефти и газа / О. К. Баженова и др. М.: Издательство МГУ, 2012. 432 с.

17. Геология нефти и газа. Учебник / В. Ю. Керимов и др. М.: Academia, 2015. 288 с.

18. Норман Дж. Хайн. Геология, разведка, бурение и добыча нефти. М.: Олимп-Бизнес, 2008. 752 с.

19. Tang G.-Q. \& Morrow, N. R. Influence of brine composition and fines migration on crude oil/brine/rock interactions and oil recovery // Journal of Petroleum Science and Engineering. 1999. 111. No. 24. P. 99.

20. Morrow N., Buckley J. Improved oil recovery by LowSalinity Water flooding. SPE 129421.

21. Wilcox R., Fisk J. Test show shale behavior, aid well planning // Oil and Gas J. 1983. 12/IX. V. 81, no. 37. 


\section{СВЕДЕНИЯ ОБ АВТОРАХ / Information about authors:}

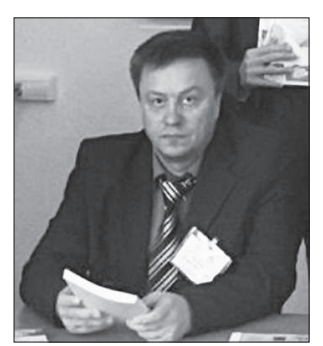

БОСИКОВ Игорь Иванович -

кандидат технических наук, доцент, член-корреспондент.

Северо-Кавказский горно-металлургический институт (государственный технологический университет).

362021, Владикавказ, Россия, igor.boss.777@mail.ru

Igor I. BOSIKOV - Candidate of Technical Sciences, Associate Professor, corresponding member.

North-Caucasian Institute of Mining and Metallurgy (State Technological University).

362021, Vladikavkaz, Russia, igor.boss.777@mail.ru

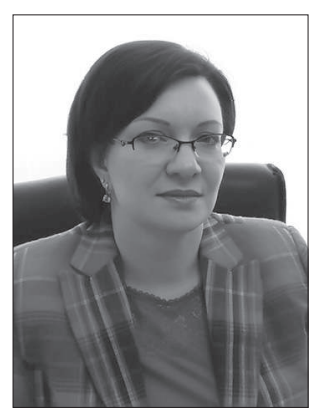

ЕГОРОВА Елена Валерьевна кандидат технических наук, доцент; директор Прикаспийского образовательного центра нефтегазовых технологий Института нефти и газа Астраханского государственного технического университета.

414056, Астрахань, Россия, egorova_ev@list.ru

Elena V. EGOROVA - Candidate of Technical Sciences, Associate Professor; Director of the Caspian Educational Center of Oil and Gas Technologies of the Institute of oil and gas of Astrakhan State Technical University.

414056,Astrakhan,Russia,egorova_ev@list.ru

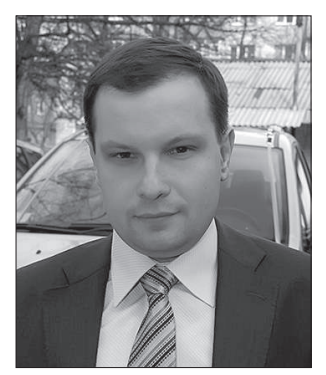

КЛЮЕВ Роман Владимирович - доктор технических наук, профессор.

Северо-Кавказский горно-металлургический институт (государственный технологический университет), 362021, Владикавказ, Россия.

Тел.: 8(8672)-40-73-71 (раб.);

8(918)707-39-25 (моб.);

kluev-roman@rambler.ru

Roman VI. KLYUEV - Doctor of Technical Sciences, Professor. North-Caucasian Institute of Mining and Metallurgy (State Technological University), 362021, Vladikavkaz, Russia.

Ph.:8(8672)-40-73-71 (slave.); 8(918) 707-39-25 (mob.); kluev-roman@rambler.ru

\title{
ASSESSMENT OF OIL AND GAS POTENTIAL PROSPECTS OF THE NORTH EASTERN UNIT OF THE SOUTH KHULYM DEPOSIT
}

\author{
${ }^{1}$ I. I. Bosikov, * \\ ${ }^{1}$ R. V. Klyuev, \\ ${ }^{2}$ E. V. Egorova \\ ${ }^{1}$ North-Caucasian Institute of Mining and Metallurgy (State Technological University), 362021, Vladikavkaz, Russia, \\ igor.boss.777@mail.ru \\ ${ }^{2}$ Caspian Educational Center of Oil and Gas Technologies of the Institute of Oil and Gas of Astrakhan State Technical \\ University, 414056, Astrakhan, Russia
}

DOI: $10.21177 / 1998-4502-2019-11-1-7-14$

The article considers a system in which the territorial features of reservoir layers are investigated, which is manifested in the formation of certain genetic types of groundwater. The actual problem is the study of the hydrogeochemical conditions of individual geological structures of the Yuzhno-Khulymsky field, in the future containing industrial accumulations of hydrocarbons.

The purpose of research. The studies are aimed at studying the hydrogeochemical indicators of the reservoir oil reservoir MZ-125 in order to assess the oil and gas potential of the North-Eastern block of the South Khulym field.

Tasks of research. To achieve the goal, it is necessary to solve the following tasks:

- processing and systematization of data on the geochemistry of groundwater of the North-Eastern block of the Yuzhno-Khulymsky field;

- hydrogeochemical study of the South Khulym sedimen- tary basin, zonality and genetic characteristics of groundwater, the degree of their metamorphization;

- analysis of the gas composition of groundwater reservoir rocks of the North-Eastern block of the South-Khulymsky field;

- division of groundwater into genetic types;

- calculation of various coefficients of genetic indicators of groundwater.

Research results. For oil and gas exploration purposes, the following indicators of the salt composition of water were used: type of water and nature of total mineralization, water metamorphism coefficients, sulfate content, trace element content (ammonium, iodine, bromine, boron, etc.), rare and trace elements (strontium, vanadium, nickel, copper, molybdenum, etc.). The results of the chemical composition of groundwater in reservoir rocks of the Northeastern block of the Yuzhno-Khulymskoe field were analyzed according to the data of exploratory and structural drilling. 
The genetic factors, elemental composition, type of brines were determined. The presence of $\mathrm{CaCl}_{2}$ salt in brine is associated with metamorphization in limestone. The process of dolomitization is of particular importance: $2 \mathrm{CaCO}_{3}$ (limestone) $+\mathrm{MgCl}_{2}$ (brine) $=\mathrm{CaCO}_{3} \times \mathrm{MgCO}_{3}$ (dolomite) $+\mathrm{CaCl}_{2}$ (brine). These types of brines are characteristic of oil fields. Since chlorine-calcium and bicarbonate types of groundwater are associated with hydrocarbons, the Northern block located at higher hypsometric elevations may represent a promising area, which is a kind of trap on the migration route of groundwater characteristic of the oil and gas of the Eastern and North-Eastern blocks. In this regard, the search and assessment of this area is justified, the Northeast bloc is the primary and promising object possibly containing industrial accumulation of hydrocarbons.

Keywords: field, geochemistry of groundwater, sedimentary basin, accumulation of hydrocarbons, reservoir reservoir, hydrogeochemical conditions, oil and gas.

\section{References}

1. Gutman I.S. Methods for calculating reserves and assessing oil and gas resources: A textbook for universities. Moscow, Publishing House Nedra LLC, 2017, 366 p. (In Russian).

2. Dulaeva E.N., Shakirov R.I. Analysis of decompression zones identified by different methods in carbonate reservoirs of the Bashkir-Serpukhov deposits. Geology, Development of Oil and Gas Fields, Abstracts of the report, Bugulma, 2013, pp. 33-44.(In Russian).

3. Kashnikov Yu.A., Ashikhmin S.G. Rock mechanics in the development of hydrocarbon deposits. Moscow, Nedra, 2007, 467 p. (In Russian).

4. Spielman VI, Jin Zhi Jun. The distribution law of the discovered and undetected deposits of oil and gas in terms of reserves. Geology of oil and gas, 1993, No 11, pp. 177-180. (In Russian).

5. Yegorova E.V., Klyuev R.V., Bosikov I.I., Tsidaev B.S. Oil and gas complex. Sustainable Development of Mountain Territories, 2018, v.10. no 3 (37), pp. 392-403.

6. Bosikov I.I., Klyuev R.V. Development of methods and algorithms for improving the efficiency of the industrialtechnical system. Monograph. Vladikavkaz, North Caucasus Mining and Metallurgical Institute (State Technological University), Terek Publishing House, 2018, 237 p. (In Russian).

7. Paffenholz K. Geological dictionary: in 2 volumes. Ed. Paffenholz K. 2nd edition, revised. Moscow, Nedra, 1978, $456 \mathrm{p}$.

8. Petrov A.I., Shein V.S. On the need to take into account modern geodynamics in assessing and recalculating indus- trial reserves of oil and gas. Geology of Oil and Gas, 2010, no 5, pp. 47-58.(In Russian).

9. Bosikov I. I., Klyuev R. V, Revazov V. Ch., Performance evaluation of functioning of natural-industrial system of mining-processing complex with help of analytical and mathematical models. IOP Conference Series: Materials Science and Engineering, 2018, 327022013.

10. Timurziev A.I. Fracture prediction technology based on a three-dimensional geomechanical and kinematic model of a fractured reservoir. Geophysics, 2008, no. 3, pp. 41-60. (In Russian).

11. Makarova O.M., Korobova N.I. Lateral variability of the Bazhenov formation in the north-east of the Surgut arch. In the Collection New Ideas in Geology of Oil and Gas 2015, Moscow University Press, Moscow State University named after M.V. Lomonosov, theses, pp. 299-301.(In Russian).

12. Sannikova I.A., Kiryukhina T.A. Modeling the formation of hydrocarbons in the Korotaikhinsky depression of the Timan-Pechora basin. In the Collection New Ideas in the Geology of Oil and Gas - 2015. Moscow University Press, Moscow State University Lomonosov, pp. 268-272 (In Russian).

13. Galkin V.I., Kochneva O.E. Geology and geochemistry of oil and gas. Perm National Research Polytechnic University, Perm, 2017, p. 181. (In Russian).

14. Bembel S.R. Geology and mapping features of the structure of oil and gas fields in Western Siberia. TIU, Tyumen, 2016, p. 215. (In Russian).

15. Abramov V.Yu. Oil field geology and estimation of oil and gas reserves. RUDN, Moscow, 2017, p. 76. (In Russian).

16. Geology and geochemistry of oil and gas. OK. Bazhenov et al. Moscow, Publishing House of Moscow State University, 2012, 432 c.(In Russian).

17. Geology of oil and gas. Textbook. V.Yu. Kerimov et al. Moscow, Academia, 2015, 288 p. (In Russian).

18. Norman, J. Hayne Geology, exploration, drilling and oil extraction. Moscow, Olymp-Business, 2008, 752 c. (In Russian).

19. Tang G.-Q. \& Morrow, N.R. Influence of oil and brine / rock interactions and oil recovery. Journal of Petroleum Science and Engineering, 1999, 111, no. 24, p. 99

20. Morrow N., Buckley J. Improved oil recovery by Low-Salinity Waterflooding. SPE 129421.

21. Wilcox R., Fisk J. Test show shale behavior, aid well planning. Oil and Gas J., 1983, 12 / IX, v. 81, no. 37.

Article received 15.01.2019. 


\section{ГЕОЭКОЛОГИЧЕСКИЕ ИНДИКАТОРЫ УСТОЙЧИВОГО РАЗВИТИЯ: ПРОСТРАНСТВЕННЫЙ АНАЛИЗ}

\section{Введение}

Обеспечение высоких темпов экономического роста, которое рассматривается как одно из ключевых условий повышения благосостояния населения [1], часто влечет за собой негативные экологические последствия: загрязнение атмосферного воздуха и водных объектов, истощение природных ресурсов и т.д. Это особенно актуально для горных территорий с исторически сложившейся сырьевой специализацией экономики, поскольку горнодобывающая отрасль вносит весомый вклад в общий объем загрязнений. На многих из них ресурсная направленность хозяйственной деятельности сохраняется или даже усиливается, несмотря на обозначенные в стратегических документах сценарии, предусматривающие развитие инновационной экономики [2]. Такая ситуация характерна для большинства восточных регионов, в основе экономического развития которых по-прежнему остаются природные ресурсы [3]. Наблюдающаяся в последние годы активизация российско-китайского сотрудничества также оказывает заметное влияние на динамику развития горнодобывающей промышленности на данных территориях. Заинтересованность Китая в импорте топливно-энергетических, минерально-сырьевых и лесных ресурсов для производства продукции [4] является положительным мотивом для развития сырьевого сектора экономики, характеризующегося невысокой степенью переработки природного сырья.

Одним из приоритетных направлений в сфере обеспечения экологической безопасности, которое указано в национальном стратегическом документе - Стратегии экологической безопасности РФ на период до 2025 года [5], является внедрение инновационных и экологически чистых технологий, развитие экологически безопасных производств. В данном случае речь идет об экологической модернизации, которая представляет собой «изменения в соответствии с новейшими, современными экологическими требованиями и нормами, выполнение которых ведет к устранению проблем между человеком и окружающей средой, обществом и природой» [6].

Для оценки состояния экологической безопасности в национальной Стратегии [5] предусматривается набор индикаторов, в числе которых, например, показатель «Объем образованных отходов I класса опасности на единицу валового внутреннего продукта». Данный индикатор является частным случаем показателя «эко-интенсивность» [7-10], который, в применении к пространственным аспектам относится к числу геоэкологических характеристик качества экономического роста. Необходимость использования таких показателей для оценки устойчивости развития национальных и региональных хозяйственных систем обосновывается в работах многих российских и зарубежных исследователей [11-16].

Цель исследования - получение количественных характеристик процессов экологической модернизации хозяйственных систем регионов с помощью динамики показателей воздействия на окружающую среду. Особое внимание будет уделено анализу вклада горнодобывающей промышленности, поскольку она оказывает существенное негативное воздействие на природные среды.

Исходные данные и методы исследования. Методологический подход данного исследования основан на анализе показателей эко-интенсивности. Эко-интенсивность определяет степень негативного воздействия на окружающую среду в расчете на единицу экономического результата и позволяет

\footnotetext{
${ }^{1}$ Институт природных ресурсов, экологии и криологии СО РАН; 672002, г. Чита, Россия

*e-mail: i_zabelina@mail.ru
}

1Забелина И.А.*, 'Делюга А.В.

УДК: 504.06

DOI: 10.21171/1998-4502-2019-

$11-1-15-25$

Исследованы процессы экологической модернизации хозяйственных систем регионов с помощью динамики показателей воздействия на окружающую среду в российских регионах. Для получения количественных характеристик использован один из геоэкологических показателей качества экономического роста - индикатор «эко-интенсивность». Он определяет степень негативного воздействия на природные среды в расчете на единицу результата хозяйственной деятельности. Выявлены тенденции изменения эко-интенсивности выбросов загрязняющих веществ от стационарных источников

(в том числе и наиболее распространенных загрязнителей) в различные временные интервалы. Установлено, что в последние годы увеличилось число регионов, характеризующихся ростом удельной экологической нагрузки. Изучение динамики негативных воздействий на окружающую среду в горнодобывающей промышленности показало, что вредные выбросы в атмосферу в расчете на единицу результата хозяйственной деятельности в сфере добычи полезных ископаемых в некоторых ресурсных регионах заметно выше, чем в целом по экономике.

\section{КЛЮЧЕВЫЕ СЛОВА:}

эко-интенсивность, горнодобывающая промышленность, экологическая модернизация, негативное воздействие на окружающую среду, регионы Poccuu.

Статья поступила в редакцию 30.08.2018. 
сопоставить результаты хозяйственной деятельности с ценой, которую общество платит за эти результаты [8; 17]. Рассмотрение данного показателя в динамике позволит сделать выводы о качестве экономического роста и модернизации в эколого-экономических системах регионов. В работе использованы официальные данные Федеральной службы государственной статистики [22] (стоимостные показатели были приведены к сопоставимому виду; в качестве базового был выбран 2005 г.).

Показателем экологической нагрузки в исследовании выступает объем выбросов в атмосферу загрязняющих веществ от стационарных источников, в том числе в разрезе наиболее распространённых: твёрдые частицы, диоксид серы, оксиды азота и оксид углерода. В качестве характеристики экономической эффективности используется основной измеритель уровня экономического развития регионов - валовой региональный продукт (ВРП). Высокие значения эко-интенсивности могут свидетельствовать о том, что для получения единицы экономического результата хозяйственной системе региона требуется производить повышенные выбросы загрязняющих веществ. Рост данного показателя за рассматриваемый временной интервал рассматривается как негативная тенденция и признак либо отсутствия, либо недостаточной эффективности экологической модернизации, поскольку на каждую единицу экономического результата в текущем периоде приходится больший по сравнению с базовым периодом объем загрязняющих веществ.

В работе [18] отмечается, что кризисные явления оказывают двойственное влияние на состояние окружающей среды: с одной стороны, приводят к ухудшению экологической ситуации, а с другой - могут способствовать развитию новых возможностей в направлении решения экологических проблем. В связи с этим в данном исследовании было выделено три временных интервала:

1. 2005-2009 гг. - период устойчивого экономического роста в большинстве регионов;
2. 2009-2013 гг. - период проявления мирового финансово-экономического кризиса и посткризисного восстановления экономики;

3. 2013-2016 гг. - период кризисных явлений в экономике, вызванных одновременным действием ряда внутренних и внешних факторов [19].

Изучение показателей эко-интенсивности даёт возможность сравнивать не только регионы между собой, но и отрасли по качеству роста, который они обеспечивают. Важнейшим этапом исследования является оценка развития добывающей промышленности, которая представляет собой основу экономики многих горных территорий с исторически сложившейся сырьевой специализацией экономики. В качестве показателя, характеризующего результат хозяйственной деятельности горнодобывающих предприятий, выступает вклад в ВРП вида экономической деятельности (ВЭД) «Добыча полезных ископаемых», а в качестве показателя негативного воздействия взяты выбросы загрязняющих атмосферу веществ от стационарных источников данного ВЭД. Поскольку статистические данные по негативному воздействию на окружающую среду в отраслевом разрезе за 2013 г. отсутствуют, были рассмотрены следующие временные интервалы: 2005-2009 гг., 2009-2012 гг. и 2012-2016 гг.

Для пространственного анализа динамики количественных характеристик процессов экологической модернизации хозяйственных систем используются инструменты геоинформационных технологий.

Результаты расчетов и их обсуждение. В последние годы в РФ наблюдается тенденция снижения суммарных выбросов в атмосферу от стационарных источников, в том числе в разрезе наиболее распространенных загрязняющих веществ, исключение составляют выбросы оксидов азота (табл. 1). Однако, несмотря на наблюдающееся снижение количества выбросов в атмосферу, в окружающей среде происходит накопление загрязняющих веществ, воздействие которых она не успевает нейтрализовать [20; 21].

Выбросы загрязняющих атмосферу веществ от стационарных источников в РФ

Таблица 1 / Table 1 Trends of air pollutant emissions from stationary sources in the Russian Federation

\begin{tabular}{|c|c|c|c|c|c|}
\hline $\begin{array}{c}\text { Показатель, тыс. тонн } \\
\text { Indicator, thousand tons }\end{array}$ & $\mathbf{2 0 0 5}$ & $\mathbf{2 0 0 9}$ & $\mathbf{2 0 1 3}$ & $\mathbf{2 0 1 6}$ & $\begin{array}{c}\text { Изменение к 2005, \% } \\
\text { Change compared to 2005, \% }\end{array}$ \\
\hline $\begin{array}{c}\text { Общий объем выбросов в атмосферу от стационарных ис- } \\
\text { точников / Air pollutant emissions from stationary sources }\end{array}$ & 20425,0 & 19021,0 & 18447,0 & 17349,3 & $-15,1$ \\
\hline Выбросы твердых веществ / Solids emissions & 2802,0 & 2341,1 & 2008,5 & 1723,9 & $-38,5$ \\
\hline Выбросы диоксида серы / Sulfur dioxide emissions & 4675,0 & 4370,6 & 4173,3 & 4011,4 & $-14,2$ \\
\hline Выбросы оксидов азота / Nitrogen oxides emission & 1666,8 & 1730,5 & 1874,2 & 1830,1 & 9,8 \\
\hline Выбросы оксида углерода / Carbon monoxide emissions & 6521,2 & 5500,5 & 5350,9 & 4907,1 & $-24,8$ \\
\hline
\end{tabular}

Примечание: Таблица составлена по данным Федеральной службы государственной статистики [22].

Note: The table is compiled from data of the Federal State Statistics Service [22]. 
Очевидно, что выбросы загрязняющих веществ распределены между регионами крайне неравномерно [23]. Такая ситуация объясняется различным уровнем развития региональных хозяйственных систем, наличием на территории объектов генерации электрической и тепловой энергии, работающих на твёрдом топливе. Распределение российских регионов по различным группам, выделенным в зависимости от изменения эко-интенсивности выбросов загрязняющих веществ, показано на рис. 1, $a-c$. В период с 2005 по 2009 г. наибольший рост удельных выбросов загрязняющих веществ отмечался в трех регионах: Ненецком АО, Тамбовской и Орловской областях. Эко-интенсивность на национальном уровне уменьшилась на 18,7 \%. В таких регионах, как Республика Саха, Томская, Кемеровская, Тюменская, Псковская, Тверская, Смоленская, Курская, Воронежская, Кировская области, Республика Марий Эл, Краснодарский край и Кабардино-Балкарская Республика отмечается небольшой прирост эко-интенсивности (0,4-21,8 \%). Развитие остальных регионов характеризовалось снижением рассматриваемого показателя, наилучшие значения принадлежали Чукотскому АО и Республике Дагестан.
В период с 2009 по 2013 г. наблюдалась негативная тенденция: увеличилось число регионов, в которых эко-интенсивность выбросов в атмосферу от стационарных источников выросла: 23 против 16 регионов в предкризисный период. Существенное увеличение удельной экологической нагрузки отмечается в Республиках Адыгея, Калмыкия и Удмуртия. В основных нефтегазовых, а также в большинстве регионов Сибири и Дальнего Востока, специализирующихся на добыче полезных ископаемых, произошло снижение удельных выбросов за рассматриваемый период, что соответствует общенациональной тенденции. Вместе с тем стоит отметить, что в период с 2013 по 2016 г. в обозначенных восточных регионах отмечался рост эко-интенсивности выбросов загрязняющих атмосферу веществ, что может свидетельствовать об отсутствии, либо недостаточной эффективности экологической модернизации в региональных хозяйственных системах.

Наблюдаемая в последние годы активизация российско-китайского сотрудничества также может оказать влияние на динамику изучаемых показателей в российских регионах, имеющих общую границу с сопредельным государством и/или вовлеченных в

Таблица 2 / Table 2

Изменение эко-интенсивности выбросов загрязняющих атмосферу веществ от стационарных источников в регионах трансграничного взаимодействия и РФ

Change in the eco-intensity of air pollutant emissions from stationary sources in cross-border regions and Russian Federation

\begin{tabular}{|c|c|c|c|c|c|c|c|}
\hline \multirow[t]{2}{*}{$\begin{array}{c}\text { Регион } \\
\text { Region }\end{array}$} & \multicolumn{4}{|c|}{$\begin{array}{c}\text { Эко-интенсивность выбросов загряз- } \\
\text { няющих атмосферу веществ от стацио- } \\
\text { нарных источников, т/млн руб. } \\
\text { Eco-intensity of air pollutant emissions from } \\
\text { stationary sources, } \\
t \text { / million rubles } \\
\end{array}$} & \multicolumn{3}{|c|}{$\begin{array}{c}\text { Изменение эко-интенсивности } \\
\text { выбросов, \% } \\
\text { Change in eco-intensity of emissions, \% }\end{array}$} \\
\hline & 2005 & 2009 & 2013 & 2016 & $2005 / 2009$ & $2009 / 2013$ & $2013 / 2016$ \\
\hline $\begin{array}{c}\text { Республика Алтай } \\
\text { Republic of Altai }\end{array}$ & 1,48 & 0,99 & 0,87 & 0,61 & $-33,2$ & $-12,3$ & $-29,6$ \\
\hline $\begin{array}{r}\text { Республика Бурятия } \\
\text { Republic of Buryatia }\end{array}$ & 1,16 & 1,15 & 1,26 & 1,14 & $-0,8$ & 9,1 & $-9,6$ \\
\hline $\begin{array}{c}\text { Забайкальский край } \\
\text { Trans-Baikal Territory }\end{array}$ & 2,01 & 1,61 & 1,25 & 1,29 & $-19,7$ & $-22,4$ & 2,5 \\
\hline $\begin{array}{c}\text { Иркутская область } \\
\text { Irkutsk Region }\end{array}$ & 1,95 & 1,71 & 1,68 & 1,46 & $-12,1$ & $-1,6$ & $-13,5$ \\
\hline $\begin{array}{l}\text { Приморский край } \\
\text { Primorye Territory }\end{array}$ & 1,39 & 0,99 & 0,73 & 0,77 & $-28,6$ & $-26,3$ & 4,5 \\
\hline $\begin{array}{c}\text { Хабаровский край } \\
\text { Khabarovsk Territory }\end{array}$ & 0,90 & 0,67 & 0,58 & 0,60 & $-25,5$ & $-13,7$ & 3,2 \\
\hline $\begin{array}{c}\text { Амурская область } \\
\text { Amur Region }\end{array}$ & 1,35 & 1,30 & 1,41 & 1,44 & $-3,9$ & 8,1 & 2,6 \\
\hline $\begin{array}{c}\text { Еврейская АО } \\
\text { Jewish Autonomous Region }\end{array}$ & 1,97 & 1,11 & 1,36 & 1,11 & $-43,9$ & 23,0 & $-18,1$ \\
\hline $\begin{array}{c}\text { Российская Федерация } \\
\text { Russian Federation }\end{array}$ & 1,13 & 0,92 & 0,77 & 0,72 & $-18,7$ & $-16,2$ & $-7,3$ \\
\hline
\end{tabular}

Примечание: Рассчитано авторами на основе данных Федеральной службы государственной статистики [22].

Note: Calculated by authors on the basis of data of the Federal State Statistics Service [22]. 
трансграничное взаимодействие. В табл. 2 приведены абсолютные значения эко-интенсивности выбросов загрязняющих атмосферу веществ в этих регионах и в целом по стране, а также их изменение. Сравнительный анализ показывает, что в большинстве из них на 1 млн рублей ВРП приходится больше выбросов, чем в среднем по РФ. Однако динамика исследуемого индикатора показала, что в регионах трансграничного взаимодействия не отмечается согласованной тенденции в отношении изменения эко-интенсивности, как на национальном уровне. Следовательно, экологизация хозяйственной деятельности здесь состоялась в недостаточной степени. В работе [24] отмечается, что в приграничных регионах Востока России имеют ме- сто примеры использования компаниями с участием китайского капитала устаревшего оборудования, опасных для окружающей среды технологий и практик, что приводит к негативным экологическим последствиям. На протяжении всех рассматриваемых периодов позитивные сдвиги отмечены только в Республике Алтай и Иркутской области.

Деятельность по добыче и переработке природных ресурсов, как и по производству тепловой и электрической энергии, оказывает существенное негативное воздействие на природные среды. В отдельных природно-ресурсных регионах эко-интенсивность выбросов, рассчитанная для ВЭД «Добыча полезных ископаемых», оказалась заметно выше, чем для экономики
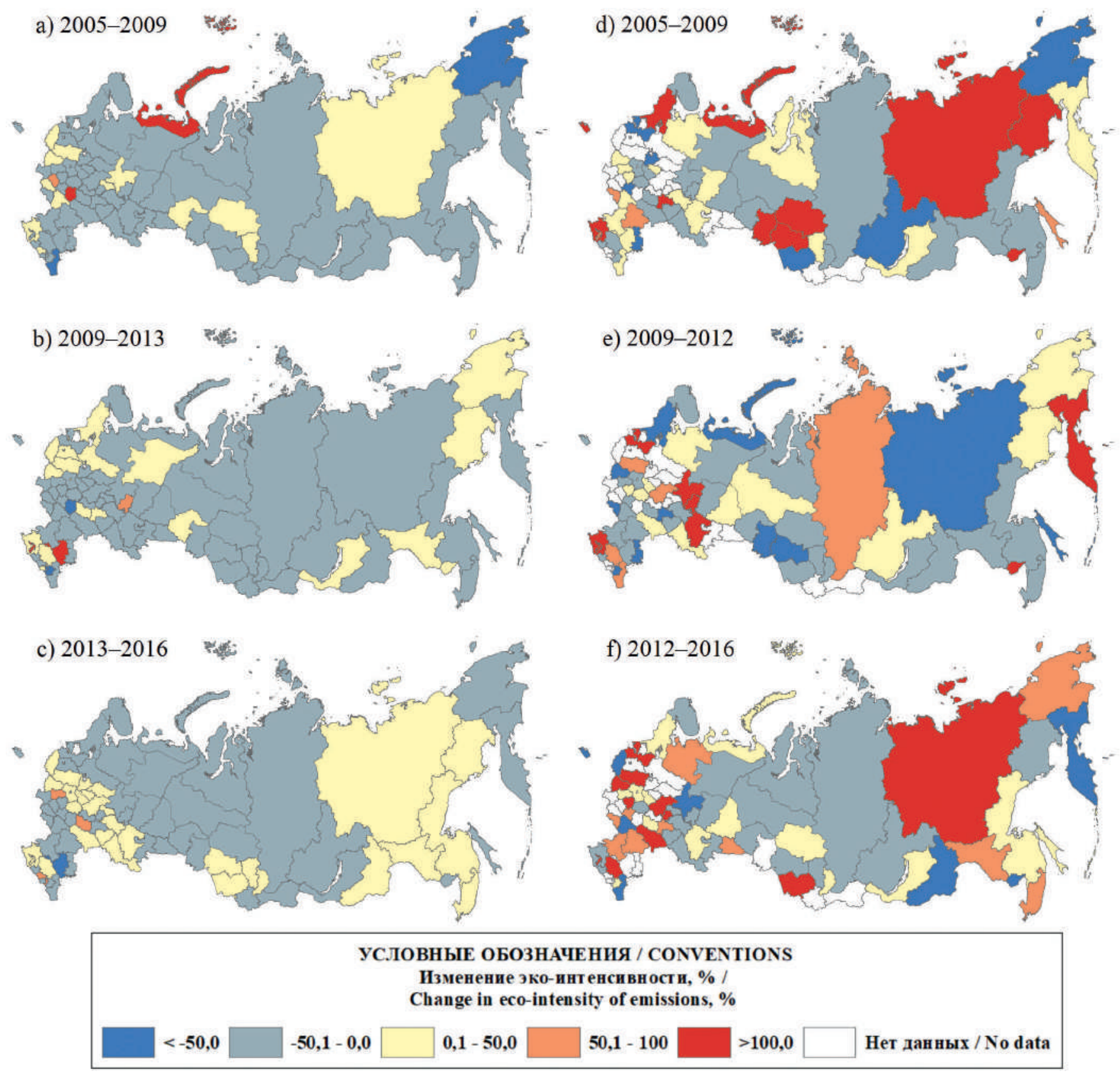

Pис. 1. Изменение эко-интенсивности выбросов загрязняющих вещуеств в атмосферу от стационарных источников 8 регионах РФ: $a-c-$ по экономике в целом; $d-f$-для ВЭД «Добыча полезных ископаемых»

Fig 1. Changes of the eco-intensity of air pollutant emissions in the Russian regions: $a-c$-for the economy as a whole; $d-f-f o r$ the mining and quarrying activities 
Таблица 3 / Table 3

Группировка регионов в зависимости от изменения эко-интенсивности выбросов наиболее распространенных загрязняющих веществ

Grouping of regions depending on changes in the eco-intensity of the most common pollutants emissions

\begin{tabular}{|c|c|c|c|}
\hline \multirow{2}{*}{$\begin{array}{c}\text { Изменение эко- } \\
\text { интенсивности } \\
\text { Change in eco- } \\
\text { intensity } \\
\end{array}$} & 2005-2009 & 2009-2013 & 2013-2016 \\
\hline & \multicolumn{3}{|c|}{ Твёрдые вещества / Solids } \\
\hline$>100 \%$ & \begin{tabular}{|c|} 
Два региона: Кабардино-Бал- \\
карская Республика, \\
Республика Адыгея \\
Two regions: Kabardino-Balkari- \\
an Republic, Republic of Adygeya
\end{tabular} & $\begin{array}{c}\text { Один регион: Республика } \\
\text { Адыгея } \\
\text { One regions: Republic of } \\
\text { Adygeya }\end{array}$ & $\begin{array}{c}\text { Один регион: РСО-Алания } \\
\text { One regions: Republic of North Ossetia - } \\
\text { Alania }\end{array}$ \\
\hline $0-100 \%$ & 13 регионов / 13 regions & 14 регионов / 14 regions & 30 регионов / 30 regions \\
\hline \multirow[t]{2}{*}{$\begin{array}{l}\text { Снижение } \\
\text { Decrease }\end{array}$} & 67 регионов / 67 regions & 67 регионов / 67 regions & 51 регион / 51 regions \\
\hline & \multicolumn{3}{|c|}{ Диоксид серы / Sulfur dioxide } \\
\hline$>100 \%$ & $\begin{array}{c}\text { Два региона: Ненецкий авто- } \\
\text { номный округ (АО), Республика } \\
\text { Татарстан } \\
\text { Two regions: Republic of Ta- } \\
\text { tarstan, Nenets Autonomous Area }\end{array}$ & $\begin{array}{l}\text { Два региона: Республика } \\
\text { Дагестан, Республика Коми } \\
\text { Two regions: Republic of } \\
\text { Daghestan, Komi Republic }\end{array}$ & $\begin{array}{c}\text { Шесть регионов: } \\
\text { Оренбургская область, Республика } \\
\text { Адыгея, Республика Мордовия, Респу- } \\
\text { блика Татарстан, Чувашская Республи- } \\
\text { ка, Ямало-Ненецкий АО } \\
\text { Six regions: Orenburg Region, Republic of } \\
\text { Adygeya, Republic of Mordovia, Republic } \\
\text { of Tatarstan, Chuvash Republic, Yamal- } \\
\text { Nenets Autonomous Area }\end{array}$ \\
\hline $0-100 \%$ & 19 регионов / 19 regions & 15 регионов / 15 regions & 24 региона / 24 regions \\
\hline \multirow[t]{2}{*}{$\begin{array}{c}\text { Снижение } \\
\text { Decrease }\end{array}$} & 62 региона / 62 regions & 63 региона / 63 regions & 50 регионов / 50 regions \\
\hline & \multicolumn{3}{|c|}{ Оксид углерода / Carbon monoxid } \\
\hline$>100 \%$ & \begin{tabular}{|c|} 
Два региона: Ненецкий АО, Ка- \\
бардино-Балкарская Республика \\
Two regions: Nenets Autono- \\
mous Area, Kabardino-Balkarian \\
Republic
\end{tabular} & $\begin{array}{c}\text { Два региона: Республика } \\
\text { Адыгея, Удмуртская Респу- } \\
\text { блика } \\
\text { Two regions: Republic } \\
\text { of Adygeya, Republic of } \\
\text { Kalmykia }\end{array}$ & $\begin{array}{l}\text { Нет регионов } \\
\text { No regions }\end{array}$ \\
\hline $0-100 \%$ & 19 регионов / 19 regions & 20 регионов / 20 regions & 30 регионов / 30 regions \\
\hline \multirow[t]{2}{*}{$\begin{array}{l}\text { Снижение } \\
\text { Decrease }\end{array}$} & 62 региона / 62 regions & 61 регион / 61 regions & 53 региона / 53 regions \\
\hline & \multicolumn{3}{|c|}{ Оксиды азота / Nitrogen oxides } \\
\hline$>100 \%$ & $\begin{array}{l}\text { Нет регионов } \\
\text { No regions }\end{array}$ & $\begin{array}{l}\text { Один регион: Республика } \\
\text { Дагестан } \\
\text { One regions: Republic } \\
\text { of Daghestan }\end{array}$ & $\begin{array}{l}\text { Нет регионов } \\
\text { No regions }\end{array}$ \\
\hline $0-100 \%$ & 27 регионов / 27 regions & 26 регионов / 26 regions & 33 региона / 33 regions \\
\hline $\begin{array}{l}\text { Снижение } \\
\text { Decrease }\end{array}$ & $\begin{array}{c}56 \text { регионов } \\
56 \text { regions }\end{array}$ & $\begin{array}{c}55 \text { регионов } \\
55 \text { regions }\end{array}$ & $\begin{array}{c}49 \text { регионов } \\
49 \text { regions }\end{array}$ \\
\hline
\end{tabular}

Примечание: Составлено авторами на основе собственных расчетов [22].

Note: Compiled by authors on the basis of their own calculations [22].

в целом. Например, в Приморском крае удельные выбросы в добывающем секторе в 4,5 раза выше, чем по экономике в целом; в Ненецком АО - в 1,3 раза (данные за 2016 г.). Таким образом, следующим этапом исследования является оценка и анализ динамики экоинтенсивности в данной отрасли.
Динамика эколого-экономического развития ВЭД «Добыча полезных ископаемых» в российских регионах неодинакова (рис. $1, d-f$ ). Заметное увеличение эко-интенсивности в период с 2005 по 2009 г. в большинстве субъектов произошло за счет существенного роста объемов эмиссий загрязняющих веществ от гор- 
нодобывающих предприятий. Так, например, в Республике Саха в 2005 г. от стационарных источников было выброшено 31,3 тыс. тонн загрязняющих веществ, а в 2009 г. уже в 2,1 раза больше - 65,9 тыс. тонн, при этом вклад в ВРП добывающей промышленности за данный временной интервал уменьшился на $28,4 \%$. Дальнейшее развитие горнодобывающей промышленности может заметно влиять на динамику изучаемых показателей, в особенности в регионах с выраженной сырьевой ориентацией хозяйственных систем.

В период 2009-2012 гг. произошло увеличение количества регионов с отрицательной динамикой эко-интенсивности - 37 регионов (против 30 в $2005-$ 2009 гг.). Мировой финансовый кризис затронул и горнодобывающую промышленность. В связи с падением промышленного производства в ряде регионов в данном секторе произошло и сокращение выбросов загрязняющих веществ в атмосферу. Уменьшение объемов эмиссий и, соответственно, показателей эко-интенсивности произошло, в том числе, за счет промышленной рецессии.

В период с 2012 по 2016 г. в некоторых западных регионах, Алтайском крае и Республике Саха отмечалось значительное увеличение эко-интенсивности, связанное с ростом эмиссии загрязняющих веществ. За этот временной интервал в тридцати шести регионах наблюдался рост исследуемого показателя. Лишь в ряде субъектов (Забайкальский край, Мурманская и Самарская области, Республика Башкортостан, Коми и Карачаево-Черкесская Республика) на протяжении всех рассматриваемых периодов было зафиксировано устойчивое снижение удельных выбросов в сфере добычи полезных ископаемых. Развитие добывающего сектора в Магаданской и Кемеровской областях характеризовалось постепенным снижением негативного воздействия в расчете на единицу результата хозяйственной деятельности, что является позитивной тенденцией в геэкологическом контексте.

Сравнительная оценка показателей эко-интенсивности выбросов наиболее распространенных загрязняющих веществ позволит выявить наиболее проблемные регионы с точки зрения экологических проблем, связанных с конкретными загрязнителями. Например, выбросы твёрдых веществ от стационарных источников оказывают значительное воздействие на здоровье людей, вызывая тяжелые заболевания дыхательных путей. В табл. 3 представлен перечень субъектов РФ с существенным увеличением эко-интенсивности выбросов наиболее распространенных загрязняющих веществ в различные периоды времени.

Выполненный анализ показал, что в период с 2013 по 2016 г. по всем видам загрязнителей произошло заметное увеличение числа регионов, характеризующихся ростом эко-интенсивности, что, по-видимому, можно считать негативной общерегиональной тенденцией. Наибольший рост удельной экологической нагрузки наблюдается в отношении выбросов оксида углерода и оксидов азота. В 2005-2009 гг. наихудшую динамику эко-интенсивности выбросов наиболее распространённых загрязняющих веществ демонстрировали Ненецкий АО, Кабардино-Балкарская Республика, Республики Татарстан и Адыгея; в 2009-2013 гг. - республики Адыгея, Дагестан, Коми и Удмуртская; 2013-2016 гг. - ряд регионов, расположенных преимущественно в европейской части России.

Исследование динамики эко-интенсивности выбросов твёрдых веществ на региональном уровне позволяет сделать вывод о заметном ухудшении ситуации в восточных регионах, в том числе и вовлеченных в трансграничное взаимодействие с КНР (Приморский край, Республика Бурятия, Забайкальский край) (рис. $2, a-c$ ). При этом стоит отметить, что фактически во всех регионах Дальневосточного и Сибирского федеральных округов эко-интенсивность выбросов твёрдых веществ в атмосферу превышает среднероссийский уровень в 2-6 раз. Основным источником эмиссий данного загрязняющего вещества на этих территориях являются тепловые электростанции, работающие преимущественно на твердом топливе.

Что касается эко-интенсивности выбросов диоксида серы, то в 2013-2016 гг. наблюдается ухудшение ситуации в восточных регионах (Чукотский АО, Республика Саха, Амурская область и Хабаровский край), в Уральском федеральном округе (за исключением Свердловской, Курганской и Челябинской областей) и в некоторых западных регионах по сравнению с предыдущими периодами (рис. $2, d-f$ ).

Перейдем к анализу распределения эко-интенсивности выбросов оксида углерода от стационарных источников (рис. 3, $a-c$ ). За период с 2005 по 2009 гг. в регионах с существенным приростом данного показателя значительно увеличилась эмиссия оксида углерода: в Кабардино-Балкарской Республике и Ненецком $\mathrm{AO}$ - втрое, в Ненецком АО - в 2,9 раза, в Воронежской области - в 2,1 раза, в Санкт-Петербурге - вдвое. В 2009-2012 гг. для нефтегазовых регионов (исключение - Ханты-Мансийский АО) характерно наибольшее снижение эко-интенсивности, которое объясняется значительным уменьшением выбросов этого вещества. Особое место занимает Ненецкий АО, в котором произошло наибольшее сокращение выбросов оксида углерода - в 3 раза, поэтому регион перешёл в наиболее благоприятную зону. Данный факт объясняется очевидными последствиями финансовоэкономического кризиса 2009 г. - цены на экспортную продукцию уменьшились, промышленное производство снизилось (рис. 4), соответственно, негативное воздействие на атмосферу $(95,5 \%$ от общего объема выбросов принадлежит ВЭД «Добыча полезных ископаемых») уменьшилось.

Природно-ресурсные регионы характеризуются крайне неустойчивым изменением эко-интенсивно- 

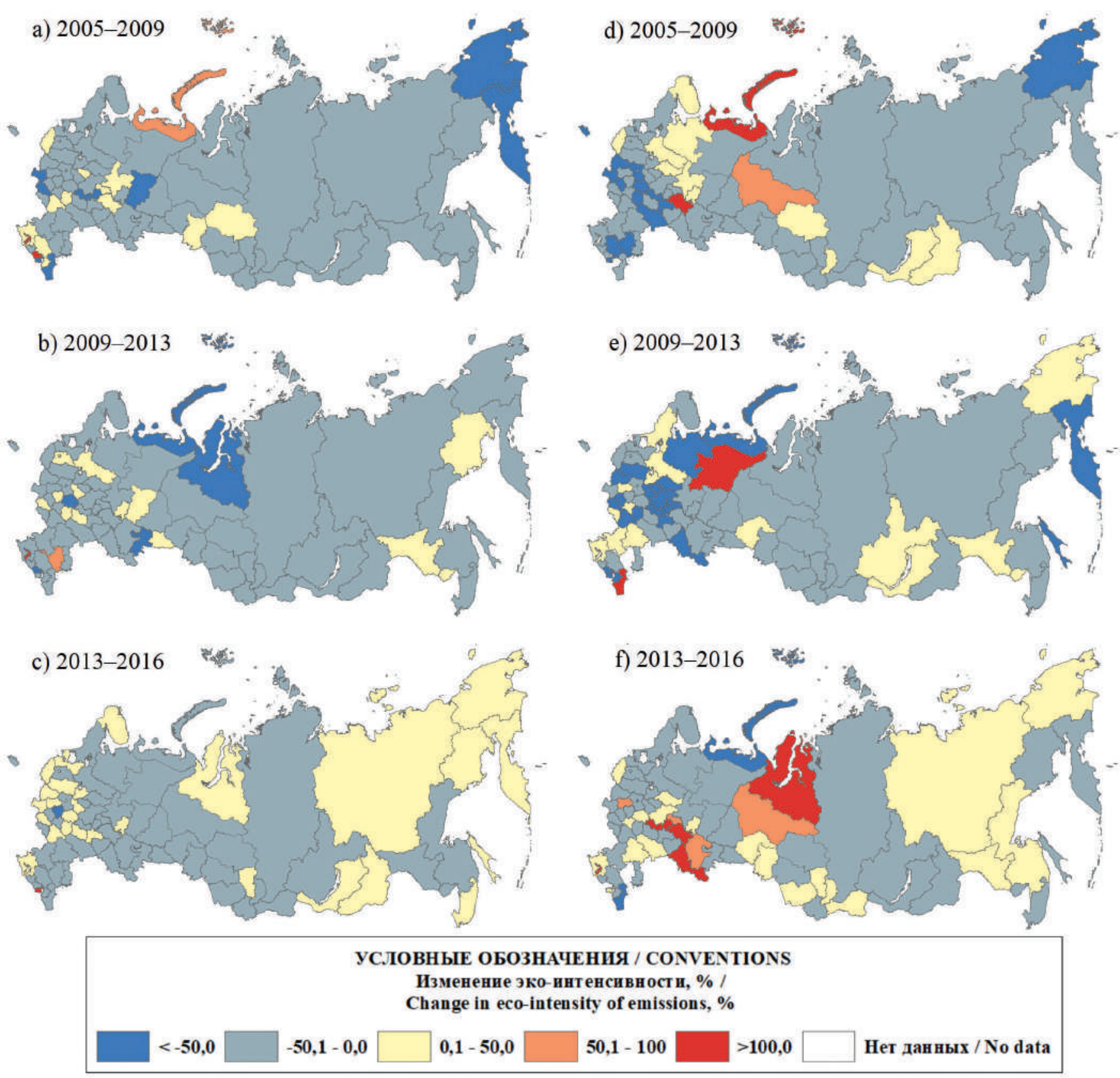

Pис. 2. Изменение эко-интенсивности выбросов загрязняющих веществ в атмосферу от стационарных источников в регионах РФ: $a-c-$ твердые вещества; $d-f$-диоксид серы

Fig 2. Changes of the eco-intensity of air pollutant emissions in the Russian regions: $a-c-s o l i d s ; d-f$-sulfur dioxide

сти выбросов оксида углерода за рассматриваемые временные интервалы. В 2013-2016 гг. в Республике Саха, в нефтегазовых (за исключением ХантыМансийского АО), приграничных (Приморский край, Амурская область, Забайкальский край, Республика Тыва, Алтайский край, Новосибирская область), некоторых западных регионах отмечается ухудшение ситуации, в данных регионах экологические показатели в расчете на единицу экономических благ в виде добавленной стоимости существенно превосходят общероссийский уровень.

В отношении выбросов оксидов азота в большинстве регионов отмечалось снижение эко-интенсивности выбросов за все рассматриваемые периоды (рис. 3, $d-f)$. Из представленных на рис. $3, d$ данных видно, что заметный рост показателя наблюдался только в одном регионе - Рязанской области, он составил $62,7 \%$, в то время как на национальном уровне удельные выбросы снизились на 9,4 \%. Небольшой прирост эко-интенсивности характерен для сырьевых регионов Сибири и Дальнего Востока (Республика Саха, Амурская, Иркутская и Сахалинская области), ряда территорий Урала (Ханты-Мансийский АО, Курганская, Свердловская, Тюменская области), а также для некоторых регионов в западной части России. В 2009-2013 гг. отмечена позитивная тенденция снижения эко-интенсивности в сырьевых регионах. В этот же период в Республике Дагестан произошел значительный рост эко-интенсивности - $117,3 \%$, связанный с ростом эмиссии оксида азота (в 2,7 раза). Анализируя рис. $3, f$, 

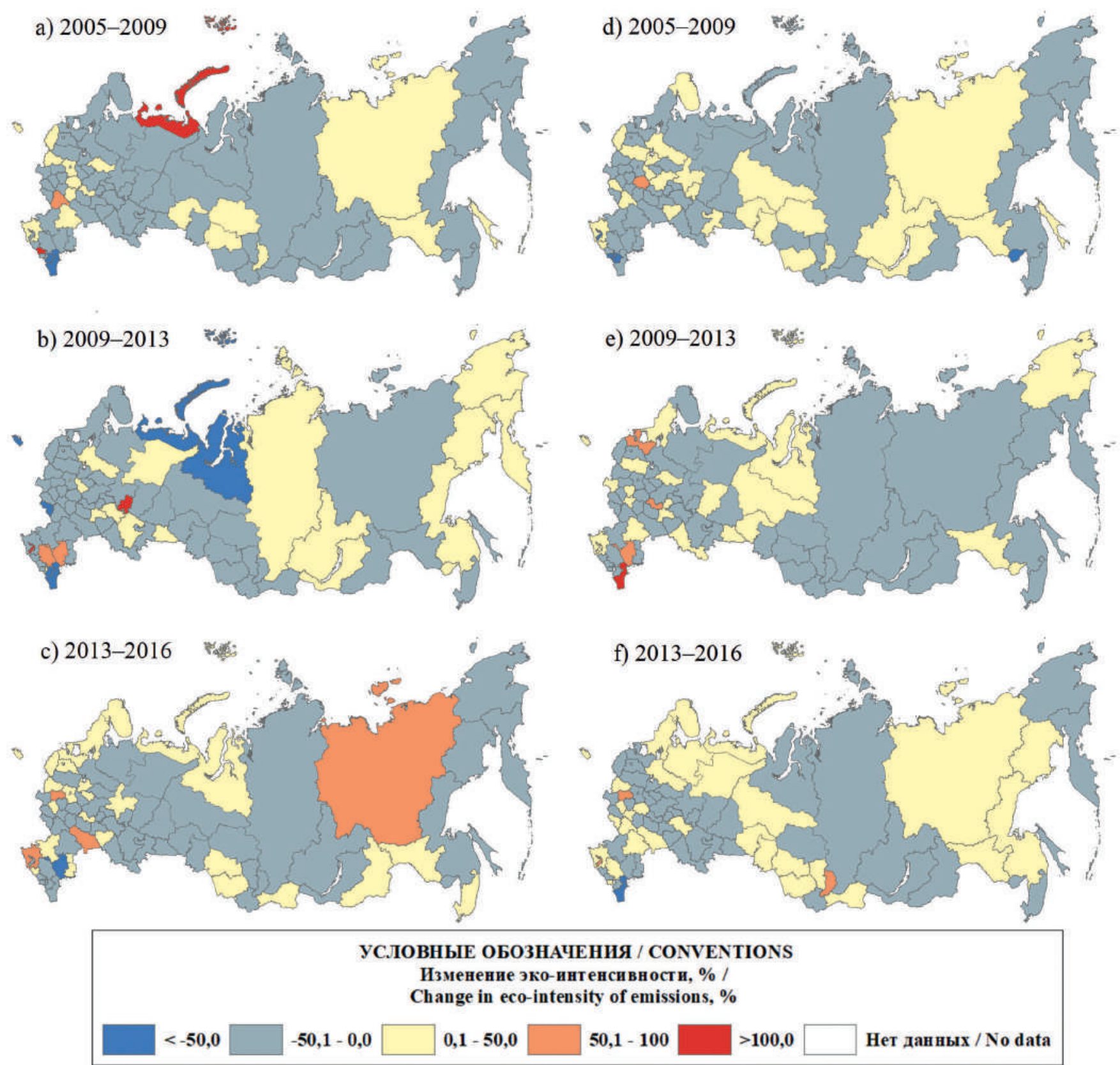

Puc. 3. Изменение эко-интенсивности выбросов загрязняющих веществ в атмосферу от стационарньх источников 6

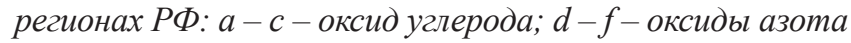

Fig 3. Changes of the eco-intensity of air pollutant emissions in the Russian regions: $a-c$-carbon monoxide; $d-f$-nitrogen oxides

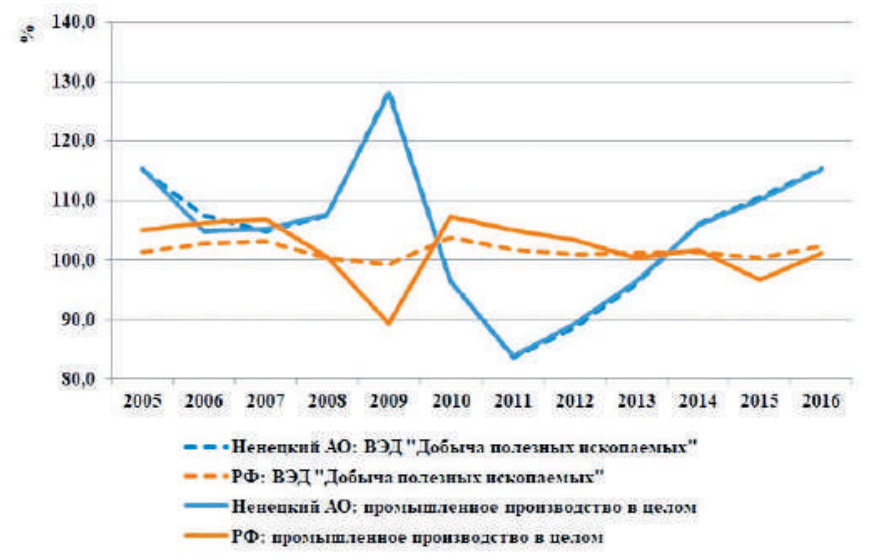

Pис. 4. Индексы промышиенного производства, 2005-2016 г2., \%

Fig. 4. Industrial production indexes, 2005-2016, \% можно заключить, что Республика Саха, Магаданская, Сахалинская и Амурская области за период с 2013 по 2016 г. характеризовались ростом изучаемого показателя. В этом же временном интервале прослеживается ухудшение ситуации на уральских территориях и в северо-западных регионах. В Ханты-Мансийском АО, Тюменской, Амурской областях и в Краснодарском крае выявлено устойчивое повышение эко-интенсивности на протяжении всех рассматриваемых в исследовании периодов.

\section{Заключение}

Выполненный сравнительный анализ динамики эко-интенсивности выбросов загрязняющих веществ показал, что в последние годы наблюдается негатив- 
ная тенденция увеличения числа регионов, характеризующихся ростом удельного негативного воздействия на атмосферу. Рассмотрение ситуации в разрезе наиболее распространенных загрязняющих веществ позволило выявить высокую степень пространственной неоднородности регионов по динамике геоэкологических показателей качества экономического роста. В 2013-2016 гг. наихудшая динамика эко-интенсивности по всем видам загрязнителей присуща некоторым природно-ресурсным регионам Сибири и Дальнего Востока (в том числе и приграничным), а также отдельным регионам, расположенным на Урале и в европейской части РФ.

В процессе исследования эколого-экономических аспектов развития горнодобывающей промышленности было выявлено, что эко-интенсивность выбросов от добычи полезных ископаемых в некоторых регионах заметно выше, чем в целом по экономике. Например, в одном из приграничных регионов - Приморском крае - количество выбросов в атмосферу в расчете на единицу экономического результата в добывающем секторе оказалось в 4,5 раза выше, чем в целом по экономике (по данным за 2016 г.). Кроме того, развитие ВЭД «Добыча полезных ископаемых» характеризовалось ростом эко-интенсивности, который в некоторых регионах оказался весьма ощутимым.

Таким образом, мы не можем говорить о том, что экологическая модернизация в горнодобывающей отрасли большинства регионов успешно состоялась, скорее, наоборот. В работе [24] подчеркивается необходимость осуществления в природно-ресурсных регионах не только технологической, но и экологической модернизации, для стимулирования которой необходим комплекс мер на всех уровнях управления.

Показатели эко-интенсивности в динамике характеризуют также тенденции развития хозяйственных систем в контексте экологической безопасности. Полученные результаты позволяют сделать вывод, что существующие государственные институты далеко не в полной мере выполняют свою задачу регулирования с целью стимулирования экологической модернизации и обеспечения устойчивого развития регионов.

Работа выполнена по проекту Программы фундаментальных исследований СО РАН (XI.174.1).

The work was performed under the project of the Program of fundamental research of Siberian Branch of Russian Academy of Sciences (XI.174.1).

\section{КОНФЛИКТ ИНТЕРЕСОВ / Conflict of interest:}

Авторы заявляют об отсутствии конфликта интересов / The authors declare no conflict of interest.

\section{$\overline{\text { ЛИТЕРАТУРА: }}$}

1. Шкиперова Г.Т. Анализ и моделирование взаимосвязи между экономическим ростом и качеством окружающей среды (на примере Республики Карелия) // Экономический анализ: теория и практика. 2014. N43 (394). С. 41-49.

2. Стратегия социально-экономического развития Дальнего Востока и Байкальского региона на период до 2025 года [Электронный ресурс]. Режим доступа: http://docs.cntd.ru/document/902195483 (дата обращения: 20.08.2018).

3. Антонова Н.Е., Ломакина Н.В. Природно-ресурсные отрасли Дальнего Востока: новые факторы развития // Экономические и социальные перемены: факты, тенденции, прогноз. 2018. T. 11. N1. C. 43-56. DOI: 10.15838/ esc/2018.1.55.3

4. Забелина И.А., Клевакина Е.А. Приграничное сотрудничество и его влияние на качество экономического роста (на примере Забайкальского края) // ЭКО. 2013. N5 (467). С. 108-123.

5. Стратегия экологической безопасности Российской Федерации на период до 2025 года [Электронный ресурс]. Режим доступа: http://docs.cntd.ru/document/420396664 (дата обращения: 20.08.2018).

6. Кулясов И.П. Экологическая модернизация: теоретические аспекты // Журнал социологии и социальной антропологии. 2005. T. VIII. N3. C. 100-113.

7. De Haan M. Accounting for goods and bads. Voorburg: Statistics Netherlands. 2004. 216 p.
8. Экологические индикаторы качества роста региональной экономики / Под ред. И.П. Глазыриной, И.М. Потравного. М.: НИА-Природа, 2005. 306 с.

9. Fan Y., Liu L.-C., Wu G., Tsai H.-T. Wei Y.-M. Changes in carbon intensity in China: Empirical findings from 1980-2003 // Ecological Economics. Vol. 62. Issues 3-4. May 2007. Pp. 683-691. URL: https://doi.org/10.1016/j. ecolecon.2006.08.016

10. Wang H., Ang B.W., Su B. A Multi-region Structural Decomposition Analysis of Global CO2 Emission Intensity // Ecological Economics. Vol. 142. December 2017. Pp. 163176. URL: https://doi.org/10.1016/j.ecolecon.2017.06.023

11. Castaneda B. An index of sustainable economic welfare (ISEW) for Chile // Ecological Economics. 1999. N28. Pp. 231-244.

12. Clarke M., Islam S. Diminishing and negative welfare returns of economic growth: an index of sustainable economic welfare (ISEW) for Thailand // Ecological Economics. 2005. N54. Pp. 81-93.

13. Галачиева С.В., Махошева С.А., Эркенова Л.З. Система показателей оценки устойчивого регионального развития // Устойчивое развитие горных территорий. 2015. N2. C. 53-60.

14. Сырцова Е.А., Пыжев А.И., Зандер Е.В. Истинные сбережения регионов Сибири: новые оценки, старые проблемы // ЭКО. 2016. N6 (504). С. 109-129.

15. Бобылев С.Н., Соловьева С.В., Ситкина К.С. Инди- 
каторы устойчивого развития Уральского региона // Экономика региона. 2013. N2. C. 10-17.

16. Wursthorn S., Poganietz W.-R., Schebek L. Economicenvironmental monitoring indicators for European countries: A disaggregated sector-based approach for monitoring ecoefficiency // Ecological Economics. Vol. 70. Issue 3. 15 January 2011. Pp. 487-496. URL: https://doi.org/10.1016/j. ecolecon.2010.09.033

17. Индикаторы устойчивого развития России (эколого-экономические аспекты). / Под ред. С.Н. Бобылева, П.А. Макеенко. М.: ЦПРП. 2001. 220 с.

18. Бобылев С.Н., Захаров В.М. Кризис: экономика и экология. М.: ООО «Типография ЛЕВКО», 2009. С. 17-18.

19. 2014-2015 годы: экономический кризис - социальное измерение / Под ред. Т.М. Малевой. М.: Издательский дом «Дело» РАНХиГС, 2016. 112 с. (Научные доклады: социальная политика).
20. Мкртчян Г.М., Тагаева Т.О., Цвелодуб Ю.О. Анализ и прогноз экологической нагрузки в России // Мир экономики и управления. 2017. T. 17. N1. С. 57-69.

21. Glazyrina I, Glazyrin V., Vinnichenko S. The polluter pays principle and potential conflicts in society // Ecological Economics. 2006. Vol. 59. Pp. 324-330. doi.org/10.1016/j. ecolecon.2005.10.020

22. Федеральная служба государственной статистики [Электронный ресурс]. Режим доступа: http://www.gks.ru/ (дата обращения: 20.08.2018).

23. Глазырина И.П., Забелина И.А., Клевакина Е.А. Уровень экономического развития и распределение экологической нагрузки между регионами РФ // Журнал новой экономической ассоциации. 2010. N7. C. 70-88.

24. Природный капитал региона и российско-китайские трансграничные отношения: перспективы и риски / Под ред. И.П. Глазыриной, Л.М. Фалейчик. Чита: ЗабГУ. 2014. 527 с.

\title{
СВЕДЕНИЯ ОБ АВТОРАХ / Information about authors:
}

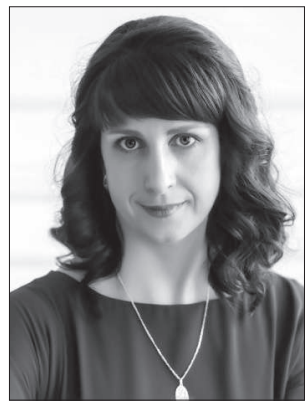

ЗАБЕЛИНА Ирина Александровна* - научный сотрудник Лаборатории эколого-экономических исследований, кандидат экономических наук.

Круг научных интересов: экономика природопользования, региональная экономика, экологическая экономика, межрегиональное неравенство, экологическая нагрузка.

Институт природных ресурсов, экологии и криологии CO РАН, 672002, г. Чита, Россия

Тел.: +7 (914) 462-37-58

E-mail: i_zabelina@mail.ru

Irina Al. ZABELINA - researcher of the Laboratory of Ecological and Economic Studies, Candidate of Economic Sciences.

Sphere of scientific interests: environmental economics, regional economics, ecological economics, interregional inequality, environmental pressure.

Institute of Natural Resources, Ecology and Cryology SB RAS, 672002, Chita, Russia

Ph.: +7 (914) 462-37-58

E-mail: i_zabelina@mail.ru

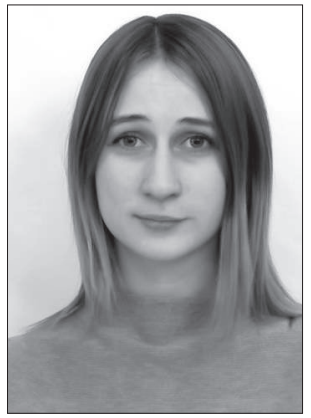

ДЕЛЮГА Анастасия Васильевна - инженер Лаборатории эколого-экономических исследований.

Круг научных интересов: региональная экономика, экологическая экономика, информационные системы.

Институт природных ресурсов, экологии и криологии СО РАН, 672002, г. Чита, Россия

Тел.: +7 (924) 271-03-44

E-mail: n.delyuga@gmail.com

Anastasiya V. DELYUGA - engineer of the Laboratory of Ecological and Economic Studies.

Sphere of scientific interests: regional economics, ecological economics, information systems.

Institute of Natural Resources, Ecology And Cryology SB RAS, 672002, Chita, Russia

Ph.: +7 (924) 271-03-44

E-mail:n.delyuga@gmail.com

\section{GEOECOLOGICAL INDICATORS OF SUSTAINABLE DEVELOPMENT: SPATIAL ANALYSIS}

\author{
${ }^{1}$ I. A. Zabelina, * \\ ${ }^{1}$ A. V. Deluga \\ ${ }^{1}$ Institute of Natural Resources, Ecology and Cryology, Russian Academy of Sciences, Siberian Branch, 672002, Chita, Russia, \\ i_zabelina@mail.ru
}

\section{DOI: $10.21177 / 1998-4502-2019-11-1-15-25$}

Ecological processes of modernization of regional economic systems by means of dynamics of indicators of impact on the environment in Russian regions are investigated. To receive quantitative features, we used one of geoecological indicators of quality of the environment of economic growth - "eco-intensity". It characterizes the level of negative impact on environment per unit of the result of economic activity. An indicator of the environmental load is the volume of air pollutant emissions from stationary sources (including the most common pollutants: solids, sulfur dioxide, carbon monoxide, nitrogen oxides). The gross regional domestic product (converted into 2005 constant prices in conjunction with official GRDP growth rates) is used as a characteristic of the result of economic activity 
in the regions. The study of the dynamics of eco-intensity of air pollutant emissions was carried out in different time intervals: 2005-2009, 2009-2013 and 2013-2016. Special attention is paid to the study of environmental aspects of the development of the mining industry, which is the basis of economic activity of many resource-extracting regions of the Russian Federation. For the spatial analysis of the dynamics of the studied geo-ecological indicators the tools of GIS-technologies were used. Assessment of the dynamics of eco-intensity of air pollutant emissions from stationary sources showed that in recent years there has been a marked increase in the number of regions characterized by an increase in the specific environmental load. The worst dynamics of eco-intensity of emissions of the most common pollutants was observed in the regions of Siberia, the Far East and the Urals, as well as in few regions of the European part of the Russian Federation. Natural resource extraction and processing activities have a significant negative impact on the natural environment. In some resource-extracting regions, the eco-intensity of emissions in the mining industry was significantly higher than for the economy as a whole. The results of a comparative analysis of the environmental and economic development of the mining industry showed that in some regions there was an increase in eco-intensity (in some it was very noticeable). The results allow us to conclude that the existing state institutions do not fully fulfill their task of regulation in order to stimulate environmental modernization and sustainable development of the regions.

Keywords: eco-intensity, mining and quarrying activities, environmental modernization, negative impact on the environment, regions of Russia.

\section{References:}

1. Shkiperova G.T. Analysis and modeling of relationship between economic growth and environmental quality (the case of the Republic of Karelia). Economic Analysis: Theory and Practice, 2014, no. 43 (394), pp. 41-49. (In Russian)

2. Strategy of socio-economic development of the Far East and the Baikal Region up to 2025 [Electronic resource]. Access mode: http://docs.cntd.ru/document/902195483 (accessed 20.08.2018)

3. Antonova N.E., Lomakina N.V. Natural Resource-Based Industries of the Far East: New Drivers of Development. Economic and Social Changes: Facts, Trends, Forecast. 2018, v. 11, no. 1, pp. 43-56. DOI: 10.15838/esc/2018.1.55.3 (in Russian)

4. Zabelina I.A., Klevakina E.A. The International Economic co-operation and its Influence on Quality of Economic Growth: a Case Study of Zabaikalsky Krai. ECO, 2013, no. 5 (467), pp. 108-123. (In Russian)

5. Strategy of environmental safety of Russian Federation up to 2025 [Electronic resource]. Access mode: http://docs.cntd. $\mathrm{ru} /$ document/420396664 (accessed 20.08.2018)

6. Kulyasov I. Ecological Modernization Theory. The Journal of Sociology and Social Anthropology, 2005, v. VIII, no. 3, pp. 100-113. (In Russian)

7. De Haan M. Accounting for goods and bads. Voorburg, Statistics Netherlands, 2004, 216 p.
8. Quality of growth indicators for regional economies. I.P. Glazyrina, I.M. Potravny ed. Moscow, NIA-Priroda, 2005, 306 p.

9. Fan Y., Liu L.-C., Wu G., Tsai H.-T. Wei Y.-M. Changes in carbon intensity in China: Empirical findings from 1980 2003. Ecological Economics, vol. 62, issues 3-4, May 2007, pp. 683-691. URL: https://doi.org/10.1016/j.ecolecon.2006.08.016

10. Wang H., Ang B.W., Su B. A Multi-region Structural Decomposition Analysis of Global CO2 Emission Intensity. Ecological Economics, vol. 142, December 2017, pp. 163-176. URL: https://doi.org/10.1016/j.ecolecon.2017.06.023

11. Castaneda B. An index of sustainable economic welfare (ISEW) for Chile. Ecological Economics, 1999, no. 28, pp. 231244.

12. Clarke M., Islam S. Diminishing and negative welfare returns of economic growth: an index of sustainable economic welfare (ISEW) for Thailand. Ecological Economics, 2005, no. 54, pp. 81-93.

13. Galachieva S.V., Mahacheva S.A., Arkanova L.Z. System of indicators to measure sustainable regional development. Sustainable Development of Mountain Territories, 2015, no. 2, pp. 53-60. (In Russian)

14. Syrtsova E.A., Pyzhev A.I., Zander E.V. Genuine Savings for Siberian Regions: new Estimates, Old Problems. ECO, 2016, no. 6 (504), pp. 109-129. (In Russian)

15. Bobylev S.N., Solovyova S.V., Sitkina K.S. Sustainable development indicators of the Ural region. Economy of Region, 2013, no. 2, pp. 10-17. (In Russian)

16. Wursthorn S., Poganietz W.-R., Schebek L. Economicenvironmental monitoring indicators for European countries: A disaggregated sector-based approach for monitoring ecoefficiency. Ecological Economics, vol. 70, issue 3, 15 January 2011, pp. 487-496. URL: https://doi.org/10.1016/j.ecolecon.2010.09.033

17. Indicators of sustainable development of Russia (ekologo-economic aspects). Editors: S.N. Bobyleva, P. A. Makeyenko. Moscow, CPRP, 2001, 220 p.

18. Bobylev S. N., Zakharov V. M. Crisis: the economy and the environment. Moscow, Printing LEVKO, 2009, 84 p.

19. 2014-2015: Economic Crisis - Social Dimension. T. M. Maleva ed. Moscow, Publishing House "Delo" RANEPA, 2016, 112 p. (Scientific reports: social policy).

20. Mkrtchyan G.M., Tagaeva T.O., Tsvelodub Yu.O. Analysis and forecast of ecological load in Russia. World of Economics and Management, 2017, v. 17, no. 1, pp. 57-69. (In Russian)

21. Glazyrina I, Glazyrin V., Vinnichenko S. The polluter pays principle and potential conflicts in society. Ecological Economics, 2006, vol. 59, pp. 324-330. URL: doi.org/10.1016/j. ecolecon.2005.10.020

22. Federal State Statistics Service [Electronic resource]. Access mode: http://www.gks.ru/ (accessed 20.08.2018)

23. Glazyrina I., Zabelina I., Klevakina E. Economic Development and Environmental Impact Disparities among Russia's Regions. Journal of the New Economic Association, 2010, no. 7, pp. 70-88. (In Russian)

24. The natural capital of the region and russian-chinese cross-border relations: perspectives and risks. Editors: I. P. Glazyrina, L. M. Faleychik. Chita, Transbaikal State University, 2014, 527 p.

Article received 30.08.2018. 
${ }^{1}$ Mehrabi A.,

${ }^{1}$ Khabazi M.,

${ }^{2}$ Almodaresi S. A. ,

${ }^{3}$ Nohesara M. ,

4,5 Derakhshani R.*

\section{LAND USE CHANGES MONITORING OVER 30 YEARS AND PREDICTION OF FUTURE CHANGES USING MULTI-TEMPORAL LANDSAT IMAGERY AND THE LAND CHANGE MODELER TOOLS IN RAFSANJAN CITY (IRAN)}

\section{Introduction}

УДК: 636.085.7:036.94

DOI: 10.21177/1998-4502-201911-1-26-35

The purpose of this study is predicting and modeling of future changes in the Rafsanjan area, using remote sensing and GIS. The multispectral satellite data obtained from Landsat 5 (TM), 7 $(E T M+)$ and 8 (OLI) for the years 1986, 1992, 1998, 2004, 2010 and 2016, were used respectively. The supervised classification technique was applied to multitemporal Landsat images. Rafsanjan city was classified into four major LU classes including urban areas, pistachio gardens, bare-land, and salt. Change detection analysis was performed to compare the quantities of land use class variation between time intervals. The results revealed both increase and decrease of the different LU classes from 1986 to 2016. Generally, the conclusions indicate that during the study period, Urban areas and pistachio gardens have increased by $6.89 \%$ (18.47 $\mathrm{km} 2)$ and $12.76 \%$ (34.18 km2) while bare-land and salt have decreased by $13.43 \%$ (35.97 km2) and 9.96\% (26.68 km2), respectively. In order to predict the future land use changes map, we used the Land change modeler tools of IDRISI software. Consequently, the predicted land use map of 2022 was prepared based on the trend of 30 years of land use changes and effective variables.

\section{KEYWORDS:}

Urban expansion, Change detection, Remote sensing, Geosciences, Kerman.
Change detection is the process of identifying differences in the condition of an object or phenomenon through observation at different times [1]. The ability to understand and anticipate land use patterns changes is imperative for decision-makers and policymakers who are concerned about public resources [2]. Urbanization is an unavoidable process due to economic evolution and fast population growth. The unsustainable use of agricultural lands near urban settlements may include serious consequences such as land depreciation and desertification [3]. So far, many studies have been done on this subject such as urban expansion [4-6], flooding and drought [7-9]. But fewer studies have been conducted in relation to future changes prediction. In this study we decided to predict and model of future changes using trends of past changes. For this purpose we first used the satellite imagery techniques [10-12] to prepare land use map over 30 years in Rafsanjan city, Iran and then, based on the last 30 years land use changes and some effective variables on land use changes, we tried to predict the future changes using the Land change modeler tools of IDRISI software. The land change modeler works on the basis of the artificial neural networks that have become a popular tool in the analysis of remotely sensed data [13].

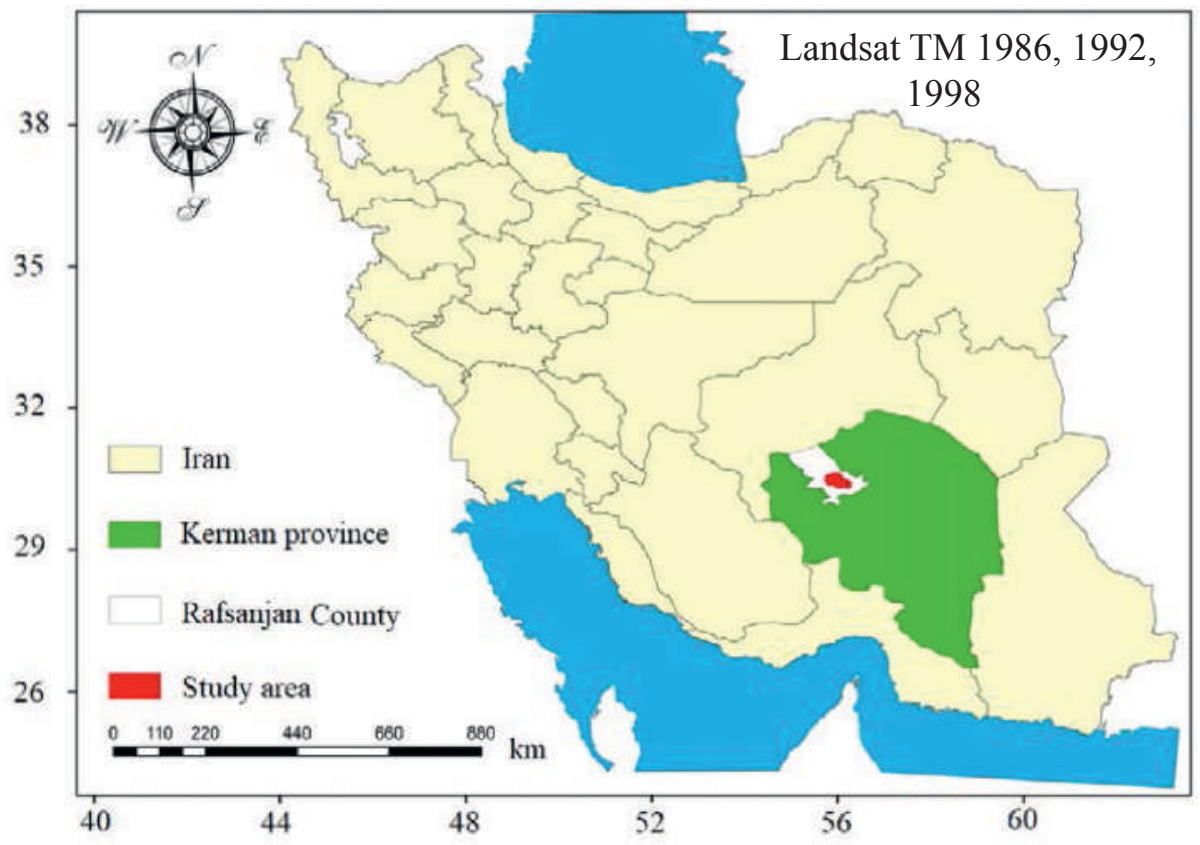

Fig. 1. Situation of Rafsanjan in Kerman province of Iran

Рис. 1. Положение Рафсанджана в иранской провинции Керман

${ }^{1}$ Department of Geography and Urban Planning, Shahid Bahonar University of Kerman, Kerman, Iran. ${ }^{2}$ Department of GIS \& RS, Yazd Branch, Islamic Azad University. Yazd, Iran.

${ }^{3}$ Department of Geography and Urban planning, Yazd Branch, Islamic Azad University, Yazd, Iran.

${ }^{4}$ Department of Geology, Shahid Bahonar University of Kerman, Kerman, Iran.

${ }^{5}$ Department of Earth Science, Utrecht University, Utrecht, The Netherlands.

*Corresponding author, e-mail: r.derakhshani@uu.nl 


\section{Materials and methods}

\section{Study area}

Rafsanjan is situated in the north of Kerman province, Iran. (Fig. 1). The area under research is approximately $270 \mathrm{~km}^{2}$. Its coordinates are $30^{\circ} 32^{\prime}$ to $30^{\circ} 45^{\prime}$ north and $56^{\circ} 10^{\prime}$ to $54^{\circ} 17^{\prime}$ east. The area has an annual rainfall of less than $100 \mathrm{~mm}$, and the climate of the area is hot and arid. Sarcheshmeh Copper mine, that is considered as the second largest copper deposit worldwide is located $50 \mathrm{~km}$ south of Rafsanjan and some people in Rafsanjan are working on this copper mine [14-17]. Pistachio is the main product of Rafsanjan and it has been known as Iran's center of pistachio cultivation and one of the most important areas for pistachio agriculture in the world. The annual production of pistachio in Iran is about 200 thousand tons, while $60 \%$ of it comes from Rafsanjan. Irrigation of pistachio gardens has been carried out through the qanats in the past, but nowadays, due to the drying of the qanats, it is done through deep wells [18]. The expansion of this city mainly depends on the regions cultivation. Observation has shown that substantial changes have taken place in this area.

\section{Image preprocessing}

Two main sets of data that were used in this study are: Satellite data and digital topographic maps. Enhanced Thematic Mapper (ETM+), Landsat Thematic Mapper (TM), and Operational Land Imager (OLI) images (with path/row 160/39) acquired in 1986, 1992, 1998, 2004, 2010 and 2016, respectively, to be anlyzed beside the digital topographic maps digitized from hardcopy topographic maps with a scale of 1:50,000 that were useful for geometric correction of the satellite images and for some ground truth information. Then, ground information was collected between 1992 to 2016 for the purpose of supervised classification and classification accuracy assessment. Performance of the study was carried out in four steps (Fig. 2):

1. Providing and performing some corrections on satellite data from six different time periods.

2. Preparing of Rafsanjan land use map.

3. Selecting effective variables to land use changes prediction.

4. Prediction of future land use changes through the integration of the effective variable maps and land use map

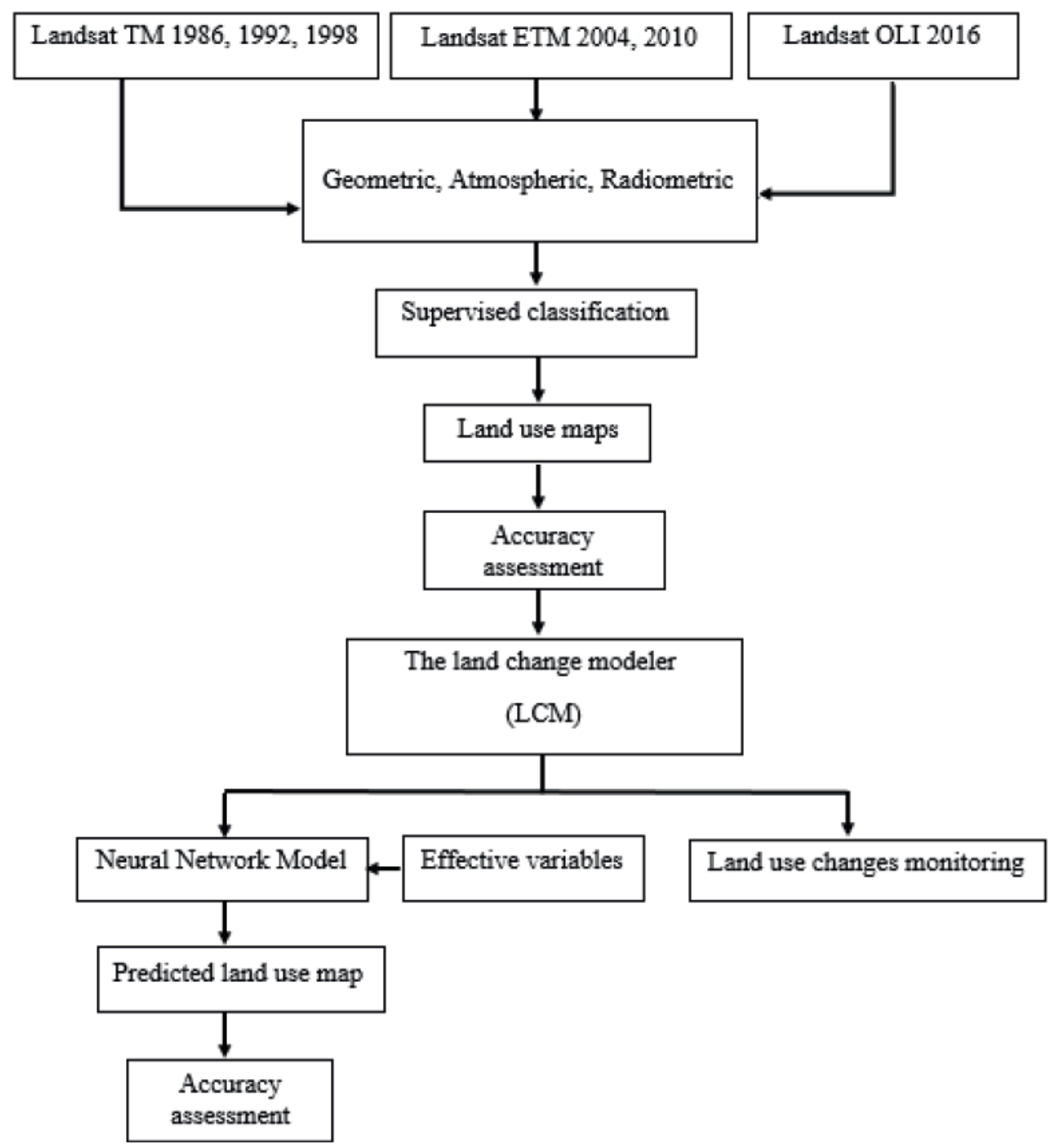

Fig. 2. General flowchart of theprocessfor the study

Pис. 2. Обшая схема исследования 
of different time periods by using the land change modeler tools in IDRISI software [19].

The aim of image preprocessing is to modify the visual interpretability of an image by increasing the certain difference between the features. Contrast stretching was applied to the all images and these images were prepared to the classification process. By implementing the supervised classification, the false color composites were created and interpreted visually using on-screen digitizing to ascertain land use classes that could be interpreted easily like garden and Salt. Visual interpretation was applied to distinct some classes that were spectrally could not be separated by supervised classification.

\section{Image classification}

By using digital topographic maps andground checkpoints,supervised classification was done inRafsanjan area to be classified into Urban areas, pistachio gardens, bare-land, and salt. 250 points in the area are used for accuracy assessment, 200 points of field data and 50 points of theland use map dated 2004 and topographic maps dated 1998. Random classified method is used for choosing the location of thses points. Also, using GIS advantages, some auxiliary data and visual interpretation was integrated to improve the accuracy of the classified image.

\section{The land change modeler}

The Land Change Modeler (LCM) for Ecological Sustainability is a software solution designed to address the prompt problem of accelerated land conversion and the very specific analytical needs of biodiversity conservation. The foundation for the LCM model is based on the artificial neural network (ANN) analysis, An ANN is a system that models the way in which the brain performs a special task. ANNs have many advantages over traditional computational methods, that's made up of nonlinear elements [13]. Inputs required by this model include 1) prior land use changes maps belong to previous years. 2) Affective variables on land use changes. The LCM model integrated mentioned layer to prepared future change detection map.

The LCM has made it possible for the user to obtain a quick estimate of the ability and the role of each variable in predicting possible land use change. In fact, the model provides a degree of correlation between variables and land uses at the end of the period by calculating the Cramer's coefficient (v) and in the range $0-1$. This correlation is presented in two ways: 1 . for each variable and land use 2 . For each variable and all land uses. Of course, it's should be noted that the rate of this coefficient in each land use is also very important in order to predict land use, since it is possible that the overall Cramer's coefficient rate for a variable to be low, but that variable should be more depended on a number of lands uses. It should be noted that the high value of the Cramer's coefficient shows the good ability of the variable but does not necessarily guarantee the excellent performance of the model since other factors also interfere in the modeling calculations and the com- plex relationships between the variables. However, when its amount is very low, it is a good indication to exclude an input variable in the prediction process. In general, values close to 0.4 and above of it are considered as the appropriate value for a variable and values less than 0.15 are considered its weak ability to predict for a variable [20].

\section{Results and discussion}

\section{Land use maps}

The output images of land use and analysis was presented in this section. The results of the visual interpretation of satellite images related to 1986, 1992, 1998, 2004, 2010, and 2016 have been shown in Fig. 3. The images used in this research were classified as the maximum likelihood classification method, and the regions of interest were prepared manually for classifying. Therefore, the images were categorized into four classes of urban areas, pistachio gardens, bare-land and salt (Fig. 3).

In order to calculate accuracy of classification, earth data should be compared to classified images in an error matrix. There are different methods to investigate accuracy of classification such as general accuracy, user accuracy, Kappa coefficient, etc. among which Kappa coefficient is more appropriate because of considering classified incorrect pixels. in this regards, educational samples from urban areas classes, pistachio gardens, bare-land and salty lands were prepared for each year and then compared with land use maps of the same year and for comparison of accuracy, the error matrix was first created and then Kappa accuracy and overall accuracy for each year have been presented in Table 1. Only Kappa accuracy numbers and overall accuracy have been given. According to Table 1 , the obtained results have fairly good accuracy, with a mean Kappa accuracy of 0.83 for all land use maps and a mean overall accuracy of $89 \%$.

Table 1 / Таблииа 1 Accuracy assessment of land use maps

Оченка точности карт землепользования

\begin{tabular}{ccc}
\hline $\begin{array}{c}\text { User's accuracy } \\
\text { (\%) }\end{array}$ & $\begin{array}{c}\text { Kappa statistic } \\
\text { Каппа землеполь- } \\
\text { зования }\end{array}$ & $\begin{array}{c}\text { Land use } \\
\text { Статистика }\end{array}$ \\
\hline бителя (\%) & 0.85 & 1986 \\
89 & 0.82 & 1992 \\
90 & 0.87 & 1998 \\
92 & 0.76 & 2004 \\
82 & 0.88 & 2010 \\
93 & 0.81 & 2016 \\
88 & 0.83 & Mean \\
89 & & \\
\hline
\end{tabular}

The total area of the studied region is 26784.28 hectares. Regarding the changes in the level of each existing uses during the 1986 to 2016 period, it has been tried to describe the situation of the area of each use in different years in Table 2. The trend and magnitude of land use change were analyzed for a period of 30 years from the benchmark year, 1986. The three decadal trend of land use change revealed that there 

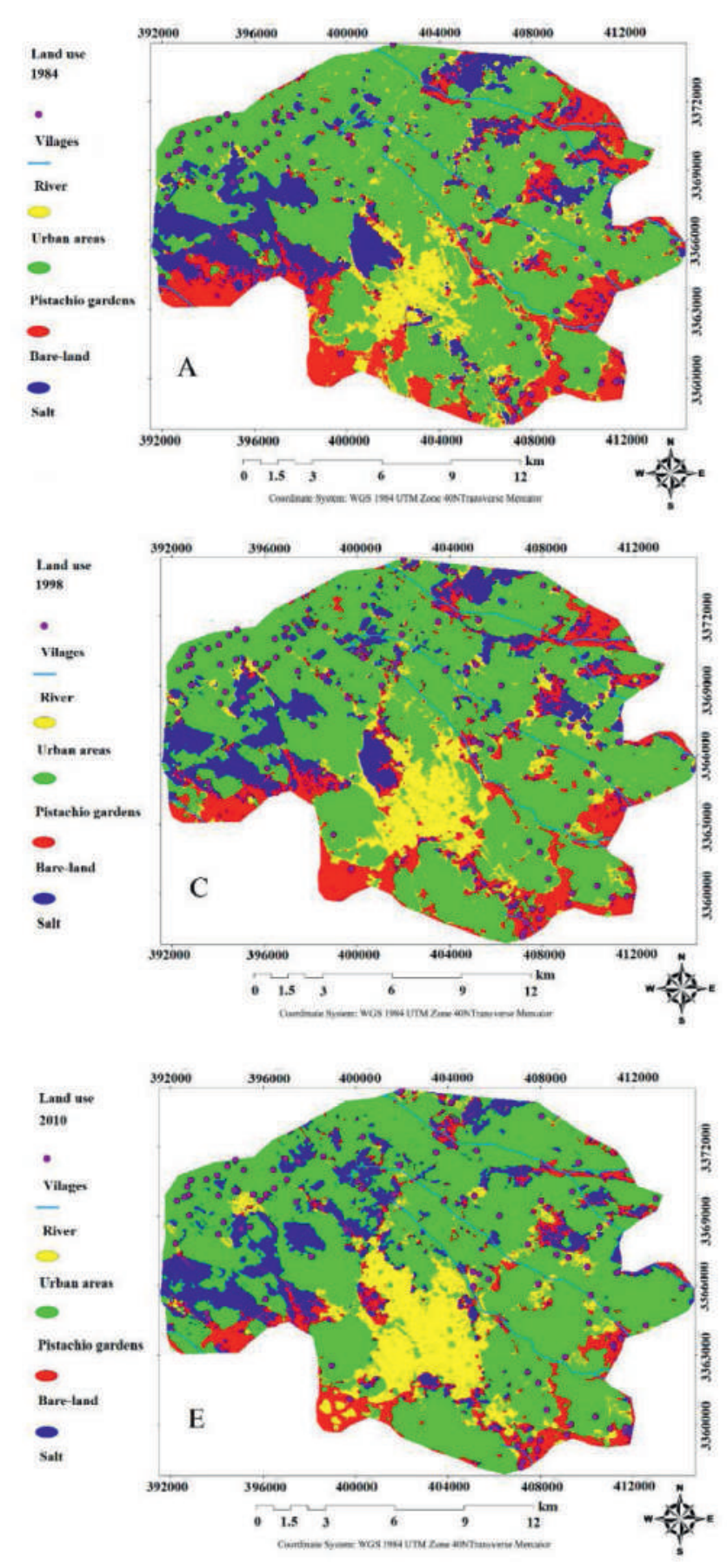
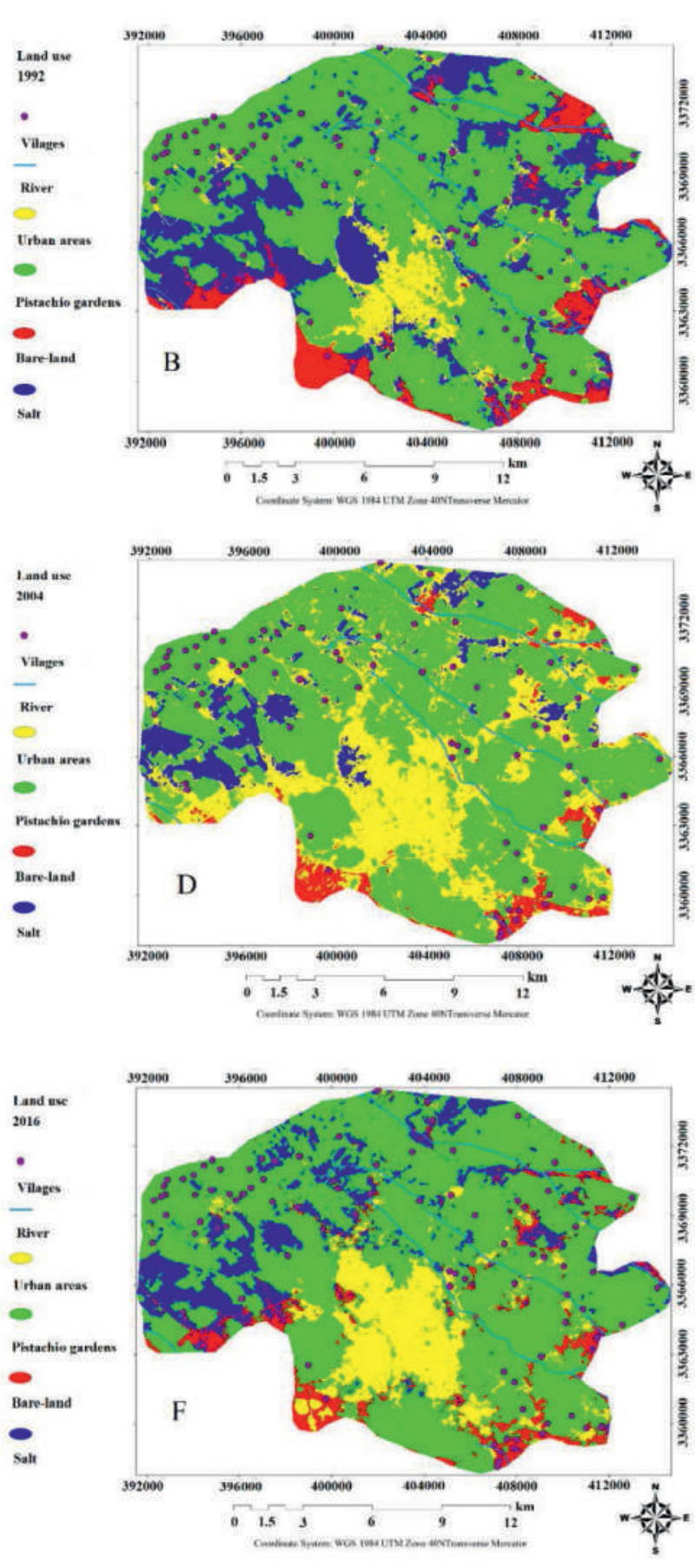

Fig. 3. Land use map for the years (A) 1984, (B) 1992, (C) 1998, (D) 2004, (E) 2010, and (F) 2016, using the maximum likelihood method

Рис. 3. Карты землепользования за годы: A - 1984, B - 1992, C- 1998, D - 2004, E- 2010 и F- 2016, используя метод максимального правдоподобия

was a major increase in the pistachio gardens that can be represented by an exponential growth model. In this study, the general trend of built-up areas has shown an increasing trend due to population expansion and its demand for infrastructure development. Significant change between 1986 and 2016 is that bare-land and salt areas are got converted in to Urban areas and pistachio gardens. From change analysis of land use between 1986 and 2016 it was observed that there is an increase in urban areas by $6.89 \%$ and decrease in bare-land by $13.43 \%$ and decrease in salt by $9.96 \%$. Pistachio gardens was found to increase by $14.31 \%$. Here the main change is that bare-land got converted to build up area.

\section{Selecting effective variables to predict land use changes}

It was tried to select variables that are effective on the land use changes and introduce into the model at this stage of the research. The main variables affecting the changes according to the characteristics of the region can be distance from the road, distance from the river, slop, and aspect $[21 ; 22]$. Therefore, to enter the variables mentioned land changing modeler, it is necessary them to be mapped out (Fig. 4). 
The pattern of change in surface area of land use in different periods in ha

Table 2 / Таблиия 2

Закономерность изменения площади поверхности землепользования в разные периоды, в га

\begin{tabular}{|c|c|c|c|c|c|c|}
\hline $\begin{array}{c}\text { Сlass name } \\
\text { Класс }\end{array}$ & 1986 & 1992 & 1998 & 2004 & 2010 & 2016 \\
\hline $\begin{array}{c}\text { Urban areas } \\
\text { Урбанизирован- } \\
\text { ные территории }\end{array}$ & 2875.40 & 3144.19 & 3715.56 & 3988.23 & 4054.87 & 4722.40 \\
\hline $\begin{array}{c}\text { Pistachio gardens } \\
\text { Фисташковые } \\
\text { садьь }\end{array}$ & 13413.15 & 14569.91 & 15541.48 & 15958.25 & 16741.01 & 16831.62 \\
\hline $\begin{array}{c}\text { Ваге-land } \\
\text { Голая земля }\end{array}$ & 5817.25 & 3758.38 & 3058.87 & 2910.87 & 2795.1 & 2219.58 \\
\hline $\begin{array}{c}\text { Salt } \\
\text { Соль }\end{array}$ & 5678.48 & 5311.80 & 4468.37 & 3926.93 & 3193.3 & 3010.68 \\
\hline
\end{tabular}
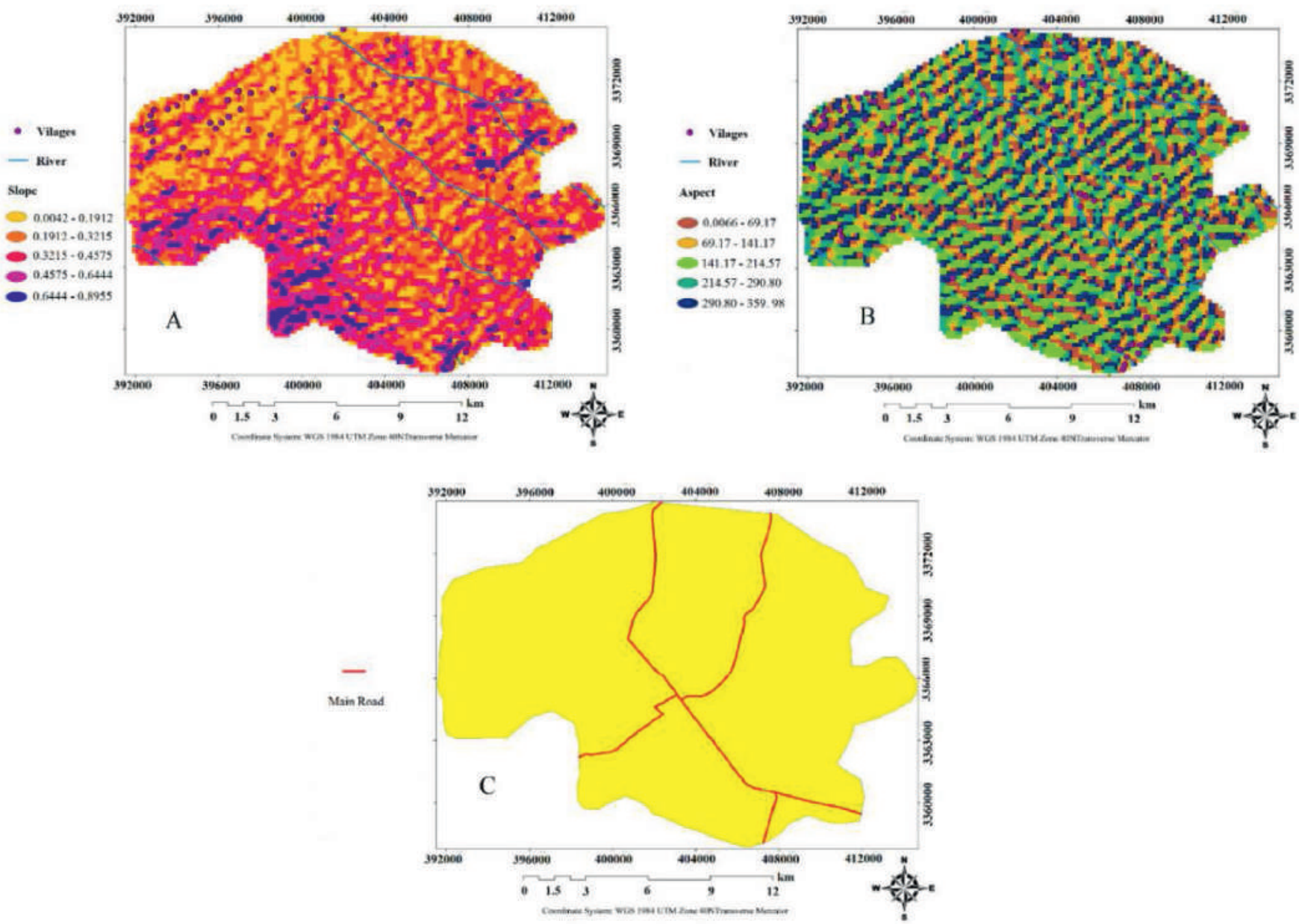

Fig. 4. The effective variables maps on prediction (A) Slope and rivers, (B) Aspect, and (C) Roads

Puc. 4. Эффективные переменные прогноза: $A$ - уклон и реки, $B$-аспект и $C$-дороги

\section{Land use change monitoring}

It is possible to analyze and map land use changes over a period of times using land-change modeler tools. It is first necessary to enter the land use maps related to the first and the last periods of the course in order to achieve this goal. Therefore, the land use maps prepared of satellite images that had vector-based structure entered into the IDRISI software and their structure with a cell size of 30 meters was converted to Raster. Then, the changes occurred during the period 1986-1992, 1992-1998, 19982004, 2004-2010 and 2010-2016 were detected and ana- lyzed using these maps (Fig. 5). At this stage, the potential for conversion of each class to other class was calculated based on input data including the distance from the road, the distance from the river, slope and aspect and land use maps derived from the maximum likelihood method. In other words, the probability that each pixel is changed in future was calculated. Many variables affecting change such as distance road, slope, and aspect during the time will be constant, so they have a static trait; some others, such as distance from the road and distance from residential areas, have a dynamic state and can be changed over 

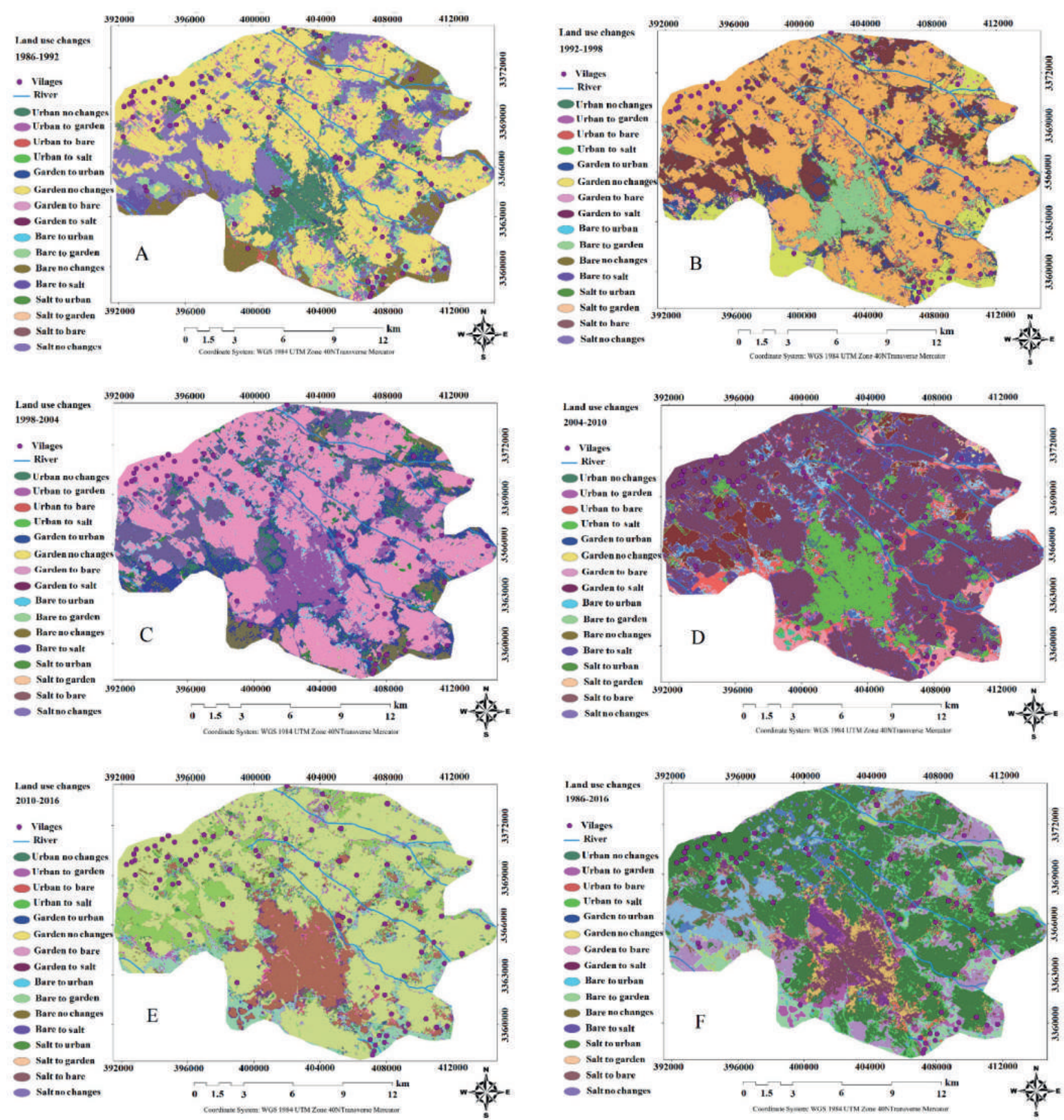

Fig. 5. Land use change map, (A) between 1982 and 1992, (B) between 1992 and 1998, (C) between 1998 and 2004, (D) between 2004 and 2010, (E) between 2010 and 2016, and (F) between 1982 and 2016

Pис. 5. Карты смены землепользования: A - в период с 1982 по 1992 год, В - в период между 1992 и 1998, C-между 1998 и 2004, $D$-между 2004 и 2010, E- в период между 2010 и 2016 и F- в период между 1982 и 2016 годами

the course of time, in fact, expand over the time, when new roads are built, and distance from roads also changes. In the LCM program, two methods have been predicted for modeling the Conversion potential: logistic regression and artificial neural networks. While the logistic regression method performs the potential of converting each use to another use separately, the artificial neural network method, in addition, is able to group the potential of converting sets of uses into other uses in a set of sub-models, or even can model and calculate the potential of convert- ing all uses to other uses in a single sub-model. In this research, the input variables of slope, aspect and land use map of existing as static and variables of distance from the road and the distance from the river margin were entered as a dynamic and the potential of converting all land uses were modeled using artificial neural networks method and logistic regression. So, using the LCM tools, the land use prediction map of 2022 was prepared (Fig. 6). It can be seen, a lot of changes will occur in classes in future.

The significant change occurred in land use between 


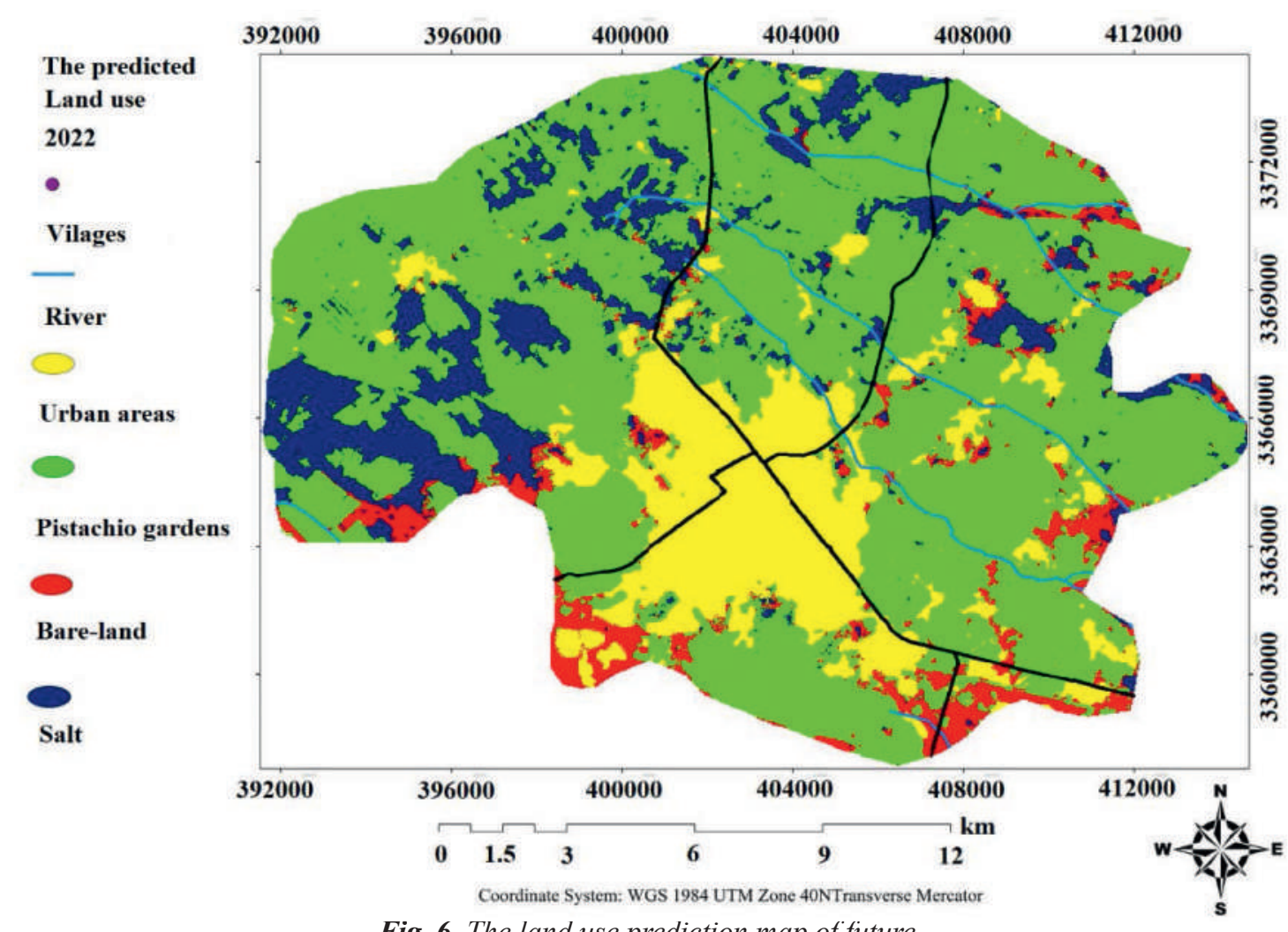

Fig. 6. The land use prediction map of future

Puс. 6. Карта прогнозирования землепользования будущего

1986 and 2022 is that conversion of bare-land, and salt in to urban area and Pistachio garden. This is mainly due to housing and infrastructure development that are already taken place and going to take place because of the development of main city of northern part of Kerman province. These changes will definitely have adverse impacts on the urban environment and proper planning and environmental management plans are necessary to mitigate these effects. This rapid and massive conversion of bare-land and salt in to urban area may have serious environmental impacts unless proper environmental management plans were implemented for the urban area.

\section{Conclusion}

The purpose of this study was to recognize a trend for land use changes that occurred in the last thirty years. To predict future changes, Landsat imagery and GIS tech-

\section{REFERENCES:}

1. Singh A. Review article digital change detection techniques using remotely-sensed data. International journal of remote sensing. 1989; 10(6): 989-1003.

2. Bella KP, Irwin EG. Spatially explicit microlevel modelling of land use change at the rural-urban interface. Agricultural Economics. 2002; 27(3): 217-32.

3. Shalaby A, Ghar MA, Tateishi R. Desertification impact assessment in Egypt using low resolution satellite data and GIS. International journal of environmental studies. 2004; 61(4): $375-83$.

4. Song X-P, Sexton JO, Huang C, Channan S, Townsh- niques were used. Land use images are developed in IDRISI and the future land use image was predicted using Land Change Modeller of IDRISI software. Also, the applicability of the LCM tools was investigated in our study. It was concluded that the study area has undergone a very intense land use change as a result of development plans either agricultural or urbanization. A significant increase in urban settlements has taken place as well as a great increase in agricultural land. According to the trend of change, the largest change was related to pistachio gardens class about $12.76 \%$; which indicated the most changes in land use classes. So, if the conditions do not change, the amount of agricultural use will increase, which this can create significant problems such as destructive environmental consequences followed by the lack of groundwater resources in the study area.

end JR. Characterizing the magnitude, timing and duration of urban growth from time series of Landsat-based estimates of impervious cover. Remote Sensing of Environment. 2016; 175: 1-13.

5. Weng Q. Modeling urban growth effects on surface runoff with the integration of remote sensing and GIS. Environmental management. 2001; 28(6): 737-48.

6. Yang L, Xian G, Klaver JM, Deal B. Urban land-cover change detection through sub-pixel imperviousness mapping using remotely sensed data. Photogrammetric Engineering \& Remote Sensing. 2003; 69(9): 1003-10. 
7. Asner GP, Alencar A. Drought impacts on the Amazon forest: the remote sensing perspective. New phytologist. 2010; 187(3): 569-78.

8. Jeyaseelan A. Droughts \& floods assessment and monitoring using remote sensing and GIS. Satellite remote sensing and GIS applications in agricultural meteorology. 291: World Meteorol. Org. Dehra Dun, India. Geneva, Switz; 2003.

9. Thomas RF, Kingsford RT, Lu Y, Hunter SJ. Landsat mapping of annual inundation (1979-2006) of the Macquarie Marshes in semi-arid Australia. International Journal of Remote Sensing. 2011; 32(16): 4545-69.

10. Renza D, Martinez E, Molina I. Unsupervised change detection in a particular vegetation land cover type using spectral angle mapper. Advances in Space Research. 2017; 59(8): 2019-31.

11. Shalaby A, Tateishi R. Remote sensing and GIS for mapping and monitoring land cover and land-use changes in the Northwestern coastal zone of Egypt. Applied Geography. 2007; 27(1): 28-41.

12. Zare M, Panagopoulos T, Loures L. Simulating the impacts of future land use change on soil erosion in the Kasilian watershed, Iran. Land Use Policy. 2017; 67: 558-72.

13. Mas JF, Flores JJ. The application of artificial neural networks to the analysis of remotely sensed data. International Journal of Remote Sensing. 2008; 29(3): 617-63.

14. Derakhshani R, Mehrabi A. Spatial association of copper mineralization and faults/fractures in Southern Part of Central Iranian volcanic belt. Trends in Applied Sciences Research. 2009; 4(3): 133-47.
15. Derakhshani R, Mehrabi A. Geologically-constrained fuzzy mapping of porphyry copper mineralization potential, Meiduk district, Iran. Trends in Applied Sciences Research. 2009; 4(4): 229-40.

16. Mehrabi A, Derakhshani R. Generation of integrated geochemical-geological predictive model of porphyry- $\mathrm{Cu}$ potential, Chahargonbad District, Iran. Geochimica Et Cosmochimica Acta. 2010; 74(12): A694-A.

17. Mirzaie A, Bafti SS, Derakhshani R. Fault control on $\mathrm{Cu}$ mineralization in the Kerman porphyry copper belt, SE Iran: A fractal analysis. Ore Geology Reviews. 2015; 71: 237-47.

18. Abbasnejad A, Abbasnejad B, Derakhshani R, Sarapardeh AH. Qanat hazard in Iranian urban areas: explanation and remedies. Environmental Earth Sciences. 2016; 75(19): 1306.

19. ClarkLabs. IDRISI Andes. Idrisi GIS and image processing software. Clark University, 950 Main St., Worcester MA 01610 USA2015.

20. Jin S, Yang L, Danielson P, Homer C, Fry J, Xian G. A comprehensive change detection method for updating the National Land Cover Database to circa 2011. Remote Sensing of Environment. 2013; 132: 159-75.

21. Hilbert DW, Ostendorf B. The utility of artificial neural networks for modelling the distribution of vegetation in past, present and future climates. Ecological modelling. 2001; 146(1-3): 311-27.

22. Maithani S, Jain R, Arora M. An artificial neural network based approach for modeling urban spatial growth. ITPI Journal. 2007; 4(2): 43-51.

\section{СВЕДЕНИЯ ОБ АВТОРАХ / Information about authors:}

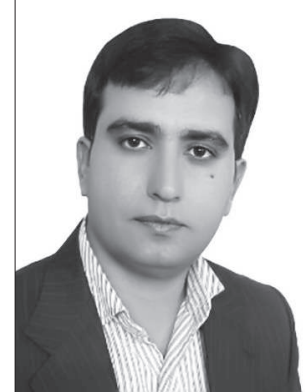

Ali MEHRABI - Doctor of Geology, Assistant Professor, Department of Geography and Urban Planning, Shahid Bahonar University of Kerman, Kerman, Iran

Ph.: +98 9131934256;

Mehrabi@uk.ac.ir

Али МЕХРАБИ - доктор геологических наук, дочент. Кафедра географии и градостроительства, Университет Шахида Бахонара, Керман, Иран

Тел.: +989131934256; Mehrabi@uk.ac.ir

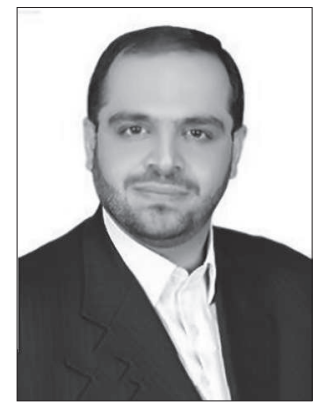

S. Ali ALMODARESI - Doctor of Geomorphology, Associate Professor Department of GIS \& RS, Yazd Branch, Islamic Azad University. Yazd, Iran

Ph.: +98 9131526455;

almodaresi@iauyazd.uk.ac.ir

С. Али АЛМОДАРЕСИ - доктор геоморфологических наук, доиент, Отделение ГИС и РС, филиал Язд, Исламский Университет Азад. Язд, Иран

Тел.: +989131526455; almodaresi@iauyazd.uk.ac.ir

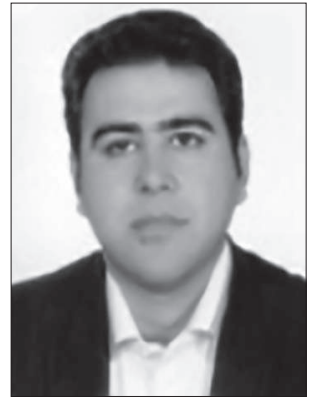

Mostafa KHABAZI - Doctor of Geomorphology, Assistant Professor, Department of Geography and Urban Planning, Shahid Bahonar University of Kerman, Kerman, Iran

Ph.: +98 9132054560;

mostafakhabazi@uk.ac.ir

Мостафа ХАБАЗИ - доктор гео-

Кафедра географии и градостроительства,

Университет Шахида Бахонара, Керман, Иран

Тел.: +989132054560; mostafakhabazi@uk.ac.ir

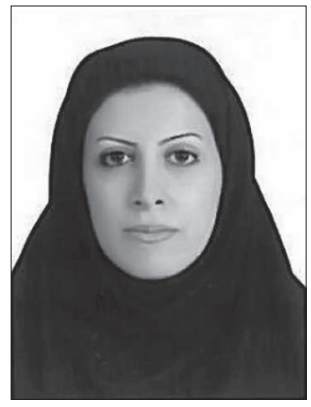

Maryam NOHESARA - PhD Student of Geography and Urban Planing,

Department of Geography and Urban planning, Yazd Branch, Islamic Azad University, Yazd, Iran

Ph.: +98 9909134560;

maryamnohesara@yahoo.com

Марьям НОЕСАРА - аспирант.

Кафедра географии и градостроиверситет Азад, Язд, Иран тельства, филиал Язд, Исламский УниТел.: +98 9909134560; maryamnohesara@yahoo.com 
Reza DERAKHSHANI - Doctor of Geology, Associate Professor, Department of Geology, Shahid Bahonar University of Kerman, Kerman, Iran \& Department of Earth Science, Utrecht University, Utrecht, The Netherlands

Ph.: +31 30 2535039;

r.derakhshani@uu.nl

Реза ДЕРАХШАНИ - доктор геологических наук, доиент кафедры геологии, Университет Шахида Бахонара, Керман, Иран; Департамент наук о Земле, Утрехтский Университет, Утрехт, Нидерландь

тел.: +31302535039; r.derakhshani@uu.nl

\title{
МОНИТОРИНГ ИЗМЕНЕНИЙ В ЗЕМЛЕПОЛЬЗОВАНИИ НА ПРОТЯЖЕНИИ 30 ЛЕТ И ПРОГНОЗИРОВАНИЕ БУДУЩИХ ИЗМЕНЕНИЙ С ИСПОЛЬЗОВАНИЕМ МНОГОКРАТНЫХ СНИМКОВ ЛАНДШАФТА И ИНСТРУМЕНТОВ МОДЕЛИРОВАНИЯ ИЗМЕНЕНИЙ В ГОРОДЕ РАФСАНДЖАН (ИРАН)
}

\author{
${ }^{1}$ Али Мехраби \\ ${ }^{1}$ Мустафа Хабази, \\ ${ }^{2}$ С. Али Альмодареси, \\ ${ }^{3}$ Марьям Ноесара \\ 4,5 Реза Дерахшани* \\ ${ }^{1}$ Кафедра географии и градостроительства, Керманский университет Шахида Бахонара, Керман, Иран \\ ${ }^{2}$ Кафедра ГИС и РС, филиал Язд, Исламский университет Азад. Язд, Иран \\ ${ }^{3}$ Кафедра географии и градостроительства, филиал Язд, Исламский университет Азад, Язд, Иран \\ ${ }^{4}$ Кафедра геологии, Керманский университет имени Шахида Бахонара, Керман, Иран \\ 5 Департамент Наук о Земле, Университет Утрехта, Утрехт, Нидерланды, е-mail: r.derakhshani@uи.nl
}

\section{DOI: $10.21177 / 1998-4502-2019-11-1-26-35$}

Целью данного исследования является прогнозирование и моделирование будущего изменения в расписании с использованием дистанционного зондирования и ГИС. Использовались многозональные спутниковые данные, полученные со спутников Landsat 5 (TM), 7 (ETM+) и 8 (OLI), за 1986, 1992, 1998, 2004, 2010 и 2016 годы соответственно. Метод контролируемой классификации применялся к многократным изображениям Landsat. Город Рафсанджан был разделен на четыре основных класса, включая городские районы, фисташковые сады, голые земли и соль. Анализ обнаружения изменений был проведен для сравнения количеств изменений класса землепользования между временными интервалами. Результаты показали как увеличение, так и уменьшение различных классов ЛУ с 1986 по 2016 год. В заключении указывается, что на протяжении исследуемого периода, городские районы и фисташковые сады увеличились на $6,89 \%\left(18.47\right.$ км$\left.^{2}\right)$ и $12.76 \%\left(34.18\right.$ км²$\left.^{2}\right)$, в то время, как голые земли и соль сократились на 13,43\% (35.97 км²) и 9,96\% (26.68 км²), соответственно. Для того чтобы предсказать будущие изменения в землепользовании на картах, мы использовали инструменты моделирования изменения Земли с программным обеспечением IDRISI. Следовательно, прогнозируемая карта землепользования 2022 года была подготовлена на основе тенденции изменения землепользования за 30 лет и эффективных переменных.

Ключевые слова: расширение городов, обнаружение изменений, дистанционное зондирование, геонауки, Керман.

\section{Литература}

1. Singh A. Review article digital change detection techniques using remotely-sensed data // International journal of remote sensing. 1989. 10(6). Pp. 989-1003.

2. Bella KP, Irwin EG. Spatially explicit microlevel modelling of land use change at the rural-urban interface // Agricultural Economics. 2002. 27(3). Pp. 217-32.

3. Shalaby A, Ghar MA, Tateishi R. Desertification impact assessment in Egypt using low resolution satellite data and GIS // International journal of environmental studies. 2004. 61(4). Pp. 375-83.

4. Song X-P, Sexton JO, Huang C, Channan S, Townshend JR. Characterizing the magnitude, timing and duration of urban growth from time series of Landsat-based estimates of impervious cover // Remote Sensing of Environment. 2016. 175. Pp. 1-13.

5. Weng Q. Modeling urban growth effects on surface runoff with the integration of remote sensing and GIS // Environmental management. 2001. 28(6). Pp. 737-48.

6. Yang L, Xian G, Klaver JM, Deal B. Urban land-cover change detection through sub-pixel imperviousness mapping using remotely sensed data // Photogrammetric Engineering \& Remote Sensing. 2003. 69(9). Pp. 1003-10.

7. Asner GP, Alencar A. Drought impacts on the Amazon forest: the remote sensing perspective // New phytologist. 2010. 187(3). Pp. 569-78.

8. Jeyaseelan A. Droughts \& floods assessment and monitoring using remote sensing and GIS. Satellite remote sensing and GIS applications in agricultural meteorology. World Meteorol. Org. Dehra Dun, India. Geneva, Switz., 2003. 291 p. 
9. Thomas RF, Kingsford RT, Lu Y, Hunter SJ. Landsat mapping of annual inundation (1979-2006) of the Macquarie Marshes in semi-arid Australia // International Journal of Remote Sensing. 2011. 32(16). 4545-69.

10. Renza D, Martinez E, Molina I. Unsupervised change detection in a particular vegetation land cover type using spectral angle mapper // Advances in Space Research. 2017. 59(8). Pp. 2019-31.

11. Shalaby A, Tateishi R. Remote sensing and GIS for mapping and monitoring land cover and land-use changes in the Northwestern coastal zone of Egypt // Applied Geography. 2007. 27(1). Pp. 28-41.

12. Zare M, Panagopoulos T, Loures L. Simulating the impacts of future land use change on soil erosion in the Kasilian watershed, Iran // Land Use Policy. 2017. 67. Pp. 558-72.

13. Mas JF, Flores JJ. The application of artificial neural networks to the analysis of remotely sensed data // International Journal of Remote Sensing. 2008. 29(3). Pp. 617-63.

14. Derakhshani R, Mehrabi A. Spatial association of copper mineralization and faults/fractures in Southern Part of Central Iranian volcanic belt // Trends in Applied Sciences Research. 2009. 4(3). Pp. 133-47.

15. Derakhshani R, Mehrabi A. Geologically-constrained fuzzy mapping of porphyry copper mineralization potential, Meiduk district, Iran // Trends in Applied Sciences Research. 2009. 4(4). Pp. 229-40.
16. Mehrabi A, Derakhshani R. Generation of integrated geochemical-geological predictive model of porphyry- $\mathrm{Cu}$ potential, Chahargonbad District, Iran // Geochimica Et Cosmochimica Acta. 2010. 74(12). A694-A.

17. Mirzaie A, Bafti SS, Derakhshani R. Fault control on $\mathrm{Cu}$ mineralization in the Kerman porphyry copper belt, SE Iran: A fractal analysis // Ore Geology Reviews. 2015. 71. Pp. 237-47.

18. Abbasnejad A, Abbasnejad B, Derakhshani R, Sarapardeh AH. Qanat hazard in Iranian urban areas: explanation and remedies // Environmental Earth Sciences. 2016. 75(19). P. 1306.

19. ClarkLabs. IDRISI Andes. Idrisi GIS and image processing software. Clark University, 950 Main St., Worcester MA 01610 USA2015.

20. Jin S, Yang L, Danielson P, Homer C, Fry J, Xian G. A comprehensive change detection method for updating the National Land Cover Database to circa 2011 // Remote Sensing of Environment. 2013. 132. Pp. 159-75.

21. Hilbert DW, Ostendorf B. The utility of artificial neural networks for modelling the distribution of vegetation in past, present and future climates // Ecological modelling. 2001. 146(1-3). Pp. 311-27.

22. Maithani S, Jain R, Arora M. An artificial neural network based approach for modeling urban spatial growth // ITPI Journal. 2007. 4(2). 43-51.

Статья поступила в редакциию 06.02.2019. 
${ }^{1}$ Кюль Е.В*. ${ }^{2}$ Езаов А.К., ${ }^{2}$ Канкулова Л.И.

\section{TЕОРЕТИЧЕСКИЕ ОСНОВЫ ГЕОЭКОЛОГИЧЕСКОГО МОНИТОРИНГА ГОРНЫХ ГЕОСИСТЕМ}

\section{УДК: $551.3+911.5$}

DOI: 10.21177/1998-4502-201911-1-36-43

В статье рассмотрены три этапа проведения мониторинга горных геосистем. Авторами определены основные принципы создания гидрографро- $u$ геоморфологического каркаса территории. Решены теоретические вопросы классификации опасных процессов в горных территориях, условий их образования и типов землепользования. Для создания мониторинговой сети горных геосистем приведены критерии распределения объектов мониторинга, а именно, участков образования ОПП - по очерæдности и периодичности обследования. Предложенная методика мониторинеа позволяет разработать меры, снижающие уровень воздействия процессов на горные геосистемы до приемлемого минимума.

\section{КЛЮЧЕВЫЕ СЛОВА:}

геоэкологический мониторине, опасные природные процессы, геосистемы, ландшафты, инвентаризация, паспортизация, ранжирование.

Статья поступила в редакцию 16.04.2018.
Введение. Для устойчивого и потенциально безопасного развития горной территории необходимо проведение геоэкологического мониторинга горных геосистем с учётом опасных природных процессов (ОПП), с одной стороны, и освоенности территории, с другой стороны [1]. Методика экологического мониторинга окружающей среды достаточно хорошо разработана в научной литературе [2-4]. Решению данного вопроса призвана послужить Единая государственная система экологического мониторинга (ЕГСЭМ) [3]. И хотя на каждой конкретной территории уже имеется ряд сетей наблюдений, они чаще всего принадлежат различным службам. Поэтому выбор управленческих решений затруднён и полученные по данным мониторинга прогнозы будут являться не совсем корректными.

В настоящее время необходим комплексный геоэкологический подход к мониторингу окружающей среды и как один из вариантов приведен в [5; 6].

Цель исследований: решение основных теоретических вопросов геоэкологического мониторинга горной части территории Кабардино-Балкарской Республики (КБР) на предмет изменения горных геосистем под воздействием природно-антропогенных факторов.

Постановка задачи исследований. При геоэкологическом мониторинге необходимо описать как можно больше компонентов окружающей среды и измерить максимальное число репрезентативных характеристик каждого из этих компонентов. При этом проводится площадная оценка изменения геосистем при помощи ГИС-технологий. При ведении геоэкологического мониторинга для выявления эталонных геосистем необходимо составлять их структурнодинамические ряды с учетом их возраста, направлений, трансформаций для выделения критериев формирования устойчивых геосистем с высоким биопотенциалом (генетическим разнообразием). Особенно это важно для особо охраняемых природных территорий (ООПТ). На предварительном камеральном этапе мониторинга оцениваются условия и факторы образования ОПП. На полевом этапе на основе инвентаризации и паспортизации выделяются участки образования ОПП с различными степенями подверженности территории опасным процессам и нарушенности ландшафтов. На заключительном этапе проводится ранжирование участков по степени природной опасности и устойчивости к влиянию опасных процессов и антропогенной нагрузке на ландшафт.

\section{Методы и материалы исследований}

Основной метод исследований: фото-космо-картографический. Дешифрирование фото- и космоснимков выполнялось с целью выделения участков ландшафтов с различной степенью трансформации опасными природными процессами. Для целей ландшафтного дешифрирования использовались многозональные снимки. Обработка фотоснимков производилась в Программе Multi Spec [7]. Для повышения достоверности распознавания объектов при дешифрировании фото- и космоснимков и отслеживания динамики развития

${ }^{1}$ Кабардино-Балкарский научный центр Российской Академии наук, Центр географических исследований, 360002, Нальчик, Россия, elenakyul@mail.ru

${ }^{2}$ Кабардино-Балкарский государственный аграрный университет им. В.М. Кокова, 360000, Нальчик, Россия 
процессов применялся способ сравнительного дешифрирования разновременных изображений территории, полученных с различными временными интервалами и в разные сезоны года.

Результаты исследований. Рассмотрим основное понятие «ландшафт» как природно-территориальный комплекс (ПТК) любого ранга - «совокупность взаимообусловленных и взаимосвязанных предметов и явлений природы, предстающих перед нами в образе тех или иных исторически сложившихся непрерывно развивающихся географических комплексов» [4]. Синонимом ПТК являются термины: природный комплекс, природный геокомплекс и природная геосистема. В случае горных ландшафтов большую роль играют ОПП, которые оказывают заметное влияние, как на отдельные компоненты ландшафта, так и на весь ландшафт в целом.

Определим на каждом этапе мониторинга основные методы, способы и приёмыл.

1-й этап. Камеральный. Для создания гидро-графо- геоморфологического каркаса территории применяется несколько основных принципов деления территории.

1. По вертикали. Гипсометрическое (высотное) деление территории (5 градаций): а) менее 1000 м, маловысотные горы; б) 1000-2000 м, средне- и низковысотные горы; в) 2000-3000 м, высокие и средневысокие горы; г) 3000- 5000 м, высокие горы; д) более 5000 м, высочайшие горы.

2. По горизонтали. Гидрографическое деление территории (по речным бассейнам): по порядку, начиная от главного (бассейн 1-го порядка) и далее по принципу от главного к частному - 2-го, 3-го, 4-го, 5-го порядка и т.д.; водосборной площади; длине водотока.

Характеристики речных бассейнов берутся из Государственного водного реестра [8], что позволяет уточнить некоторые их данные и дать более точную привязку. В результате по комплексу показателей выделяются гидрографические районы (рис. 1).

3. По широте. Геоморфологическое деление терpuтории. При его проведении за основу взята схема ландшафтно-геоморфологического районирования Северного Кавказа, предложенная Кюль Е.В. в 2004 г. [6] для районирования лавинной опасности КБР на основе палеогеографического принципа, позволяющего выделить типы морфоструктур разного порядка и возраста (рис. 2).

Кроме того, при проведении мониторинга для оценки влиянии процессов на ландшафты необходимо выделить типы ОПП. При этом используется Общая генетическая классификация экзогенных геологических опасностей А.И. Шеко [9]: С учётом особенностей распространения тех или иных типов ОПП на исследуемой горной территории это следующие группы ОПП (взяты из Классификации А.И. Шеко [9]): 1) группа II. Группы опасностей, обусловленные энергией рельефа (силой тяжести). Подгруппы склоновые. Оползни. Обвалы. Осыпи. Ледники. Лавины; 2) группа III. Группы опасностей, обусловленные поверхностными водами. Подгруппы русловые. Сели.

Степень изменения ландшафтов настолько велика, что в результате этого в горной местности формируются природные лавинные (ПЛК), селевые (ПСК) и другие комплексы. Каждый ландшафт оценивается по сумме условий и факторов образования ОПП,

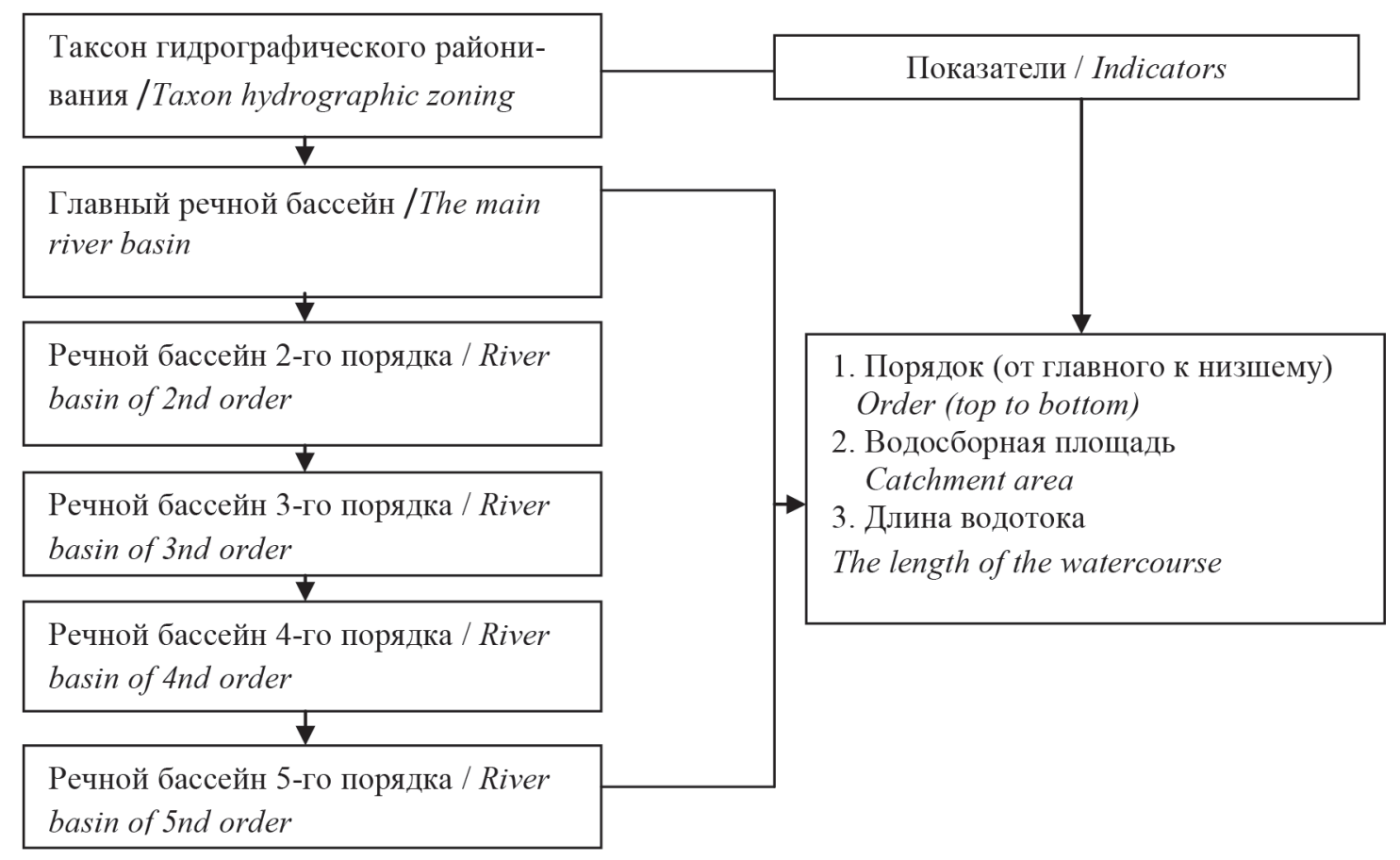

Puc. 1. Схема гидрографического (бассейнового) районирования

Fig. 1. The scheme of the hydrographic (basin) zoning 


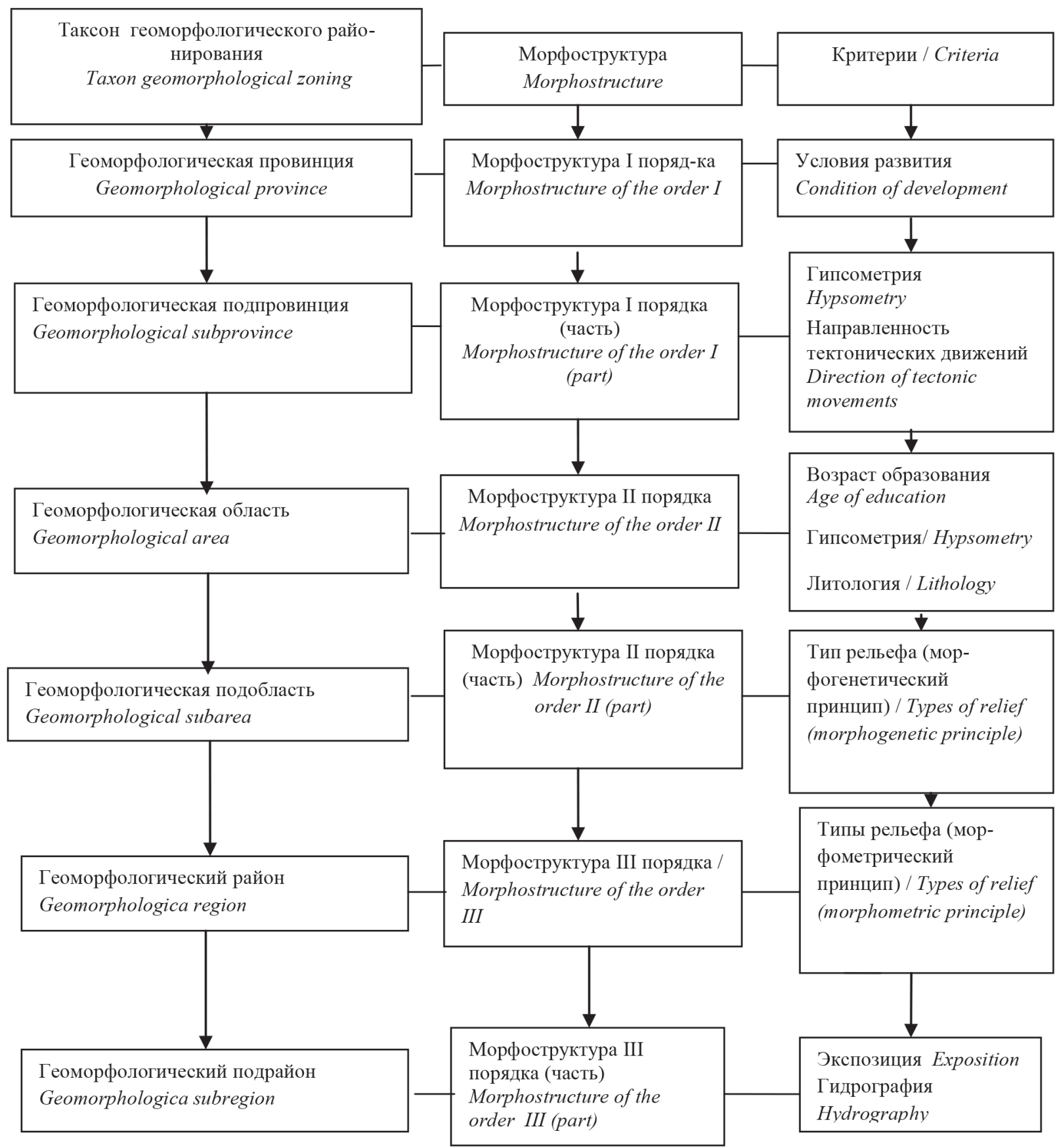

Pис. 2. Схема геоморфологического районирования

Fig. 2. The scheme of geomorphological zoning

а также типам процессов и землепользования. При этом применяется способ ведущеего показателя, который является на данный момент времени причиной схода опасного процесса. Критерий выбора «ведущего показателя» - критические значения того или иного, например, условия, приводящие к сходу того или иного процесса.

Для покомпонентной оценки ландшафта разработана Классификация условий образования ОПП: здесь выделяются постоянные (эндогенные и экзогенные) и переменные (метеорологические) условия образования [6]. При этом при проведении собственных исследований [5-6] подтвердились выводы других учёных [10-15], что наиболее подвержены воздействию опасных процессов такие компоненты ландшафта, как рельеф, растительность, почвы, поверхностные воды, в меньшей степени - климат.

Факторы же образования опасных проиессов это комплекс природно-климатических условий с определёнными критическими значениями на данный момент времени, приводящий к их образованию. Например, для снежных лавин ведущим условием и фактором, отделяющим потенциальный опасный процесс от фактического, служит снежный покров (его структура и состояние). Здесь работает принцип: чем больше факторов, тем точнее оценка.

Освоенность территории определяется по типу землепользования («...форме распоряжения землей 
с целью извлечения из земли полезных свойств или дохода» [4; 16-17]). Для этого разработана классификация ландшафтов по типу землепользования: сельскохозяйственный, селитебный, промышленный, инженерно-коммуникационный, рекреационный, природоохранный, историко-культурный, лесной, водный и земли запаса. На основе данной классификации выделяются районы с различными типами землепользования. В дальнейшем учитывается влияние освоенности на активизацию опасных процессов.

2-й эman. Полевой. По результатам площадной оценки на основе инвентаризации проводится в ходе паспортизации GPS-съёмка ландшафтов, наиболее подверженных опасным процессам. При этом оценивается степень трансформации ландшафта этими процессами (таблица) [4; 18-20].

3 этап. Заключительный. По результатам инвентаризации и паспортизации создаётся мониторинго- вая сеть. Здесь проводится распределение основных единиц образования опасных процессов (например, для снежных лавин это лавиносборы) по очерёдности и периодичности обследования. Для этого выделяются градации элементарных единиц по 2-м параметрам: размер схода ОПП (по объёму выноса сносимого материала, м $^{3}$ ) и класс опасности народно-хозяйственных объектов в зоне схода ОПП.

Градации ОПП по размеру схода: с небольшим объемом выноса (до 10 тыс. м³), средним (10-100 тыс. м $^{3}$ ) и большим (100-500 тыс. м $^{3}$ ) катастрофическим (более 500 тыс. м³). Классы же опасности (4) хозяйственных (опасных производственных) объектов выделяются в соответствии с Федеральным законом «О промышленной безопасности опасных производственных объектов» 116-Ф3 [4].

Далее создаётся мониторинговая сеть геосистем, где элементарные единицы образования опасных процессов и хозяйственные объекты в зоне их дей-

\section{Параметры оценки воздействия ОПП на отдельные компоненты ландшафта}

Parameters for assessing the impact of AKI on individual components of the landscape

\begin{tabular}{|c|c|c|}
\hline № & $\begin{array}{l}\text { Компонент ландшафта } \\
\text { Landscape component }\end{array}$ & $\begin{array}{c}\text { Воздействие ОПП (на примере снежных лавин) } \\
\text { Impact of HNP(on the example of avalanches) }\end{array}$ \\
\hline 1. & Рельеф / Relief & $\begin{array}{l}\text { Количество элементарных единиц образования ОПП } \\
\text { The number of elementary units of education HNP }\end{array}$ \\
\hline \multirow{5}{*}{2.} & $\begin{array}{l}\text { Растительность: } \\
\text {-проективное покрытие; } \\
\text { Vegetation: } \\
\text {-projective cover } \\
\end{array}$ & $\begin{array}{l}\text { Проективная площадь покрытия лавиносбора, \% } \\
\text { The projective coverage of avalanche collections, \% }\end{array}$ \\
\hline & $\begin{array}{l}\text {-состав пород } \\
\text { composition of rocks }\end{array}$ & $\begin{array}{l}\text { Замена первичной растительности на вторичную,\% } \\
\text { Replacement of primary vegetation on the secondary,\% }\end{array}$ \\
\hline & -состояние / condition; & Механические повреждения,\% / Mechanical damage,\% \\
\hline & -инверсия / inversion & $\begin{array}{l}\text { Наличие растений-биоиндикаторов из другого ландшафтного пояса } \\
\text { Presence of plants-bioindicators of landscape from a different belt }\end{array}$ \\
\hline & -другое / another & $\begin{array}{l}\text { Запаздывание фаз растительности, временной период / Delay of the } \\
\text { phases of vegetation, the time period }\end{array}$ \\
\hline \multirow{5}{*}{3.} & $\begin{array}{l}\text { Почвы: } \\
\text {-проективное покрытие } \\
\text { Soils: } \\
\text {-projective cover; }\end{array}$ & $\begin{array}{l}\text { Наличие первичных почв, \% } \\
\text { The Presence of primary soil, \% }\end{array}$ \\
\hline & -состав / composition & Изменение механического состава / Change in mechanical composition; \\
\hline & \multirow{2}{*}{-состояние / condition } & $\begin{array}{l}\text { Степень нарушенности горизонтов почв } \\
\text { The Degree of disturbance of soil horizons }\end{array}$ \\
\hline & & $\begin{array}{l}\text { Изменение температуры почв, град } \\
\text { Changes in soil temperature, degrees. }\end{array}$ \\
\hline & -инверсия / inversion & Смешивание почв разного типа / Mixing of soils of different types \\
\hline 4. & $\begin{array}{l}\text { Климат: } \\
\text { - температура воздуха } \\
\text { Climate: } \\
\text { - air temperature } \\
\end{array}$ & $\begin{array}{l}\text { Изменение температуры воздуха,град. } \\
\text { The change in temperature, degrees }\end{array}$ \\
\hline 5. & $\begin{array}{l}\text { Воды поверхностные: } \\
\text {-гидрологический режим } \\
\text { Surface waters: } \\
\text {-hydrological regime }\end{array}$ & $\begin{array}{l}\text { Изменение режима: } \\
\text {-скорость течения } \\
\text { Change of the regime: } \\
\text {-flow rate }\end{array}$ \\
\hline
\end{tabular}

Примечание: степень воздействия ОПП на два последних компонента практически не изучена и требует дополнительных специальных исследований / Note: the impact of HNP on the latter two components is virtually unexplored and requires further ad hoc studies. 
ствия делятся на 4 класса (от 1-го, где расположены объекты, которые обследуются в первую очередь, несколько раз в год, и далее).

Создание такой сети позволяет наиболее полно отслеживать сход опасных процессов, уточнять и дополнять данные для представления, в дальнейшем, материалов в виде Атласов, Кадастров и Баз данных. Такое картографическое обеспечение даёт возможность провести численную оценку природной опасности на настоящий момент времени.

Выводы. Предложенная методика геоэкологического мониторинга даёт возможность провести комплексную площадную оценку подверженности территории опасным процессам с учётом освоенно- сти. При этом выделяются геосистемы с высокой степенью опасности, которые, в дальнейшем, должны изыматься из землепользования. Некоторые же виды хозяйственной деятельности, приводящие к активизации того или иного типа процесса, должны быть запрещены.

Регулирование, с одной стороны, степени влияния опасных процессов на природную среду, а с другой стороны, степени влияния освоенности территории на эти процессы, позволит выбрать оптимальный вариант мероприятий по борьбе с опасными процессами. При таком геоэкологическом подходе территория приобретает статус «потенциально безопасной».

Апробация методики мониторинга проводится на территории Кабардино-Балкарской Республики в рамках выполняемых работ по бюджетной тематике Центра географических исследований КБНЦ PAH / The monitoring methodology testing is carried out on the territory of the Kabardino-Balkar Republic (CBD) within the framework of the work on the budget theme of the Center for Geographical Studies of the Kabardino-Balkar Scientific Center of $R A S$.

\section{КРИТЕРИИ АВТОРСТВА / Contribution:}

Кюль Е.В. - разработала теоретическое обоснование мониторинга, написала рукопись и несет ответственность за плагиат; Езаов А.К. - проанализировал и обобщил данные по проблеме исследований; Канкулова Л.И. - выполнила оформление и корректировку рукописи.

Kyul E. $\boldsymbol{V}$. - developed the theoretical basis of monitoring, wrote the manuscript and is responsible for plagiarism; Ezaov A. K. - analyzed and summarized data on the problem of research; Kankulova L. I. - executed the design and correction of the manuscript.

КОНФЛИКТ ИНТЕРЕСОВ / Conflict of interest:

Авторы заявляют об отсутствии конфликта интересов / The authors declare no conflict of interest.

\section{ЛИТЕРАТУРА:}

1. Гуня А. Н. Модернизация и устойчивое развитие горных территорий // Устойчивое развитие горных территорий. T.8. N 4. C. 281-288. DOI: 10.21177/1998-4502-2016-8-4-281288.

2. Акселевич В. И. Система геоэкологического мониторинга и его организация в интересах обеспечения безопасности мегаполисов // Международный журнал прикладных и фундаментальных исследований. 2015. N 8-1. С. 70-74.

3. Гинко В. И., Тараров А. Г. Система экологического мониторинга в управлении экологическим риском // Современные проблемы науки и образования. 2015. N 3. С. 328.

4. Жердев В. Н., Орлов А. Н. Геоэкологический мониторинг: исследование контролируемых параметров особо охраняемых территорий // Вестник ВГУ. География. Геоэкология. N 1. 2000. С. 139-141.

5. Кюль Е. В., Борисова Н. А. Геоэкологический мониторинг: создание мониторинговой сети по результатам инвентаризации и паспортизации // Материалы IV Bсероссийской конференции «Экология. Экономика. Информати- ка. Системный анализ и моделирование экономических и экологических систем, Абрау-Дюрсо, 11-17 сентября 2016. C.145-149.

6. Кюль Е. В. Методологические основы оценки влияния снежных лавин на горные ландшафты // Сборник трудов III Международного симпозиума «Физика, химия и механика снега», часть 2. Южно-Сахалинск, 2-6 октября 2017. C. 62-66.

7. GIS-Lab: Обработка многозональных космоснимков. Электронный ресурс: http: // gis-lab/info/qa/multispec-sat. htm. (Дата обращения 06.04.2018)

8. Государственный водный реестр. Электронный реcypc: www.textual.ru >gvr/. (Дата обращения 06.04.2018)

9. Анисимова Н. Г., Викторов А. С., Дзецкер Е. С., Зорина Е. Ф., Крупдеров В. С., Кутепов В. М., Ларионов Г. А., Литвин Л. Ф., Рагозин А. Л., Осипов В. И., Сафьянов Г. А., Чалов Р. С., Шеко А. И. Природные опасности России. Экзогенные геологические опасности. Том 3. М.: Издательство «Крук», 2002. 348 с. 
10. Cenderelli D. A., Wohl E. E. Flow hydraulics andgeomorphic effects of glacial-lake outburst floods in the Mount Everest region. Nepal // Earth Surface Processes and Landforms, 2003. Pp. 385-407.

11. Donald Bedunah; Rick Graetz; Alexey Gunya; Spike Hampson; Marc S. Hendrix; Ardeshir Kia; Merhdad Kia; Alex Klaits; James W. Sears. Discovering Central Asia: Its History, Geography, and Politics. Co-authors: The University of Montana Press, 2012. 382 p.

12. Gentili R., Armiraglio S., Sgorbati S., Baroni C. Geomorphological disturbance affects ecological driving forces and plant turnover along an altitudinal stress gradient on alpine slopes // Plant Ecology . 2013. No 214. Pp. 571-586.

13. Patten R. S., Knight D. H. Snow Avalanches and Vegetation Pattern in Cascade Canyon. Grand Teton National Park, Wyoming U.S.A. // Arctic, Antarctic and Alpine. 1994. No 26. Pp. 35-41.

14. Sinickas A., Jamieson B. Validating the Space-Time model for infrequent snow avalanche events using field observations from the Columbia and Rocky Mountains, Canada // Arctic, Antarctic and Alpine Research. 2016. Vol. 48, no 1. Pp. 177-197.

15. Rixen Ch., Haag S., Kulakowski D., Bebi P. Natural ava- lanche disturbance shapes plant diversity and species composition in subalpine forest belt // Journal of Vegetation Science. 2007. Vol. 18. Pp. 735-742.

16. Аксёнова Е. Г.,Гаранова М. В. Актуальные проблемы землеустройства и кадастра // Экономика и экология территориальных образований. 2017. N 1. С. 93-95.

17. Хажметов Л. М., Езаов А. К., Сасиков А. С. Стационарный мониторинг ресурсовоспроизводящих процессов агромелиоландщафта // Материалы Международной (заочной) научно-практической конференции «Вектор развития современной науки». София, 27 ноября 2016. С. 42-45.

18. Гуня А. Н. Социально-ориентированные концепции и подходы в исследовании горных территорий Кавказа и обеспечении устойчивого развития // Устойчивое развитие горных территорий. 2015. N3 (25). С. 15-22.

19. Хаширова Т. Ю., Гергов А. Р., Георгиева М. А., Акбашева Г. А. Применение информационных технологий при оценке экологической стабильности горных и предгорных ландшафтов // Фундаментальные исследования. 2017. N 7. C. $83-87$.

20. Северский И. В., Благовещенский В. П. Оценка лавинной опасности горной территории. Алма-Ата: Наука, 1983. $219 \mathrm{c}$

СВЕДЕНИЯ ОБ АВТОРАХ / Information about authors:

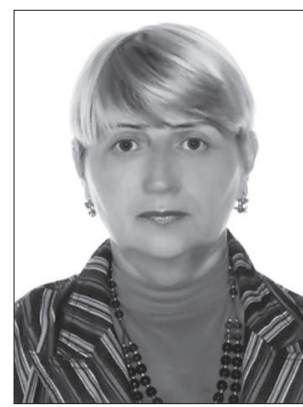

КЮЛь Елена Владимировна кандидат географических наук, заведующий Центром географических исследований Кабардино-Балкарского научного центра РАН.

Научные интересы - исследования опасных природных процессов (снежных лавин, селей, оползней, обвалов, осыпей, паводков и др.) и их влияние на геосистемы и хозяйственную деятельность.

Количество публикаций - более 150 научных работ, в том числе 2 авторских свидетельства. Опубликовано 5 монографий и 1 нормативный документ.

360002, г. Нальчик, Россия

Тел. : +7(960)430-87-36

E-mail: elenakyul@mail.ru

Elena VI. KYUL - Candidate of Geographical Sciences, Head of the Center for Geographical Studies of Kabardino-Balkarian Scientific Center of RAS.

Research interests: research of dangerous natural processes (snow avalanches, mudflows, landslides, landslides, floods, etc.) and their impact on geosystems and economic activity.

Number of publications - more than 150 scientific papers, including 2 copyright certificates. 5 monographs and 1 normative document were published.

360002, Nalchik, Russia

Ph.: +7(960)430-87-36

E-mail:elenakyul@mail.ru

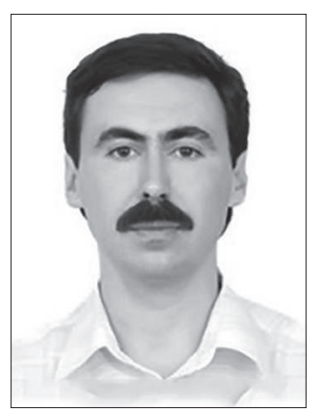

ЕЗАОВ Анзор Клишбиевич кандидат сельскохозяйственных наук, доцент, проректор по науке Кабардино-Балкарского государственного аграрного университета.

Научные интересы - исследования влияния природных и антропогенных факторов на агроландшафты.

Количество публикаций - более 70 научных работ.

360000 , г. Нальчик, Россия

Тел.: 8(8662)40-50-20

E-mail: prorector-ezaov@mail.ru

Anzor Kl. EZAOV - Candidate of Agricultural Sciences, Associate Professor, Vice-Rector for science of the Kabardino-Balkarian Agrarian University gsudarstvenny.

Research interests - research of influence of natural and anthropogenic factors on agrolandscapes.

Number of publications - more than 70 scientific papers.

360000, Nalchik, Russia

Ph.: +7(8662)40-50-20

E-mail:prorector-ezaov@mail.ru 


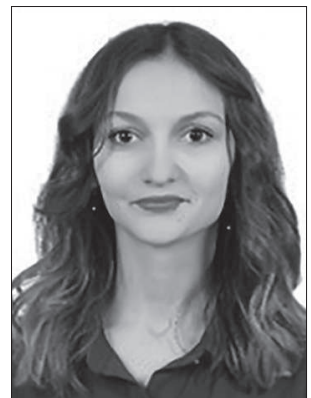

КАНКУЛОВА Лина Исмаиловна - аспирант 3-го года обучения специальности 25.0036. Науки о Земле «Геоэкология» (технические науки) Кабардино-Балкарского государственного аграрного университета.

Научные интересы - исследование влияния природных и антропогенных факторов на формирование и экологическое состояние малых водных объектов (родников и ручьёв).

Количество публикаций - более 10 научных работ.

360000, г. Нальчик, Россия.

Тел.: +7(928)712-38-08.

E-mail: lina_ismailovna@mail.ru

Lina I. KANKULOVA - postgraduate study, 3rd year, majoring 25.0036. Earth Science. "Geoecology" (technical Sciences) of KabardinoBalkarian State Agrarian University.

Research interests: research of influence of natural and anthropogenic factors on formation and ecological condition of small water bodies (springs and streams).

Number of publications - more than 10 scientific papers.

360000, Nalchik, Russia

Ph.: + 7(928)712-38-08

E-mail: lina_ismailovna@mail.ru

\section{THE THEORETICAL BASIS OF GEO-ENVIRONMENTAL MONITORING OF THE MOUNTAIN GEOSYSTEMS}

${ }^{1}$ E. V. Kyul., *

${ }^{2}$ L. I. Kankulova,

${ }^{2}$ A. K. Ezaov

${ }^{1}$ Federal State Budget Scientific Institution «Federal Scientific Center «Kabardino-Balkar Scientific Centre of the Russian Academy of Sciences», Centre for Geographical Studies, 360002, Nalchik; Kabardino-Balkar Republic, Russia, elenakyul@mail.ru

${ }^{2}$ Federal State Budgetary Educational Institution of Higher Education «Kabardino-Balkarian State Agrarian University», 360000, Nalchik, Kabardino-Balkar Republic, Russia

\section{DOI: $10.21177 / 1998-4502-2019-11-1-36-43$}

The article presents the principles of geo-ecological monitoring developed by the authors. The complex geoecological approach allows to estimate transformation of landscapes under the influence of dangerous natural processes taking into account the anthropogenic component. Cartographic method is the main method in monitoring. In addition, the study of photographs and multispectral space images is carried out in the MultiSpec Program is carried out in order to identify areas of landscapes with different degrees of transformation of the dangerous processes. As a result, the authors identify three stages of monitoring. At the same time, methods and techniques of monitoring are defined for each stage. The principles of territorial division developed for mapping and zoning of dangerous processes: the creation of the so-called hydrograph-geomorphological framework. A number of classifications have been compiled to assess the vulnerability of the territory to dangerous processes in their inventory: dangerous natural processes, conditions and factors of their formation, types of land use. The parameters for assessing the impact of dangerous processes on individual components of the landscape (terrain, vegetation, soil) are presented for passportization of monitoring objects. At the same time, it is sites of formation of dangerous processes act as objects. The criteria of distribution of the main units of formation of processes on priority and frequency of inspection, and also classes of danger of economic objects in a zone of action of these processes are given for creation of a monitoring network and ranking of sites. In the future, this approach allows to develop measures for prevention, control and protection from dangerous processes. At the same time, the area assessment of the territory's exposure to the dangerous process can be carried out on the basis of classifications of conditions and factors of formation of processes, as well as the principles of territorial division. This assessment allows the removal of part of the territory with a high degree of danger from use in its development. Moreover, a number of economic activities that lead to the activation of processes may be prohibited in the further development of the already developed territory. The results of the passportization and ranking of monitoring objects allow you to choose the optimal variant of the control measures with dangerous processes and to reduce their impact on the landscape to an acceptable minimum. The territory acquires the status of potentially safe with this geoecological approach.

Keywords: dangerous natural processes; geo-ecological monitoring, dangerous natural processes, geosystems, landscapes, inventory, passportization , ranking

\section{References:}

1. Gunya A. N. Modernization and sustainable development of mountain territories . Sustainable Development of Mountain Territories, 2016, vol. 8, no 4, pp. 281-288. DOI: 10.21177/1998-4502-2016-8-4-281-2882. (in Russian).

2. Akselevich V.I. Geo-enviromental monitoring system and its organization in the interests of ensuring the security of cities. International Journal of Applied and Fundamental Research, 2015, no. 8-1, pp. 70-74. Available at: 
http: // applied-research.ru/ru/article/view?id=7044 (accessed 06.04.2018). (in Russian).

3. Ginko V.I., Tararov A.G. The system of ecological monitoring in the management of environmental risk. Modern Problems of Science and Education, 2015, no.3, p. 328. Available at:http://science-education.ru/ ru/article/ view?id $=18878$ (accessed 06.04.2018). (in Russian).

4. Zherdev V.N., Orlov A.N. Geo-ecological monitoring: study of controlled parameters of specially protected areas. Proceedings of Voronezh State University. Series: Geography. Geo-Ecology, 2000, no. 1, pp.139-141. (in Russian)

5. Kyul E. V., Borisova N. A. Geoecological monitoring: the establishment of the monitoring network the results of the inventory and certification. Proceedings of the IV allRussian conference "Ecology. Economy. Informatics. System analysis and modelling of economic and ecological systems, Abrau-Durso, 11-17 September 2016, Abrau-Durso, 2016, pp.145-149. (in Russian)

6. Kyul E.V. A methodology for the assessment of impacts of snow avalanches in mountain landscapes. Proceedings of the III International Symposium on"Physics, Chemistry and Mechanics of Snow", part II, Yuzhno-Sakhalinsk, 2-6 October 2017, Yuzhno-Sakhalinsk, 2017, pp.62-66. (in Russian)

7. GIS-Lab: Processing of Multispectral Satellite Images. Available at: http:/gis-lab/info/qa/multispec-sat.htm. (Accessed 06.04.2018).

8. State water register. Available at: www.textual. $\mathrm{ru}>\mathrm{gvr} /$. (Accessed 06.04.2018).

9. Anisimova N.G., Viktorov A.S., Dzecker E.S., Zorina E.F., Krupderov V.S., Kutepov V.M., Larionov G.A., Litvin L.F., Ragozin A.L., Osipov V.I., Saf'janov G.A., Chalov R.S., Sheko A.I. Russia's natural hazards. Exogenous geological hazards. Moscow, Publishing House "Kruk", 2002, vol.3, 348 p. (in Russian)

10. Cenderelli D.A., Wohl E.E. Flow hydraulics and geomorphic effects of glacial-lake outburst floods in the Mount Everest region, Nepal. Earth Surface Processes and Landforms, 2003, vol.28, no.4, pp. 385-407. DOI:10.3189 $/ 172756410790595895$.

11. Donald Bedunah; Rick Graetz; Alexey Gunya; Spike Hampson; Marc S. Hendrix; Ardeshir Kia; Merhdad Kia; Alex Klaits; James W. Sears Discovering Central Asia: Its History, Geography, and Politics. Co-authors: The University of Montana Press, 2012. 382 p.
12. Gentili R., Armiraglio S., Sgorbati S., Baroni C. Geomorphological disturbance affects ecological driving forces and plant turnover along an altitudinal stress gradient on alpine slopes. Plant Ecology, 2013, vol. 214, issue 4, pp. 571586. DOI: 10.1007/s11258-013-0190-1.

13. Patten R.S., Knight D.H. Snow Avalanches and Vegetation Pattern in Cascade Canyon, Grand Teton National Park, Wyoming, U.S.A. Arctic, Antarctic and Alpine, 1994, vol.26, no.1, pp. 35-41. DOI:10.2307/1551874.

14. Sinickas A., Jamieson B. Validating the Space-Time model for infrequent snow avalanche events using field observations from the Columbia and Rocky Mountains, Canada. Arctic, Antarctic and Alpine Research, 2016, vol. 48, no 1, pp. 177-197. DOI:10.3189/172756404781814960.

15. Rixen Ch., Haag S., Kulakowski D., Bebi P. Natural avalanche disturbance shapes plant diversity and species composition in subalpine forest belt. Journal of Vegetation Science, 2007, vol. 18, pp. 735-742. 2009. DOI:10.1111/j.1654-1103.2007.tb02588.x

16. Aksenova E.G., Garanova M.V. Actual problems of land management and cadastre. Economy and Ecology of Territorial Formations, 2017, no.1, pp.93-95. (in Russian)

17. Khazhmetov L.M., Ezaov A.K., Sasikov A.S. Stationary monitoring resources reproducing processes agromeliorative. Proceedings of the International (correspondence) scientific-practical conference "Vector of development of modern science”, Sofia, 27 November 2016, Sofia, 2016, pp.42-45. (in Russian)

18. Gunya A. N. Socially-oriented concepts and approaches in the study of the Caucasus mountain areas and ensuring sustainable development. Sustainable Development of Mountain Territories, 2015, no. 3(25), pp. 281-288. (in Russian)

19. Khashirova T.Ju., Gergov A.R., Georgieva M.A., Akbasheva G.A. Application of information technologies in assessment of ecological stability of mountain and foothill landscapes. Fundamental Research, 2017, no.7, pp. 83-87. Available at: http: // fundamental-research. ru/ru/ article/ view?id=41589 (Accessed 06.04.2018). (In Russian)

20. Severskii I.V., Blagoveshchenskii V.P. Assessment of avalanche danger of mountain territory. Alma-Ata, Nauka, 1983. 219 p. (in Russian)

Article received 16.04.2018 


\section{СЕЛЕВЫЕ ПРОЦЕССЫ В АЗЕРБАЙДЖАНЕ И МЕТЕОРОЛОГИЧЕСКИЕ ФАКТОРЫ ИХ ФОРМИРОВАНИЯ (на примере Большого Кавказа)}

УДК: 502; $574 / 47.9245 /$ DOI: 10.21177/1998-4502-201911-1-44-54

Рассматриваются особенности селевых процессов, происходящих на территории Большого Кавказа. Проводится анализ метеорологических факторов, влияющих на их развитие. $B$ ходе исследования установлено, что процесс селеформирования тесно зависит от характера распространения интенсивных атмосферных осадков. С учетом влияния общей циркуляции атмосферы возможно выявить некоторые прогностические признаки выпадения осадков и селеобразование.

\section{КЛЮЧЕВЫЕ СЛОВА:}

сель, катастрофа, экзодинамические процессы, метеорологический фактор, типы циркуляции, антропогенный фактор

Статья поступила в редакцию 13.09.2018.
Введение. Активизация природных и антропогенных катастроф с начала XXI в. отмечалась во всех странах мира. Однако в горных регионах одним из главных типов катастроф, по нашему мнению, есть и остаются селевые процессы. Считаем, что до сегодняшнего дня еще не разработаны эффективные методы их предотвращения. Селевые процессы на своем пути разрушают населенные пункты, промышленные объекты, дороги, систему коммуникаций, приводят к человеческим жертвам и др. [1-4]. С 3 по 17 июня 2018 г. после нескольких проливных дождливых дней в Исмаиллинском, Агсуинском и Шамахинском районах Азербайджана прошли селевые потоки. В селении Машадганлы Агсуинского района, в селах Буйнуз и Дияллы Исмаиллинского района, в селении Мадраса Шамахинского района сели смыли мосты, дороги, соединяющие села с численностью населения более 5000 человек с райцентрами (рис. 1), унесено несколько автомашин. Разрушены опоры линий электропередачи и телефонной связи, нарушено водо- и газоснабжение села, полностью разрушены оросительные каналы. Повреждены посевные поля и фруктовые сады. Нанесен ущерб домашней птице и скоту. 24 июня 2018 г. в результате ливневых осадков в селах Тезекенд и Хошбулаг Дашкесанского района селевые потоки разрушили мосты, объекты отдыха, жилые дома. В селе Гарагуллар разрушена автомобильная дорога, унесено несколько автомашин. Повреждены электрические и коммуникационные вышки, разрушены пять трансформаторов. Подобные явления были зафиксированы и на прилегающих территориях страны (рис. 2).

Следовательно, опасность катастрофических последствий прохождения селей, а также материального ущерба остается высокой, а необходимость комплексной оценки селевой опасности остается актуальной [5-7].

Селевые процессы развиты почти во всех горных территориях Азербайджана и в зависимости от условия формирования имеют различную активность.

Селевые потоки Азербайджана распределены в следующих регионах:

1. Наиболее активной селевой деятельностью характеризуется южный склон Большого Кавказа. По характеру выносимой массы сели подразделяются на грязе-каменные (наблюдаются на участке от р. Курмухчай до р. Агсучай, отчасти p. Талачай), в геологическом строении бассейнов которых участвуют устойчивые и малоустойчивые горные породы, и водо-каменные потоки (наблюдаются на участке от р. Мазымчай до р. Мухахчай), в геологическом строении бассейнов которых участвуют малоустойчивые горные породы;

2. Северо-восточный склон Большого Кавказа и Гобустана. Здесь на характер формирования и прохождения неструктурных селевых потоков влияют орографические особенности территории. Поэтому данный регион делится на два района, где: а) селевые потоки формируются на притоках, а на основных реках сели не наблюдаются; б) неструктурные селевые потоки периодически повсеместно наблюдаются на рр. Шабранчай, Пирсаатчай, Девечичай и др.;

${ }^{1}$ Институт географии им. акад. Г.А. Алиева Национальной Академии наук Азербайджана, г. Баку, Азербайджан, kerimov17@gmail.com 
3. Нахчыванская Автономная Республика характеризуется повсеместным прохождением селевых потоков. Это связано с особенностями физико-географических условий территории: слабое развитие луговой растительности, отсутствие лесов, резко континентальный климат, интенсивные процессы физического выветривания в верховьях рек, перевыпас скота в высокогорных районах и др. По степени селевой активности и мощности потоков территория подразделяется на: а) район с наиболее активным проявлением селевых процессов - восточнее p. Гиланчай (pp. Ванандчай, Айлисчай, Ордубадчай, Ганзачай, Кетамчай). Здесь растительный покров отсутствует, слабо развит почвенный покров, большая крутизна и скалистость склонов и др. Селевые очаги, состоящие в основном из обломочных горных пород, располагаются на высоте более 2500 м.; б) район относительно слабого проявления селевых процессов - западнее р. Гиланчай (рр. Арпачай, Чанахчычай, Алинджачай, Нахчыванчай). Здесь альпийская и субальпийская растительность несколько богаче, леса встречаются небольшими пятнами (бассейна рр. Нахчыванчай и Алинджачай), крутизна склонов относительно пологая и др. Селевые очаги располагаются на высотах ниже 2500 м. По характеру выносимой массы сели Нахчывана подразделяются на грязе-каменные (западнее р. Гиланчай - реки, стекающие со склонов Даралагезского хребта) и водо-каменные (восточнее р. Гиланчай - реки, стекающие с юго-западного склона Зангезурского хребта);

4. Северо-восточный склон Малого Кавказа. Здесь селевая деятельность почти не выражена, т.к. характерной особенностью данной территории является менее широкое развитие высокогорного рельефа (г. Гямышдаг - 3724 м), склоны менее крутые, более

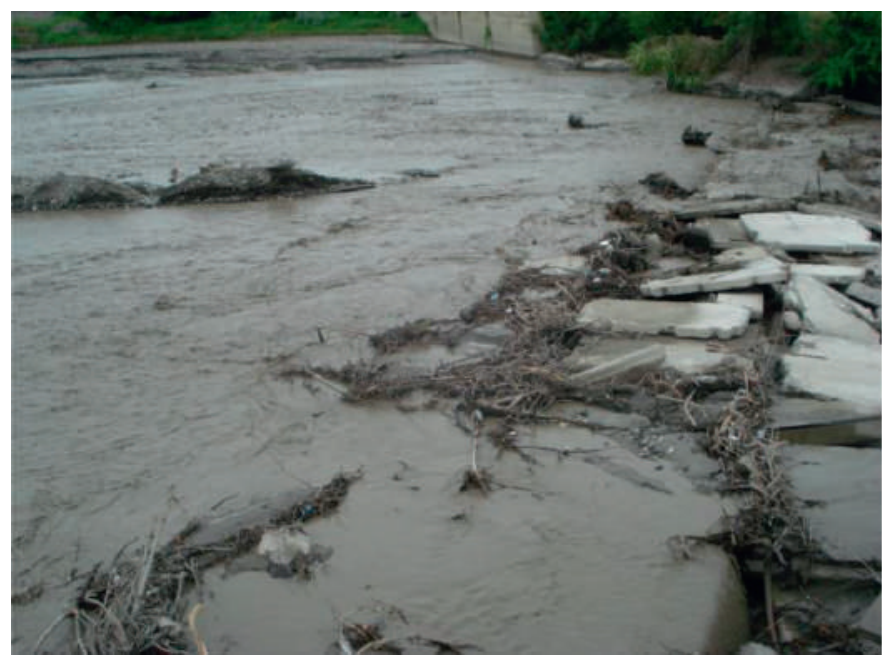

Pис. 1. Разрушенные селезашитные сооружения р. Агсучай в с. Мадраса Шамахинского района

Fig. 1. Destroyed mud dams on the river Agsuchay in the village of Madrasa, Shamakhi region задернованные и залесенные. Однако мощные конусы выноса рр. Агстафачай, Зейамчай, Шамкирчай, Гянджачай, Тертерчай, Хачинчай, Гаргарчай свидетельствуют о прохождении в прошлом структурных селей. Селевые потоки (преимущественно водо-каменные) наблюдаются в бассейнах pp. Ахынджачай, Тоузчай, Джагирчай и частично Гаргарчай, а также в верховьях от р. Агстафачай до р. Гянджачай;

5. Ленкорань. Здесь, несмотря на обильное выпадение атмосферных осадков (более 1600 мм), селевые явления наблюдаются редко. Это связано с небольшой крутизной, задернованностью и залесенностью склонов. Однако, в результате прохождения отдельных ливней, южнее р. Ленкоранчай происходят неструктурные селевые потоки (рр. Ленкоранчай, Тангерудчай, Астарачай).

В настоящее время нет однозначного ответа на вопрос о механизмах зарождения селей. Баринов А.Ю. [8] считает, что даже при наличии нужных для формирования селей условий, их возникновение невозможно без какого-либо дополнительного импульса, например, ливня, обильного снеготаяния и др., или же их совокупности. Существуют территории, где есть все предпосылки для возникновения селя, однако они годами могут оставаться в неизмененном состоянии, другие же, напротив, внезапно становятся зоной развития катастрофического селя. Однако «внезапно» не значит «не закономерно» [8].

Объекты и методы исследования. Орографические и структурные особенности районов Азербайджана определяются наличием крупных горных массивов - Большого и Малого Кавказа и расположенной между ними Куринской межгорной впадиной. Территория Большого Кавказа является одним из наиболее селеопасных регионов не только Азербайд-

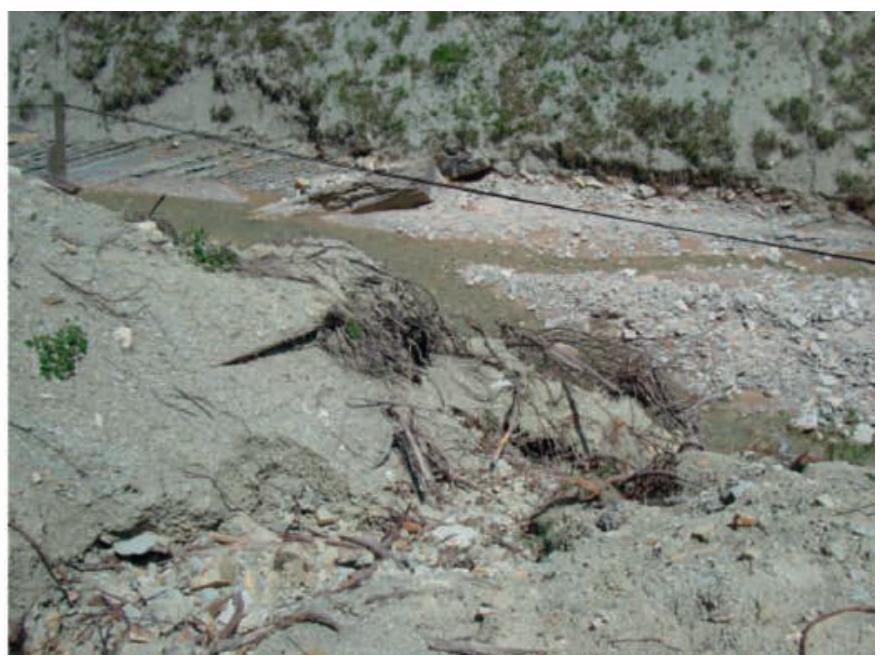

Pис. 2. Последствия селя на р. Шамкирчай в с. Гарагуллар Дашкесанского района

Fig. 2. Consequences of a mudflow on the Shamkirchay River in the village of Garagullar, Dashkesan District 
жана, но и на Кавказе. Геолого-геоморфологические особенности условия в его пределах способствуют интенсивному развитию таких опасных природноразрушительных процессов, как лавинные, обвальные, селевые, оползневые и др.

Небольшие сели в бассейнах рек Большого Кавказа проходят неоднократно и ежегодно. Но были годы, когда наблюдались катастрофические сели, приведшие к разрушениям и человеческим жертвам. Например, в 1910 г. сель на р. Шинчай полностью разрушил село Баш-Гейнюк Шекинского района со всем населением (сейчас там проживает 1658 человек). Выявление наиболее информативных факторов, влияющих на формирование селевых процессов, представляет собой большой научный и практический интерес, т.к. они могут быть использованы в прогнозировании таких явлений [9].

Вначале дадим краткую характеристику геоморфологического строения Большого Кавказа. Современная эндогенно обусловленная геодинамическая модель Большого Кавказа, обусловленная сложными и длительными складчато-блоково-шарьяжными подвижками привела к формированию сложных по генезису и по возрасту региональных, субмеридиональных, субширотных морфоструктур, представленных структурно обусловленными формами рельефа. Именно эти обусловленности и разнообразный по денудационной устойчивости комплекс горных пород, слагающие морфоструктуры и выделенные на поверхности в различных диапазонах абсолютных высот, а также последующие изменения физико-географических условий, определили основные закономерности проявления и протекания экзодинамических процессов, которые в конечном счете привели к формированию современного, интенсивно расчлененного, сильно дифференцированного рельефа.

В пределах Большого Кавказа по морфотектоническим и морфоструктурным особенностям, посредством которых определяется характер, направленность и интенсивность экзодинамических процессов, четко выделяются три морфотектонические зоны [10]:

1. Узкая, опрокинутая песчано-сланцевая, грабенсинклинорная зона чешуйчато-надвиговых морфоструктур южного склона Большого Кавказа;

2. Блоковая, известняково-песчаная, наложенная горст-синклинорная зона шарьяжно-надвиговых морфоструктур Бокового хребта;

3. Сильно расчлененная, веерообразно расширяющаяся и подвергающаяся погружению зона шарьяжно-надвиговых морфоструктур юго-восточной оконечности Большого Кавказа. Опрокинутые на юг песчаносланцевые комплексы пород, слагающие высоко приподнятые над уровнем моря (3000-3500 м) новейшими тектоническими движениями морфоструктуры Туфанской зоны (от р. Мазымчай на западе до рр. Гейчай-Вандамчай на востоке) определили своеобразие проявле- ния экзодинамических процессов, их направленность и интенсивность. Тучанская и Загатало-Говдагская крупные складчато-глыбовые морфоструктуры, имея круто обрывающиеся на юг по ограничивающим их разломам склоны, обусловили интенсивное развитие процессов и привели к формированию сильно расчлененного современного рельефа Большого Кавказа. Здесь преобладающими являются гравитационные и водно-эрозионные геодинамические процессы, которые образуют скальные обнажения, обвалы, оползни, крутые уступы, осыпи, россыпи, рытвины, речные долины и другие линейные эрозионные элементы рельефа. Совокупность благоприятных морфотектонических, геоморфологических, климатических, литологических и других условий для протекания гравитационно-флювиальных процессов на оголенных, крутых, сильно эродированных склонах, переработанных доледниковой, ледниковой и послеледниковой денудацией, создали идеальные предпосылки для доминирования здесь таких процессов, как селевые, которые часто повторяются и приводят к катастрофическим последствиям [11].

Выявлено, что сели чаще всего образуются на южном склоне Большого Кавказа. Этот район характеризуется максимальным количеством ливней на территории республики. Здесь 91,2 \% селей наблюдались в мае-августе, а максимальное количество селей приходилось на долю июля. За исследуемый период самыми селеактивными являлись рр. Кишчай, Шинчай, Курмухчай, Гирдиманчай и др. Если обратимся к повторяемости селей на северо-восточном склоне Большого Кавказа, то нетрудно увидеть, что здесь сели несколько раз меньше количества селей, отмеченных на южном склоне. Здесь 87,1 \% селей наблюдаются в апреле-июле, а максимум приходится на июль. В августе селей совсем мало, а осенью наблюдается их незначительное увеличение. В обоих селеопасных районах Большого Кавказа существуют благоприятные геолого-геоморфологические и почвенно-растительные условия. Однако на северо-восточном склоне обильные ливневые осадки повторяются меньше, чем на южном склоне. Увеличение повторяемости таких селеобразующих осадков на южном склоне Большого Кавказа зависит, помимо других факторов, от экспозиции местности по отношению к господствующему направлению переноса холодных и влажных масс воздуха, большой неустойчивостью и высокой удельной влажностью, а также от характера атмосферных процессов, высоты местности, формы рельефа и др. Этот район подвергается воздействию юго-западных и, отчасти, западных влажных неустойчивых масс воздуха, которые в зоне холодного фронта, при встрече с горными хребтами, вынужденно поднимаются и, как обычно, при общей конвективной неустойчивости приводят к образованию мощных конвективных облаков, из которых выпадают ливневые осадки. Таким образом, ливни, а также связанные с ними селевые по- 
токи, обычно формируются на наветренных склонах горных хребтов. При юго-западных процессах северовосточный склон Большого Кавказа оказывается подветренным, поэтому повторяемость ливней меньше, чем на южном склоне. На южном склоне Большого Кавказа более интенсивные ливни наблюдаются в западной его части. Здесь суточные максимумы осадков составляют 80-100 мм, иногда до 200 мм. Ливни с суточным количеством 50-60 мм могут выпадать ежегодно, 80-100 мм - раз в 10 лет, более 100 мм - раз в 20 лет. Из анализа данных о селеобразующих осадках установлено, что сели на территории республики формируются при выпадении осадков в количестве 20 мм и более за сутки [12]. Экстремальные значения селеобразующих дождей на южном склоне Большого Кавказа составляют 20-188 мм, а в районе северо-восточного склона Большого Кавказа с Гобустаном - 20 132 мм. Максимальное количество селепрохождения в основных селеопасных районах наблюдается в период наибольшей повторяемости обильных осадков. Число дней с суточным количеством осадков $\geq 20$ мм на южном склоне Большого Кавказа увеличивается примерно до высоты 2200-2400 м, на северо-восточном склоне - до 3000-3200 м. Согласно анализу, доля ливневой части (продолжительность и сумма осадков) в обильных осадках $\geq 20$ мм в разных селеопасных районах разнообразны, так как они на южном склоне Большого Кавказа составляют соответственно 20,1 и 58,2 \%, а на северо-восточном склоне Большого Кавказа с Гобустаном - 15,2 и 50 \%. Таким образом, выявлено, что сели возникают при продолжительных, длящихся в течение нескольких часов дождях, сопровождаемых короткими ливнями, интенсивностью 0,45-2,00 мм/ мин и более (таблица).

В Азербайджане в большинстве случаев изучались физико-географические, геоморфологические, гидрологические и лишь в последние десятилетия метеорологические условия селеобразования. Эти факторы, как известно, благоприятствуют формированию селевых потоков, однако в исследуемом регионе основная роль принадлежит интенсивным ливневым осадкам. Поэтому, прежде всего, необходимо исследовать метеорологические условия, вызывающие ливневые осадки, которые приводят к образованию селей.

Из анализа данных синоптических процессов, приводящих к формированию селей, установлено, что 3/4 случаев сели образовались при юго-западных, а 1/4 при западных процессах, т.е. сели возникли, когда над территорией Южного Кавказа в тропосфере преобладали юго-западные и западные воздушные течения. Очень редко они образовались при северо-восточных и южных течениях. Изучая циркуляционные процессы, приводящие к селям ливневого происхождения, установлено, что они определяются вторжением холодных масс воздуха на территорию Южного Кавказа. Для этих вторжений характерна резко выраженная меридиональность воздушных течений в тропосфере, глубокое проникновение ложбины холода из более северных и северо-западных районов Европейской территории России, большие контрасты температур в высотной фронтальной зоне (ВФЗ) над данной территорией (8-10\%/1000 км). Следует отметить, что при меридиональном преобразовании высотных деформационных полей (ВДП) над Европой в тылу высотной ложбины холодные массы воздуха из северной Европы проникают на юг. До вторжения на юг эти массы воздуха имеют устойчивую стратификацию. Однако по мере движения на юг они начинают прогреваться снизу, а в средней и верхней тропосфере остаются холодными, в результате чего приобретают неустойчивость. Когда с адвекцией холода усиливается высотная ложбина и достигает Средиземного моря, проникающие холодные массы характеризуются довольно большой неустойчивостью. В дальнейшем, по мере развития крупномасштабных процессов высотная ложбина смешается к востоку - на территорию Малой Азии и Южного Кавказа. В результате на территорию Азербайджана проникают неустойчиво-стратифицированные холодные и влажные воздушные массы.

Поскольку количественные характеристики энергии неустойчивости имеют большое значение для определения вероятности выпадения ливневых осадков и селеопасного периода, мы сочли целесообразным рассчитать ее параметры, особенно запас положительной энергии неустойчивости, который был определен как сумма разности температур поднимающейся частицы и окружающего воздуха на разных поверхностях тропосферы до уровня конвекции. Для выпадения особо интенсивных ливней неустойчивая стратификация должна охватить всю тропосферу. Выявлено, что почти во всех случаях за период селеобразования наблюдался достаточный запас положительной энергии неустойчивости, и уровень конвекции нередко достигал поверхности 300-200 гПа.

Кроме наличия положительной энергии неустойчивости для выпадения обильных и интенсивных ливней необходимо и высокое значение удельной влажности. Исследование показало, что она в действительности в период селеобразования имела очень большую величину не только у поверхности Земли, но и на разных высотах в тропосфере. Согласно анализу, в дни селеобразования значение удельной влажности повышается по сравнению с предыдущими днями.

Для анализа крупномасштабных процессов, приводящих к ливневым осадкам, а при их высокой интенсивности, и к селям, на исследуемой территории были определены количественные и качественные показатели макроциркуляции. Для количественного определения типов циркуляции были использованы критерии общего индекса, предложенные Кацем А.Л. [13]. Исследование показало, что в дни селеобразований в основном преобладали меридиональные, а в некоторых 


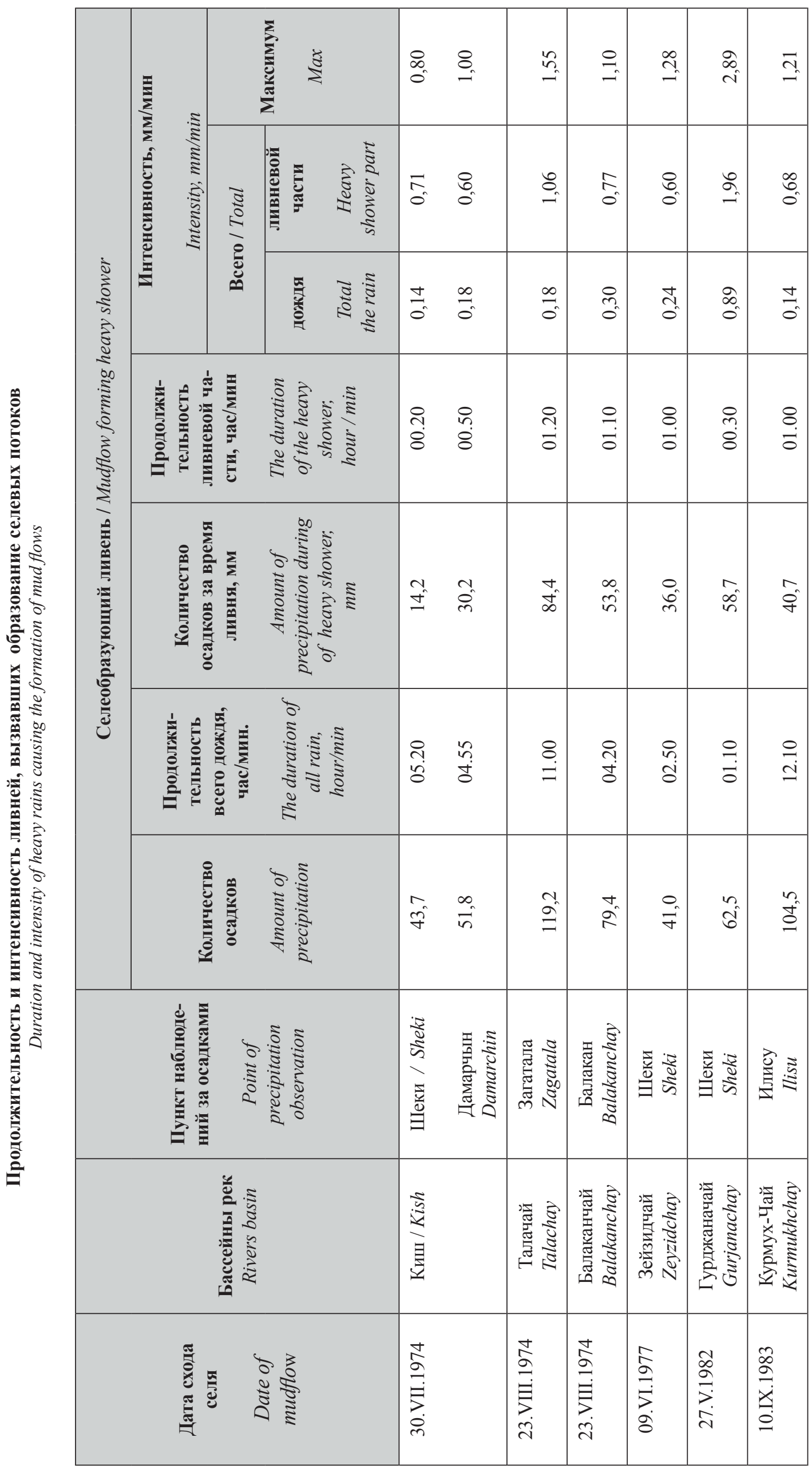


случаях - зональные процессы. Следует отметить, что, как правило, зональные процессы на территории Южного Кавказа, в том числе Азербайджана к обильным ливневым осадкам и селям не приводят. Для выпадения интенсивных ливней и формирования селей необходимо вторжение холодных, влажных и неустойчивостратифицированных воздушных масс, что происходит только при меридионально развивающихся процессах. Исследование селей при зональных процессах показало, что за несколько суток до начала селей над Западной Европой произошло меридиональное преобразование циркуляции, в результате которых холодные массы воздуха в тыловой части высотной ложбины через район Британских островов вторгаются в южные районы Западной Европы, где происходит усиление ВФЗ и циклогенез. В дальнейшем высотная ложбина и циклон постепенно смещается к востоку - на территорию Малой Азии и Южного Кавказа. Иначе говоря, при образовании селей взаимодействовали те массы холодного воздуха, которые вошли в систему ВФЗ в период меридионального преобразования.

При меридиональных преобразованиях под высотным гребнем в нижней тропосфере на севере Европы образуются антициклоны. В дни селеобразования они смещаются на центральные районы Европейской части России. Стационирование этих антициклонов происходит при блокировании циклона над Малой Азией - востоком Средиземного моря. Следует отметить, что разделение атмосферных процессов количественным способом на зональные и меридиональные дает общее представление о направлениях воздушных течений в тот или иной период времени, но этого не всегда достаточно для детальной характеристики процессов, приводящих к обильным ливням и селям. Поэтому мы сочли целесообразным использование и качественных методов определения характера цирку- ляции. Чтобы выявить связь между атмосферной циркуляцией и селями в Азербайджане были использованы типы циркуляции по классификации Вангенгейма Г.Я. [14] и Дзердзеевского Б.Л. [15]. Вангенгейм Г.Я. [14] принял более простую форму типизации атмосферных процессов. Он предложил 3 типа или формы основных атмосферных процессов: западный $(W)$, меридиональный $(C)$ и восточный $(E)$. При типе $W$ преобладает западный перенос масс воздуха, при $C$ перенос происходит с северо-запада и севера, а при $E$ - с северо-востока. Исследованием установлено, что между селями в Азербайджане и процессами $E$ существует прямая связь, т.е. при усилении этих процессов на исследуемой территории происходит активизация селей. Наоборот, при процессах $W$ селеобразование ослабляется. Полученные результаты оправдывают себя не только на Кавказе, а также в регионах Средней Азии [16], так как на реках этих территорий активизация селевых явлений наблюдается при процессах $E$, а ослабление - при процессах $W$. При макроформах $E$ в Средней Азии, Казахстане, а также на Кавказе осадки выпадают выше нормы, что приводит к повышению вероятности образования селей. При процессах $W$ на указанных территориях осадки выпадают мало и селевая деятельность ослабляется [17; 18$]$.

При западном переносе не безразлично на какой широте располагается ось высокого давления. Поэтому процессы $W$ можно подразделить на два подтипа $\left(W_{1}\right.$ и $\left.W_{2}\right)$. Такое деление показывает, что погодные условия на территории Южного Кавказа, как и вдоль его широт различны. В первом случае $\left(W_{1}\right)$ область высокого давления охватывает южные районы Европы и, следовательно, при этом подтипе здесь, как и в Южной Европе преобладает засушливая погода. При подтипе $W_{2}$, наоборот, область антициклона располагается на широтах севернее $50^{\circ}$ с.ш., а над южными районами

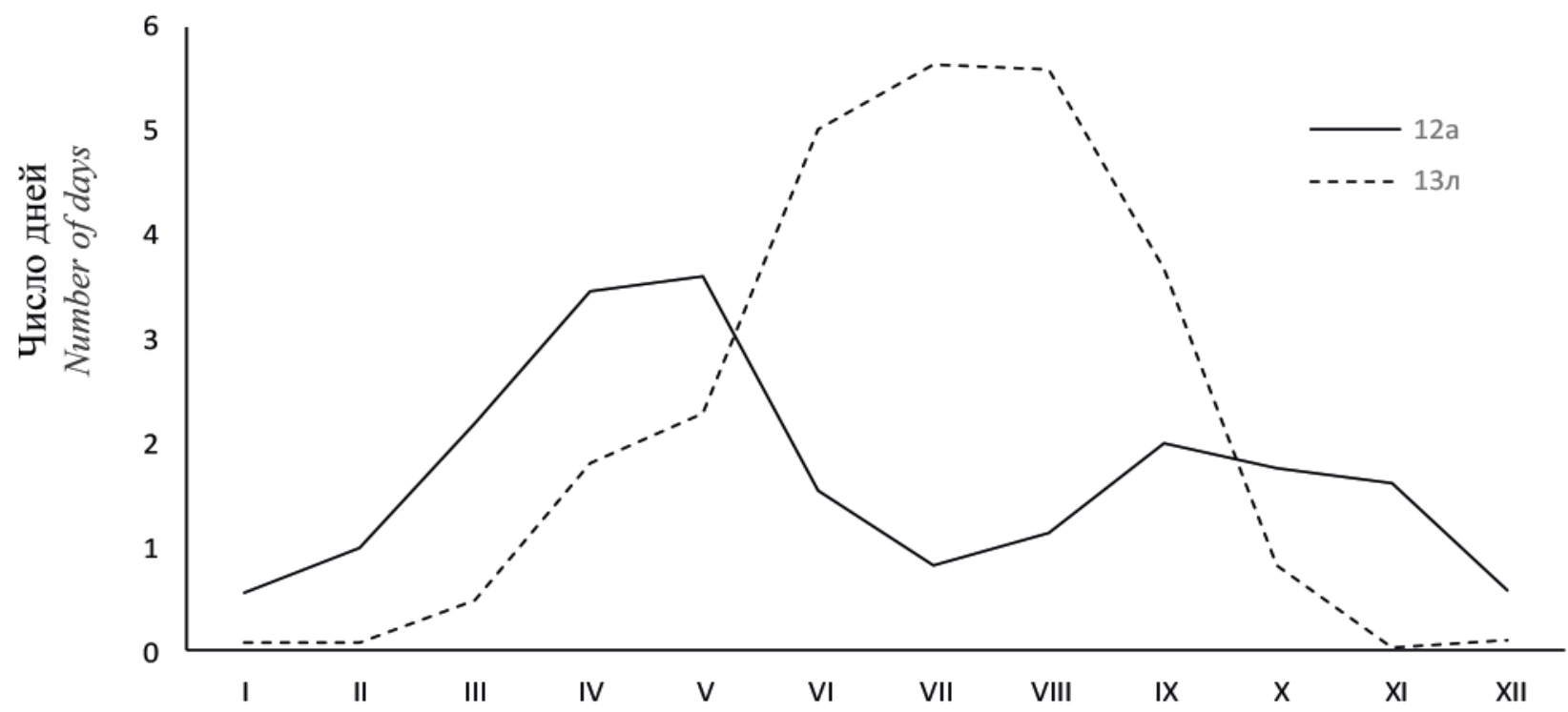

Рис. 3. Повторяемость типов ичиркуляциии

Fig. 3. Repeatability of circulation types 
Европы, в том числе и на Южном Кавказе преобладает циклоническая погода с достаточным увлажнением.

Для оценки синоптических ситуаций, приводящих к образованию селей, была использована также классификация типов атмосферной циркуляции по Дзердзеевскому Б.Л. [15]. Установлено, что сели в Азербайджане в основном формируются при подтипе $12 \mathrm{a}$ (подтип северной меридиональной циркуляции) и 13л (подтип южной меридиональной циркуляции, господствующий летом). Эти подтипы наблюдались во всех селеопасных месяцах за период 1960-2014 гг., и привели к выпадению селеобразующих осадков. В некоторые годы одни типы по сравнению с другими были более интенсивными и отличались ростом повторяемости. Например, в период уменьшения повторяемости подтипа 12а (1980-1992 гг.) наблюдалось увеличение подтипа 13л, а в 2008-2014 гг. наоборот. За период 1899-2014 гг. участие макропроцессов подтипа 12а всегда были заметными в селеобразовании. Однако процессы подтипа 13л активизировались, начиная с 60-х годов XX века, и из года в год росла их повторяемость (рис. 3).

При подтипе 13л происходит выход южных циклонов на территорию Северного и Южного Кавказа. Они отличаются большой скоростью перемещения и значительными температурными контрастами, и поэтому в кратчайшее время приводят к выпадению ливневых осадков и активизации селей. В подтипе 12 а над Сибирью формируется блокированный антициклон, вытянутый до южных областей Западной Сибири. В это время циклоны, образованные над Средиземным морем, перемещаются на территорию Южного Кавказа, а оттуда к северо-востоку. При встрече теплых и влажных масс воздуха со стороны Средиземного моря с холодными

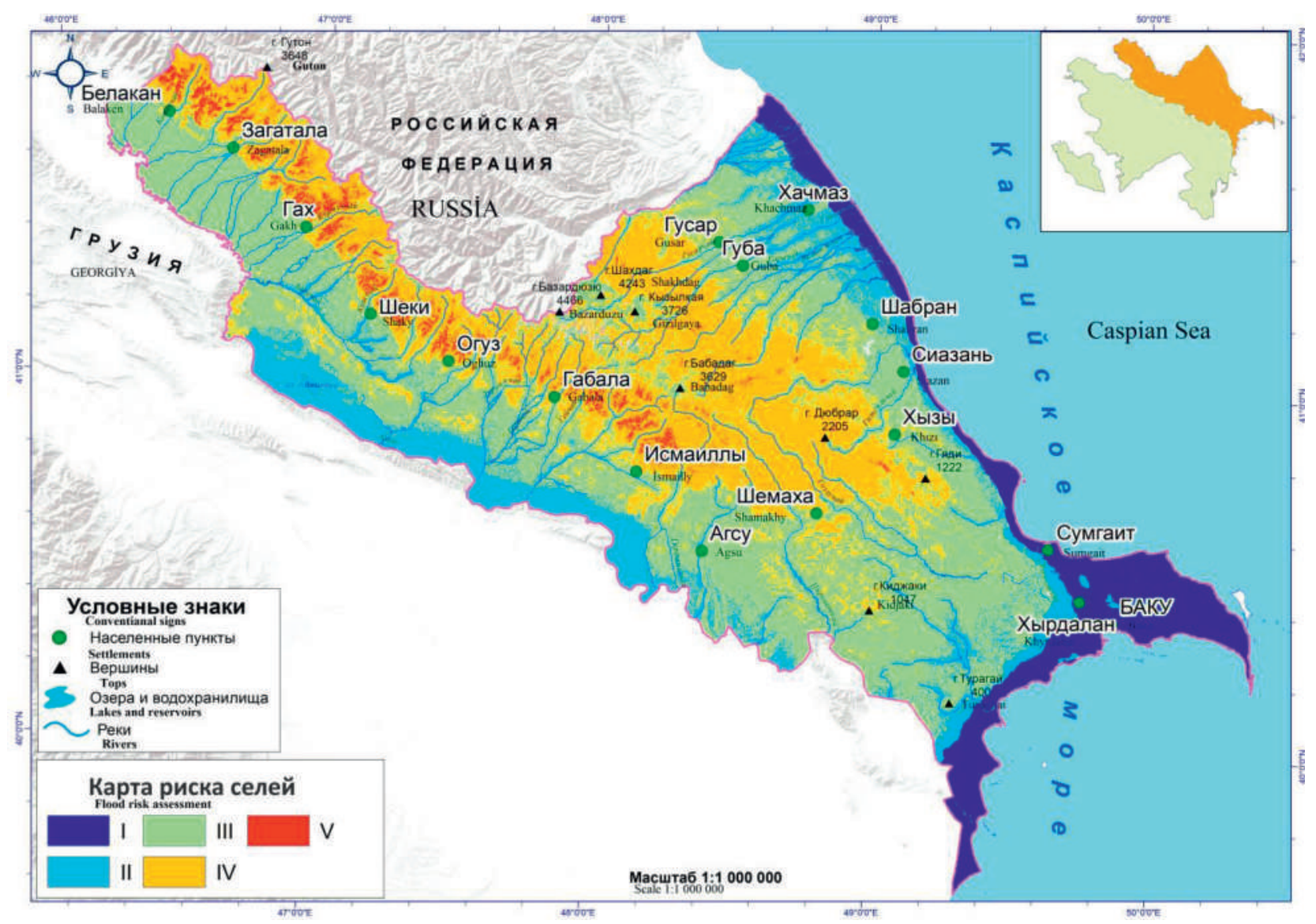

Pис. 4. Карта-схема селевой опасности азербайджсанской части Большого Кавказа (составлена Тарихазер С.А., 2018 г.):

1. Территории, где не наблюдаются селевые процессы - I балл;

2. Территории с потенциальной селевой опасностью - II балла;

3. Территории со слабой селевой опасностью (раз в 5-10 лет возможен 1 сильный сель) - III балла;

4. Территории со средней селевой опасностью (раз в 3-5 лет возможен 1 сильный сель) - IV балла;

5. Территории с высокой селевой опасностью (раз в 2-3 года возможен 1 сильный сель) - V баллов

Fig. 4. The scheme-map of the mudflow danger of the Azerbaijani part of the Greater Caucasus (compiled by Tarikhazer S.A, 2018):

1. Territories where mudflows are not observed - I point;

2. Territories with potential mud flow danger - II point;

3. Territories with low mudflow danger (1 strong mudflow is possible every 5-10 years) - III point;

4. Territories with average mudflow danger (once in 3-5 years 1 strong mudflow is possible) - IV point;

5. Territories with high mudflow danger (once in 2-3 years 1 strong mudflow is possible) - V point 
арктическими воздушными массами происходит усиление атмосферных фронтов, в результате которого на исследуемой территории осадки выпадают выше нормы, и повышается селеактивность рек [19; 20].

На основе дешифрирования аэрокосмических снимков (АКС) в пределах азербайджанской части Большого Кавказа по степени опасности селевых процессов (количестве выносимого материала, эрозионном воздействии потока на долину, учете селепроявления притоков и бассейна в целом, а также по преобладающим типам и классам селей, геоморфологическими условиями образования, формирования и прохождения селевых потоков, и на статистических данных о прошедших селях), на фактическом и возможном ущербе населения от селей была составлена карта-схема (рис. 4).

Как следует из картосхемы, к территориям с высокой селевой опасностью относятся бассейны рек Мазымчай, Белоканчай, Катехчай, Талачай, Мухахчай, Кашкачай, Кюнгютчай, Дашагылчай, Фильфиличай, Вандамчай, Гейчай (с прохождением водо-каменных селей); бассейны рек Курмухчай, Шинчай, Тиканлычай, Бумчай, Демирапаранчай, верховья рек Гирдыманчай, Пирсаатчай, Сумгаитчай, Тугчай, Гильгильчай, Вельвеличай, Атачай (с прохождением грязе-каменных селей); бассейны рек Девечичай, Шабранчай (с прохождением грязевых селей). К территориям со средней селевой опасностью относятся бассейны рек Гарачай, Гудиалчай, Гусарчай, Агчай, Чагаджугчай и другие. К территориям со слабой селевой опасностью относятся сухие долины и балки аридной зоны - Аджиноурские предгорья, Гобустан, юго-восточная оконечность северо-восточного Азербайджана, восточная оконечность Гусарской наклонной равнины. Здесь сели проходят по оврагам и балкам, имея грязе-каменный характер. Внутригорные котловины, долины и равнины нами отнесены к области затухания селевых потоков и отложения их выносов, а Абшеронский полуостров, прибрежные зоны Каспийского моря являются территориями, где отсутствуют селевые процессы.

Выявлено, что на территории исследуемого района сели формируются при выпадении интенсивных обильных осадков с большой интенсивностью, которые без вторжения холодных и трансформированных воздушных масс из северных районов Европы не образуются. При всех процессах циркуляции такие воздушные массы проникают на территорию Большого Кавказа за холодными фронтами при меридиональных преобразованиях высотных деформационных полей тропосферы. При этом усиливается высотная фронтальная зона, увеличивается значение удельной и относительной влажности воздуха, а также неустойчивость стратификации, которые приводят к выпадению селеобразующих ливней. Установлено, что в процессах Е в данном селеопасном районе се- леактивность повышается, а при W - ослабляется. В процессе селеобразования активно участвовали подтипы циркуляции 12а и 13л по классификации Дзердзеевского Б.Л. [15].

\section{Заключение}

Из вышеизложенного следует, что селевые процессы являются одним из наиболее значимых рискфакторов, фиксируемых в пределах азербайджанской части Большого Кавказа. Они усиливают экологическую напряженность и наносят огромный ущерб хозяйству страны и населенным пунктам.

Важное значение имеет детальное исследование динамики развития селевых очагов, особенностей накопления селевых материалов и их готовности к сносу, изучение характера изменения русел рек, состояния берегов и защитных сооружений (в настоящее время одной из основных мер является постройка селезащитных дамб), потенциальных путей движения селей и, на этой основе, проведение эколого-геоморфологических мероприятий с целью стабилизации экологической обстановки.

Своевременная информация об угрозе развития таких опасных явлений, как сели, позволит значительно снизить риск и размер ущерба от этих процессов.

\section{Выводы}

Установлено, что сочетание благоприятных морфотектонических, геоморфологических, климатических, литологических и других условий для прохождения гравитационно-флювиальных процессов создало предпосылки для доминирования таких процессов, как селевые потоки, которые часто повторяются и приводят к катастрофическим последствиям. Установлено, что сели на территории республики формируются при выпадении осадков в количестве 20 мм и более за сутки. Экстремальные значения селеобразующих дождей на южном склоне Большого Кавказа составляют 20-188 мм, а в районе северо-восточного склона Большого Кавказа с Гобустаном - 20-132 мм.

Для оценки синоптических ситуаций, приводящих к образованию селей, проведена классификация типов циркуляции атмосферы по Дзердзеевскому Б.Л. Установлено, что селевые потоки в Азербайджане в основном формируются подтипом 12a (подтип северного меридионального круговорота) и 131 (подтип южного меридионального круговорота, преобладающий летом).

В результате на основе интерпретации аэрокосмических снимков (ASI) была составлена карта-схема опасности селей по 5-балльной шкале в пределах азербайджанской части Большого Кавказа. 
$\overline{\text { КРИТЕРИИ АВТОРСТВА / Contribution: }}$

Тарихазер С. А. - провела анализ геоморфологического строения Большого Кавказа, составила соответствующую карту, выделила территории по селеопасности / Tarikhazer S. A. conducted an analysis of the geomorphological structure of the Greater Caucasus, made the appropriate map, identified the territory by mudflow.

КОНФЛИКТ ИНТЕРЕСОВ / Conflict of interest:

Автор заявляет об отсутствии конфликта интересов / The authors declare no conflict of interest.

\section{$\overline{Л И Т Е Р А Т У Р А: ~}$}

1. Arclnfo Help. Glossary. Environmental Systems Research Institute (ESRI), Inc.February. 2001, 15 p.

2. Abu-Zeid N. Furlanis S. Oddone E. Debris-flow hazard assessment applying the resistivity imaging method: case study of Cancia Debris-Row Hazards Mitigation: Mechanics, Prediction, and Assessment, Rickenmann \& Chen (eds) (C) Millpress, Rotterdam. 2003, 12 p.

3. Huang C-J, Yin H.-Y. Experimental study of the underground sound generated by debris flows. Debris-Row Hazards Mitigation: Mechanics, Prediction, and Assessment, Rickenmann \& Chen (eds) (C) Millpress, Rotterdam. 2003, 16 p.

4. Inaba $\mathrm{H}$. Notes on the modeling of debris-flow surface images Debris-Row Hazards Mitigation: Mechanics, Prediction, and Assessment, Rickenmann \& Chen (eds) (C) Millpress, Rotterdam. 2003, $15 \mathrm{p}$.

5. Mills K, Paul. J. Forest practices and mitigation of debrisflow risk in Oregon, USA. Debris-Row Hazards Mitigation: Mechanics, Prediction, and Assessment, Rickenmann \& Chen (eds) (C) Millpress, Rotterdam. 2003, 5 p.

6. Petrascheck A. Kienholz H. Hazard assessment and mapping of mountain risks in Switzerland. Debris-Row Hazards Mitigation: Mechanics, Prediction, and Assessment, Rickenmann \& Chen (eds) (C) Millpress, Rotterdam. 2003, 17 p.

7. Хаджиев М.М. Оценка селевой опасности района г. Тырныауза: Автореф. дисс. ... канд. геогр. наук. Нальчик, 2005. $16 \mathrm{c}$.

8. Баринов А.Ю. Геоморфологический анализ ливневой селеопасности Щели Широкая Балка (черноморское побережье Кавказа) // Геоморфология. 2010. N2. С. 19-25

9. Будагов Б.А., Сафаров С.Г. Селевые явления на южном склоне Большого Кавказа и гидрометеорологические факторы их формирования // Известия РАН. Серия географическая. 2008. N2. С. 116-121.

10. Ализаде Э.К., Тарихазер С.А. Экзоморфодинамика рельефа гор и ее оценка (на примере северо-вос- точного склона Большого Кавказа). Баку: Victoriya, 2010. $236 \mathrm{c}$.

11. Ализаде Э.К., Тарихазер С.А. Экогеоморфологическая опасность и риск на Большом Кавказе (в пределах Азербайджана). Москва: МАКСПресс, 2015. 207 с.

12. Набиев Г.Л. Сели в Азербайджанской ССР и условия их формирования // Известия АН Азерб. ССР. Серия наук о Земле. 1985. N6. С. 76-81.

13. Кац А.Л. Сезонные изменения общей циркуляции атмосферы и долгосрочные прогнозы. Л.: Гидрометеоиздат. $1973.270 \mathrm{c}$.

14. Вангенгейм Г.Я. Опыт применения синоптических методов к изучению и характеристики климата. М.: Гидрометеоиздат. 1935.109 с.

15 Дзердзеевский Б.Л. Общая циркуляция и климат. Избранные труды. Москва. 1975. 288 с.

16. Шеко А.И. Закономерность формирования и прогноз селей. Москва: "Недра". 1980. С. 296

17. Тарихазер С. А., Набиев Г. Л. Оценка проявлений селеопасности в Азербайджане (на примере Большого Кавказа) // Материалы IX Межд. научно-прак. конф. «Горные территории: приоритетные направления развития», Владикавказ, 2017. Т. 9, N3(33). С. 257-268

18. Tarikhazer S. A. Mudflow processes in mountain geosystems of coastal zones of the Caspian sea (on the example of the north-eastern slope of the Greater Caucasus). ECOSF. Understanding the problems of inland waters: case study for the Caspian basin. 12-14 may 2018. Baku, 2018, pp. 187-191.

19. Мадатзаде А.А. Синоптические условия выпадения обильных осадков, обусловливающих паводки в Азербайджане. В кн.: Материалы V Всесоюзного совещания по изучению селевых потоков и меры борьбы с ними. Баку, 1962. С. 153-156.

20. Папинашвили К.И. Обильные осадки в Восточной Грузии и аэросиноптические условия их возникновения // Труды НИГМИ. 1962. Вып. 10. С. 101-112.

\section{СВЕДЕНИЯ ОБ АВТОРАХ / Information about authors:}

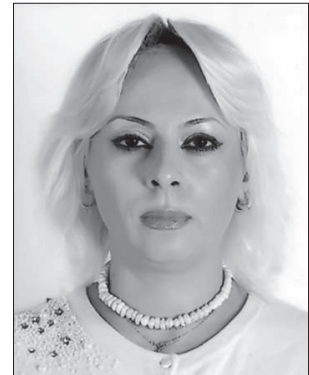

AZ1143, Azerbaijan, Baku

ТАРИХАЗЕР Стара Абульфаз-гызы - кандидат географических наук, доцент; ведущий научный сотрудник отдела «Геоморфология» Института географии им. акад. Алиева Г.А. Национальной Академии наук Азербайджана, AZ1143, ул. Г. Джавида, 115, Баку, Азербайджан.

Тел.: +994503868667.

e-mail: kerimov17@gmail.com

Stara A. TARIKHAZER - Candidate of Geographical Sciences, Associate Professor; Leading Researcher of the Department of eomorphology.

G.A. Aliyev Institute of Geography, Azerbaijan National Academy of Sciences, Baku, Azerbaijan.

Ph.: +99450 38686 67, e-mail: kerimov17@gmail.com 


\title{
MUDFLOW PROCESSES IN AZERBAIJAN AND METEOROLOGICAL FACTORS OF THEIR FORMATION \\ (On the example of the Greater Caucasus)
}

\author{
S. A. Tarihazer \\ G.A. Aliyev Institute of Geography, Azerbaijan National Academy of Sciences, Baku, Azerbaijan, kerimov17@gmail.com
}

\author{
DOI: $10.21177 / 1998-4502-2019-11-1-44-54$
}

Features of the torrential processes happening on the territory of Greater Caucasus are investigated. A brief description of the geomorphologic structure of the Greater Caucasus is given. It was established that the combination of favorable morph-tectonic, geo-morphological, climatic, litho-logical and other conditions for the passing of gravitational-fluvial processes created the prerequisites for the dominance of processes such as mudflows, which are often repeated and lead to catastrophic consequences.

From the analysis of the data on the mudflow-forming precipitation, it is established that the mudflows on the territory of the republic are formed with precipitation in the amount of $20 \mathrm{~mm}$ and more per day. The extreme values of mudflow-forming rains on the southern slope of the Greater Caucasus are $20-188 \mathrm{~mm}$, but in the region of the north-eastern slope of the Greater Caucasus and Gobustan 20-132 mm.

To estimate the synoptic situations leading to the formation of mudflows, the classification of atmospheric circulation types according to Dzerdzeevsky B.L. was also used. It was established that the mudflows in Azerbaijan are mainly formed under the subtype 12a (subtype of the northern meridional circulation) and 131 (the subtype of the southern meridional circulation, which prevails in the summer).

As a result, based on the interpretation of aerospace images (ASI), a map-scheme of the mudflow hazard was drawn up on the 5-point scale within the Azerbaijani part of the Greater Caucasus, where zones with a high (once in 2-3 years, 1 strong mudflow are possible) - V, with an average (once in 3-5 years, 1 strong mudflow is possible) - IV, with a weak (once in 5-10 years, 1 strong mudflow is possible) - III, with a potential mudflow hazard - II and where no mudflow processes are observed - I.

Keywords: mudflow, catastrophe, exo-dynamic processes, meteorological factor, types of circulation, anthropogenic factor.

\section{References}

1. Arclnfo Help. Glossary. Environmental Systems Research Institute (ESRI), Inc. February. 2001, 15 p.

2. Abu-Zeid N. Furlanis S. Oddone E. Debris-flow hazard assessment applying the resistivity imaging method: case study of Cancia Debris-Row Hazards Mitigation: Mechanics, Prediction, and Assessment, Rickenmann\& Chen (eds) (C) Millpress, Rotterdam, 2003, 12 p.

3. Huang C-J, Yin H.-Y.Experimental study of the underground sound generated by debris flows. Debris-Row
Hazards Mitigation: Mechanics, Prediction, and Assessment, Rickenmann\& Chen (eds) (C) Millpress, Rotterdam, 2003, 16 p.

4. Inaba H. Notes on the modeling of debris-flow surface images Debris-Row Hazards Mitigation: Mechanics, Prediction, and Assessment, Rickenmann \& Chen (eds.) (C) Millpress, Rotterdam, 2003, 15 p.

5. Mills K, Paul. J. Forest practices and mitigation of debris-flow risk in Oregon, USA. Debris-Row Hazards Mitigation: Mechanics, Prediction, and Assessment, Rickenmann\& Chen (eds) (C) Millpress, Rotterdam, 2003, 5 p.

6. Petrascheck A. Kienholz H. Hazard assessment and mapping of mountain risks in Switzerland. Debris-Row Hazards Mitigation: Mechanics, Prediction, and Assessment, Rickenmann\& Chen (eds) (C) Millpress, Rotterdam, 2003, 17 p.

7. Khadzhiyev M.M. Assessment of the mudflow hazard in the area of Tyrnyauz city. Author's abstract on Ph.D. Nalchik, 2005, 16 p. (in Russian)

8. BarinovA.Yu. Geomorphological analysis of the storm water hazard of the ShirokayaBalka gap (the Bleak Sea coast of the Caucasus). Geomorphology, 2010, no. 2, pp. 19-25. (in Russian)

9. Budagov B.A., Safarov S.G. Mudflow phenomena on the southern slope of the Greater Caucasus and the hydrometeorological factors of their formation Proceedings of the Russian Academy of Sciences. Series Geographic, 2008, no. 2, pp.116-121. (in Russian)

10. Alizade E.K., Tarikhazer S.A. Exomorphodynamics of the mountains relief and its estimation (on the example of the north-eastern slope of the Major Caucasus), Baku, Victory, 2010, 236 p.

11. Alizade E.K., Tarikhazer S.A. Ecogeomorphological danger and hazards at Greater Caucasus (in limits of Azerbaijan). Moscow, MAXPress, 2015, 207 p.

12. Nabiyev G.L. Mudflows in the Azerbaijan SSR and the conditions for their formation. Proceedings of the Academy of Sciences of Azerbaijan SSR, Earth Sciences Series, 1985, no. 6, pp. 76-81. (in Russian)

13. Kats A.L. Seasonal changes of general atmospheric circulation and long-term forecasting. Leningrad, Gidrometeoizdat, 1973, $270 \mathrm{p}$.

14. Vangeheim H.G. Experience in applying synoptic methods to the study of characteristics of the climate. Moscow, Gidrometeoizdat, 1935, 109 p.

15. Dzerdzeevsky B.L. General circulation and climate. Selected works. Moscow, 1975, 288 p. 
16. ShекоA.I. Formation regularity and forecasting of mudflows. Moscow, 1980, 296 p.

17. Tarikhazer S.A., Nabiyev G.L. Assessment of mudflow danger manifestations in Azerbaijan (on the example of the Greater Caucasus). Proceedings IX Int. Scientific Practice. Conf. "Mountain Areas: Priority Areas for Development", Vladikavkaz, 2017, no. 3(33), pp. 257-268 (in Russian)

18. Tarikhazer S. A. Mudflow processes in mountain geosystems of coastal zones of the Caspian sea (on the example of the north-eastern slope of the Greater Caucasus). ECOSF. Understanding the problems of inland waters: case study for the Caspian basin. 12-14 may 2018. Baku, 2018, pp. 187-191
19. Madatzade A.A. Synoptic conditions for heavy precipitation that cause flooding in Azerbaijan. Proceedings of the V All-Union Conference on the Study of Mudflows and measures to combat them. Baku, 1962. pp. 153-156. (in Russian)

20. Papinashvili K.I. Heavy rainfall in eastern Georgia and the aero-synoptic conditions of their occurrence. Proceedings of NIGMI. 1962, no. 10, pp. 101-112. (in Russian).

Article received 13.09.2018 


\section{ПРОБЛЕМЫ РЕКУЛЬТИВАЦИИ УГОЛЬНЫХ ШАХТ ДОНБАССА}

${ }^{1}$ Мадаева М.3.

${ }^{2}$ Хадзарагова Е.А., *

${ }^{2}$ Келехсаев В.Б., 'Олисаев А.С.

\section{Введение}

Россия обладает 16\% всех природных минерально-сырьевых ресурсов мира. Ее доля в мировых запасах составляет, \%: железа - более 27, никеля - 36, меди - 11, кобальта - 20, олова - 12 , цинка - 16 , металлов платиновой группы - 40. Стоимость сырья, ежегодно извлекаемого из недр России, по ценам мирового рынка составляет около 100 млрд. долларов. Сегодняшнее состояние минерально-сырьевой базы России характеризуется истощением богатых и крупных месторождений полезных ископаемых, поэтому повышается актуальность более полного и комплексного использования недр [1-4].

Донецкий угольный бассейн выдал первый уголь в 1723 г. В годы довоенных пятилеток построено более 100 новых шахт и первая в мире станция подземной газификации углей. После восстановления шахт в 1945 г. Донбасс давал угля больше, чем любой другой угольный бассейн СССР. С середины 70-х г. наметилась тенденция удорожания добычи угля при снижении его качества. Техническое перевооружение перспективных шахт осложнялось тем, что не было оборудования для работ в специфических условиях: малая мощность пластов, крепкие вмещающие породы, большая глубина разработки и интенсивное проявление горного давления. 1995-1997 гг. добыча угля была прекращена на 20 шахтах.

Россия испытывает дефицит в цветных, благородных и редкоземельных металлах, базой для производства которых могли бы быть хвосты обогащения угольных шахт. Вместе с этим обострилась проблема хранения отходов обогащения углей, отвалы которых являются неотъемлемой принадлежностью Донбасса. Проблема использования отходов особенно актуальна тем, что за 200 лет добычи каменных углей и антрацитов накоплено до 1300 терриконов общим объемом более 1 млрд. м³ на 5500 га земли. Техногенные месторождения доступны для эксплуатации технологиями переработки углеотходов, позволяя решать одновременно две важнейшие задачи - улучшение экологической обстановки и увеличение ресурсной базы минерального сырья.

Рекультивация породных отвалов является мерой восстановительного характера, направленной на устранение негативного воздействия горных работ на окружающую среду и рассматривается как основное направление восстановления ценности нарушенных земель и улучшения условий окружающей среды. Вся история и состояние Донбасса свидетельствуют о неэффективности процессов рекультивации [5-7]. Вначале это объяснялось недостаточной технической вооруженностью процессов рекультивации. Однако в новое время сформировалась проблема экономического плана. Захоронение и утилизация хвостов обогащения чреваты потерями ценных компонентов отвалов: металлов, в первую очередь, цветных, благородных и редкоземельных. Одна тонна угля Донецкого бассейна содержит, в граммах: 462 - иттрия, 595 - рубидия, 287 - серебра, 177 - тантала, 156 - гафния, 103 - тербия, 86 - лютеция, 27 - золота и т.д. В добыче донецких углей содержится драгоценных металлов по современным ценам на сумму, в 20 раз превышающую стоимость от проданных углей.

\footnotetext{
${ }^{1}$ Грозненский государственный нефтяной технический университет им. акад. М.Д. Миллионщикова, 364051, Грозный, Чеченская Республика, Россия

${ }^{2}$ Северо-Кавказский горно-металлургический институт (государственный технологический университет), 362021, Владикавказ, Россия, hadzaragova@mail.ru
}

УДК 504.55.054: 622 (470.6) DOI: 10.21177/1998-4502-2019$11-1-55-64$

Целью исследования является доказательство необходимости и возможности извлечения металлов из хвостов обогащения углей при рекультивации поверхности угольных шахт. Она может быть достигнута путем создания технологического процесса и комплекса оборудования для извлечения из отходов металлы до уровня санитарных требований. Методы исследования включают в себя анализ механизма влияния продуктов отвальных процессов на экосистемы окружающей среды и технологических схем обогащения и извлечения целевых химических элементов при рекультивации отвалов.

Результаты. Сформулирована проблема комплексного использования отходов обогащения угля. Дифрференцировано по районам и месторождениям региона исследованы и систематизированы свойства уәлесодержащих хвостов обогащения, как основа для их утилизации при рекультивации шахтной поверхности. Предложена типизация горелых пород по их функции в хранилищах хвостов. Описан механизм воздействия продуктов отвальных процессов на экосистемы окружающей среды. Диффференцированы по последствиям и ранжированы факторы влияния породных отвалов на окружающую среду. Показано, что отходы обогащения уеля, золы и шлаков, работающих на угле электростанций, могут использоваться для промышленного производства продуктов и материалов. Omмечено требование к использованию хвостов обогащения углей только после извлечения из них металлов до норм ПДК.

\section{КЛЮЧЕВЫЕ СЛОВА:}

хвосты обогащения, угли, утилизация, рекультивация, металлы, окружающая среда, Донбасс.

Статья поступила в редакцию 20.11.2018 
В настоящее время в стране накоплено более 12 млрд. т твердых отходов, в которых содержание ценных компонентов нередко выше, чем в рудах природных месторождений. В России ежегодно производится до 75 млн. т опасных отходов, 18\% из них утилизируются, а более $65 \%$ направляются в хранилища. Следствием существующего положения с использованием минеральных ресурсов является потеря до 20-30\% добытых запасов, что превышает добычу ресурсов ряда добывающих стран.

\section{Цели и задачи}

Целью исследования является доказательство необходимости включения в комплекс работ по рекультивации поверхности угольных шахт извлечение металлов из хвостов обогащения. Цель может быть достигнута решением задач совершенствования технологических процессов утилизации углей путем создания технологического процесса и комплекса оборудования для извлечения металлов из отходов производства.

\section{Методы исследования}

Сведения о свойствах и запасах углесодержащих хвостов и механизм их влияния на экосистемы окружающей среды систематизируются путем изучения истории шахт. Возможность использования отходов обогащения угля для промышленного производства для производства строительных и иных материалов, а также редких и рассеянных элементов доказывается анализом литературных источников. Количественное значение содержания химических элементов в отвалах угольных шахт приводится на основании результатов лабораторных исследований. Вывод о том, что традиционные технологии доизвлечения металлов не решают проблемы безотходности делается на основании данных о состоянии дел в угольной промышленности региона.

\section{Основная часть}

\section{Свойства углесодержаших хвостов}

Добываемая углесодержащая горная масса проходит обогащение с выделением товарного продукта и хвостов переработки. Отходы углеобогащения в отличие от пород угольных месторождений характеризуются более высоким содержанием угля, более стабильным вещественным составом, меньшим содержанием песчаников, большим содержанием аргиллитов, увеличением содержания серы и меньшей механической прочностью.

Хвосты обогащения углей складируют для постоянного хранения в отвалы.

В Российском Донбассе из 450 отвалов 340 или горят или уже сгорели. Породы перегоревших шахтных отвалов образовались в результате естественного обжига под влиянием высоких температур. Особенностью горелых пород является их пористость и наличие микротрещин при самообжиге. Наиболее сильно изменены аргиллиты, представленные спекшейся породой, содержащей металлы. Характерной чертой их является высокое содержание $\mathrm{Fe}_{2} \mathrm{O}_{3}$ (до 70\%).
Высокое содержание $\mathrm{Al}_{2} \mathrm{O}_{3}$ характерно для пород терриконов Донбасса. В Донецко-Макеевском районе Донбасса содержание $\mathrm{Al}_{2} \mathrm{O}_{3}$ составляет: в текущих отходах угледобычи - 23\%, отвалах обогатительных фабрик $-20 \%$, отходах флотации - $26 \%$, породных отвалах $-22 \%$. Высокое содержание глинозема отмечается в отвалах шахты им. Горького, №8 «Ветка», «Красногвардейская» - 26-27 \%. Хвосты углеобогатительных фабрик можно рассматривать как техногенные месторождения глинозема.

Нами выявлены высокие кларки концентрации $\mathrm{Ge}$, $\mathrm{Hg}, \mathrm{Cr}, \mathrm{Cu}, \mathrm{Cs}, \mathrm{Pb}, \mathrm{Ce}-1,47-30$ (в аргиллитах), $\mathrm{Hg}, \mathrm{Cr}$, $\mathrm{Th}, \mathrm{Pb}, \mathrm{Ce}, \mathrm{Zn}-1,27-6,5$ (в алевролитах), Sb, Sn, Ba, $\mathrm{Pb}, \mathrm{Cu}, \mathrm{Se}-10-150$ (в песчаниках). Хвосты флотационного обогащения обогатительных фабрик «Колосниковская», «Советская» и других характеризуются повышенным содержанием скандия (до 30 г/т), иттрия (до 30 г/т), галлия (до 45 г/т). Высокое содержание золота зафиксировано в отходах угледобычи шахты «Кировская-Западная» (Макеевуголь) и «Колосниковская» - до 60 раз превышающих кларки - 0,06 г/т.

Продуктами обжига пустых пород месторождений каменных углей, являются глинистые и глинисто-песчаные породы, обожженные в недрах земли при пожарах в угольных пластах, и отвальные перегоревшие шахтные породы. Их истинная плот-

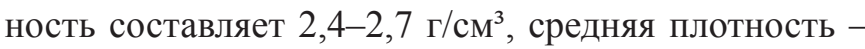

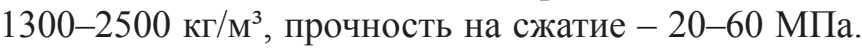
По основным физическим и химическим свойствам они близки к глинам, обожженным при $800-1000{ }^{\circ} \mathrm{C}$. Признаком для выделения их в особую разновидность, является наличие активного глинозема в виде радикалов дегидратированных глинистых минералов или активного глинозема, кремнезема и железистых соединений, что объясняет их высокую сорбционную способность. Содержание несгоревшего топлива достигает 2-3\% и более.

Наряду с природным сырьем, горелым относят и перегоревшие породы, содержащие менее $5 \%$ углистых примесей и обожженную минеральную глинисто-песчаную часть. Под действием кислорода воздуха уголь и сера возгораются, а порода под влиянием температуры до $1000{ }^{\circ} \mathrm{C}$ подвергается обжигу. Наиболее интенсивно горят породы в отвалах хвостов обогащения коксующихся или антрацитовых углей. Степень обжига горелых пород зависит от равномерности поступления влаги и воздуха. Обжиг происходит неравномерно, поэтому в результате образуется материал различной степени обжига с неодинаковыми физико-механическими свойствами. Например, размер частиц изменяется от 40 см до долей миллиметра. Горелые породы в целом однородны по химическому составу и содержат (по массе) $49-62 \% \mathrm{SiO}_{2} ; 20-40 \%$ $\mathrm{Al}_{2} \mathrm{O}_{3} ; 2-13 \% \mathrm{Fe}_{2} \mathrm{O}_{3} ; 1,5-3,5 \% \mathrm{CaO}$ и др.

Горелые породы, содержащие обожженные глинистые материалы, обладают активностью по отноше- 


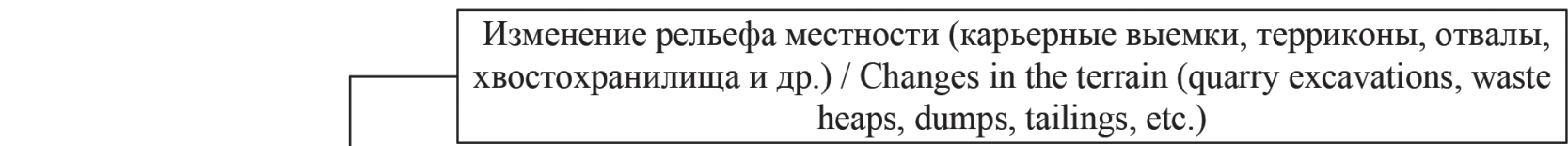

heaps, dumps, tailings, etc.)

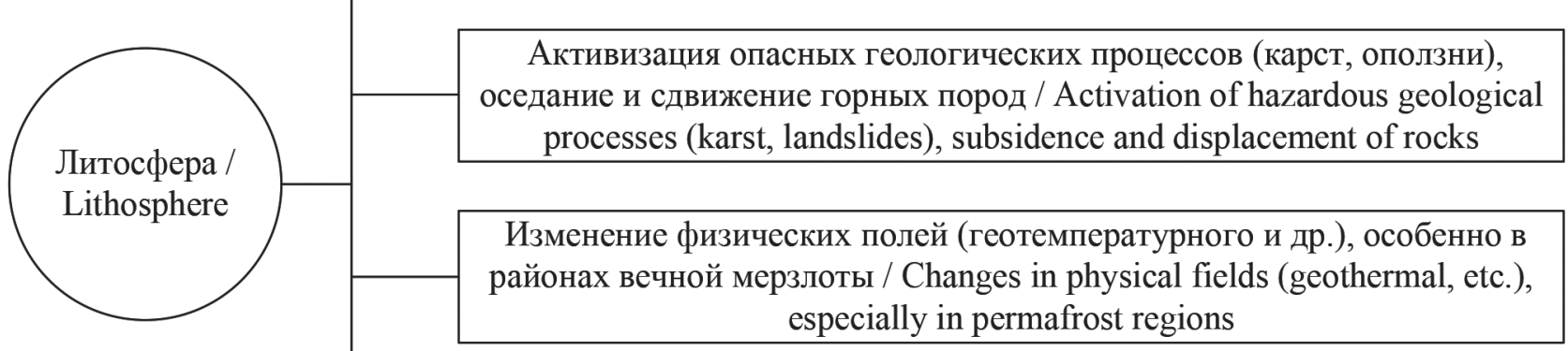

Химическое загрязнение почв, механическое нарушение почв / Chemical pollution of soil, mechanical violation of soil

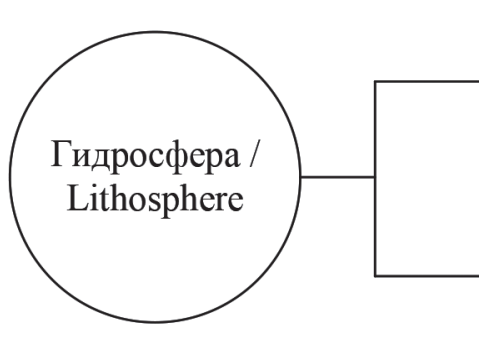

Истощение водоносных горизонтов и ухудшение качества подземных поверхностных вод / The depletion of aquifers and the deterioration of the quality of groundwater surface

Снижение расходов малых рек, чрезмерное осушение болот, почв и горных пород / Reducing the cost of small rivers, excessive drainage of wetlands, soils and rocks

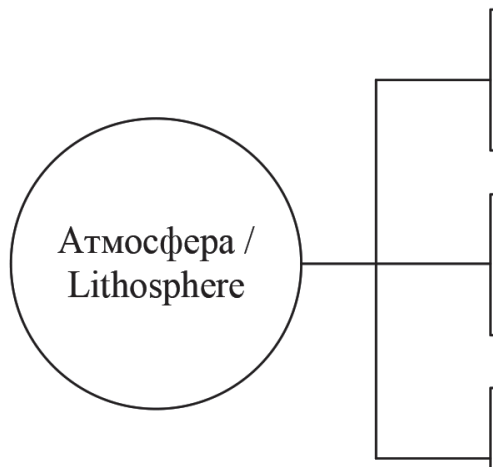

Загрязение атмосферного воздуха выбросами метана, оксидов углерода из горных выработок / Atmospheric air pollution by emissions of methane and carbon oxides from mine workings

Газовыделение и горение отвалов, терриконов (выделение оксидов азота, серы), газовые и нефтяные пожары / Gas emission and burning of dumps, piles (release of nitrogen oxides, sulfur), gas and oil fires

Выбросы пыли при взрывах в карьерах, обогащение пыли рудными элементами / Dust emissions from explosions in quarries, enrichment of dust with ore elements

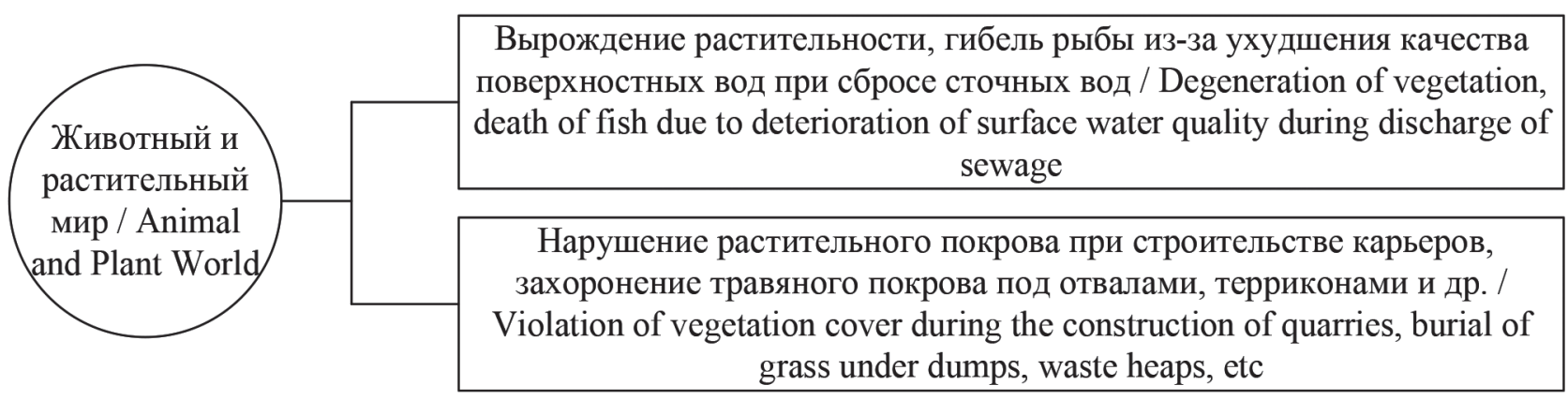

Рис. 1. Влияние отвалов обогащчения углей на окружающую среду

Fig. 1. Impact of coal processing dumps on the environment

нию к извести и используются как гидравлические добавки в вяжущих известково-пуццоланового типа, портландцементе, пуццолановом портландцементе и автоклавных материалах. Высокая адсорбционная активность и сцепление с органическими вяжущими позволяют применять их в композициях. Естественно обжигаемые аргиллиты, алевролиты и песчаники применяются в производстве жаростойких бетонов и пористых заполнителей. Некоторые горелые породы имеют пониженную плотность, что позволяет исполь- 
зовать их в качестве заполнителей для легких растворов и бетонов.

Активность дегидратированных глин зависит от строения кристаллической решетки и убывает от каолинита к гидрослюдам. Наряду с гидравлической активностью, характеризуемой поглощением извести, горелые породы характеризуют величиной адсорбционной активности.

Максимальную активность имеют породы, обожженные при 500-600 들 повышение температуры до 800-1000 ${ }^{\circ} \mathrm{C}$ активность снижает. В составе горелых пород выделяют типы:

- химически инертные пелиты;

-источники цементных минералов, концентраторы $\mathrm{S}, \mathrm{F}, \mathrm{Cl}$;

- источники токсичных газов, содержащие $\mathrm{S}, \mathrm{F}, \mathrm{N}, \mathrm{Cl}$;

- концентраторы $\left(\mathrm{SO}_{4}\right)^{2-}, \mathrm{Cl}^{-},\left(\mathrm{NH}_{4}\right)^{+}$- источники загрязнения почв и вод.

Среди качеств горелых пород особенно нежелательны водопоглощение и влажность, капиллярное всасывание и гидрофильный характер поверхности. Такими качествами обладают не полностью сгоревшие угольные частицы и легко вступающие в реакции с кислородом и водой колчеданы, например, пирит, марказит и др. Углистые и глинистые примеси обладают пониженной механической прочностью по сравнению с твердым керамическим черепком обожженной части и измельчаются естественным путем в отвале.

\section{Влияние на окружающую среду}

Отвал средних размеров выделяет в год 15 тыс. тонн $\mathrm{CO}_{2}, 5$ тыс. тонн $\mathrm{CO}$ и огромное количество пыли. Отвалы подразделяют на негорячие, нетоксичные; токсичные, горящие не антрацитовые; токсичные антрацитовые с интенсивным горением; терриконы обогатительных фабрик. Поверхностный слой отвалов выветривается и смывается водой. Он содержит практически все минеральные элементы, особенно много фосфора и калия. Неблагоприятное воздействие на флору оказывают значительная кислотность, наличие большого количества подвижных форм алюминия, малая влагоемкость и высокая температура почв в очагах горения.

В результате физического и химического выветривания порода разрушается и вместе с горючими газами является постоянно действующим источником загрязнения окружающей среды [8-12]. Водная эрозия отвалов характеризуется выносом с каждого гектара их поверхности в окружающую среду от 2,5 до 3,5 тонн породы, содержащей опасные компоненты. Снизить активность водной эрозии пытаются созданием искусственных насаждений и развитием самосевной древесной растительности.

Внутри отвалов создаются благоприятные условия для окисления, благодаря деятельности микроорганизмов. Окисление сульфидной серы осущест- вляется обычно автотрофными микроорганизмами, использующими $\mathrm{CO}_{2}$ и получающими энергию при окислении серы и ее продуктов. Микроорганизмы устойчивы в условиях кислой среды, но не переносят высокие температуры. Поэтому микроорганизмы начинают процесс окисления, который сопровождается выделением тепла, и разогревают определенную зону, а собственно горение протекает внутри террикона при доступе достаточного количества кислорода. Отвалы хвостов служат источниками загрязнения водной среды сульфатами и токсичными компонентами. При этом загрязняется поверхностный сток, выщелачивающий растворимые сульфаты с поверхности терриконов и почв, и подземные воды в процессе инфильтрации загрязненных атмосферных осадков. Отвалы занимают большие площади сельскохозяйственных земель, снижают производительность земель, загрязняют атмосферу газами и пылью, а также нарушают гидрогеологический режим местности (рис. 1). Токсичные воды отвалов уничтожают растительность на прилегающей территории, жизни людей.

Основными факторами негативного влияния породных отвалов на окружающую среду являются: нарушение естественного ландшафта земной поверхности; пылегазовые загрязнения атмосферы; нарушение гидрогеологического режима прилегающих территорий; химическое и радиологическое загрязнение почв и вод. Примерно 80 \% добываемого угля направляется на производство энергии, до 20 \% используется металлургической промышленностью. На всех этапах создаются хранилища хвостов обогащения и использования.

При добыче и обогащении углей на 1 т товарного угля образуется 3,3 т отходов. Ежегодно на территории России в процессе добычи угля из недр извлекается порядка 0,5 млрд. м ${ }^{3}$ горной массы, образуется около 60 млн. $\mathrm{M}^{3}$ минеральных отходов обогащения и 20 млн м ${ }^{3}$ шлаков. Используется лишь до 10\% накопленных минеральных ресурсов этого вида. На территории Восточного Донбасса функционируют более 450 отвалов шахт и обогатительных фабрик. В течение последних восьми лет на территории Ростовской области ежегодно образуется от 7 до 8 млн. т твердых промышленных отходов, около $50 \%$ из которых приходится на долю углеотходов. Борьба с негативным влиянием отвалов хвостов угледобычи включает в себя покрытие изолируемых хвостов изолирующими слоями земли с предотвращением выбросов, организацией поверхностного стока, предотвращением фильтрации атмосферных осадков в горизонты подземных вод, рекультивацией и озеленением (рис. 2).

Одним из способов снижения вредного воздействия считается озеленение терриконов с помощью лесных насаждений, которые позволяют регулировать 
поверхностный сток и сократить эрозионные процессы на поверхности отвалов.

\section{Направления утилизации хвостов}

В Российском Донбассе практически вся выдаваемая шахтами порода складируется в хранилища, которые пригодны для изготовления строительного кирпича, керамических изделий, стенового материала, бетонных заполнителей и других целей. Наиболее востребованы горелые породы, содержащие менее 5\% углистых примесей и обожженную глинисто-песчаную часть.

Горелые породы используются в качестве заполнителей в бетонах, которые после автоклавной обработки приобретают прочность до 30 МПа. Автоклавная обработка бетонов с заполнителями из горных пород дает возможность изготовлять блоки и панели, например, крепежные бетониты для крепления горных подземных выработок. Хвосты обогащения углей пригодны для получения глинозема $\left(\mathrm{Al}_{2} \mathrm{O}_{3}\right)$ с последующей выплавкой алюминия. Глинозем и алюминий получают из бокситов, содержащих глинозем более 26-28\%. Минеральные отходы добычи и обогащения угля, золы и шлаки электростанций, работающих на угле, могут использоваться для промышленного производства глинозема, коагулянтов для очистки воды, абразивных и жаропрочных сплавов, раскислителей для сталелитейного производства, строительных материалов, редких и рассеянных элементов и других продуктов и материалов [13-15].

Достигнуты успехи при получении жидких продуктов из некондиционных углесодержащих минералов методом гидрогенизации под давлением от 6 до 600 МПа. Бурые и окисленные каменные угли содержат гуминовые кислоты, которые могут быть выделены растворами щелочей в виде водорастворимых солей - стимуляторов роста растений.

Сферические и мелкозернистые адсорбенты из каменных углей с регулируемой пористостью пригодны для очистки сточных вод от органических примесей, выделения золота и серебра из цианистых растворов и получения чистого азота и др.

На основе бурого угля производят мелкозернистые активные угли для очистки воды и выделения благородных металлов. В отходах обогащения бурых углей содержится горный воск, используемый для точного литья и в качестве добавок к пластификаторам, лакам, краскам и кремам. Углепластики применяются в строительстве сооружений для защиты фундаментов зданий. В крупнопанельном строительстве используют углеродсодержащие герметики на базе композиций полиизобутилена или полиэтилена. Для покрытия полов и дорог применяют эпоксидные углепластики. Из полимеров этилена и эфиров акриловой кислоты в смеси с углем получают быстровысыхающие мастики.

Угольная пыль, вводимая в изделия из полиэтилена, заменяет дефицитную сажу, а в эбонитовых изделиях снижает расход серы.

Углеграфитовые материалы применяются в производстве стали, алюминия, полупроводниковых материалов, в атомной энергетике, авиации и т. п.

Углесодержащая порода верхней вскрыши служит исходным сырьем для производства абразивных и огнеупорных материалов.

Минеральные компоненты углей являются сырьем для производства легких пористых заменителей для бетона - аглопоритов и строительной керамики.

Отходы угледобычи используются для планировки территорий, подсыпки дорог, для производства строительной керамики. А отходы, содержащие углерод, являются сырьем для изготовления высококачественных керамических стеновых материалов и легких пористых заполнителей.

Прототипом технологии утилизации отходов угледобычи является метод HALDEX (Венгрия). При обогащении углесодержащих отходов из угольных отвалов конечными продуктами являются уголь (30-10 мм, 0-10 мм) и сланцы. Сланцы используют-

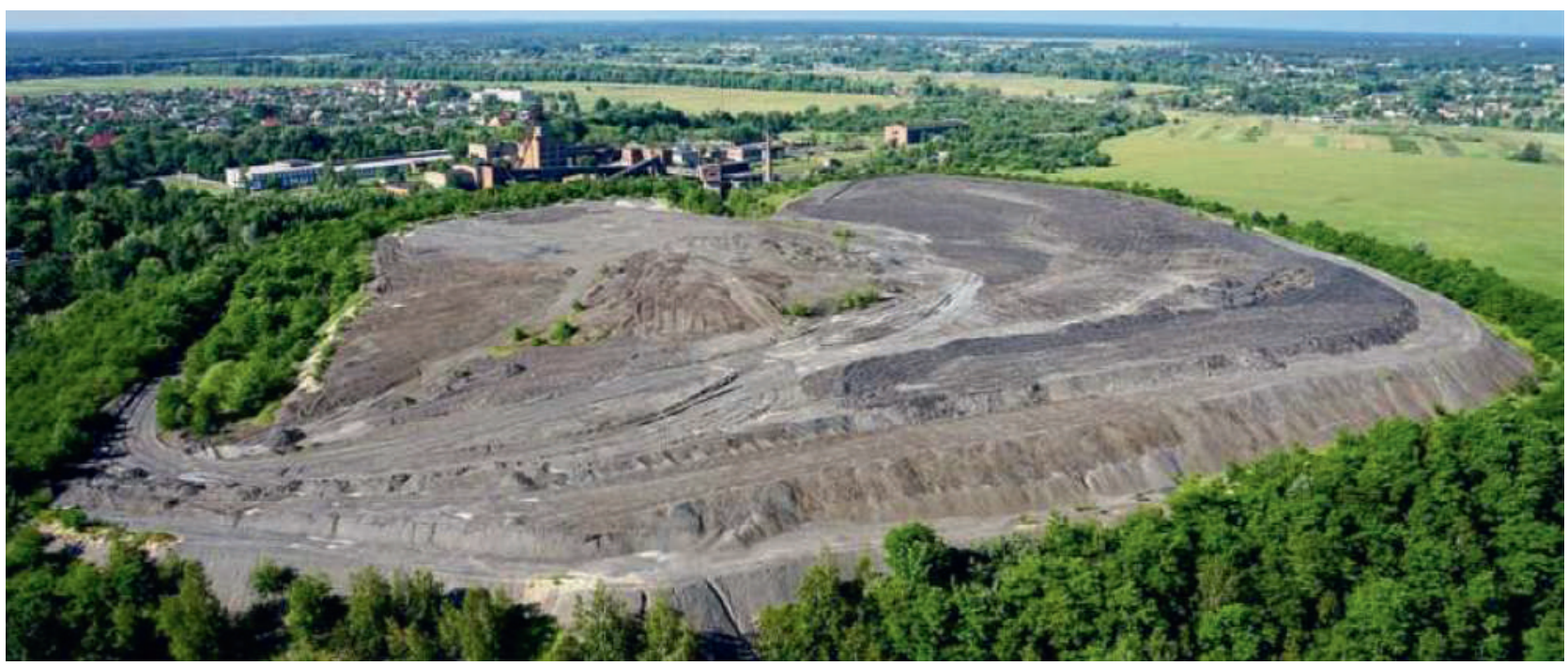

Pис. 2. Рекультиваџия отвала хвостов обогащуения углей

Fig. 2. Reclamation of coal enrichment tailings dump 
ся в производстве цемента, строительной керамики, кирпича, легких агрегатов, его добавляют в бетонные смеси. Фракции размером от 3 до 30 мм используются в качестве закладочных материалов для шахт.

Шламы от флотации каменного угля используют как топливо после уменьшения влаги до 8-10 \%. Шламы бурого угля используют в сельском хозяйстве. Гумусовые кислоты, содержащиеся в них, улучшают структуру почв, положительно влияют на стабилизацию кислотности почв и способствуют разложению минеральных соединений для усвоения растениями.

Утилизируемые угольные массы используют для изготовления питательных белков и удобрений.
Углеудобрения применяют для защиты водохранилищ и рек.

Полное и безотходное преобразование потребляемых ресурсов в потребительские товары в России не обеспечивается. Особо остро обстоит положение в угольном производстве. В последнее время побеждает тенденция моратория на использование хвостов обогащения углей без извлечения из них металлов до норм ПДК.

\section{Технология утилизации хвостов}

Основу пристального внимания к проблеме утилизации хвостов обогащения углей составляет наличие в них неизвлеченных металлов. Содержание металлов в отвалах угольных шахт приводится в табл. 1.

Содержание химических элементов в отвалах угольных шахт, г/т

Таблица 1 / Table 1

The content of chemical elements in the dumps of coal mines, $g / t$

\begin{tabular}{|c|c|c|c|c|c|c|c|}
\hline $\begin{array}{l}\text { Элемент } \\
\text { Element }\end{array}$ & $\begin{array}{c}\text { Каменско-Гун- } \\
\text { доровский } \\
\text { Kamensko-Gun- } \\
\text { dorovsky }\end{array}$ & $\begin{array}{c}\text { Белокалит- } \\
\text { винский } \\
\text { Belokalitvinskiy }\end{array}$ & $\begin{array}{c}\text { Гуково-Зве- } \\
\text { ревский } \\
\text { Gukovo- } \\
\text { Zverevskiy }\end{array}$ & $\begin{array}{c}\text { Красно-До- } \\
\text { нецкий } \\
\text { Krasno- } \\
\text { Donetskiy }\end{array}$ & $\begin{array}{c}\text { Сулино-Сад- } \\
\text { кинский } \\
\text { Sulino-Sadkinskiy }\end{array}$ & \begin{tabular}{|c|} 
Шахтинско-Не- \\
светаевский \\
Shakhtinsko- \\
Nesvetaevskiy
\end{tabular} & $\begin{array}{l}\text { ПДК } \\
M P C\end{array}$ \\
\hline \multirow[t]{2}{*}{$\mathrm{Mn}$} & $300-700$ & $100-600$ & $200-600$ & $200-600$ & $200-500$ & $100-1000$ & 1500 \\
\hline & 430 & 310 & 350 & 380 & 330 & 380 & \\
\hline \multirow[t]{2}{*}{$\mathrm{Ni}$} & $40-80$ & $10-30$ & $10-100$ & $15-30$ & $30-50$ & $10-100$ & 4 \\
\hline & 40 & 10 & 40 & 20 & 40 & 40 & \\
\hline \multirow[t]{2}{*}{ Co } & $10-20$ & & & & $10-20$ & & 5 \\
\hline & 15 & & & & 12 & & \\
\hline \multirow[t]{2}{*}{ V } & $80-200$ & $30-100$ & $60-200$ & $50-80$ & $80-150$ & $50-500$ & 150 \\
\hline & 120 & 60 & 110 & 60 & 90 & 130 & \\
\hline \multirow[t]{2}{*}{$\mathrm{Cr}$} & $100-200$ & $30-100$ & $50-200$ & $50-60$ & & $50-200$ & 6 \\
\hline & 140 & 70 & 110 & 50 & & 120 & \\
\hline \multirow[t]{2}{*}{$\mathrm{Zr}$} & $50-100$ & $10-100$ & & $60-100$ & $60-150$ & $50-150$ & $\mathrm{H} / \mathrm{H}$ \\
\hline & 60 & 70 & & 70 & 90 & 80 & \\
\hline \multirow[t]{2}{*}{$\mathrm{Pb}$} & $10-30$ & & $10-100$ & $20-300$ & $10-20$ & $15-3000$ & 30 \\
\hline & 20 & & 30 & 70 & 20 & 90 & \\
\hline \multirow[t]{2}{*}{$\mathrm{Zn}$} & & & & & $30-50$ & & 37 \\
\hline & & & & & 40 & & \\
\hline \multirow[t]{2}{*}{$\mathrm{Be}$} & & & & & $1,5-3,0$ & & $\mathrm{H} / \mathrm{H}$ \\
\hline & & & & & 2 & & \\
\hline
\end{tabular}


Содержание металлов в хранилищах ОФ приведено в табл. 2.

Таблица 2 / Table 2

Содержание химических элементов в хранилищах ОФ, г/т

Content of chemical elements in storages of concentrating factory, $g / t$

\begin{tabular}{|c|c|c|c|c|c|c|c|c|c|c|c|}
\hline \multirow{2}{*}{$\begin{array}{c}\text { Обогатительная фабрика } \\
\text { Concentrating factory }\end{array}$} & \multicolumn{11}{|c|}{$\begin{array}{c}\text { Содержание элементов, г/т } \\
\text { Content of elements, } g / t\end{array}$} \\
\hline & $\mathrm{Mn}$ & $\mathrm{Ni}$ & Co & $\mathrm{V}$ & $\mathrm{Cr}$ & Mo & $\mathrm{Zr}$ & $\mathrm{Pb}$ & $\mathrm{Zn}$ & $\mathrm{Be}$ & $\mathrm{Sr}$ \\
\hline $\begin{array}{l}\text { Донецкая } \\
\text { Donetskaia }\end{array}$ & 640,9 & 74,2 & 17,4 & 124,0 & 222,1 & 5,0 & 113,6 & 74,0 & 149,1 & 3,0 & 175,2 \\
\hline $\begin{array}{l}\text { Гуковская } \\
\text { Gukovskaia }\end{array}$ & 989,4 & 39,7 & 14,9 & 79,9 & 148,6 & 5,6 & 99,0 & 49,8 & 83,7 & 4,0 & 594,3 \\
\hline $\begin{array}{l}\text { Шолоховская } \\
\text { Sholokhovskaia }\end{array}$ & 324,1 & 55,2 & 24,1 & 242,0 & 242,0 & 6,2 & 104,2 & 55,5 & 263,0 & 2,6 & 356,4 \\
\hline $\begin{array}{l}\text { Несветаевская } \\
\text { Nesvetaevskaia }\end{array}$ & 790,5 & 49,6 & 10,4 & 99,3 & 198,0 & 3,0 & 99,0 & 39,9 & 148,8 & 3,0 & 151,0 \\
\hline
\end{tabular}

таблица 3 / Table 3

Кларки концентраций некоторых металлов в отходах

Clarks of concentrations of certain metals in waste

\begin{tabular}{|l|c|c|c|c|c|c|c|c|c|c|}
\hline \multicolumn{1}{|c|}{$\begin{array}{c}\text { Район } \\
\text { Area }\end{array}$} & $\mathbf{M n}$ & $\mathbf{N i}$ & $\mathbf{C o}$ & $\mathbf{V}$ & $\mathbf{C r}$ & $\mathbf{M o}$ & $\mathbf{Z r}$ & $\mathbf{P b}$ & $\mathbf{Z n}$ & $\mathbf{B e}$ \\
\hline $\begin{array}{l}\text { Каменско-Гундоровский } \\
\text { Kaтеnsko-Gundorovskiy }\end{array}$ & 0,43 & 0,69 & 0,83 & 1,33 & 1,67 & 0,91 & 0,35 & 1,25 & 0,48 & 0,53 \\
\hline $\begin{array}{l}\text { Белокалитвенский } \\
\text { Belokalitvenskiy }\end{array}$ & 0,31 & 0,17 & 0,17 & 0,67 & 0,84 & 1,09 & 0,41 & 1,25 & 0,12 & 0,53 \\
\hline $\begin{array}{l}\text { Гуково-3веревский } \\
\text { Gukovo-Zverevskiy }\end{array}$ & 0,35 & 0,69 & 0,61 & 1,22 & 1,33 & 0,91 & 0,41 & 1,88 & 0,36 & 0,68 \\
\hline $\begin{array}{l}\text { Краснодонецкий } \\
\text { Krasnodonetskiy }\end{array}$ & 0,38 & 0,34 & 0,28 & 0,67 & 0,60 & 1,82 & 0,41 & 4,38 & 0,36 & 0,66 \\
\hline $\begin{array}{l}\text { Сулино-Садкинский } \\
\text { Sulino-Sadkinskiy }\end{array}$ & 0,33 & 0,69 & 0,67 & 1,00 & 0,96 & 0,82 & 0,53 & 1,22 & 0,48 & 0,53 \\
\hline $\begin{array}{l}\text { Шахтино-Несветаевский } \\
\text { Shakhtino-Nesvetaevskiy }\end{array}$ & 0,38 & 0,69 & 0,67 & 1,44 & 1,45 & 0,91 & 0,47 & 5,63 & 0,36 & 0,53 \\
\hline
\end{tabular}

Повышенные кларки концентрации (КК) ванадия и хрома установлены в Каменско-Гундоровском (1,33 и $1,67)$, Гуково-Зверевском $(1,22$ и 1,33$)$ и ШахтинскоНесветаевском $(1,44$ и 1,45$)$ районах; молибдена - в Белокалитвенском $(1,09)$ и Краснодонецком $(1,82)$ районах (табл. 3). С помощью регрессионных полнофакторных моделей второго порядка, полученных на основе статистических исследований репрезентативных выборок среднего объема, определено, что для Восточного Донбасса характерно повышенное содержание свинца, кларки концентрации которого изменяются от 1,22 (Сулино-Садкинский район) до 5,63 (Шахтинско-Несветаевский район) и составляют в среднем 3,33 .

Рекультивация отвалов хвостов обогащения углей рассматривается как направление восстановления хозяйственной ценности нарушенных земель и улучшения условий окружающей природной среды [16; 17].

Работы по рекультивации обычно выполняются в два этапа - технический и биологический. Технический этап включает в себя планировку поверхности и покрытие ее плодородным слоем. Биологический этап включает в себя агротехнические меры по восстановлению плодородия, ускорению почвообразовательных процессов, возобновлению флоры и фауны на некультивированных землях.

Основные технические решения по рекультивации:

- обрушение нависающих массивов отвала;

- послойная разборка отвала с охлаждением методом дождевания и отбором породы;

- выполаживание откосов до угла не более $25^{\circ}$;

- складирование потушенной породы с предотвращением самовозгорания;

- формирование изоляционного слоя на площади размещения отвала толщиной не менее $0,5 \mathrm{~m}$;

- уплотнение сформированных плато и откосов отвала;

- посев растений.

После завершения горнотехнического этапа рекультивации выполняется биологическая рекультивация с целью создания прекращающей процессы дефляции и водной эрозии дернины.

Хвостохранилища угольных предприятий являются перспективной минерально-сырьевой базой ряда 
ценных металлов. Реализация перспектив зависит от успеха создания новых технологических схем обогащения и извлечения целевых химических элементов.

Традиционные технологии доизвлечения металлов не решают проблемы безотходности, поскольку порождают новые хвосты с ограниченным применением [18-21].

\section{Выводы}

1. Препятствием для безотходной утилизации хвостов обогащения углей является практически полное отсутствие технологий извлечения из них металлов до уровня, отвечающего требованиям санитарной безопасности.

2. Металлические примеси в углях являются заключенным в минеральные матрицы продуктом природного выщелачивания руд и могут быть извлечены в процессе, обратном процессу их образования в недрах, путем приложения высокой энергии.

3. Технологии полного безотходного и рентабельного извлечения металлов из углесодержащих пород ждут своего развития.

\section{ЛИТЕРАТУРА:}

1. Голик В.И., Ермоленко А.А., Лазовский В.Ф. Организационно-экономические проблемы использования природных ресурсов Южного Федерального округа. Краснодар, $2008.328 \mathrm{c}$.

2. Khasheva Z.M., Golik V.I. The ways of recovery in economy of the depressed mining enterprises of the Russian Caucasus // International Business Management. 2015. T. 9. N 6. C. $1210-1216$.

3. Bian Zhengfu, Miao Xiexing, Shaogang Lei, Chen Shenen, Wang Wenfeng, Struthers Sue. The challenges of reusing mining and mineral-processing wastes // Science. 2012. Vol. 337. No. 6095. Рp. 702-703.

4. Хулелидзе К.К., Кондратьев Ю.И., Бетрозов 3.С., Заалишвили В.Б. Оценка коренных и техногенных месторождений РСО-Алания как возможных объектов применения технологии подземного и кучного выщелачивания // Устойчивое развитие горных территорий. 2016. Т. 8. N1. С. 46-51.

5. Геоэкологическая оценка эффективности защиты окружающей среды и природо-охранительных мероприятий при подземной добыче угля/ Н.М. Качурин, Г.В. Стась, С.3. Калаева, Т.В. Корчагина // Известия Тульского государственного университета. Сер. Науки о Земле. Вып. 3. 2016. C. $62-79$.

6. Молев М.Д., Молев, А.М, Теория и практика управления региональной экологической безопасностью: монография. Шахты: Изд-воЮРГУЭС, 2006. 84 с.

7. Packey D. J. Multiproduct mine output and the case of mining waste utilization // Resour. Policy. 2012. V. 37. No. 1. Pp. 104-108.

8. Воробьев А.Е., Голик В.И., Пагиев К.Х., Цирихова Э.М., Котенко Е.А., Шестаков В.А., ИсаевК.С. Наукоемкие технологии добычи и переработки руд. Владикавказ, 1998. $571 \mathrm{c}$.

9. Качурин Н.М., Поляков В.В., Ефимов В.И., Стась Г.В. Загрязнение атмосферы топливно-энергетическим комплексом при использовании углей Подмосковного бассейна. Тула: ИПП «ГрифиКО ${ }^{\circ}, 2004.227$ с.

10. Capilla A. V., Delgado A. V. The destiny of the earth's mineral resources. London: World Scientifi c Publishing Co. Pte. Ltd., 2015.Dubiński J. Sustainable Development of Mining Mineral Resources // J. Sustain. Min. 2013. Vol. 1. P. 1-6.

11. Васильев П.В., Рыбак В.Л., Егорова Т.А. Методика оценки воздействий породных отвалов шахт на окружающую среду и мероприятия по их локализации // Известия ТулГУ. Науки о Земле. Вып.2. 2016. С.3-19.

12. Комащенко В.И. Эколого-экономическая целесоо-

бразность утилизации горнопромышленных отходов с целью их переработки // Известия Тульского государственного университета. Науки о Земле. 2015. N 4. С. 23-30.

13. Ghorbani Y., Franzidis J.-P., Petersen J. Heap Leaching Technology - Current State, Innovations, and Future Directions: A review // Mineral Processing and Extractive Metallurgy Review. 2016. Vol. 37. No. 2. Pp. 73-119.

14. Doifode S. K., Matani A. G. Effective Industrial Waste Utilization Technologies towards Cleaner Environment // International Journal of Chemical and Physical Sciences. 2015. Vol. 4. Special Issue. NCSC. Pp. 536-540.

15. Крупская Л. Т., Голубев Д. А., Волобуева Н. Г. Оценка экологической ситуации территории в зоне влияния хвостохранилища с токсичными отходами // Современные тенденции развития науки и технологий. 2016. N 1-2. С. 97-100.

16. Дмитрак Ю.В., Камнев Е.Н. АО "Ведущий проектноизыскательский и научно-исследовательский институт промышленной технологии" - путь длиной в 65 лет // Горный журнал. 2016. N 3. С. 6-12.

17. Каплунов Д. Р., Рыльникова М. В., Радченко Д. Н. Научно-методические основы проектирования экологически сбалансированного цикла комплексного освоения и сохранения недр Земли // Горный информационно-аналитический бюллетень. 2015. N 4 (специальный выпуск № 15). C. $5-11$.

18. Rolf Dieter Stoll, Christian Niemann-Delius, Carsten Drebenstedt, KlausMüllensiefen: Der Braunkohlentagebau. Bedeutung, Planung, Betrieb, Technik, Umwelt. Springer-Verlag, Berlin, Heidelberg. 2009. P. 605.

19. Polukhin O.N., Komashchenko V.I., Golik V.I., Drebenstedt C. Substantiating the possibility and expediency of the ore beneficiation tailings usage in solidifying mixtures production // Scientific Reports on Resource Issues Innovations in Mineral Ressource Value Chains: Geology, Mining, Processing, Economics, Safety, and Environmental Management. Freiberg, 2014. Pp. 402-412.

20. Кондратьев Ю.И., Дзеранова К.Б., Малиева 3.В., Москвичева И.Ю. Выщелачивание полиметаллических руд серно-кислотно-хлоридными растворами на основе дегазированной воды с добавкой поверхностно-активного вещества // Устойчивое развитие горных территорий. 2013. Т. 5. N 1. C. 57-54.

21. Каплунов Д. Р. Теоретические основы проектирования освоения недр: становление и развитие // Горный журнал. 2014. N 7. С. 49-51. 


\section{СВЕДЕНИЯ ОБ АВТОРАХ / Information about authors:}

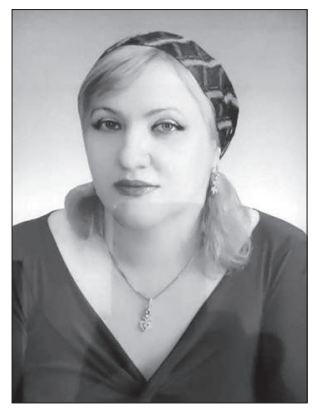

МАДАЕВА Марет Зайндиевна аспирант, старший преподаватель кафедры “Теплотехника и гидравлика", Грозненский государственный нефтяной технический университет имени акад. Миллионщикова.

364051, г. Грозный, Чеченская Республика, Россия

Maret Z. MADAEVA-Postgraduate ment "Hydraulics and Heat Engineering".

Student, Senior Lecturer of the DepartM.D. Millionshchikov Grozny State Oil Technical University. 364051, Grozny, Chechen Republic, Russia.

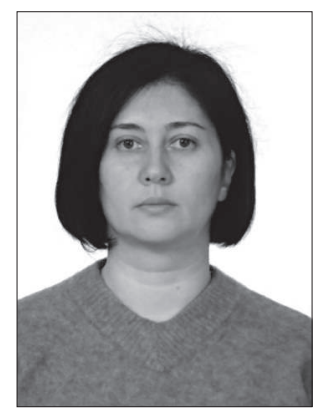

ХАДЗАРАГОВА Елена Александровна - доктор технических наук, профессор, заведующая кафедрой, проректор, Северо-Кавказский горно-металлургический институт (государственный технологический университет).

362021, г. Владикавказ, Россия

hadzaragova@mail.ru

Elena A. KHADZARAGOVA - Doctor of Technical Sciences, Professor, Head of Department, Vice-Rector, North-Caucasian Institute of Mining and Metallurgy (State Technological University).

362021, Vladikavkaz, Russia.

hadzaragova@mail.ru

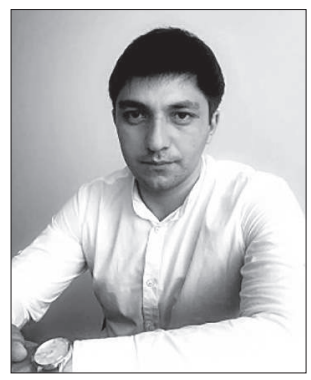

КЕЛЕХСАЕВ Валерий Борисович - ассистент кафедры "Горное дело", Северо-Кавказский горно-металлургический институт (государственный технологический университет).

362021, Владикавказ, Россия. Тел.: 8-962-747-61-11.

Valeriy B. KELEKHSAEV - assistent, Department "Mining". North-Caucasian Institute of Mining and Metallurgy (State Technological University).

362021, Vladikavkaz, Russia.

Ph.: 8-962-747-61-11.

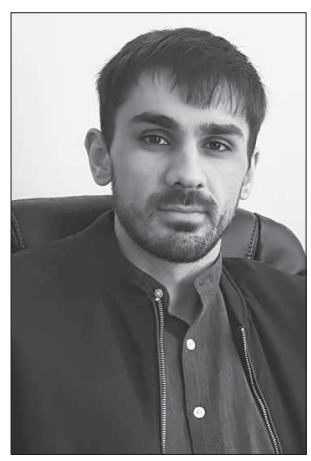

ОЛИСАЕВ Аслан Сергеевич - старший преподаватель кафедры «Организация промышленности и экономика предприятий». Северо-Кавказский горно-металлургический институт (государственный технологический университет).

362021, г. Владикавказ, ул. Николаева, 44.

Aslan S. OLISAEV - Senior Lecturer, Departament "Production Organization and Economy of Enterprises". North-Caucasian Institute of Mining and Metallurgy (State Technological University).

362021, Vladikavkaz, Russia.

\section{PROBLEMS OF DONBASS COAL MINES RECULTIVATION}

${ }^{1}$ M. Z. Madaeva,

${ }^{2}$ E. A. Khadzaragova,*

${ }^{3}$ V. B. Kelekhsaev,

${ }^{3}$ A. S. Olisaev

${ }^{1}$ M.D. Millionshchikov Grozny State Oil Technical University, 364051, Grozny, Chechen Republic, Russia.

${ }^{2}$ North-Caucasian Institute of Mining and Metallurgy (State Technological University), 362021, Vladikavkaz, Russia, hadzaragova@mail.ru

DOI: $10.21177 / 1998-4502-2019-11-1-55-64$

The purpose of the study is to prove the necessity and possibility of extracting metals from coal tailings during the recultivation of the coal mines surface. It can be achieved by creating a technological process and a complex of equipment for extracting metals from waste to the level of sanitary requirements.

Research methods include the analysis of the mechanism of influence of waste products on the ecosystems of the environment and technological schemes of enrichment and extraction of target chemical elements during the reclamation of dumps.
Results. The problem of complex use of coal wastes is formulated. Differentiated by regions and deposits of the region, the properties of coal-containing tailings of the beneficiation were investigated and systematized, as a basis for their utilization during the mine surface recultivation. The typification of burned rocks according to their function in tailings storages is proposed.

The mechanism of the impact of waste dump products on the ecosystem of the environment is described. Differentiated by consequences and factors of influence of waste dumps on the environment are ranked. It is shown that wastes from the 
enrichment of coal, ash, and slags from coal-fired power plants can be used for industrial production of products and materials. Noted the requirement for the use of coal tailings only after the extraction of metals from them to the MPC standards. The quantitative value of the content of chemical elements in the dumps of coal mines is given.

Identified technical solutions for the rehabilitation of the mine surface. The role of tailing dumps in the creation of a new, almost unlimited mineral and raw material base for the production of metals using new technological schemes for enrichment and extraction of chemical elements is shown.

Conclusion. Traditional technologies for the extraction of metals do not solve the problem of wastelessness, since metallic impurities in coals are the product of natural leaching of ores enclosed in mineral matrices, and can only be extracted by applying high energy during innovative leaching processes.

Keywords: tailings, coal, utilization, reclamation, metals, environment, East Donbass.

\section{References}

1. Golik V. I., Ermolenko A. A., Lazovsky V. F. Organizational and economic problems of use of natural resources of the southern Federal district. Krasnodar, 2008. 328 p.

2. Khasheva Z.M., Golik V.I. The ways of recovery in economy of the depressed mining enterprises of the Russian Caucasus. International Business Management. 2015. Vol. 9. no. 6. pp. 1210-1216.

3. BianZhengfu, Miao Xiexing, Shaogang Lei, Chen Shenen, Wang Wenfeng, Struthers Sue. The challenges of reusing mining and mineral-processing wastes. Science. 2012, Vol. 337 , no. 6095 , pp. 702-703.

4. Khulelidze K.K., KondratievYu.I., Betrozov Z.S., Zaalishvili V.B. Estimation of primary and technogenic deposits of the Republic of North Ossetia-Alania as possible objects for the application of underground and heap leaching technology. Sustainable Development of Mountain Territories. Vladikavkaz, 2016, V. 8., no. 1, pp. 46-51.

5. Geoecological assessment of the effectiveness of environmental protection and environmental protection measures in underground coal mining / N. M. Kachurin, G. V. Stas, S. Z. Kalaeva, T. V. Korchagina. News of Tula State University. Ser. Earth Science. Issue. 3, 2016, pp. 62-79.

6. Molev M. D., Molev, A.m., Theory and practice of regional environmental safety management: monograph. Mine: Publishing House of Argues, 2006. 84 p.

7. Packey D. J. Multiproduct mine output and the case of mining waste utilization. Resour. Policy. 2012, Vol. 37, no. 1, pp. 104-108.

8. Vorobiev.E., Golik V. I., Pagiev K. H., Chirikova E. M., Kotenko E. A., Shestakov V. A., Isaev K. S. High technologies of extraction and processing of ores. Vladikavkaz, 1998, 571 p.

9. Kachurin N. Mmm. Polyakov V. V., Efimov V. I., Stas G. $\mathrm{V}$. Air pollution by fuel and energy complex using coal of the Moscow region basin. Tula: GRIF \& CO., 2004. 227 p.
10. Capilla A. V., Delgado A. V. The destiny of the earth's mineral resources. London: World Scientifi c Publishing Co. Pte. Ltd., 2015.Dubiński J. Sustainable Development of Mining Mineral Resources. J. Sustain. Min. 2013, Vol. 1, pp. 1-6.

11. Vasiliev P. V., Rybakov.L., Egorova T. A. Methods of impact assessment of waste dumps of mines on the environment and measures for their localization. Proceedings of the Tula State University. Earth science. Issue. 2, 2016, pp. 3-19.

12. Tomashenko, V. I. Ecological and economic feasibility of disposal of mining waste with the purpose of their processing. Proceedings of the Tula State University. Earth Science. 2015, no. 4, pp. 23-30.

13. Ghorbani Y., Franzidis J.-P., Petersen J. Heap Leaching Technology - Current State, Innovations, and Future Directions: A review. Mineral Processing and Extractive Metallurgy Review. 2016, Vol. 37, no. 2, pp. 73-119.

14. Doifode S. K., Matani A. G. Effective Industrial Waste Utilization Technologies towards Cleaner Environment. International Journal of Chemical and Physical Sciences. 2015, Vol. 4, Special Issue. NCSC. pp. 536-540.

15. Krupskaya L. T., Golubev D. A., Volobueva N. D. Assessment of the ecological situation of the territory in the zone of influence of the tailings pond with toxic waste. Modern Trends in the Development of Science and Technology. 2016, no. 1-2, pp. 97-100.

16. Dmitrak Yu. V., Kamnev E. N. And About "the Leading design and survey and research Institute of industrial technology" - a path of 65 years. Mining Journal. 2016, no 3, pp. 6-12.

17. Kaplunov D. R., Ryl'nikova M. V., Radchenko D. N. Scientific-methodical bases of designing ecologically balanced cycle of complex development of bowels of the Earth. Mining Information-Analytical Bulletin. 2015, no. 4 (special issue no. 15$)$, pp. 5-11.

18. Rolf Dieter Stoll, Christian Niemann-Delius, Carsten Drebenstedt, KlausMüllensiefen: Der Braunkohlentagebau. Bedeutung, Planung, Betrieb, Technik, Umwelt. Springer-Verlag, Berlin, Heidelberg. 2009, 605 p.

19.Polukhin O.N., Komashchenko V.I., Golik V.I., Drebenstedt C. Substantiating the possibility and expediency of the ore beneficiation tailings usage in solidifying mixtures production. Scientific Reports on Resource Issues Innovations in Mineral Ressource Value Chains: Geology, Mining, Processing, Economics, Safety, and Environmental Management. Freiberg, 2014, pp. 402-412.

20. Kondrat'ev, Yu. I., Dzeranova K. B., Z. V. Maleeva, I. Moskvicheva Y. Leaching of polymetallic ores the sulphuric acid-chloride solutions on the basis of degassed water with the addition of surface-active agents. Sustainable Development of Mountain Territories. 2013, V. 5., no. 1, pp. 57-54.

21.Kaplunov D. R. Theoretical bases of design of development of subsoil: formation and development. Mining Journal. 2014, no. 7, pp. 49-51.

Article received 20.11.2018 


\title{
ТЕХНИЧЕСКИЕ НАУКИ
}

\author{
ENGINEERING
}

Если бы я захотел читать, еще не зная букв, это было бы бессмыслицей.

Точно так же, если бы я захотел судить о явлениях природы, не имея никакого представления о началах вещей, это было бы такой же бессмыслицей.

Михаил ЛОМОНОСОВ

\section{КОГНИТИВНЫЙ ИНСТРУМЕНТАРИЙ ИССЛЕДОВАНИЯ МЕЖРЕГИОНАЛЬНОЙ ЭКОНОМИЧЕСКОЙ ИНТЕГРАЦИИ}

Введение. В современных условиях исследование межрегиональной интеграции, охватывающей экономическое, технологическое, ресурсное, финансовое, информационное и другие виды взаимодействия между двумя или несколькими региональными субъектами, представляет собой актуальную народно-хозяйственную задачу. Регулирование интеграционных процессов регионов предполагает достижение оптимального баланса их экономических интересов с учетом системности действий и использования конкурентных преимуществ. Взаимовыгодные рыночно-партнерские отношения, формирующие торгово-экономические связи и товарно-финансовые потоки между регионами, являются интегрирующей базой совершенствования регионального экономического пространства. Исследованию проблем и разных аспектов межрегиональной интеграции посвящено много трудов как зарубежных, так и российских авторов. Перечисление их работ может занять не одну страницу, сошлемся здесь только на [1-5], имеющие непосредственное отношение к исследованиям. Добавим, что для целей наших исследований особый интерес представляли работы, посвященные специфике эволюции российских интеграционно-экономических отношений на разных этапах развития с учетом институциональных особенностей российской экономики, роли экономического пространства в межрегиональной интеграции, рыночной теории международных, межрегиональных и внутрирегиональных торгово-экономических отношений.

Все вышеобозначенные направления исследований межрегиональной интеграции в определяющей степени направленны на сам объект исследования, на разнообразные аспекты проблемы, процессы и механизмы межрегиональных отношений, на участников интеграции и др., а не на разработку специальных методов исследования сложной системы взаимодействия и интеграции регионов, что необходимо для обоснования принимаемых на разных уровнях управленческих решений для их совершенствования.

\footnotetext{
${ }^{1}$ Инженерно-технологическая академия Южного федерального университета, 347922, г. Таганрог, Россия 2 Донской государственный технический университет (ДГТУ), 344065, г. Ростов-на-Дону, Россия, borisovalv09@mail.ru
}

${ }^{1}$ Горелова Г. В., 'Борисова Д. В. *

УДK: 338.2

DOI: 10.21177/1998-4502-201911-1-65-78

Представлен когнитивный инструментально-методический апnарат, предназначенный для исследования сложных систем (социально-экономических, экологических, социотехнических и т.n.). Этот инструментарий является совокупностью математических и программных средств. Он позволяет исследовать сложные системы путем имитационного когнитивного моделирования их структуры и поведения. Инструментарий адаптирован для решения задач исследования межрегиональной экономической интеграции и дополнен методами нечеткого моделирования. Приведено несколько результатов когнитивного исследования, проведенного для обоснования и принятия решений по совершенствованию управления процессами интеграции.

\section{КЛЮЧЕВЫЕ СЛОВА:}

межрегиональная экономическая интеграция, исследование, имитационное моделирование, когнитивная модель, сценарный анализ, устойчивость.

Статья поступила в редакцию 03.10.2018. 
При выполнении исследовательской работы по изучению межрегиональной экономической интеграции именно этому вопросу было уделено основное внимание. Была поставлена цель выбора подхода к исследованию проблем интеграции, адаптации существующего или разработки нового инструментария для решения задач совершенствования процессов интеграции. Были использованы идеи теории систем и системного анализа [6] и имитационного моделирования [7; 8], поскольку реальный эксперимент над сложной системой межрегиональной экономической интеграции для получения большинства необходимых данных трудно допустить. Среди методов имитационного моделирования был выбрано когнитивное моделирование [9-16], развиваемое с середины прошлого века. В России подобные исследования начались в 90-х годах прошлого столетия $[11 ; 12 ; 14 ; 15]$.

Задачей настоящей работы было представление когнитивного инструментария исследования сложных систем, адаптированного к условиям межрегиональной экономической интеграции, а также некоторые результатов когнитивного моделирования межрегиональной экономической интеграции на Юге России.

Материал и методы исследования. Анализ процессов межрегиональной экономической интеграции, оценка ее уровня и перспектив развития оказались возможными с помощью разработанного когнитивного инструментально-методического аппарата, представляющего собой систему программных и математических средств четкого [17-24] и нечеткого [25-34] когнитивного моделирования, сценарного анализа, позволяющего спрогнозировать различные альтернативы развития сложной социально-экономической системы. Эти методы и подходы позволяют формализовать и объяснить структуру и поведение исследуемой системы, а также сделать обоснованный выбор наиболее эффективного решения в сфере совершенствования управления процессами межрегиональной интеграции. Применение инструментария позволяет учитывать качественную природу и количественную определенность информационно-аналитической базы при описании факторных и результативных признаков исследуемой системы. Основным теоретическим отличием разработанного инструментария от существующего стало добавление в него методов определения индекса интенсивности товарооборота, определения структурных сдвигов на товарных рынках, интегрального индикатора уровня развития интеграции, оценки уровня межрегиональной интеграции на основе аппарата теории нечетких множеств [25-27],

Анализ социально-экономических показателей регионов ЮФО и характеристик межрегиональной экономический интеграции между ними обозначил необходимость: во-первых, учитывать многокритериальность задачи оценки социально-экономического развития регионов ЮФО, во-вторых, разработать ин- тегральный индикатор эффективности межрегиональной экономический интеграции, который позволял бы определять уровень развития регионов с учетом множества разнонаправленных и разноразмерных показателей, в-третьих, оценивать риски интеграционных процессов регионов и структурные сдвиги на товарных рынках.

Для характеристики уровня межрегиональной интеграции были выбраны основные группы входных признаков: 12 социально-экономических показателей, 7 показателей уровня транспортного сообщения, 4 показателя уровня развития связи и величина товарооборота. Эти данные стали основой при формализации и логико-лингвистическом описании входных признаков по группе «социально-экономические показатели» при разработке нечетких экономико-математических моделей и реализации механизма нечеткого логического вывода при определении уровня межрегиональной интеграции.

Для адекватного формализованного представления информации, не поддающейся количественному измерению, а имеющую качественную природу, в работе было произведено лингвистическое описание и моделирование основных групп входных факторов, характеризующих уровень межрегиональной интеграции. Выполнена оценка согласованности нечетких экспертных знаний. В процессе исследования были разработаны нечеткие 3-термовые экономико-математические модели для группы социально-экономических факторов, товарооборота; уровня транспортного сообщения, уровня развития связи; 5-термовой модели для выходного признака «уровень межрегиональной интеграции» с термами (низкий, ниже среднего, средний, выше среднего, высокий).

Для определения значения уровня межрегиональной интеграции Ростовской области с регионами-партнерами Юга России была применена методика дефаззификации на основе нечеткого логического вывода [30-32]. Модель уровня межрегиональной интеграции процессов показывает, на какой ступени развития находятся интеграционные экономические связи между регионами-партнерами, степень их развития и интенсивности. Реализация процедуры нечеткого логического вывода позволила адекватно оценить уровень трансрегиональных экономических связей Ростовской области с другими регионами ЮФО.

Полученные результаты, методы, разработанные для их получения, позволили предложить схему когнитивного моделирования сложной системы межрегиональной экономической интеграции (рис. 1, 2), которая может быть использована для исследований интеграции разных регионов.

Дадим ряд пояснений к данной схеме. Методы когнитивного моделирования последние десятилетия стали активно развиваться наряду с другими подходами и методами моделирования сложных систем в различ- 
ных областях, в том числе в сфере экологии, экономики, социальной и технической.

В начале 2000-х годов когнитивное моделирование сложных систем [17-19; 24; 33] базировалось на исследованиях ИПУ РАН, Москва $[11 ; 12 ; 14 ; 15]$. Дальнейшее развитие этого направления получило в Инженерно-технической академии Южного федерального университета, г. Таганрог [17-24]. Основное отличие от начальных работ ИПУ состоит в разработанных методологии и программном продукте, которые расширили возможности когнитивных исследований сложных систем разной природы. В рамках исследований под когнитивным моделированием и когнитивной методологией понимается следующее.

Когнитивная методология является системой методов решения последовательности задач, позволяющих идентифицировать объект в окружающей среде (в виде когнитивных моделей), проводить анализ путей и циклов когнитивной модели для понимания свойств устойчивости системы и способов достижения цели, проводить анализ различных аспектов сложности и связности системы, с помощью импульсного моделирования разрабатывать возможные сценарии развития системы, обосновывать управленческие решения в условиях информационной и другой неопределенности, сопутствующей существованию и изучению сложной системы. Процесс исследования и принятия решений многоэтапный и циклический, поэтому объекты начальной когнитивной модели могут видоизменяться.

Для того чтобы организовать процесс когнитивного моделирования, необходимо следовать определенной программе. Эта программа задается метамоделью исследования [21, с. 91-92]:

$$
\text { « } M=\left\{M_{O}, M_{E}, M_{O E}, M_{D^{\prime}} M_{M O^{\prime}} M_{M E}, Q, M_{U}, M_{H^{P}} A\right\},
$$

где $M_{O}$ (идентифицирующая модель сложной системы), $M_{E}$ (модель окружающей среды) и $M o_{E}$ (модель взаимодействия объекта и среды) являются когнитивными моделями; $M_{D}$ - модель поведения системы (сценарий, импульсный процесс); $M_{M O}$ и $M_{M E}-$ модели измерения состояния системы и окружающей среды; $Q$ - возмущающие воздействия; $M_{U}-$ модель управляющей системы; $M н$ - модель «наблюдателя» (инженера-когнитиолога, эксперта, исследователя); $A$ - правила объединений моделей и выбора процессов изменения объекта. Модель $M н$ (наблюдателя, исследователя, лица, принимающего решения) проявляется в процессе всего когнитивного моделирования, который отражает процесс познания субъектом изучаемого объекта».

Когнитивная карта (модель) отображает причинноследственные связи в сложной системе [9; 13; 16].

Математически когнитивная карта имеет вид знакового ориентированного графа

$$
G=\langle V, E\rangle,
$$

«... где $V=\left\{v_{i}\right\}, i=1,2, \ldots, k-$ множество вершин (концептов) когнитивной карты, являющихся элементами изучаемой системы; $E=\left\{e_{i j}\right\}-$ множество дуг, соединяющих вершины $v_{i}$ и $v_{j}, i, j=1,2, \ldots, k$; $e_{i j}$ фиксирует причинно-следственную связь между вершинами $v_{i}$ и $v_{j}$. Влияние вершины $v_{i}$ на $v_{j}$ в изучаемой ситуации может быть положительным, когда увеличение (уменьшение) одного фактора приводит к увеличению (уменьшению) другого, отрицательным, когда увеличение (уменьшение) одного фактора приводит к уменьшению (увеличению) другого, или отсутствовать в конкретной ситуации» [17; 21, с.93] .

Модель системы в виде начальной (стартовой) когнитивной карты $G_{1}$ может в процессе исследования последовательно преобразовываться в более сложную математически и по содержанию когнитивную модель, например, в параметрический векторный функциональный граф $\Phi_{\Pi}[11 ; 15 ; 17]$. В такой модели отношения между вершинами могут иметь вес или задаваться в виде функции.

В реальных сложных системах может быть много нечеткой информации, что требует ее представления в виде нечеткой когнитивной карты:

$$
G_{i \div}=\langle V, W\rangle,
$$

где $V$ имеет тот же смысл множества вершин, $v_{i} \in V, i=1,2, \ldots h, W$ - нечеткие причинно-следственные связи между вершинами: $w_{i j} \in W$ определяются тем или иным типом функции принадлежности.

Когнитивное моделирование сложных систем происходит поэтапно. На рис.1 и рис.2 (Fig.1 and Fig.2) изображена схема этапов моделирования межрегиональной экономической интеграции, которая построена в соответствии с общей схемой методологии когнитивного моделирования [17]. Схема исследования адаптирована к условиям межрегиональной интеграции.

На рис. 3-8 (Fig. 3-8) приведены некоторые результаты когнитивного моделирования межрегионального экономического взаимодействия.

Эman I. Разработка когнитивной картыл. В результате выполнения первого этапа моделирования была разработана когнитивная карта, изображенная на рис.4. Ее вершины и отношения между ними были установлены в результате анализа теоретических сведений о межрегиональных взаимодействиях, статистических данных по регионам, экспертным опросам. 
Pre-project stage: collection of information, determination of the nature and development trends of the system of interregional economic integration, systematization of theoretical conceptual positions, analysis of the main properties and characteristics of the system, formulation and clarification of the research objectives

Definition Metamodel elements: the object model $M_{O}$, the environment $M_{E}$ and their connections $M_{O E}$; object measurement models $M_{M O}$ and the environment $M_{M E}$; models of dynamics $M_{D}$ perturbation $Q$; management models $M_{U}$

Stage I. Designing of the cognitive model "Interregional Economic Integration" $G=\left\{M_{O}, M_{E}, M_{O E}\right\}$; definition of vertices, relations between them, weights, functional dependencies

1.1. Determination and justification of the choice of vertices of the cognitive model $G$; building the table of vertices

1.2. Definition and justification of the choice of connections between the vertices of the cognitive model $G$; creating a table of relations

1.2.1. Determination of the fact of the relationship of the RO with the regions of the Southern Federal District based on the analysis of the dynamics of the volumes of cross-border trade between the regions, determination of the turnover intensity index

1.2.2. Determination of structural changes in the commodity markets of the regions of the Southern Federal District based on the index method

1.2.3. Analysis of the calculation of the amplitude of fluctuations in the GRP of the regions of the Southern Federal District to identify the prerequisites for the process of interregional integration in southern Russia

1.3. Evaluation of the effectiveness of interregional economic integration

1.3.1. Definition of an integral indicator of the level of integration

1.3.2. Assessment of the level of interregional integration based on the apparatus of the theory of fuzzy sets

Go to stage II

Pис. 1. Схема методики когнитивного моделирования системы межрегиональной экономической интеграции, начальные этапь

Fig. 1. The scheme of cognitive modeling techniques systems of interregional economic integration, the initial stages 


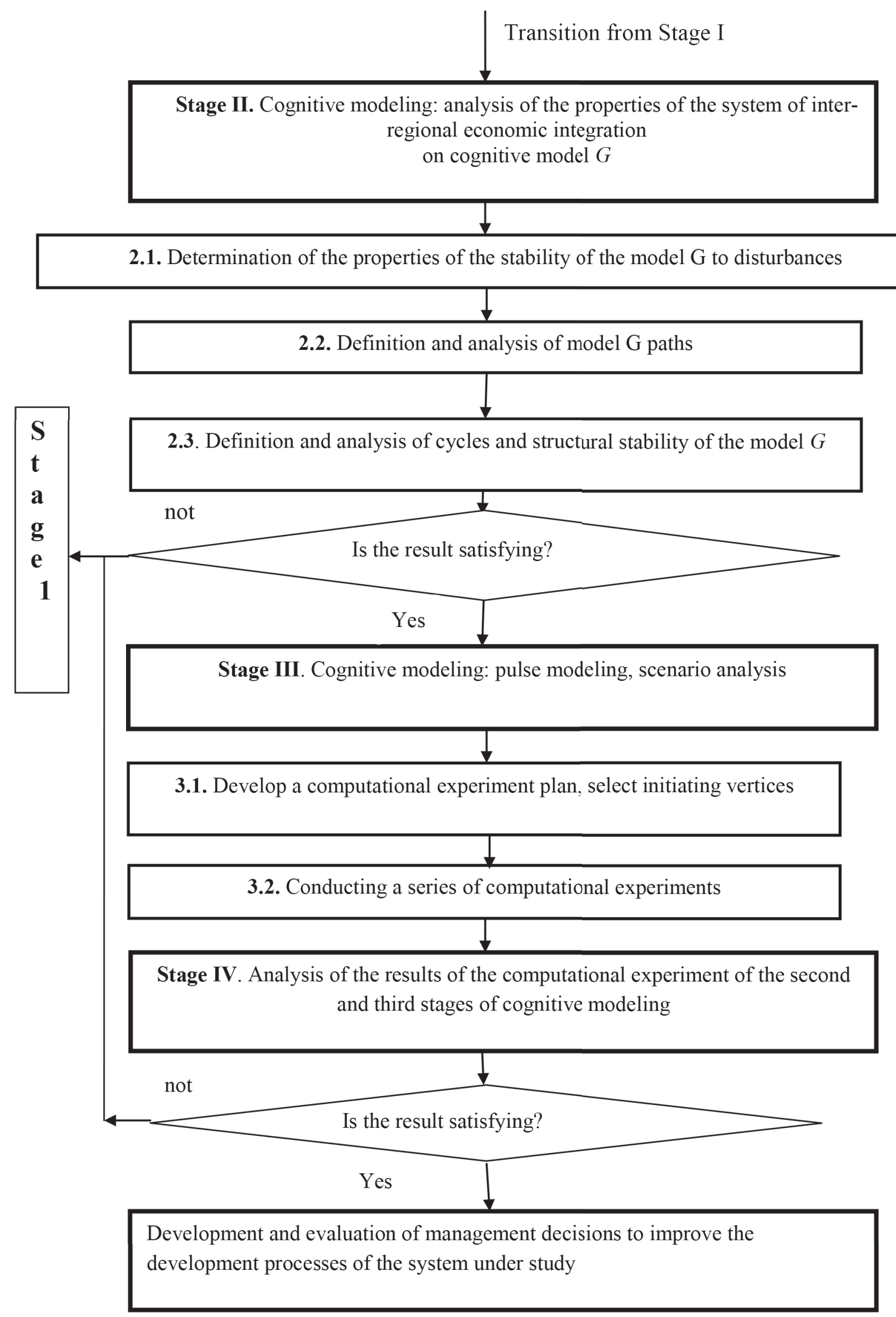

Pис. 2. Схема методики когнитивного моделирования системы межрегиональной экономической интеграции, конечные этапь

Fig. 2. Continuation of the cognitive modeling methodology systems of interregional economic integration, the final stages 
В качестве множества $V=\{v i\}$ основных вершин для «стартовой» когнитивной карты G1 были выбраны и обоснованы следующие:

$V 1$ - ВРП региона, $V 2$ - межрегиональная экономическая интеграция, $V 3$ - социально-экономическое состояние региона, $V 4$ - население региона, $V 5$ - миграция, $V 6$ - структура производства, $V 7$ - субъекты экономических отношений на макроуровне (регионы), $V 8$ - социально-экономическая дифференциация регионов, $V 9$ - ресурсный потенциал региона, $V 10$ - рыночная инфраструктура, $V 11$ - товарооборот, $V 12$ - политика капиталовложений, $V 13$ - уровень транспортного сообщения, $V 14$ - уровень развития и состояния связи, интернет, информационное взаимодействие, $V 15$ - межрегиональная конкуренция, $V 16$ - инновационно-инвестиционные процессы, $V 17$ - единое ценовое поле, $V 18$-политическая ситуация, $V 19$ - риски, $V 20$ - региональные органы власти, $V 21$ - политика государства, $V 22$ - система правовых норм.

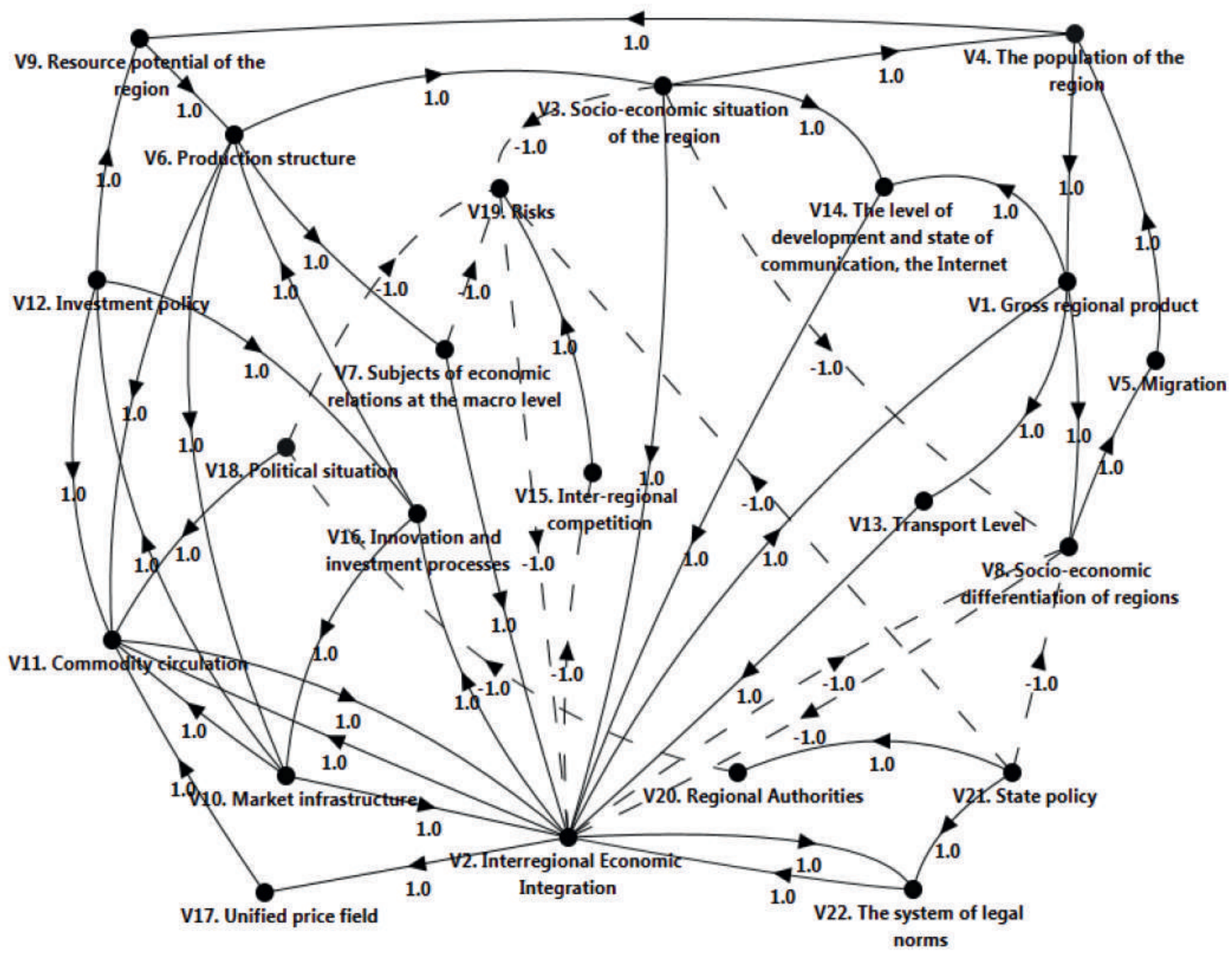

Pис. 3. Когнитивная карта G1 «Межрегиональная экономическая интеграция»

Fig. 3. Cognitive map G1 «Interregional economic integration»

V1 - Gross regional product, V2 - Interregional Economic Integration, V3 - Socio-economic situation of the region, V4 - The population of the region, V5-Migration, V6-Production structure, V7-Subjects of economic relations at the macro level, V8Socio-economic differentiation of regions, V9-Resource potential of the region, V10 - Market infrastructure, V11 - Commodity turnover, V12 - Investment policy, V13-Transport Level, V14-The level of development and state of communication, the Internet, V15 - Inter-regional competition, V16 - Innovation and investment processes, V17 - Unified price field, V18 - Political situation, V19-Risks, V20 - Regional Authorities, V21 - State policy, V22 - The system of legal norms. 
Этап II. Когнитивное моделирование. Анализ свойств когнитивной карты:

1. Устойчивость к возмущениям. Поскольку максимальный по модулю корень характеристического уравнения матрицы отношений модели $G_{1}|\mathrm{M}|=2,4735>1$, то это свидетельствует о неустойчивости к возмущению и по начальному значению. Система не устойчива.

2. Анализ циклов когнитивной карты и структурной устойчивости.

На рис.4 (Fig.4) и рис.5 (Fig.5) представлены 2 цикла: $V 1 \rightarrow V 13 \rightarrow V 2 \rightarrow \ldots V 5 \rightarrow V 4 \rightarrow V 1$, отрицательный стабилизирующий процессы, и положительный $V 1 \rightarrow V 8 \rightarrow V 5 \rightarrow V 4 \ldots \rightarrow \ldots V 1 \rightarrow 1 V 2 \rightarrow V 1$ (отсутствуют отрицательные дуги или имеется их нечетное число), это цикл - акселератор процессов в системе. Анализ характера циклов (всего их в этой системе 64) позволяет анализировать непротиворечивость разработанной модели по отношению к реальной системе, интерпретировать результаты и, главное, исследовать свойства устойчивости.

Анализ структурной устойчивости. Согласно условию, характеризующему структурную устойчивость $[13 ; 16 ; 21]:$ если в модели имеется нечетное число отрицательных циклов - модель структурно устойчива. В данном случае наблюдается свойство структурной устойчивости: среди 64 циклов имеется 19 отрицательных.

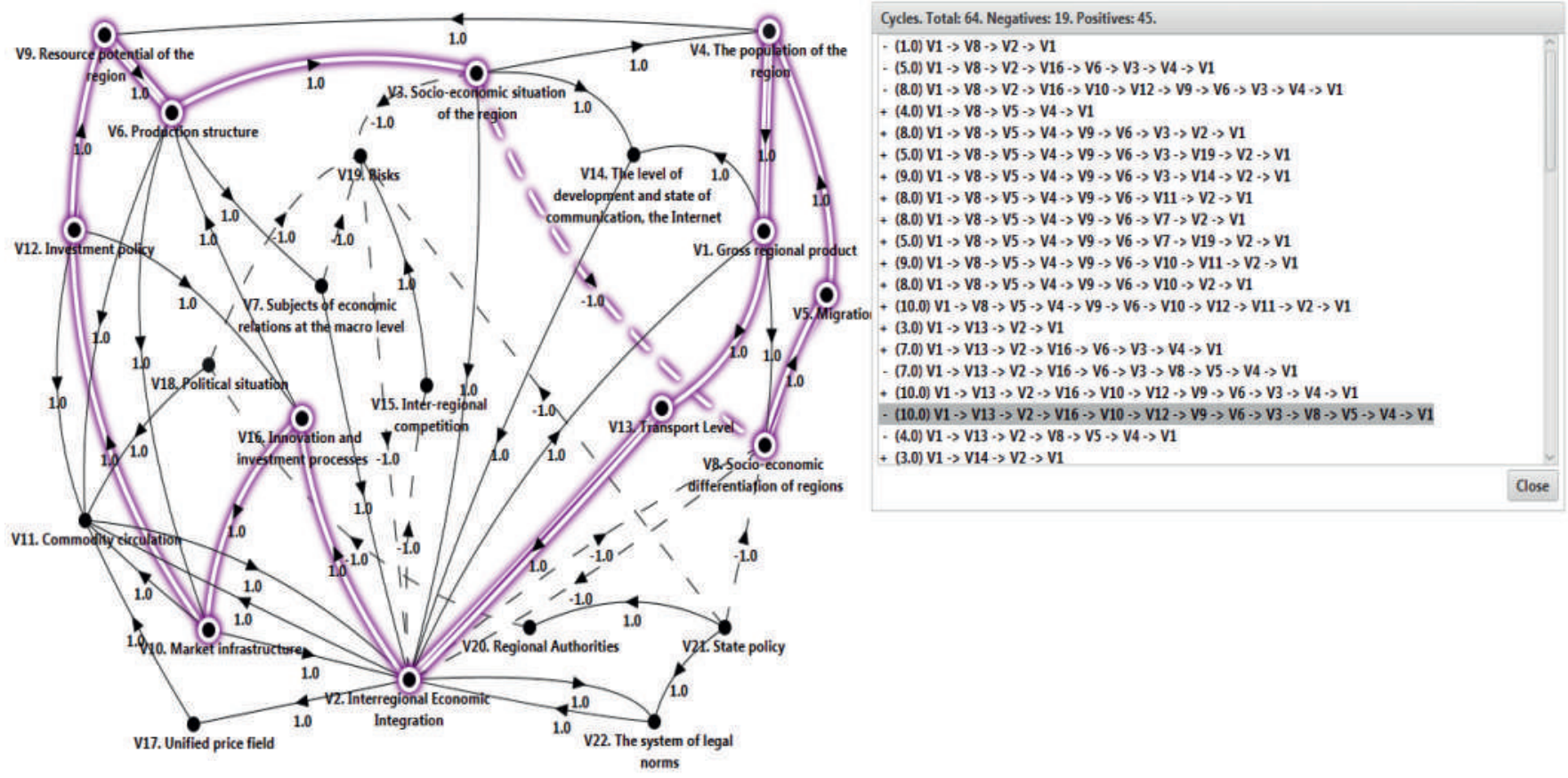

Pис. 4. Цикл отрицательной обратной связи

Fig. 4. Negative feedback loop
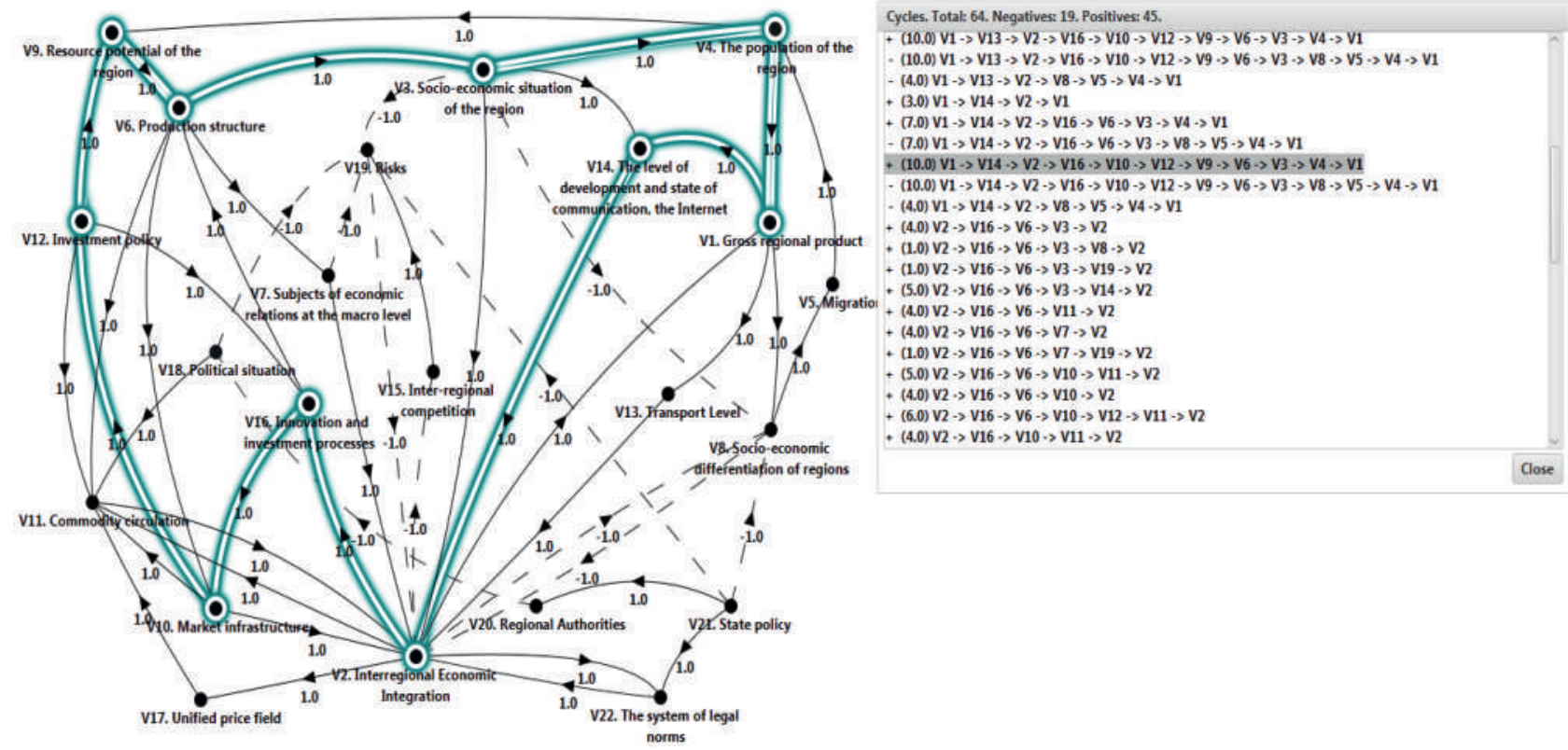

Pис. 5. Цикл положительной обратной связи

Fig. 5. Positive feedback loop 
3. Анализ путей когнитивной карты. На рис.6 (Fig.6) показаны варианты путей из вершины V11 «Товарооборот» в вершину $V 3$ «СЭС», т.е. анализируются возможные варианты влияния товарооборота на СЭС. Имеется 4 варианта, на рис.6 выделен «положительный путь», т.е. в нем нет отрицательных дуг. Выделение разных путей на карте позволяет: осмысливать правильно или неправильно определены причинно-следственные цепочки исследуемой сложной системы, интерпретировать их смысл, использовать далее для обоснования принимаемых решений.
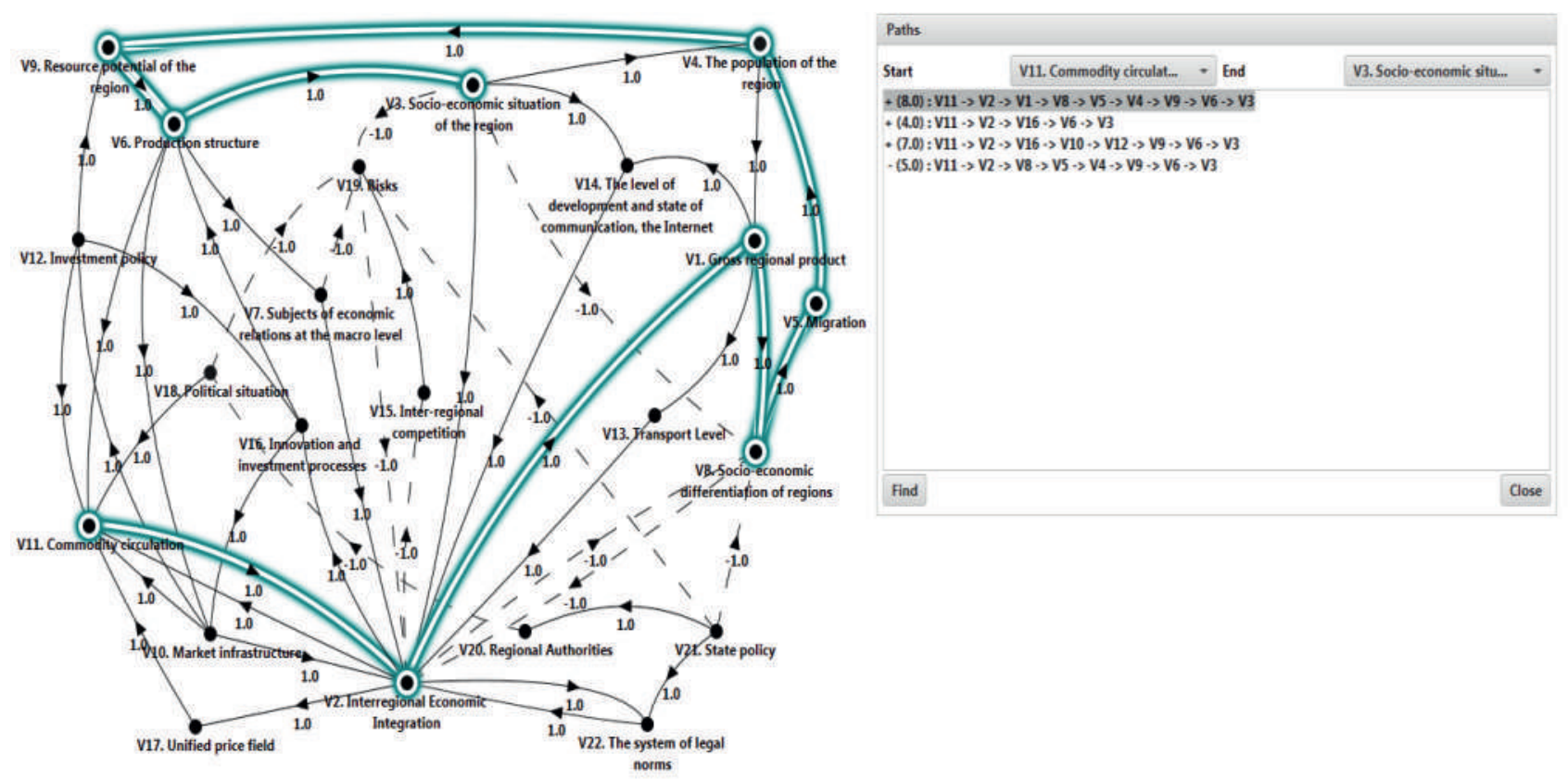

Pис. 6. Путь от вериины V11 до вериины V3, влияние товарооборота на соичально-экономическую ситуаџию в регионе

Fig. 6. The path from vertex V11 to vertex V3, the impact of commodity turnover on the socio-economic situation in the region

Этап III. Импульсное моделирование, сиенарный анализ. Сценарный анализ предназначен для предвидения возможных тенденций развития ситуаций на модели. Производится путем импульсного моделирования [15]. Приведем результаты импульсного моделирования по двум более простым сценариям (внесение возмущения $q_{i}$ в одну из вершин $V_{i}$ ).

Сценарий №1. Пусть наблюдается рост ВРП региона, вносимый импульс: $q_{1}=+1$ (остальные вершины не инициируются); вектор возмущений: $Q_{1}=\left\{q_{1}=+1 ; q_{2}=0 ; \ldots ; q_{22}=0\right\}$.

Сценарий №2. Пусть наблюдается рост (укрепление) межрегиональной экономической интеграции, вносимый импульс: $q_{2}=+1$; вектор возмущений: $Q_{2}=\left\{q_{1}=0 ; q_{2}=+1 ; q_{3}=0 ; \ldots q_{22}=0\right\}$.

На рис.7 (Fig.7) и рис. 8 (Fig.8) изображены графики импульсных процессов, построенные по результатам вычислительного эксперимента. Поскольку визуальный анализ изображения сразу во всех вершинах затруднителен, изображения были разбиты на несколько групп импульсных процессов. На рисунках представлены 2 группы.

Помимо представленных результатов моделирования двух сценариев в исследовании было проведено несколько серий вычислительного эксперимента при комбинации вносимых возмущений в две, три, четыре и более вершин когнитивной карты. Но основные возможные тенденции развития ситуаций достаточно хорошо проявляются и в приведенных сценариях. Другие сценарии показывают изменения численных значений импульсов в вершинах модели, скорость протекания процессов и дают возможность лицу, принимающему решения, сопоставляя результаты, выбирать лучший сценарий, но иметь в виду и возможность худших.

Полученные результаты и их обсуждение. Проанализируем все приведенные выше результаты когнитивного моделирования. Рассмотрим сначала сценарии.

Как видно по рис.7 (Fig.7), возможность роста ВВП (тонкая сплошная линия на левом изображении; заметим, в данном предположении мы пока не рассматриваем вопрос, за счет чего может произойти рост) приводит к появлению положительных тенденций развития ситуаций во всех вершинах когнитивной карты. Например, растут межрегиональная интеграция, товарооборот, уровень транспортных и информационных связей, снижаются риски и дифференциация регионов (также можно описать все графики). На рис.7 изображены результаты 7 шагов моделирования, но вычислительный эксперимент при увеличении шагов показал сохранение обозначенных тенденций. Сопоставляя графики импульсных процессов двух сценариев, видим, что 

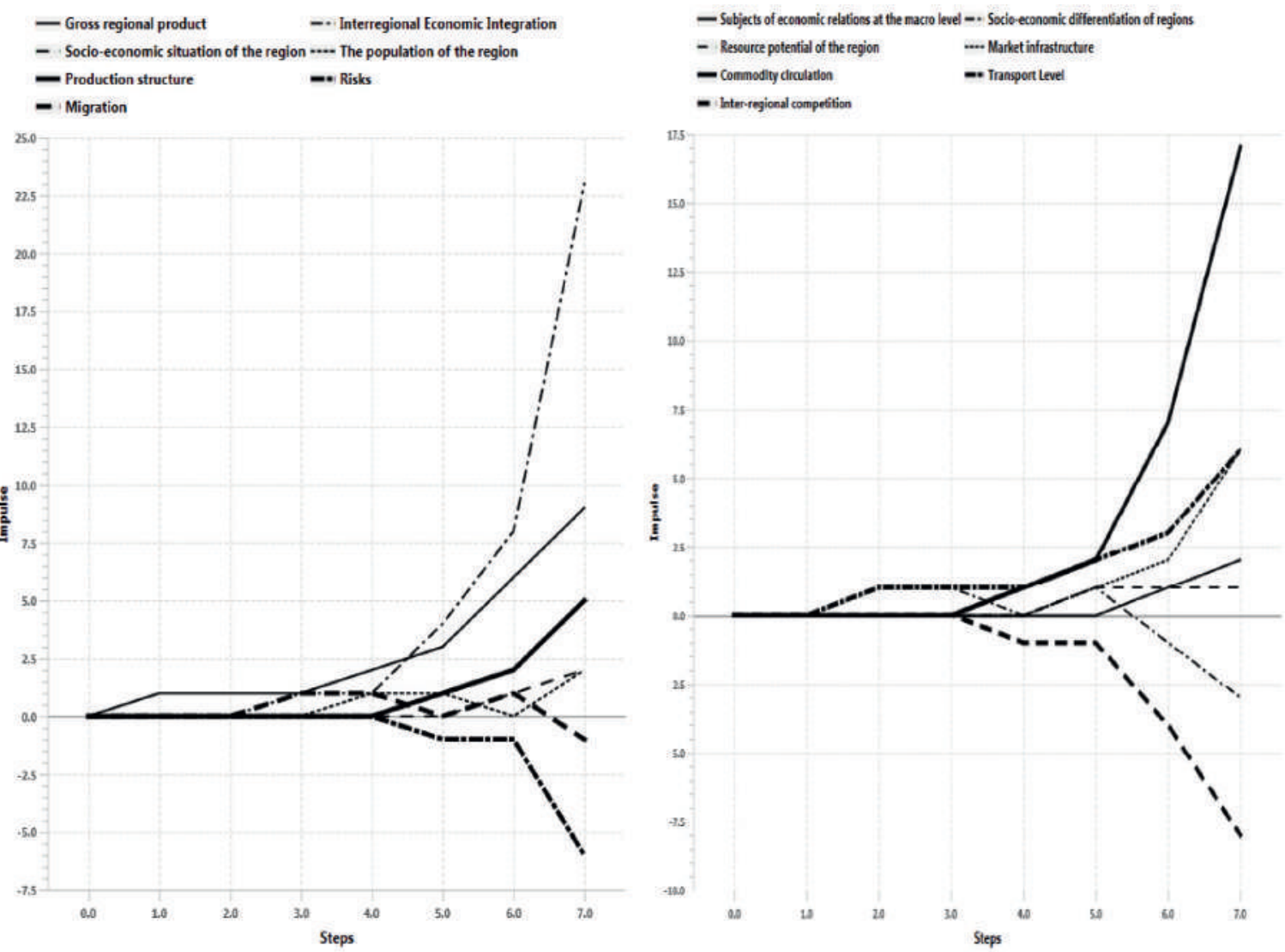

Pис. 7. Графики импульсных процессов, соответствующие сценарию N1

Fig. 7. Charts of impulse processes, corresponding to the scenario N1
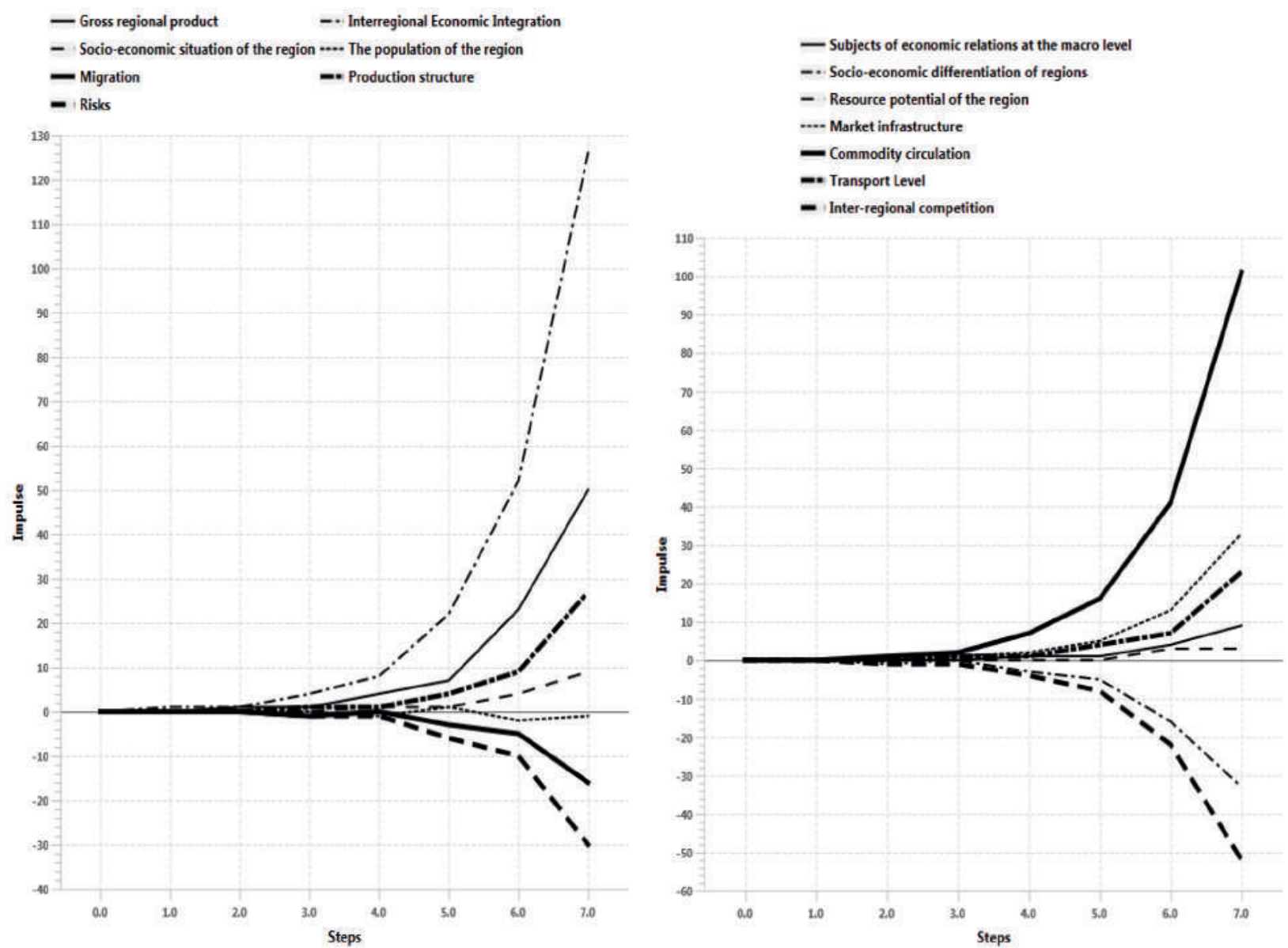

Pис. 8. Графики импульсных процеессов, соответствующие сиенарию N2

Fig. 8. Charts of impulse processes, corresponding to the scenario N2 
выводы о тенденциях процессов, полученные после анализа результатов сценарного моделирования по Сценарию №1 можно повторить и для Сценария №2. Инициирование $\left(q_{2}=+1\right)$ вершины $V 2$ (Межрегиональная экономическая интеграция) на данной структуре G1 приводит к дальнейшему положительному изменению (росту) межрегиональной экономической интеграции и ВРП. Наблюдаемые в двух этих случаях тенденции свидетельствуют, в том числе, о не противоречии реальности разработанной когнитивной карты, т.е. обобщающей гипотезы о том, что рост ВРП и межрегиональной интеграции может улучшить социально-экономическое состояние региона. Сравнение результатов моделирования по двум сценариям показывает, что рост ВРП за счет развития межрегиональной экономической интеграции может быть значительнее, чем по каким-либо другим причинам (как в Сценарии №1). Так, на 7 такте моделирования величины импульсов в вершинах $V 1$ и $V 2$ достигают значений по Сценарию №1: 9,0 и 23 соответственно, а по Сценарию №2: 50 и 126 соответственно. То же можно сказать и по остальным вершинам. Отсюда можно начинать делать вывод, что развитие межрегиональной экономической интеграции эффективно для регионов при наличии концептов, отображенных в когнитивной карте, как факторов интеграции.

Сопоставляя результаты импульсного моделирования с результатами анализа устойчивости, видим, что факт неустойчивости к возмущениям подтверждается тенденциями «наращивания» процессов, отсутствием их стабилизации на некотором уровне. Но структурная устойчивость системы говорит о том, что характер процессов не изменяется, будут меняться пропорции.

Заключение. В работе представлены разработанный когнитивный инструментарий и результаты когнитивного моделирования сложной системы межрегиональной экономической интеграции, полученные с его помощью. Представлена схема этапов когнитивного моделирования, которая адаптирует и дополняет существующие схемы когнитивного моделирования сложных систем методами обработки нечетких данных, расчетом интегрального показателя эффективности межрегиональной интеграции, оценкой рисков интеграционных процессов. Приведены примеры выполнения большинства этапов когнитивно- го моделирования межрегиональной экономической интеграции. Выполнение первого этапа когнитивного моделирования для обоснования выбора вершин и отношений между ними потребовало, помимо теоретических изысканий, провести сбор, анализ и обработку статистической и экспертной информации, в том числе, по регионам ЮФО. Наличие количественных и качественных факторов, от которых зависит возможность и эффективность межрегиональной экономической интеграции, сделала необходимым использование методов теории четких и нечетких множеств и соответствующей логики для обоснования выбора вершин и фактов их взаимосвязи.

Таким образом, специфика межрегиональной экономической интеграции, как сложной системы, определила необходимость привлечения разнообразных методов исследования и сведения их в единую когнитивную систему, объединенную последовательностью процессов познания.

Использование когнитивного подхода к исследованию сложных социально-экономических систем и применение в этих целях специального инструментария позволяет видеть всю сложную систему в целом, не теряя детали, и повышать тем самым обоснованность и системность управленческих решений, целью которых чаще всего является повышение эффективности функционирования системы. Разработанную схему когнитивного моделирования межрегиональной экономической интеграции и соответствующий инструментарий можно рекомендовать к использованию в исследованиях разных регионов страны.

Дальнейшие исследования возможны как в теоретическом направлении, в расширении возможностей схемы когнитивного моделирования путем включения в неё новых методов обработки информации, методов когнитивного анализа на втором этапе моделирования, так и в практическом - исследуя различные процессы межрегиональной интеграции.

Добавим, что когнитивные исследования сложных систем принадлежат к направлению «Искусственный интеллект» в составе когнитивных наук. Инструментарий когнитивного моделирования сложных систем можно использовать при создании интеллектуальных систем поддержки принятия решений.

\section{КРИТЕРИИ АВТОРСТВА / Contribution:}

Горелова Г.В. разработала инструментарий когнитивного моделирования, участвовала в проведении когнитивного моделирования, написала рукопись и несет ответственность за плагиат; Борисова Д.В. собрала необходимый материал, разработала модели нечеткого моделирования, участвовала в проведении когнитивного моделирования / Gorelova G. $\boldsymbol{V}$. has developed a tool of cognitive modeling, participated in the cognitive modelling, wrote the manuscript and is responsible for plagiarism; Borisova D. V. have gathered the necessary material, has developed a model of fuzzy modeling, participated in the cognitive modeling. 


\section{КОНФЛИКТ ИНТЕРЕСОВ / Conflict of interest}

Авторы заявляют об отсутствии конфликта интересов / The authors declare no conflict of interest.

\section{ЛИТЕРАТУРА:}

1. Полякова А.Г., Герасимова В.В. Теоретические аспекты изучения региональной экономической интеграции и социально-экономического пространства региона // Интеллект. Инновации. Инвестиции. 2010. ⒉ С.50-56.

2. Жукова Т. В. Борисова Д. В. Межрегиональная экономическая интеграция как инструмент социо-хозяйственного развития // Экономика и предпринимательство. 2017. N. Ч.1 С. 255-258.

3. Стецко Н. И. Неравномерность экономического развития регионов в теориях пространственной организации экономических систем // Фундаментальные исследования. 2017. N6. C. $185-189$.

4. Ахунов Р. Р. Развитие межрегиональной интеграции как направление повышения конкурентоспособности в системе воспроизводственного потенциала региона // Вестник УГУЭС. Наука, образование, экономика. Серия экономика. 2016. N1 (15). С. 7-16.

5. Моделирование и управление процессами регионального развития / Под ред. С. Н. Васильева. М.: Физматлит, 2001. $432 \mathrm{c}$.

6. Волкова В. Н., Денисов А. А. Основы теории систем и системного анализа. СПб.: Изд. СПбГПУ, 2005. 520 с.

7. Каталевский А. Ю. Основы имитационного моделирования и системного анализа в управлении. М.: Изд-во МГУ, 2011. 304 с.

8. Масленникова А. В. Динамическая модель межрегионального развития РФ для исследования стратегий управления социально-эколого-экономическими региональными процессами // Управление развитием крупномасштабных систем (MLSD'2010): Труды Четвертой международной конференции 14, 15. М.: ИПУ РАН им. В.А.Трапезникова, 2010. T. 2. C. 346-352.

9. Axelrod R. The Structure of Decision: Cognitive Maps of Political Elites. Princeton. University Press. 1976.

10. Atkin R. H. Combinatorial Connectivies in Social Systems. An Application of Simplicial Complex Structures to the Study of Large Organisations. Interdisciplinary Systems Research. 1997, 245 p.

11. Абрамова Н. А., Воронина Т. А., Порцев Р. Ю. О методах поддержки, построения и верификации когнитивных карт с применением идей когнитивной графики // Управление большими системами. М.: ИПУ РАН, 2010. Специальный выпуск 30.1. С. 411-430.

12. Авдеева 3. К. Эвристический метод концептуальной структуризации знаний при формализации слабоструктурированных ситуаций на основе когнитивных карт // Управление большими системами. М.: ИПУ РАН, 2010. Выпуск 31. N3. C. 6-34.

13. Casti J. Connectivity, complexity and catastrophe in largescale systems. Chichester-New York-Brisbane-Toronto. 1979. 216 p.

14. Коврига С. В., Максимов В. И. Когнитивная технология стратегического управления развитием сложных социально-экономических объектов в нестабильной внешней среде // Сборник трудов международной конференции «Когнитивный анализ и управление ситуациями» (CASC'2001), 2001. T.1
15. Кульба В. В., Кононов Д. А., Ковалевский С. С., Косяченко С. А, Нижегородцев Р. М., Чернов И. В. Сценарный анализ динамики поведения социально-экономических систем. М.: ИПУ РАН, 2002. 122 с.

16. Робертс Ф. С. Дискретные математические модели с приложениями к социальным, биологическим и экологическим задачам. Пер. с англ. А. М. Раппопорта, С. И. Травкина. Под ред. А. И. Теймана. М.: Наука, 1986. 496 с.

17. Горелова Г. В., Захарова Е. Н., Радченко С.А. Исследование слабоструктурированных проблем социально-экономических систем: когнитивный подход. Ростов-на-Дону: Изд-во РГУ, 2006. 332 с.

18. Ginis L. A., Gorelova G. V., Kolodenkova A. E. Cognitive and simulation modeling of Socioeconomic systems / Proceedings of the International Research Conference Information Technologies in Science, Management, Social Sphere and Medicine (ITSMSSM 2017), 2017, vol. 72, pp. 50-54

19. Gorelova G. V., Pankratova N. D. Scientific Foresight and Cognitive Modeling of Socio-Economic Systems / IFAC Proceedings Volumes, $18^{\text {th }}$ IFAC Conference on Technology, Culture and International Stability TECIS. 2018. pp. 145-149.

20. Захарова Е. Н., Панкратова Н. Д. К вопросу о возможности разработки и анализа стратегий и программ развития территорий с помощью когнитивного имитационного моделирования // Вестник АГУ. 2015. N4 (170). С. 182-195.

21. Инновационное развитие социо-экономических систем на основе методологий предвидения и когнитивного моделирования / Под ред. Г. В. Гореловой, Н. Д. Панкратовой. Киев: Наукова Думка, 2015. 464 с.

22. Исмиханов 3. Н. Моделирование социально-экономического развития региона на основе когнитивного подхода (на примере республики Дагестан) // Бизнес-информатика. 2015. N2 (32). С. 59-68

23. Ismihanov Z. N., Omarova N. O., Aripova P. G., Umargadzhieva N. M., Magomedov M. S. Structuring knowledge and cognitive map for scenario forecasting of the situation development in the region // Espacios. 2017. vol. 38. N33. C. 7.

24. Программа для когнитивного моделирования и анализа социально-экономических систем регионального уровня. Свидетельство о государственной регистрации программ для ЭВМ N 2018661506 от 07.09.2018.

25. Kosko B. Fuzzy Cognitive Maps // Intern. Journal of Man-Machine Studies. 1986. vol. 24. pp. 65-75.

26. Kosko B. Fuzzy Thinking: The New Science of Fuzzy Logic. Hyperion. Disney Books, 1993. 336 p.

27. Zadeh L. A. Knowledge representation in fuzzy logic. An Introduction to Fuzzy Logic Applications in Intelligent Systems / In: The Springer International Series in Engineering and Computer Science. Boston, Springer, 1992, vol. 165, pp. 1-27. DOI: 10.1007/978-1-4615-3640-61254.

28. Dimitrov V. P., Borisova L. V., Nurutdinova I. N. Algorithm for Assessing Quality of Fuzzy Expert Information. Proceedings of IEEE East-West Design \& Test Symposium, Novi Sad, Serbia, September 29 - October 2, 2017, pp. 319-322. DOI: 10.1109/EWDTS.2017.8110107. 
29. Zareiforoush H., Minaei S., Alizadeh M. R., Banakar A., Samani B. H. Design, development and performance evaluation of an automatic control system for rice whitening machine based on computer vision and fuzzy logic // Computers and Electronics in Agriculture, 2016, vol. 124, 14-22. DOI: 10.1016/j.compag.2016.01.024.

30. Борисова Л. В., Димитров В. П., Нурутдинова И. Н. О методике представления нечётких экспертных знаний // Вестник Донского государственного технического университета. 2014. T. 14. N 4 (79). С. 93-102.

31. Nurutdinova I. N., Borisova L. V., Dimitrov V. P. On Creation of ExpertKnowledge Base in Information Systems of Decision Making Support. // International Journal of Fuzzy Systems and Advanced Applications, 2014, vol. 1, pp. 88-93.
32. Dimitrov V. P., Borisova L. V., Nurutdinova I. N. Modelling of Fuzzy Expert Information in the Problem of a Machine Technological Adjustment MATEC Web of Conferences, 2017, vol. 132, pp. 1-4. DOI: 10.1051/matecconf/201713204009.

33. Колоденкова А. Е. Нечетко-интервальный подход к оценке реалистичности проекта в условиях недоопределенности // Конгресс по интеллектуальным системам и информационным технологиям «IS\&IT'11»: Труды конгресса. М.: Физматлит, 2011. Т. 1. С. 213-217.

34. Бадалян Л. Х., Курдюков В. Н., Овчаренко А. М., Горшкова Ю. В. Анализ доминирующей в Российской Федерации методологии оценки влияния вредных выбросов на качество атмосферного воздуха // Устойчивое развитие горных территорий. 2018. Т. 10. № 2 (36). С. 307-314. DOI: 10.21177/1998-4502-2018-10-2-307-314.

\section{СВЕДЕНИЯ ОБ АВТОРАХ / Information about authors:}

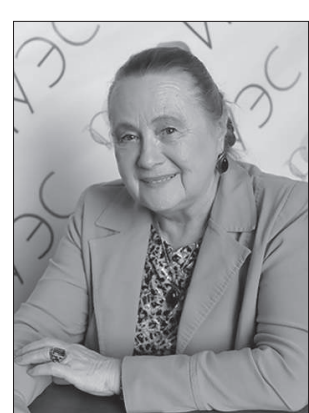

ГОРЕЛОВА Галина Викторовна - доктор технических наук, профессор. Инженерно-технологическая академия Южного федерального университета, 347922, г. Таганрог, Россия.

Тел.: 8(8634) 39-42-64,

gorelova-37@mail.ru

Galina V. GORELOVA - Doctor of Technical Sciences, Professor, Engineering-Technological Academy of the Southern Federal University, 347922, Russia, Taganrog.

Ph.:+7(8634)39-42-64, gorelova-37@mail.ru

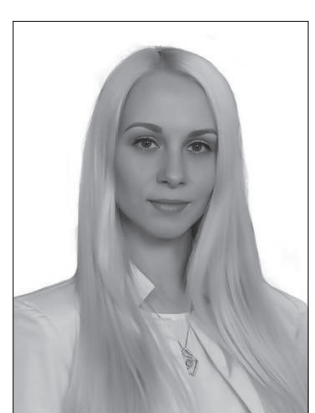

БОРИСОВА Дина Владимировна - ассистент кафедры «Менеджмент и бизнес-технологии», Донской государственный технический университет (ДГТУ), 344065 , г. Ростов-на-Дону, Россия.

Тел.: 8(8632)58-91-84,

borisovalv09@mail.ru

Dina VI. BORISOVA - Assistant of the Department of Management and Business Technology, Don State Technical University (DSTU), 344065, Russia, Rostov-on-Don. Ph.:+7(8632)58-91-84, borisovalv09@mail.ru

\section{COGNITIVE TOOLS FOR THE INTER-REGIONAL ECONOMIC INTEGRATION STUDY}

${ }^{1}$ G. V. Gorelova,

${ }^{2}$ D. V. Borisova *

${ }^{1}$ Engineering and Technological Academy of the Southern Federal University, 347922, Taganrog, Russia, gorelova-37@mail.ru

${ }^{2}$ Don State Technical University (DSTU), 344065, Rostov-on-don, Russia, borisovalv09@mail.ru

DOI: $10.21177 / 1998-4502-2019-11-1-65-78$

The study of interregional integration problems is an actual national economic task for any country. The economic, technological, resource, financial, informational, and other types of the interaction between two or more regional actors determine the interregional integration. Many works of both foreign and Russian authors are devoted to the study of various aspects of interregional integration. But these work spaid little attention to the development of the research methods of the interregional integration as a complex system. This is necessary to substantiate management decisions that contribute to the effective integration.

The purpose of the research was to develop a cognitive tool consisting of models, methods, software that allows to simulate the structure and behavior of a complex system. The task of this article was to present the developed cognitive tool, which complements the existing cognitive modeling schemes of the complex systems with fuzzy data processing methods, the calculation of the integral indicator of the interregional integration efficiency, the risk assessment of integration processes. Number of results of imitational cognitive modeling of interregional economic integration were present. The study was conducted on the information concerning the interregional relations in the Southern Russia.

A brief description of the basic elements of the theory of cognitive modeling of complex systems, a detailed diagram of the stages of cognitive modeling of the interregional economic integration, an example of a cognitive model, examples of analysis of various properties of the system, and scenarios of situations on this model were presented in this article. The results of the computational experiment to determine the stability, allocation of paths and cycles of the model, pulse simulation scenarios are illustrated. Compari- 
son of all the results of a computational experiment and their correlation with information on the interregional relations allows one to speak about the fact that the model data do not contradict the real data.

So, the use of the cognitive tools allows one to increase the validity and consistency of management decisions aimed at ensuring the effective functioning of the system. These studies belong to the direction of "Artificial Intelligence" in the composition of the cognitive sciences and are intended for use in the creation of the intelligent decision support systems.

Keywords: cognitive sciences, interregional integration, simulation, computational experiment.

\section{References}

1. Polyakova A. G., Gerasimova V. V. Theoretical aspects of studying of regional economic integration and social and economic space of the region. Intelligence. Innovations. Investments. 2010, no. 2, pp. 50-56. (in Russian)

2. Zhukova T. V. Borisova D. V. Interregional economic integration as instrument of sotsio-economic development. Economy and Entrepreneurship, 2017, no. 9, p.1, pp. 255258. (in Russian)

3. Stetsko N. I. Unevenness of economic development of regions in theories of the spatial organization of economic systems. Basic Researches, 2017, no. 6, pp. 185-189. (in Russian)

4. Ahunov R. R. The development of the interregional integration as a direction of increase of the competitiveness in the regions reproductive potential system. Bulletin USUES. Science, Education, Economy. Series Economy, 2016, no. 1 (15), pp. 7-16. (in Russian)

5. Modeling and management of processes of regional development. S. N. Vasil'eva es. Moscow, Fizmatlit, 2001, 432 p. (in Russian)

6. Volkova V. N., Denisov A. A. Bases of the theory of systems and system analysis. St. Petersburg, St.-Pt. SPUPubl., 2005, 520 p. (in Russian)

7. Katalevskiy A. Yu. Bases of imitating modeling and the system analysis in management. Moscow, MSU Publ., 2011, 304 p. (in Russian)

8. Maslennikova A. V. Dynamic model of interregional development of the Russian Federation for a research of strategy of management social-ecologist-economic regional processes. Management of development of large-scale systems (MLSD'2010). Proceedings of the Fourth International Conference, Moscow, IPM RAS of V. A. Trapeznikov, 2010, vol. 2, pp. 346-352. (in Russian)

9. Axelrod R. The Structure of Decision: Cognitive Maps of Political Elites. Princeton. University Press, 1976.

10. Atkin R. H. Combinatorial Connectivies in Social Systems. An Application of Simplicial Complex Structures to the Study of Large Organisations. Interdisciplinary Systems Research, 1997, $245 \mathrm{p}$.

11. Abramova N. A., Voronina T. A., Porcev R. Ju. About methods of support, construction and verification of cognitive maps with use of the ideas of cognitive graphics. Management of big systems. Moscow, IPM RAS, 2010, Special release 30.1, pp. 411-430 (in Russian)

12. Avdeeva Z. K. Heuristic method of conceptual structurization of knowledge at formalization of semistructured situations on the basis of cognitive maps. Management of Big Systems. Moscow, IPM RAS, 2010, Release 31, no. 3, pp. 6-34 (in Russian)

13. Casti J. Connectivity, complexity and catastrophe in large-scale systems. Chichester-New York-Brisbane-Toronto, $1979,216 \mathrm{p}$.

14. Kovriga S. V., Maksimov V. I. Cognitive technology of strategic management of development of difficult social and economic objects in the unstable external environment. Proceedings of the International Conference "Cognitive analysis and situations control» (CASC'2001), 2001, vol. 1. (in Russian)

15. Kul'ba V. V., Kononov D. A., Kovalevskij S. S., Kosjachenko S. A, Nizhegorodcev R. M., Chernov I. V. Scenario analysis of dynamics of behavior of social and economic systems. Moscow, IPM RAS, 2002, 122 p. (in Russian)

16. Roberts F. S. Discrete mathematical models with annexes to social, biological and ecological tasks. The transl. from the Eng. A. M. Rappoport, S. I. Travkin. Under A. I. Teyman's edition. Moscow, Nauka, 1986. 496 p. (in Russian)

17. Gorelova G. V., Zaharova E. N., Radchenko S.A. Research of semistructured problems of social and economic systems: cognitive approach. Rostov-on-Don, RSU Publ., 2006. 332 p. (in Russian)

18. Ginis L. A., Gorelova G. V., Kolodenkova A. E. Cognitive and simulation modeling of Socioeconomic systems. Proceedings of the International Research Conference Information Technologies in Science, Management, Social Sphere and Medicine (ITSMSSM 2017), 2017, vol. 72, pp. 50-54.

19. Gorelova G. V., Pankratova N. D. Scientific Foresight and Cognitive Modeling of Socio-Economic Systems. IFAC Proceedings Volumes, 18th IFAC Conference on Technology, Culture and International Stability TECIS, 2018, pp. 145-149.

20. Zaharova E. N., Pankratova N. D. To a question of a possibility of development and the analysis of strategy and programs of development of territories by means of cognitive imitating modeling. Bulletin of the $A S U, 2015$, no. 4 (170), pp. 182-195 (in Russian)

21. Innovative development of socioeconomic systems on the basis of methodologies of anticipation and cognitive modeling. G. V. Gorelov, N. D. Pankratov es. Kiev, Naukova Dumka, 2015, 464 p. (in Russian)

22. Ismihanov Z. N.Modeling of social and economic development of the region on the basis of cognitive approach(on the example of the Republic of Dagestan). Business informatics, 2015, no. 2 (32), pp. 59-68 (in Russian)

23. Ismihanov Z. N., Omarova N. O., Aripova P. G., Umargadzhieva N. M., Magomedov M. S.Structuring knowledge and cognitive map for scenario forecasting of the situation development in the region. Espacios, 2017, vol. 38, no. 33 , pp. 7 .

24. The program for cognitive modeling and analysis of socio-economic systems of the regional level. Certificate on the state registration of the computer programs N2018661506 of 07.09.2018. (in Russian)

25. Kosko B. Fuzzy Cognitive Maps. Intern. Journal of Man-Machine Studies, 1986. vol. 24, pp. 65-75.

26. Kosko B. Fuzzy Thinking: The New Science of Fuzzy Logic. Hyperion. Disney Books, 1993. 336 p.

27. Zadeh L. A. Knowledge representation in fuzzy logic. 
An Introduction to Fuzzy Logic Applications in Intelligent Systems. In: The Springer International Series in Engineering and Computer Science. Boston, Springer, 1992, vol. 165, pp. 1-27. DOI: 10.1007/978-1-4615-3640-61254.

28. Dimitrov V. P., Borisova L. V., Nurutdinova I. N. Algorithm for Assessing Quality of Fuzzy Expert Information. Proceedings of IEEE East-West Design \& Test Symposium, Novi Sad, Serbia, September 29 - October 2, 2017, pp. 319 322. DOI: 10.1109/EWDTS.2017.8110107.

29. Zareiforoush H., Minaei S., Alizadeh M. R., Banakar A., Samani B. H. Design, development and performance evaluation of an automatic control system for rice whitening machine based on computer vision and fuzzy logic. Computers and Electronics in Agriculture, 2016, vol. 124, 14-22. DOI: 10.1016/j.compag.2016.01.024.

30. Borisova L. V., Dimitrov V. P., Nurutdinova I.N. About a technique of representation of indistinct expert knowledge. Bulletin of the Don State Technical University, 2014, vol. 14. no. 4 (79), pp. 93-102. (in Russian)

31. Nurutdinova I. N., Borisova L. V., Dimitrov V. P. On Creation of ExpertKnowledge Base in Information Systems of Decision Making Support. International Journal of Fuzzy Systems and Advanced Applications, 2014, vol. 1, pp. 88-93.

32. Dimitrov V. P., Borisova L. V., Nurutdinova I. N. Modelling of Fuzzy Expert Information in the Problem of a Machine Technological Adjustment MATEC Web of Conferences, 2017, vol. 132, pp. 1-4. DOI: 10.1051/matecco$\mathrm{nf} / 201713204009$.

33. Kolodenkova A. E. Indistinct and interval approach to assessment of realness of the project in the conditions of uncertainty. Works of the Congress on Intellectual Systems and Information "IS\&IT'11». Moscow, Fizmatlit, 2011, vol. 1, pp. 213-217. (in Russian)

34. Badalian L. Kh., Kurdyukov V. N., Ovcharenko A. M., Gorshkova Y. V. Analysis of Standards and Methodology For Assessing Impact of Emissions on the Atmospheric Air Quality Prevailing in Russian Federation. Sustainable Development of Mountain Territories, 2018, vol. 10, no 2(36), pp. 307-314. DOI: 10.21177/1998-4502-2018-10-2307-314.

Article received 03.10.2018. 


\section{ДОИЗМЕЛЬЧЕНИЕ ПРОМПРОДУКТОВ ОБОГАЩЕНИЯ МЕДНО-ПИРИТНОЙ РУДЫ В МЕЛЬНИЦЕ ДР-500}

${ }^{1}$ Клыков Ю. Г., *

'Дмитрак Ю. В., 'Байматов К. К., ${ }^{2}$ Клыкова В. Б.
Введение. Одним из способов повышения эффективности обогащения медно-пиритной руды является применение схемы обогащения с доизмельчением промпродуктов в замкнутом цикле, позволяющее получить более полное извлечение ценных компонентов из руды [1-4]. Решению этой задачи способствует применение эффективного оборудования для доизмельчения [5-7].

С учетом требований к селективности измельчения руд считаем, что перспективным направлением является применение мельницы доизмельчения ДР-500 [8; 9]. Одновременно отмечаем, что физико-механические свойства измельчаемого материала весьма существенно влияют на эффективность измельчения и определяются его минералогическим составом. Раскрытие минералов и крупность измельченных частиц во многом определяют технологические требования обогащения, в данном случае процессу флотации. Больший выход тонких и труднообогатимых классов значительно снижает эффективность флотации [14-16].

Методика испытаний. Исследования проводились в условиях Урупского горно-обогатительного комбината при доизмельчении промпродуктов первой перечистки медного концентрата в мельнице ДР-500, шаровой мельнице МШЦ 2700х3600, стержневой мельнице МС 300х200. Исходная крупность промпродуктов составляла $-0,25$ мм.

На первом этапе проводились сравнительные испытания вышеуказанных мельниц при непрерывном режиме измельчения в открытом цикле. Определялась производительность мельниц и крупность измельченного материала.

Количественной оценкой процесса измельчения (доизмельчения) является коэффициент измельчаемости $[10 ; 11]$ :

$$
K_{u}=\frac{q_{p}}{\left(q_{p}\right)_{\ni}}
$$

где $q_{p}$ - удельная производительность мельницы по расчетному классу $-0,074$ мм по исследуемой руде, т/(м³) ч)

$\left(q_{p}\right)_{\ni}$ - удельная производительность мельницы по расчетному классу $-0,074$ мм по эталонной руде, т/(м³ ч).

На втором этапе проводились сравнительные испытания мельницы ДР-500 и стержневой мельнице МС 300х200 при непрерывном режиме измельчения в открытом цикле. Влияние крупности продукта доизмельчения и степени раскрытия минералов на эффективность процесса проводились по методике $[12 ; 13]$. За эталонную руду была принята медная сульфидная руда Джезказганского месторождения подземной добычи $[17 ; 18]$. Проводилась флотация измельченного продукта, и определялись результаты извлечения меди в концентрат.

На третьем этапе проводились сравнительные испытания мельницы ДР500 и МШЦ 2700х3600 в замкнутом цикле с гидроциклоном.

\footnotetext{
${ }^{1}$ Северо-Кавказский горно-металлургический институт (государственный технологический университет), 362021, Владикавказ, Россия, klikovu@mail.ru

${ }^{2}$ Филиал Ростовского государственного университета путей сообщения «Владикавказский техникум железнодорожного транспорта», 362027, Владикавказ, Россия
}

\section{УДК: 622.73}

DOI: 10.21177/1998-4502-201911-1-79-84

Проведены исследования эффрективности мельницы ДР-500 для доизмельчения песков медно-пиритных промпродуктов Урупского горно-обогатительного комбината.

В результате испытаний была установлена относительная измельчаемость медно-пиритных промпродуктов в мельнице ДР-500 по классам крупности -0,074 мм и -0,2 мм. Была подтверждена гипотеза о селективном механизме разрушения материала по плоскостям срастания минерала с жильными минералами вмещающей породы.

Были получены данные по извлечению меди в концентрат, при этом установлено, что зерна полезного минерала при измельчении в мельнице ДР-500 крупнее и лучше раскрыты, чем при измельчении в стержневой мельнице МС $300 \times 200$. Определено, что наиболее эфрфективная циркуляционная нагрузка 207 \% для мельницы ДР-500 достигается при расходе воды 1,46 m/4. В этом случае удельная производительность по кл. -0,074 мм и содержание этого класса в продукте измельчения имеют максимальное значение.

Для получения более тонкого помола песков меднопиритных промпродуктов в мельнице ДР-500 рекомендуется применение замкнутого цикла измельчения с классифицирующими аппаратами.

КЛЮЧЕВЫЕ СЛОВА:

медно-пиритная руда, промпродукты, доизмельчение, мельница доизмельчения, грансостав, коэффрициент измельчаемости, минералогический состав, извлечение меди в концентрат, замкнутый цикл.

Статья поступила в редакцию 13.02.2019 
Результаты испытаний и обсуждение

Результаты анализа грансоставов измельченного продукта разгрузок мельницы ДР-500, мельницы МШЦ 2700x3600 и стержневой мельницы МС 300x200 приведены в табл. 1.

Гранулометрический состав продуктов измельчения, \%

Таблица 1 / Table 1 Granulometric composition of grinding products, \%

\begin{tabular}{|c|c|c|c|c|}
\hline \multirow{2}{*}{ Тип мельницы / Mill type } & \multicolumn{4}{|c|}{ Выход классов, мм / Classes output, mm } \\
\hline & $+0,2$ & $-0,200+0,074$ & $-0,074+0,044$ & $-0,044$ \\
\hline $\begin{array}{l}\text { Исходный материал } \\
\text { Source material }\end{array}$ & 12,2 & 70,5 & 16,1 & 1,2 \\
\hline $\begin{array}{c}\text { Мельница доизмельчения ДР-500 } \\
\text { DR-500 Grinding mill }\end{array}$ & 1,0 & 62,2 & 21,3 & 15,5 \\
\hline $\begin{array}{c}\text { Шаровая МШЦ 2700x3600/ } \\
\text { Ball MSC 2700x3600 }\end{array}$ & 0,5 & 50,2 & 24,4 & 24,9 \\
\hline $\begin{array}{c}\text { Стержневая МC 300x200 } \\
\text { Core MS 300x } 200\end{array}$ & 0,8 & 56,9 & 22,1 & 20,2 \\
\hline
\end{tabular}

Коэффициенты измельчаемости промпродуктов приведены на рис. 1.

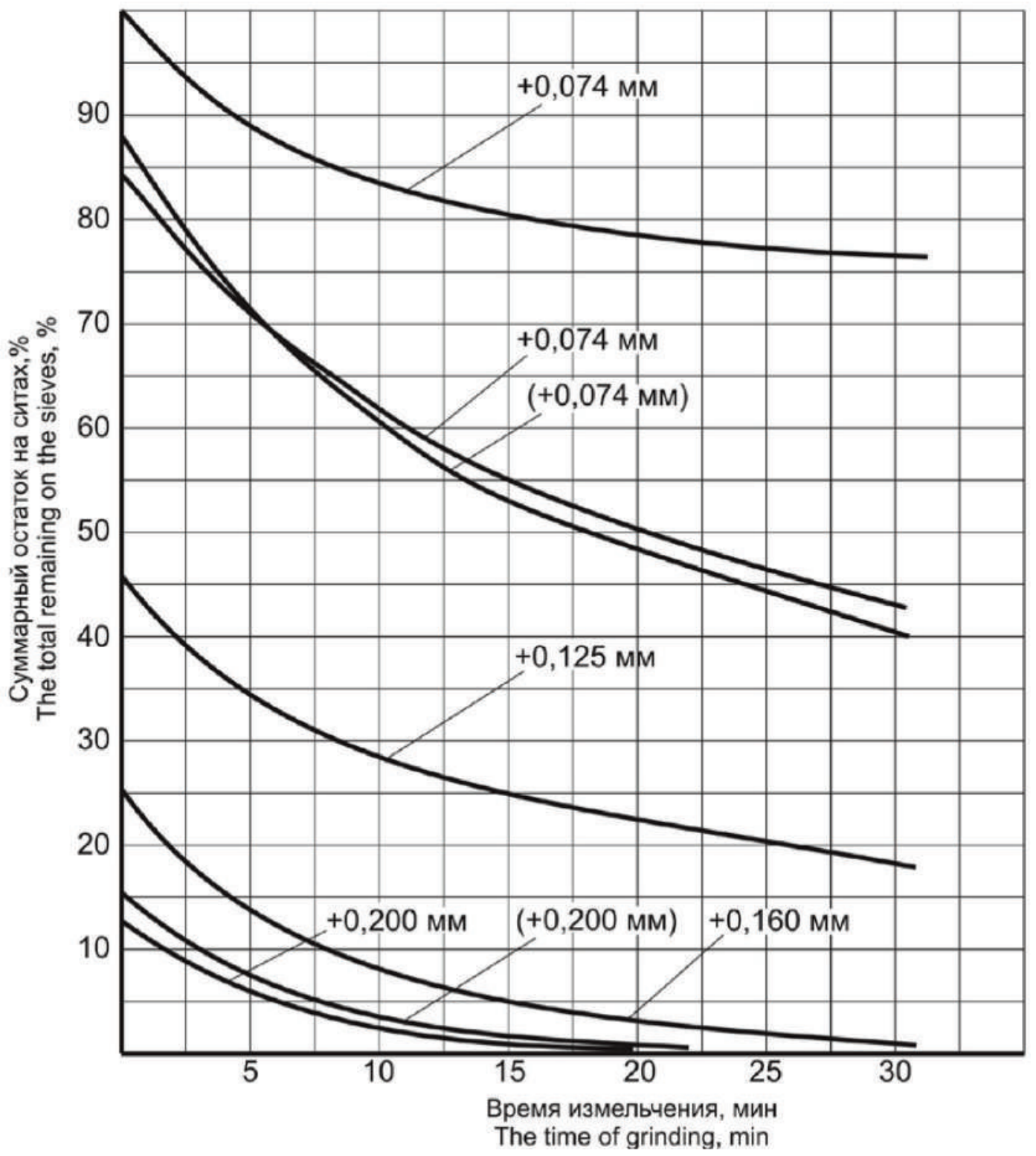

Рис. 1. Коэффициенты измельчаемости промпродуктов

Fig. 1. Grinding curves of industrial products 
В результате произведенных расчетов при доизмельчении промпродуктов первой перечистки медного концентрата в мельнице ДР-500 была установлена относительная измельчаемость по расчетному кл. $-0,074$ мм $\mathrm{k}_{\mathrm{i}}^{74}=0,86$, а по расчетному кл. $-0,2$ мм $\mathrm{k}_{\mathrm{i}}^{200}=0,90$. При этом была подтверждена гипотеза о селективном механизме разрушения материала по плоскостям срастания минерала с жильными минералами вмещающей породы.

Результаты испытаний мельниц показывают, что содержание крупных классов в разгрузке всех типов мельниц примерно равное, а содержание класса $-0,044$ мм в разгрузке мельницы ДР-500 на 5-9\% меньше, чем в разгрузке шаровой и стержневой мельниц. Удельная производительность мельниц в диапазоне $40-70 \%$ по кл. -0,074 мм практически одинакова.

На втором этапе были проведены сравнительные испытания мельницы ДР-500 и стержневой мельницы МС 300х200. Продукты измельчения этих мельниц подвергали флотации при стандартных условиях проведения экспериментов и статистической обработки результатов.

В результате получены данные по извлечению меди в концентрат:

мельница доизмельчения $\bar{\varepsilon}=89,67 \% ; S_{x}=2,403$;

стержневая мельница $S_{x}=85,1 \% ; S_{x}=2,614$.

Повышение извлечения меди в концентрат при доизмельчении промпродукта в мельнице ДР-500 можно объяснить большей степенью раскрытия сростков минералов с жильными породами по границам их срастания, т.е. селективностью измельчения [19;20].

Для определения степени селективности измельчения были подготовлены представительные минералогические «полированные пробы» по стандартной методике. Минералогическое изучение аншлифов показало, что главными рудными минералами исследуемой руды являются халькопирит, менее распро- странен борнит и еще меньше халькозин. Из второстепенных минералов преобладает пирит, в незначительном количестве отмечаются блеклые руды, сфалерит и единичные включения галенита. Из жильных минералов широко развит кварц. Минералогический состав всех проб одинаков, различия заключаются в количестве обломков, содержащих минералы полезного компонента и сопутствующих. Процентное содержание сростков полезного компонента с обломками пустой породы, подсчитанное по площади минералов на всей поверхности аншлифов хвостов флотации, почти в два раза ниже для мельницы доизмельчения, чем для стержневой мельницы (табл. 2). В аншлифах хвостов флотации продукта, измельченного в стержневой мельнице наблюдались сростки полезного минерала с жильными породами - пиритом, кварцем, которых почти нет в хвостах флотации продукта, измельченного в мельнице доизмельчения. В аншлифах концентратов флотации видно, что зерна полезного минерала при измельчении в мельнице ДР-500 крупнее и лучше раскрыты, чем при измельчении в стержневой мельнице МС 300×200.

На третьем этапе проводились сравнительные испытания мельницы ДР-500 и МШЦ 2700х3600 в замкнутом цикле с гидроциклоном. Исходным материалом являлись пески гидроциклонов первой перечистки крупностью - 0,25 мм с содержанием по кл. $-0,074$ мм $-14,6 \%$.

Цель испытаний - получение тонкого слива гидроциклона с содержанием по кл. -0,074 мм - 85-90\%. Определяемые параметры - циркуляционная нагрузка, весовое количество песков, содержание расчетного кл. -0,074 мм в сливе гидроциклона. Содержание твердого в цикле регулировалось путем изменения расхода воды.

Исследования показали, что по мере повышения плотности слива гидроциклона выход кл. -0,074 мм

Сравнительные показатели минералогического анализа

Таблица 2 / Table 2

Comparative indicators of mineralogical analysis

\begin{tabular}{|c|c|c|c|}
\hline $\begin{array}{c}\text { Номер } \\
\text { аншлифа }\end{array}$ & $\begin{array}{c}\text { Содержание обломков с } \\
\text { полезным компонентом, \% }\end{array}$ & $\begin{array}{c}\text { Материал, из которого } \\
\text { изготовлен аншлиф }\end{array}$ & Мельне \\
$\begin{array}{c}\text { Numb the polished } \\
\text { section }\end{array}$ & $\begin{array}{c}\text { The contents of the wreckage } \\
\text { with the useful component, \% }\end{array}$ & $\begin{array}{c}\text { Material } \\
\text { the full-length is made }\end{array}$ & Mill \\
\hline $1 ; 2$ & 0,9 & $\begin{array}{c}\text { хвосты } \\
\text { tails }\end{array}$ & $\begin{array}{c}\text { мельница доизмельчения ДР-500 } \\
\text { DR-500 grinding mill }\end{array}$ \\
\hline $3 ; 4$ & 5,29 & $\begin{array}{c}\text { концентрат } \\
\text { concentrate }\end{array}$ & $\begin{array}{c}\text { стержневая MC 300х200 } \\
\text { core MS 300х200 }\end{array}$ \\
\hline $5 ; 6$ & 1,9 & $\begin{array}{c}\text { хвосты } \\
\text { tails }\end{array}$ & $\begin{array}{c}\text { стержневая MC 300х200 } \\
\text { core MS 300х200 }\end{array}$ \\
\hline $7 ; 8$ & 5,5 & $\begin{array}{c}\text { концентрат } \\
\text { concentrate }\end{array}$ & $\begin{array}{c}\text { стержневая MC 300х200 } \\
\text { core MS 300х200 }\end{array}$ \\
\hline
\end{tabular}




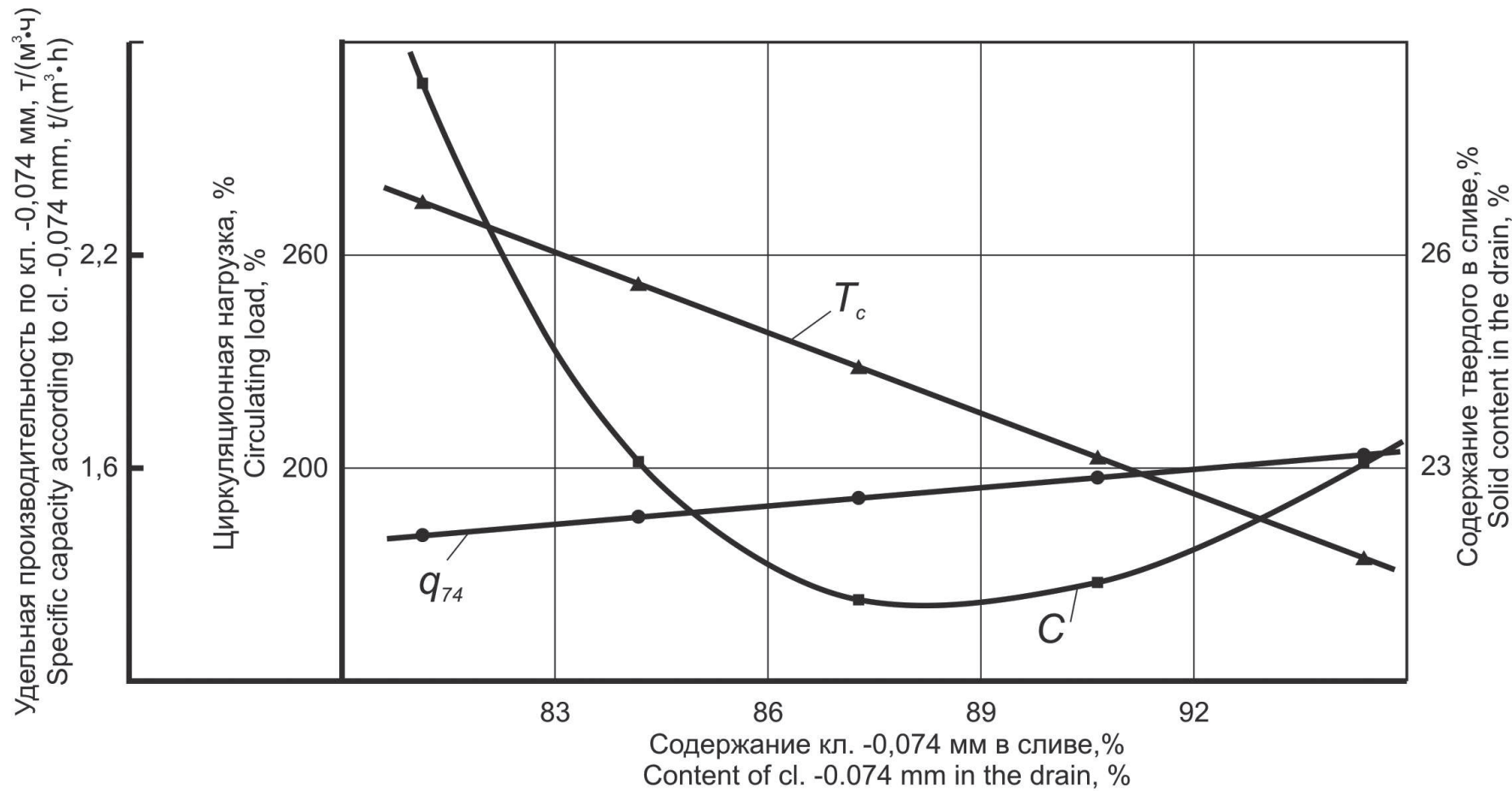

Pис. 2. Взаимосвязь показателей измельчения в замкнутом ияикле

Fig. 2. The relationship between grinding parameters in a closed cycle

плавно уменьшается. Изменение происходит по линейной зависимости, которой соответствует уравнение

$$
\beta_{74}=148,2-2,5 \cdot T_{c},
$$

где $T_{\mathrm{c}}$ - плотность слива.

Расхождение между опытными и расчетными данными не превышало 1,5\%, что находится в пределах погрешности ситовых анализов.

Наивыгоднейшая циркуляционная нагрузка (207\%) достигалась при расходе воды 1,46 т/ч. В этом случае удельная производительность по кл. -0,074 мм и содержание этого класса в продукте измельчения имела максимальное значение (рис. 2).

\section{Выводы}

1. Проведены сравнительные испытания мельницы доизмельчения ДР-500, шаровой мельницы МШЦ $2700 x 3600$ и стержневой мельницы МС 300х200 в условиях Урупского горно-обогатительного комбината

\section{ЛИТЕРАТУРА:}

1. Плаксин В.И., Кармазин В.И., Кармазин В.В., Олофинский Н.Ф. Новые направления в обогащении тонковкрапленных руд. М.: Наука, 1964.

2. Harwell J. Sarfactants for ground water remediation // Colloids Surf. A: Physicochem. Eng. Aspects. 1999. vol. 151, 255-268, Apr. 1999.

3. Клыков Ю.Г. Анализ измельчаемости медно-пиритных промпродуктов на Урупском ГОКе // Колыма. 1987. N 9.

4. Cavanaugh W.J. and Rodgers D.J. Applications of the Snyder process. Tenth International Mineral Processing Congress. London: 1973. P. 46. при доизмельчении промпродуктов первой перечистки медного концентрата.

2. Установлено, что относительная измельчаемость мельницы ДР-500 по расчетному кл. -0,074 мм составляет $k_{i}^{74}=0,86$, а по расчетному кл. $-0,200$ мм $-k_{i}^{200}=0,9$, что выше аналогичных показателей для шаровой и стержневой мельниц.

3. Содержание фракции -0,4 - -0,16 мм при измельчении медно-пиритной руды в мельнице ДР-500 составляет более 70\%, а при содержании класса $-0,074$ мм - 3,9\%.

4. Количество сростков при измельчении меднопиритной руды в мельнице доизмельчения ДР-500 не превышает 5\%, а степень раскрытия - 0,88.

5. Наивыгоднейшая циркуляционная нагрузка (207 \%) при использовании мельницы ДР-500 достигается при расходе воды 1,46 т/ч при максимальной удельной производительности по кл. -0,074 мм.

5. Jansen Y. Die Regenerieung von Formstoffenbesonders von kunstharsdebunden Altsandenen // Giesserey. 1972. Vol. 59. P. 599.

6. Maier H. Kinetik der Hartzerkleinerung // Aufbereitungs. Technic. 1965. N1. P. 1.

7. Справочник по проектированию рудных обогатительных фабрик. В 2 кн. / Редкол.: О.Н. Тихонов и др. М.: Недра, 1988; Кн.1 / В.Ф. Баранов, П.С. Вольфсон, П.И. Круппа и др. С. 374

8. Matheron J. Fundamentals of applied geostatistics. Moscow: Mir, 1968. 217 c. 
9. Разумов К. А., Перов В. А. Проектирование обогатительных фабрик. Учебник для ВУЗов. 4 изд., перераб. и доп. М.: Недра, 1982. 518 с.

10. Разумов К.А. Проектирование обогатительных фабрик. Изд. 3, перераб. и доп. М.: Недра, 1970. 592 с.

11. Справочник по обогащению руд. Подготовительные процессы / Под ред. О.С. Богданова, В.А. Олевского, 2 изд., перераб. и доп. М.: Недра, 1982. 366 с.

12. Справочник по обогащению руд. Основные процессы / Под ред. О.С. Богданова, 2 изд., перераб. и доп. М.: Недра, 1983. 381 с.

13. Klykov Yu. Some provisions of the theory of separation of solids during grinding // Danish Scientific Journal. 2017. N 4. Pp. 92-96.

14. Справочник по проектированию рудных обогатительных фабрик: в 2 кн. / Редкол. О.Н. Тихонов и др.; Кн. 2 / Г.И. Адамов, В.Ф. Баранов, Б.П. Бутусов и др.
15. Ashcroft N., Mermin N. Physics of the solid state. Moscow: Nauka, 1979.

16. Козин В.3. Опробование и контроль технологических процессов обогащения. М.: Недра, 1985.

16. Goden M.A. Fundamentals of minerals enrichment. Moscow: Metallurgizdat, 1946.

17. Справочник (кадастр) физических свойств горных пород // Под ред. Мельникова Р.Д., Ржевского В.В., Протодьяконова М.М. М.: Недра, 1975.

18. Ягупов А.В., Выскребенец А.С. О коэффициенте внутреннего трения в мелкозернистом угле // Теплоэнергетика. 1980. N4.

19. Хуэто А.А., Тихонов О.Н. Прогноз энергии измельчения с учетом гранулометрических характеристик материалов // Изв. Вузов. Цветная металлургия. 1992. N3-4.

20. Клыков Ю.Г. К вопросу о переработке хвостов обогатительных фабрик // Устойчивое развитие горных территорий. 2013. N2 (16). С. 37-39.

\section{СВЕДЕНИЯ ОБ АВТОРАХ / Information about authors:}

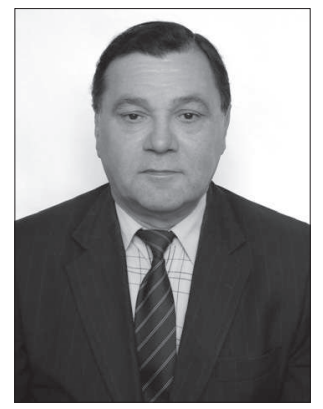

КЛЫКОВ Юрий Георгевич доктор технических наук, профессор.

Северо-Кавказский горно-металлургический институт (государственный технологический университет), 362021, РСО-Алания, г. Владикавказ, Россия.

Тел.: (918) 825-92-94

E-mail: klikovu@mail.ru

Yuri G. KLYKOV - Doctor of Technical Sciences, Full Professor. North-Caucasian Institute of Mining and Metallurgy (State Technological University), 362021, Vladikavkaz, Russia.

Ph.: (918) 825-92-94

E-mail:klikovu@mail.ru

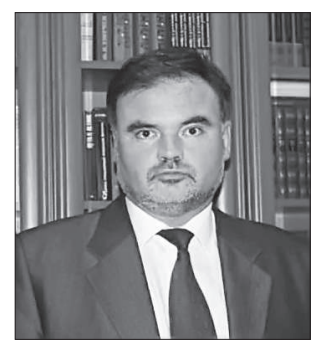

ДМИТРАК Юрий Витальевич - доктор технических наук, профессор; ректор.

Северо-Кавказский горно-металлургический институт (государственный технологический университет), 362021, РСО-Алания, г. Владикавказ, Россия.

Тел.: (8672) 40-71-00.

E-mail: dmitrak@yandex.ru

Yuri V. DMITRAK - Doctor of Technical Sciences, Full Professor; Rector. North-Caucasian Institute of Mining and Metallurgy (State Technological University), 362021, Vladikavkaz, Russia.

Ph.: (8672) 40-71-00.

E-mail:dmitrak@yandex.ru

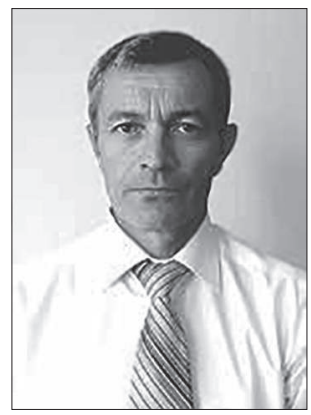

БАЙМАТОВ Казбек Константинович - кандидат технических наук, доцент.

Северо-Кавказский горно-металлургический институт (государственный технологический университет), 362021, РСО-Алания, г. Владикавказ, Россия.

Тел.: (8672) 52-06-97

E-mail: kaz-60@mail.ru

Kazbek K. BAIMATOV - Candidate of Technical Sciences, Associate Professor. North-Caucasian Institute of Mining and Metallurgy (State Technological University), 362021, Vladikavkaz, Russia.

Ph.: (8672) 52-06-97

E-mail:kaz-60@mail.ru

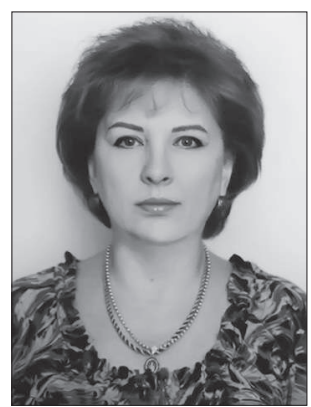

КЛЫКОВА Валерия Борисовна - преподаватель. Филиал Ростовского государственного университета путей сообщения «Владикавказский техникум железнодорожного транспорта», 362027, Владикавказ, Россия.

Тел.: +7 (918) 829-71-14.

E-mail: ler. c. klikova@mail.ru

Valeria B.KLYKOVA-Teacher.

Branch of Rostov State Transport University "Vladikavkaz Railway Technical College", 362027, Vladikavkaz, Russia.

Ph.: +7 (918) 829-71-14.

E-mail:ler.c.klikova@mail.ru 


\section{MILLING OF THE COPPER-PYRITICORE ENRICHMENT PRODUCT IN THE MILL DR-500}

${ }^{1}$ Yu. G. Klykov, *

${ }^{1}$ Yu. V. Dmitrak,

${ }^{1}$ K. K. Baimatov,

${ }^{2}$ V. B. Klykova.

${ }^{I}$ North-Caucasian Institute of Mining and Metallurgy (State Technological University),362021, Vladikavkaz, Russia, E-mail:klikovu@mail.ru

${ }^{2}$ Vladikavkaz College of Railway Transport, Branch of Rostov State University of road ways. 362027, Vladikavkaz, Russia

DOI: $10.21177 / 1998-4502-2019-11-1-79-84$

The results of comparative tests of the regrinding mill DR-500, the ball mill MShT 2700x3600 and the core mill MS 300x200operation with the regrinding of the sands of copper-pyrite middling's under the conditions of the Urup mining and processing plant are presented. As a result of the tests, the relative grindability of copper-pyrite middling was established in the grinding regimen DR-500 according to the calculated grade, $-0,074 \mathrm{~mm}=0,86$, and according to the calculated grade. $-0.2 \mathrm{~mm}=0.90$. The hypothesis about the selective mechanism of the material destruction along the planes of the mineral fusion with the vein minerals of the host rock was confirmed.

As a result of the comparative tests of the regrinding mill DR-500 and the core mill MS 300x200, the data were obtained for the extraction of copper into the concentrate: the core mill was $85.1 \% ; 2,614$ and grinding mill 89,67\%; 2.403 . The mineralogical study of the polished sections showed that the grains of the useful mineral when grinding in the mill for regrinding DR-500 are larger and better disclosed than when grinding in the rod mill MS 300x200.

The comparative tests of the regrinding mill DR-500 and the MSC 2700x3600 mill in the closed cycle with hydrocyclone showed that the most effective circulation load of $207 \%$ for the DR-500 mill is achieved with water consumption of $1.46 \mathrm{t} / \mathrm{h}$. In this case, the specific productivity of class, $-0.074 \mathrm{~mm}$ and the content of this class in the grinding product have the maximum value.

It was revealed that in order to obtain more fine grinding of ore in the DR-500 mill it is desirable to use a closed grinding cycle with classifying devices.

Keywords: copper pyrite ore, middling, regrinding, regrinding mill, grain composition, coefficient of grindability, mineralogical composition, extraction of copper into concentrate, closed cycle.

\section{References}

1. Plaksin V. I., Karmazin V. I., Karmazin V. V., Olowinsky N. F. New directions in enrichment of the fine-ore. Moscow, Nauka, 1964.

2. Harwell J. Sarfactantsfor ground water remediation. Colloids Surf. A: Physicochem, Eng. Aspects, 1999, Vol. 151, 255-268, Apr. 1999.

3. Fangs Y. H. Analysis of work copper-pyrite middlings in Urupsky GOK. Kolyma,1987, no. 9.

4. Cavanaugh W.J. and Rodgers D.J. Applications of the Snyder process. Tenth International Mineral Processing Congress, London, 1973, pp. 46.
5. Jansen Y. The regeneration of moldings, especially of synthetic resin bands of old sand. Giesserey, 1972, Vol. 59, pp. 599.

6. Maier H.Kinetics of hard reduction. Preparation. Technic, 1965, no.1, p. 1.

7. Guide to the design of ore dressing plants. Moscow, Nedra, 1988; Vol.1 / V. F. Baranov, P. S. Wolfson, P. I. Krupp and others, p. 374.

8. Matheron J. Fundamentals of applied geo-statistics. Moscow, Mir, 1968, 217 p.

9. Razumov K. A., Perov V. A. Design of concentrating plants. Textbook for high schools. 4 iss. Moscow, Nedra, 1982, $518 \mathrm{p}$.

10. Razumov K. A. Design of concentrating plants. Iss. 3. Moscow, Nedra, 1970, 592 p.

11. Guide to ore dressing. Preparatory processes. Eds. O. S. Bogdanov, V. A. Olevsky, 2 iss., Moscow, Nedra, 1982, $366 \mathrm{p}$.

12. Guide to ore dressing. The main processes.O. S. Bogdanov ed., 2 iss. Moscow, Nedra, 1983, 381 p.

13. Klykov Yu. Some provisions of the theory of separation of solids during grinding. Danish Scientific Journal, 2017, no. 4, pp. 92-96.

14. Guide to the design of ore dressing plants. Adamov, V. F. Baranov, B. P. Butusov, etc. Moscow, Nedra, 1988. 341 p.

15. Ashcroft N., Mermin N. Physics of the solid state. Moscow, Nauka, 1979.

16. Kozin V. Z. Testing and control of technological processes of enrichment. Moscow, Nedra, 1985.

16. Goden M.A. Fundamentals of minerals enrichment. Moscow, Metallurgizdat, 1946.

17. Handbook (cadastre) of physical properties of rocks. R. D. Melnikov, V. V. Rzhevsky, Protodyakonov M. M. (eds.). Moscow, Nedra, 1975.

18. Yagupov A.V., Miscreants A. C. The coefficient of internal friction in fine-grained coal. Teploenergetika, 1980, no. 4 .

19. Hueto A. A., Tikhonov O. N. Forecast of grinding energy taking into account the granulometric characteristics of materials. Izv. Higher Educational. Nonferrous Metallurgy, 1992, no. 3-4.

20. Fangs Y. G. To the question about the reprocessing of tailings from processing plants. Sustainable Development of Mountain Territories, 2013, no. 2 (16), pp. 37-39.

Article received 13.02.2019. 


\section{МОДЕЛИРОВАНИЕ ПАРАМЕТРОВ ФУНКЦИОНИРОВАНИЯ ВЫЕМОЧНОЙ МАШИНЫ С ВИБРАЦИОННЫМ ВОЗДЕЙСТВИЕМ НА ГОРНЫЕ ПОРОДЫ}

\begin{abstract}
Введение
Приоритетным направлением развития базовых отраслей промышленности являются повышение конкурентоспособности российских производителей на рынке и поддержка экспорта российской промышленной продукции [1]. Одним из аспектов реализации этого направления является увеличение полноты извлечения полезного ископаемого из недр при добыче углей из пластов мощностью $2,0 \ldots 5,0$ м и углом падения менее $18^{\circ}$, в которых локализованы до половины промышленных запасов действующих шахт, в том числе высококачественных углей дефицитных марок.

Одной из причин недостаточных темпов добычи углей и проходки горных выработок в смежных отраслях является отсутствие высокотехнологичной выемочной техники для добычи угля из тонких и сверхтонких пластов, тогда как при строительстве предприятий для горных выработок необходимы горные машины с низкой удельной энергоёмкостью.

В настоящее время при отработке тонких и сверхтонких пластов широко используются очистные комбайны, недостатками которых являются высокий удельный расход электроэнергии на выемку 1 т угля и ограниченная скорость подачи комбайна (до 10-12 м/мин). Поэтому создание современной эффективной горной техники для разработки маломощных угольных пластов становится одной из важнейших проблем угольной промышленности.

Основу решения этой проблемы составляет разработка эффективного выемочного агрегата в составе лавного механизированного угледобывающего комплекса. Элементом решения этой проблемы является создание рабочего органа выемочной машины комбинированного действия, сочетающего процессы резания и отрыва горной массы с одновременным вибрационным воздействием его на забой с целью снижения энергоёмкости добычи полезного ископаемого.
\end{abstract}

До настоящего времени составляющие факторы такого рабочего органа существовали раздельно: чистое резание - на цепных и шнековых машинах; отрыв и удар - на струговых установках; ударно-вибрационное разрушение - отбойным молотком. Использование новых принципов разрушения минералов при их выемке является реальным резервом в горном деле [2; 3].

Для решения задач функционирования рабочего органа выемочной машины известны работы Хорина В.А., Мамонтова С.В., Солода Г.И., Солода В.И., Гетопанова В.А., Коваля П.В., Рачека В.М. и других, в которых рассматриваются механизм воздействия рабочего органа выемочной машины на минералы, реакция разрушаемого материала и взаимосвязь энергетических и режимных параметров выемочной машины и окружающей среды, динамика затрачиваемой на отделение угля от массива мощности в зависимости от скорости подачи выемочной машины и другие аспекты. Было отмечено, что снижение энергетических затрат на выемку полезного ископаемого и улучшение его сортности зависят от конструктивных особенностей рабочего органа $[4 ; 5]$.

Новым направлением совершенствования горных машин на основе использования скоростной технологии выемки полезных ископаемых является

${ }^{1}$ Акционерное общество «Центральный проектно-технологический институт» (АО «ЦПТИ»), 115409, Москва, Россия

\section{${ }^{1}$ Тарасов М.A.}

\section{УДК: 504.55.054:622(470.6)} DOI: 10.21171/1998-4502-2019$11-1-85-97$

Обосновано направление снижения энергоæмкости выемочной горной машины с комбинированным воздействием на очистной забой. Разработан алгоритм определения параметров рабочего органа выемочной горной машины и получена математическая модель его функционирования исходя из обеспечения производительности и минимальной энергоемкости разрушения минералов. Приведены результаты проверки адекватности математической модели функционирования рабочего органа выемочной машины стендовыми исследованиями эфрфективности вибрационного резания минералов. Показано что вибрационное резание минералов эфрфективно, если амплитуда колебаний рабочего инструмента больше отделяемой режущим инструментом толщины стружки. Параметры вибровозбудителей радиально направленных колебаний рабочего органа рекомендованы к использованию при разработке конструкторской документации выемочной машины для использования при добыче минерального сырья и проходке горных выработок в горнодобывающей отрасли и смежных отраслях народного хозяйства.

\section{КЛЮЧЕВЫЕ СЛОВА:}

выемочная машина, энергоæмкость, комбинированное воздействие, рабочий орган, математическая модель, вибрационное резание, добыча сырья, проходка выработок.

Статья поступила в редакцию 03.10.2018 
комбинирование струговой и комбайновой технологии с дифференциацией режимных параметров выемочных машины, в том числе скоростей резания и подачи. Использование новых принципов разрушения минералов при их выемке является реальным резервом в горном деле и может быть с эффектом реализовано при получении точности и достоверности теоретических и экспериментальных исследований по существу проблемы [6]. Поэтому обоснование параметров выемочной машины с вибрационным воздействием рабочего органа на массив горной породы, обеспечивающее снижение энергоёмкости выемочной машины, является актуальной научной задачей.

Целью работы является снижение энергоёмкости выемочной горной машины на основе оптимизации рациональных параметров рабочего органа с комбинированным воздействием исполнительного органа на очистной забой.

В исследовании реализуется идея повышения эффективности работы выемочной машины на основе применения технологии выемки угля в лавах узкими полосами при увеличении значений режимных параметров выемочной машины и снижении энергозатрат на разрушение пород с помощью вибрационных воздействий [7; 8]. Сверхзадачей исследований является установление корреляции между динамическими, энергетическими и режимными параметрами выемочной машины.

\section{Методы исследования}

Для выполнения поставленной цели использовались методы математического моделирования процессов взаимодействия рабочего органа агрегата с разрушаемым забоем и физическое моделирование процессов вибрационного резания горной породы [9; 10]. Этапы исследования включают в себя разработку математической модели функционирования рабочего органа машины и определение энергоемкости разрушения пород. Основу методов исследования составляет ретроспективный анализ и лабораторный эксперимент.

\section{Результаты исследований и обсуждение}

К недостаткам очистных комбайнов при отработке тонких и сверхтонких пластов относятся высокий удельный расход электроэнергии на выемку 1 т угля и ограниченная скорость подачи комбайна до $10-12$ м/мин.

Сравнение технологий выемки угля с использованием узкозахватного комбайна и струговой установки показывает, что каждое из устройств имеет свои достоинства и недостатки, однако для отработки пластов мощностью менее 1,8 м предпочтительнее является применение струговых установок, а при мощности свыше 2,3 м - установок комбайновой выемки (табл. 1) [11; 12].

Анализ современных схем технологий выемки угля показывает, что при применении высокоскоростных выемочных агрегатов, сочетающих в себе досто- инства очистных комбайнов и струговых установок, можно достичь существенного снижения удельной энергоёмкости процесса отделения минералов от забоя [13-15].

Выявлено, что новым направлением совершенствования горных машин на основе использования скоростной технологии выемки полезных ископаемых является комбинирование струговой и комбайновой технологии с дифференциацией режимных параметров выемочных машин с вибрационным воздействием рабочего органа на массив горной породы, обеспечивающее снижение энергоёмкости выемочной машины.

В ходе аналитических исследований определен алгоритм и получена дорожная карта исследования, включающая этапы:

- разработку модели функционирования рабочего органа выемочной машины;

- статистический анализ закона распределения скорости подачи выемочной машины и силы резания;

- установление зависимости удельных энергозатрат на извлечение горной породы от кинематических параметров рабочего органа;

- определение рациональных параметров вибрации;

- разработку методики расчёта параметров выемочной машины;

- исследование параметров функционирования рабочего органа выемочной машины;

- установление коррекции между динамическими, энергетическими и режимными параметрами выемочной машины.

- оценку сходимости результатов теоретических и экспериментальных исследований.

Разработанная нами математическая модель функционирования рабочего органа выемочной машины отличается тем, что она описывает комбинированное воздействие рабочего органа на забой с учётом вибрационных воздействий.

Результаты расчетов разработанной математической модели позволили получить следующие результаты:

- условием эффективного разрушения массива угля является такой режим работы, когда траектория скалывателя не опережает траекторию резца;

- суммарная мощность, затрачиваемая на отрыв горной породы, находится в параболической зависимости от скорости подачи выемочной машины, причём влияние наложения вибрационных воздействий на разрушаемый забой сказывается при скорости подачи более 10 м/мин;

- суммарная удельная энергоемкость разрушения забоя рабочим органом выемочной машины находится в параболической зависимости от ширины захвата выемочной машины, при этом минимальное значение удельной энергоёмкости с учётом наложений вибрационных воздействий на забой достигается при ширине захвата 0,35-0,4 м; 
- установлено, что зависимость периодичности скола целиков от скорости подачи имеет гиперболический характер, выполаживание происходит при скорости подачи 6-10 м/мин, а при скоростях свыше 10 м/мин происходит скол и снижается динамика работы рабочего органа;

- определено, что со снижением мощности на резание (ширины щели) смещается точка минимальной энергоемкости в сторону меньшего захвата;

- выявлено, что использование выемочных ком- байнов с рабочим органом, осуществляющим комбинированное разрушение массива, эффективнее при малых величинах захвата (менее 0,3 м);

- выявлено, что при разрушении (скалывании) отрезаемых дисками целиков с помощью клиновых устройств (конических шарошек) удельные энергозатраты обусловлены силами трения о целик при вращении диска рабочего органа и при перемещении его со скоростью подачи, а величины сил трения связаны с напряжениями в породе при ее скалывании [16; 17].

Таблица 1 / Table 1

Сравнение характеристик технологий выемки угля / Comparison of characteristics of coal mining technologies

\begin{tabular}{|c|c|}
\hline \multicolumn{2}{|c|}{ Технология выемки угля / Coal mining technology } \\
\hline $\begin{array}{c}\text { Узкозахватные комбайны } \\
\text { Narrow harvesters } \\
\text { Расход электроэнергии до } 0,8-1,2 \mathrm{\kappa BT} / \mathrm{T} \\
\text { Power consumption up to } 0.8-1.2 \mathrm{~kW} / \mathrm{t}\end{array}$ & $\begin{array}{c}\text { Быстроходная выемочная машина (БВМ) } \\
\text { Hidh speed excavation machine (HSEM) } \\
\text { Расход электроэнергии 0,25-0,4 кВт/т за счет отжима } \\
\text { пласта и перемещения на колесных парах вместо волочения } \\
\text { комбайна } \\
\text { Consumption of electricity 0,25-0,4 kW/t by squeezing the } \\
\text { reservoir and move the wheel set instead of a drawing of a food } \\
\text { processor }\end{array}$ \\
\hline $\begin{array}{c}\text { Излишнее измельчение угля шнеком комбайна. Низкая } \\
\text { погрузочная способность исполнительного органа } \\
\text { Excessive grinding of coal auger combine. Low load- } \\
\text { ing capacity of the Executive body }\end{array}$ & $\begin{array}{c}\text { Улучшение сортности угля достигается за счет фрезы с } \\
\text { параметрами крупного скола и оптимального измельчения } \\
\text { угля при погрузке скребковым конвейером } \\
\text { Improving the grade of coal is achieved by milling with the } \\
\text { parameters of coarse chipping and optimal grinding of coal } \\
\text { when loading with a scraper conveyor }\end{array}$ \\
\hline $\begin{array}{c}\text { Продолжительность и трудоемкость операций с } \\
\text { двухшнековым комбайном } \\
\text { The duration and complexity of operations with } \\
\text { a two-screw combine }\end{array}$ & $\begin{array}{c}\text { Снижение трудоемкости работ на концевых операциях в } \\
1,8-2,4 \text { раза } \\
\text { Reduction of labor intensity of works on end operations in } \\
1,8-2,4 \text { times }\end{array}$ \\
\hline $\begin{array}{l}\text { Ограничение скорости подачи комбайна } \\
\text { до } 10-12 \mathrm{~m} / \mathrm{Mин} \\
\text { Limiting the feed speed of the combine to } 10-12 \mathrm{~m} / \mathrm{min}\end{array}$ & $\begin{array}{c}\text { Дистанционное программное управление процессами } \\
\text { Remote a software process management }\end{array}$ \\
\hline $\begin{array}{c}\text { Образование между шнеками комбайнов трудно } \\
\text { проветриваемой зоны } \\
\text { Education between the augers of combines hard- } \\
\text { ventilated areas }\end{array}$ & $\begin{array}{c}\text { Компактные размеры не создают препятствий } \\
\text { проветриванию } \\
\text { Compact size does not interfere with ventilation }\end{array}$ \\
\hline $\begin{array}{c}\text { Нестабильность газовой динамики при } \\
\text { высокоинтенсивной выемке угля } \\
\text { Instability of gas dynamics in high-intensity coal } \\
\text { mining }\end{array}$ & $\begin{array}{c}\text { Улучшение показателей газового и вентиляционного режи- } \\
\text { мов на 20-30 \% при повышении нагрузки на очистной забой } \\
\text { по газовому фактору в 1,2-1,5 раза } \\
\text { Improvement of gas and ventilation conditions by } 20-30 \% \\
\text { with an increase in the load on the treatment face by the gas } \\
\text { factor by } 1.2-1.5 \text { times }\end{array}$ \\
\hline \multicolumn{2}{|l|}{ Струговые установки / Plough system } \\
\hline $\begin{array}{c}\text { Ограничение нагрузки на лаву с сопротивляемостью } \\
\text { угля резанию более } 240 \text { кН/м, со сложной } \\
\text { гипсометрией почвы, включением пород и мелко } \\
\text { амплитудными сбросами } \\
\text { Limiting the load on the lava with the resistance of } \\
\text { coal to cutting more than } 240 \mathrm{kN} / \mathrm{m} \text {, with complex soil } \\
\text { hypsometry, the inclusion of rocks and fine amplitude } \\
\text { discharges }\end{array}$ & $\begin{array}{l}\text { Применения фрезы с мощными тангенциальными резцами, } \\
\text { повышение мобильности БВМ, использование частотно- } \\
\text { регулируемого привода подачи, присечка фрезой почвы } \\
\text { (кровлю) } \\
\text { The use of cutters with powerful tangential cutters, increasing } \\
\text { the mobility of HSEM, the use of variable frequency drive feed, } \\
\text { cutting soil (roof) }\end{array}$ \\
\hline $\begin{array}{c}\text { Потери угля при переменной мощности пласта } \\
\text { вдоль лавы } \\
\text { Losses of coal at a variable bed thickness along } \\
\text { the lava }\end{array}$ & $\begin{array}{l}\text { Возможность реакции на изменение мощности пласта } \\
\text { The possibility of a reaction to the change in bed thickness }\end{array}$ \\
\hline
\end{tabular}


Экспериментальное подтверждение результатов теоретических исследований по определению рабочих и динамических параметров процесса и измерения нагрузки на исполнительный орган было получено на экспериментальном стенде, имитирующем вибрационное воздействие на разрушаемый массив. Цель исследования энергоемкости вибрационного воздействия рабочего органа - определение затрат энергии на отделение подрезанного опережающей щелью целика горной породы с тремя открытыми поверхностями, связанного с массивом пласта одной стороной.

На рис. 1 представлен породный блок после воздействия на него рабочего органа выемочной машины с наложением вибрационных воздействий на рабочий орган.

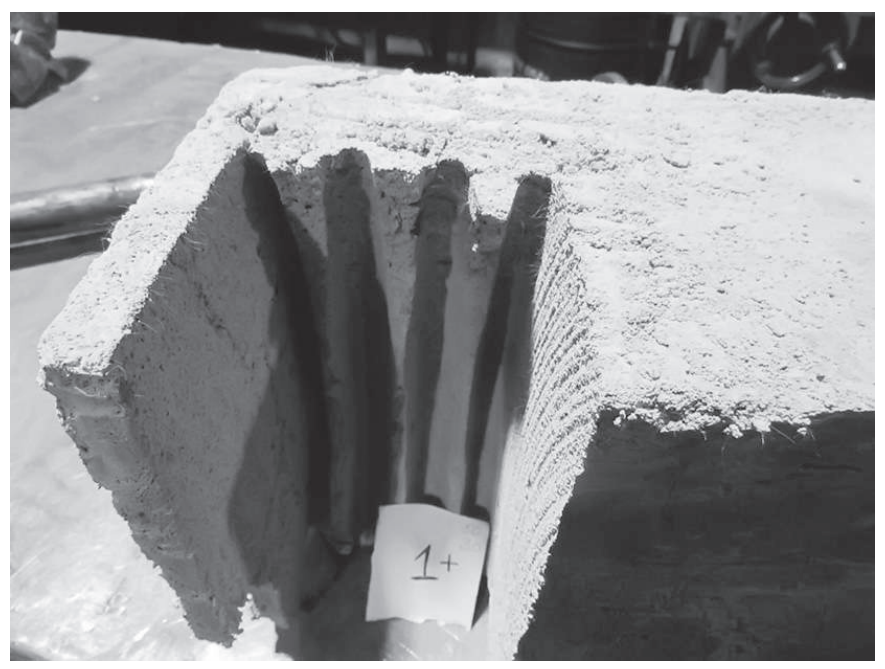

Puc. 1. Образеи горной породы после воздействия на него рабочего органа выемочной машины

Fig. 1. Rock sample after the working body impact of the excavation machine

Из рис. 1 видно, что зона 1 характеризуется полным скалыванием целика. В этой зоне осуществлялось комбинированное воздействие (резание плюс вибрации) $[18 ; 19]$. Установлено, что чем выше абсолютное значение мощности при отделении целика от массива и меньше время этого процесса, тем меньше величина энергии, затраченная на отделение целика.

Решающее влияние на энергоёмкость процесса отделения целика от массива горной породы оказывает частота вращения рабочего органа и вала вибровозбудителя, а также соотношение частот их вращения. На рис. 2 представлена зависимость расхода мощности и силы тока от времени при сонаправленном вращении и частоте вращения рабочего органа 30 Гц, частоте вращения вибровозбудителя 40 Гц, эксцентриситете 1,5 мм и подаче 7 мм/с.

Для минералов различной прочности важно направление вращения рабочего органа и вала вибровозбудителя. Сонаправленное вращение обоих валов уменьшает частоту колебаний рабочего органа и уве- личивает энергоемкость процесса. При встречном вращении валов мощность на валу вибровозбудителя больше, а частота воздействий рабочего органа на целик значительно больше, чем при сонаправленном вращении валов. Время воздействия рабочего органа на забой до полного отделения от него целика при встречном вращении валов меньше, чем при сонаправленном, что свидетельствует о меньшей энергоёмкости процесса.

Результаты экспериментальных исследований показали, что суммарная удельная энергоемкость разрушения забоя рабочим органом выемочной машины находится в параболической зависимости от ширины захвата выемочной машины, при этом минимальное значение удельной энергоёмкости с учётом наложения вибрационных воздействий на забой достигается при ширине захвата $0,35-0,4$ м. При отрыве удельная энергоемкость $(W)$ по сравнению с разрушением сплошным резанием снижается. При резании угля с $b_{\text {u }}=0,1$ м и $A=100 \mathrm{H} / \mathrm{Mм}, \sigma_{\text {сж }}=12 \mathrm{MПа}$, $\sigma_{\text {раст }}=0,38$ МПа она снижается от 0,54 до 0,29 кВт·ч/т, т. е. в 1,86 раза. При резании с той же шириной щели угля с $A=300 \mathrm{H} / \mathrm{мм}, \sigma_{\text {сж }}=26 \mathrm{MПа,} \sigma_{\text {раст }}=0,49$ МПа она снижается с 1,5 до 0,63 кВт·ч/т, т. е. в 2,4 раза. Основную долю составляют потери скалывающего элемента на трение. На эти потери существенно влияет скорость вращения скалывателя vск вместе с диском рабочего органа. С уменьшением или увеличением этой скорости мощность на трение изменяется, а при $v_{\text {ск }}=0$ равна нулю $\left(N_{\text {тр.отр }}=0\right)$, т. е. скалывающий элемент будет находиться в статическом положении. Поэтому в конструкции рабочего органа возможно применение статического скалывающего элемента, не связанного с вращающимся режущимся диском.

Основным объектом исследований в данной работе являлся рабочий орган выемочной машины. На основании проведённых теоретических и экспериментальных исследований функционирования рабочего органа выемочной машины для разрушения горных пород с различными физико-механическими свойствами было сконструировано и изготовлено три оригинальных варианта макетов рабочих органов и поданы заявки на изобретения. Один из таких вариантов опытно-промышленного образца рабочего органа выемочной машины показан на рис. 3.

В ходе проведения экспериментальных исследований функционирования опытно-промышленного образца рабочего органа выемочной машины были получены следующие результаты:

- мощность на резание шнекового рабочего органа больше мощности, расходуемой комбинированным рабочим органом выемочной машины. Так, при захвате рабочего органа 0,2 м и сопротивляемости резанию $A=100 \mathrm{H} /$ мм мощность на резание равна $\sim 140$ кВт, а на разрушение комбинированным рабо- 


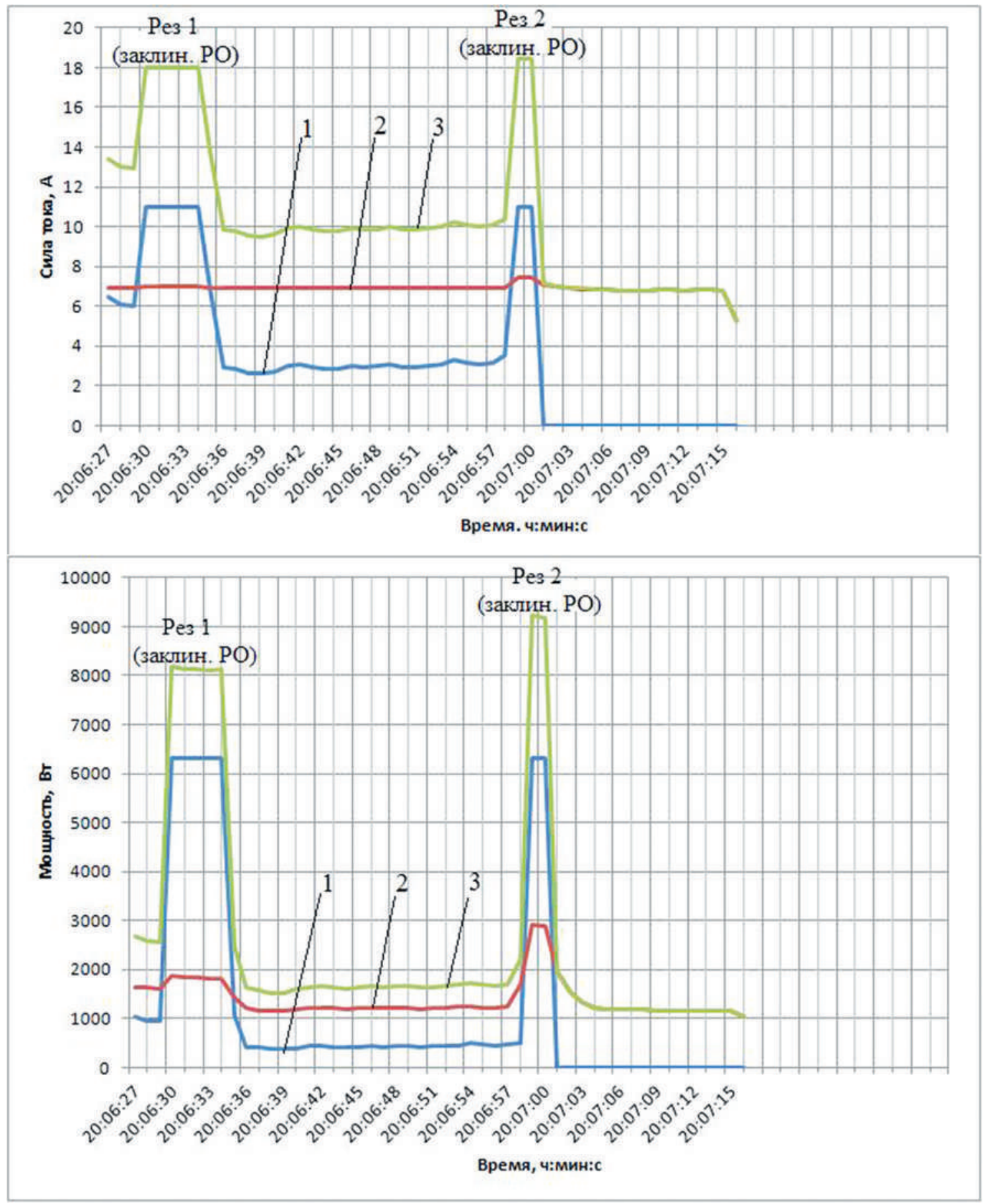

Pис. 2. Зависимости расхода мощңности и силь тока в рабочем режиме от времени:

1 - электродвигатель привода рабочего органа; 2 - электродвигатель привода вибровозбудителя; 3 - суммарная характеристика

Fig. 2. The power consumption and current force in working mode dependence on time: 1 - motor drive working body; 2 - motor drive vibration exciter; 3 - the total characteristics

чим органом выемочной машины $>80$ кВт при ширине щели $0,1 \mathrm{~m}$;

- удельные энергозатраты на отрыв целика находятся в квадратичной зависимости от величины отношения ширины целика к его высоте. При этом минимальные значения энергозатрат при выбранном значении $h$ находятся в диапазоне $b / h=(0,65 \ldots 0,85)$.

На экспериментальной кривой (рис. 4) минимум величины удельной энергоемкости смещён в сторону большего значения ширины захвата рабочего органа, вследствие наличия дефектов и трещин в структуре забоя и феномена отжима горной породы в забойном пространстве [20]. Числовые значения, отложенные по осям координат идентичны, что подтверждает сходимость результатов теоретических и экспериментальных исследований, которая при доверительной вероятности 0,93 составила $87 \%$.

Определение основных параметров выемочной машины выполнялось аналогично определению параметров его рабочего органа. Применялись слабые 


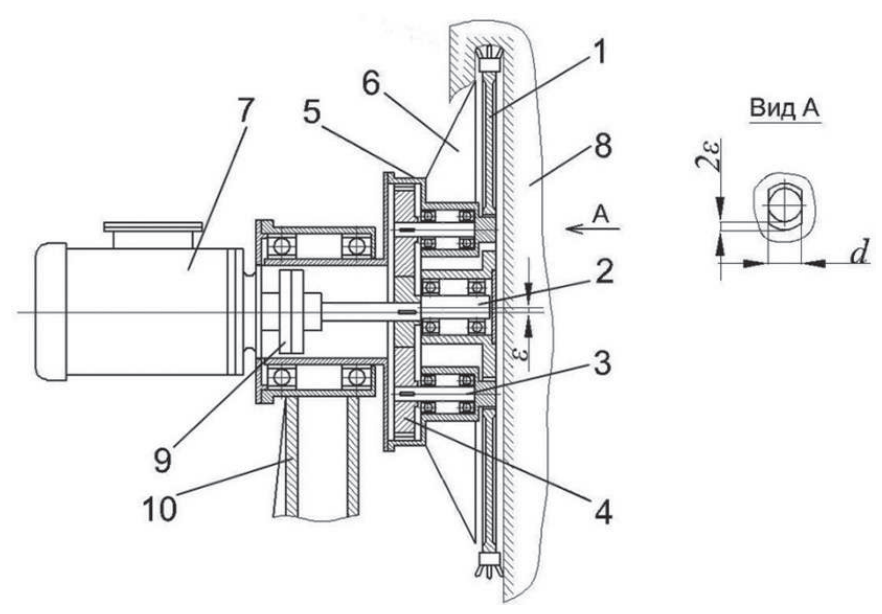

Pис. 3. Общиий вид опытно-промылиенного образияа рабочего органа выемочной машины:

1 - рабочий орган, 2 - эксиентрик, 3 - вал сателлита, 4 - сателлит, 5-водило, 6-скальватель, 7 - электродвигатель, 8-массив полезного ископаемого, 9 -муфта, 10 - опора рабочего органа

Fig. 3. General view of the experimental-industrial design of the working body of the excavating machine:

1 -actuator, 2 -cam, 3 - shaft pinion, 4-pinion, 5 -led, 6 - cleaver, 7 - motor, 8-array mineral, 9 - coupling, 10-working body support породы с сопротивляемостью резанию $A=100$ H/мм, временным сопротивлением одноосному сжатию $\sigma_{\text {сж }}=12$ МПа и временным сопротивлением растяжению $\sigma_{\text {pacm }}=0,38 \mathrm{MПа;} \mathrm{крепкие} \mathrm{породы} \mathrm{с} \mathrm{сопротивляе-}$ мостью резанию $A=300 \mathrm{H} /$ мм, временным сопротивлением одноосному сжатию $\sigma_{c ж}=26$ МПа и временным сопротивлением растяжению $\sigma_{\text {раст }}=0,49 \mathrm{MПа.}$ Режимы работы выемочной машины: скорость подачи $v_{n}=12 \mathrm{M} / \mathrm{мин,} \mathrm{скорость} \mathrm{резания} v_{p}=5,15 \mathrm{M} / \mathrm{c}$, резцы ИТ-2C.

Ранее было установлено, что со снижением мощности $N_{p e s}$, расходуемой на образование щели, интенсивное снижение мощности рабочего органа в зависимости от ширины захвата наблюдается при ширине захвата менее 0,3 м, а на энергоемкость отделения целиков $H_{w}$ влияют размеры их поперечного сечения $b$ и $h$ (рис. 4 ) и их соотношение $b / h$.

В расчётах была принята глубина щели целика $h=0,06$ м, а толщина целика изменялась в диапазоне $b=0,024 \ldots 0,06$ м. Параметры рабочего органа принимались, исходя из условия обеспечения заданной производительности при оптимальной сортности и минимальной энергоемкости разрушения (табл. 2).

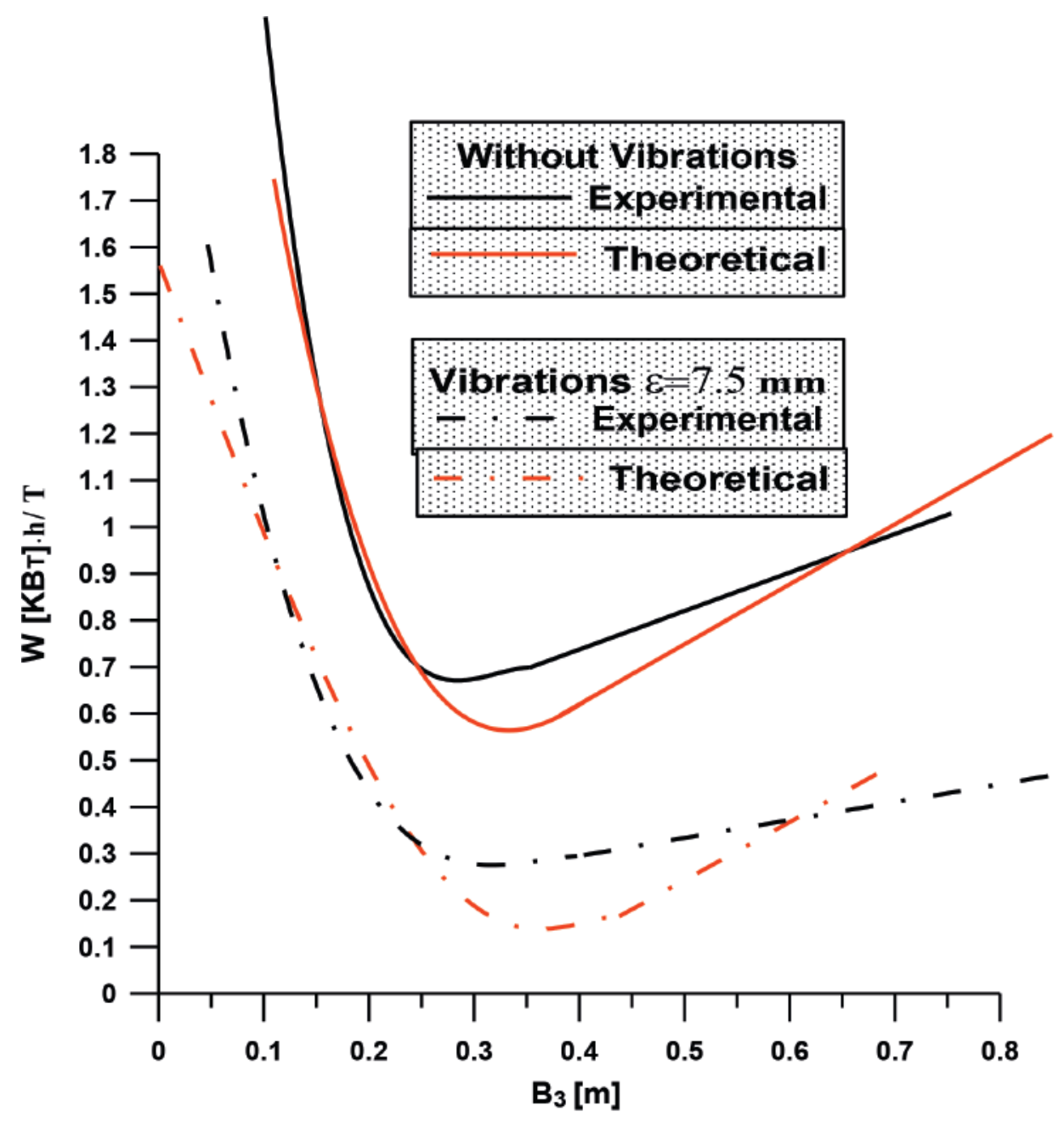

Pис. 4. Сравнение теоретических и экспериментальных зависимостей удельной энергоемкости от ширинь захвата рабочего органа

Fig. 4. Comparison of theoretical and experimental dependences of specific energy intensity on the width of the working body 
Данные к расчету параметров выемочной машины

Таблица 2 / Table 2

Data to the calculation of the parameters of the dredging machine

\begin{tabular}{|c|c|c|c|}
\hline $\begin{array}{l}\text { Показатель } \\
\text { Indicator }\end{array}$ & $\begin{array}{c}\text { Ед. изм. } \\
\text { Measur- } \\
\text { ing unit }\end{array}$ & $\begin{array}{c}\text { Символ } \\
\text { Symbol }\end{array}$ & $\begin{array}{l}\text { Значение } \\
\text { Value }\end{array}$ \\
\hline $\begin{array}{l}\text { Расчетная мощность разрушаемого пласта } \\
\text { Design capacity of the fractured formation }\end{array}$ & $\mathrm{M}$ & $\mathrm{H}_{\mathrm{p}}$ & 1,15 \\
\hline $\begin{array}{l}\text { Расчетная сопротивляемость пласта резанию в неотжатой зоне очистного забоя } \\
\text { The calculated resistance of the layer to cutting in uncompressed zone of the clearing face }\end{array}$ & $\mathrm{H} / \mathrm{MM}$ & $A_{p}$ & 240 \\
\hline $\begin{array}{l}\text { Показатель степени хрупкости пласта при резании } \\
\text { Indicator of the degree of brittleness of the formation during cutting }\end{array}$ & - & $\mathrm{E}$ & 1,65 \\
\hline $\begin{array}{l}\text { Плотность угля } \\
\text { The density of coal }\end{array}$ & $\mathrm{T} / \mathrm{M}^{3}$ & $\gamma$ & 1,4 \\
\hline $\begin{array}{l}\text { Расчетная производительность комбайна } \\
\text { Design capacity of the combine }\end{array}$ & $\begin{array}{l}\mathrm{T} / \mathrm{Mин} \\
\mathrm{t} / \mathrm{min}\end{array}$ & $\mathrm{Q}_{3}$ & 9,5 \\
\hline $\begin{array}{l}\text { Ширина захвата } \\
\text { Width }\end{array}$ & $\mathrm{M}$ & $\mathrm{B}_{3}$ & 0,31 \\
\hline $\begin{array}{l}\text { Диаметр исполнительного органа } \\
\text { The diameter of the operating body }\end{array}$ & $\mathrm{M}$ & $\mathrm{D}$ & 0,9 \\
\hline $\begin{array}{l}\text { Показатель способности угля к измельчению } \\
\text { Indicator of the ability of coal to grind }\end{array}$ & - & $\mathrm{T}_{\text {и }}$ & 0,75 \\
\hline $\begin{array}{l}\text { Тип резцов } \\
\text { Type of cutters }\end{array}$ & \multicolumn{3}{|c|}{$\begin{array}{c}\text { Тангенциальный РШ35-95/16.М2 } \\
\text { Tangential РШ35-95/16.M2 }\end{array}$} \\
\hline $\begin{array}{l}\text { Конструктивная ширина режущей части резца } \\
\text { Constructive width of the cutting part of the cutter }\end{array}$ & $\mathrm{cM}$ & $\mathrm{B}_{\mathrm{K}}$ & 1,6 \\
\hline $\begin{array}{l}\text { Конструктивный вылет резца } \\
\text { Constructive cutter departure }\end{array}$ & $\mathrm{cm}$ & $1_{\mathrm{k}}$ & 10,2 \\
\hline $\begin{array}{l}\text { Длина хвостовика } \\
\text { Shank length }\end{array}$ & $\mathrm{cm}$ & $1_{\mathrm{xв}}$ & 6,8 \\
\hline $\begin{array}{l}\text { Длина резца } \\
\text { The length of the cutter }\end{array}$ & $\mathrm{cm}$ & 1 & 19,5 \\
\hline $\begin{array}{l}\text { Угол установки резца к поверхности резания } \\
\text { The angle of the cutter to the cutting surface }\end{array}$ & $\begin{array}{c}\text { град } \\
\text { degree }\end{array}$ & $\Theta$ & 45 \\
\hline $\begin{array}{l}\text { Эксцентриситет } \\
\text { Eccentricity }\end{array}$ & MM & $\varepsilon$ & 7,5 \\
\hline $\begin{array}{l}\text { Относительная частота вращений валов рабочего органа и вибровозбудителя } \\
\text { The relative speed of the shafts of the working body and vibration exciter }\end{array}$ & $\begin{array}{l}\text { об/мин } \\
\mathrm{rot} / \mathrm{min}\end{array}$ & W & 1200 \\
\hline
\end{tabular}

Расчётная схема взаимодействия дискового режущего органа со скалывателем с целиком горной породы приведена на рис. 5.

Расстояние от точки контакта целика со скалывателем до его основания:

$$
h=\left(R_{p}-R_{\text {Д }}\right) \operatorname{tg} \beta+\frac{b_{p}}{2}\left(\frac{2 \cos \beta^{2}-1}{\cos \beta}\right)-\left(\frac{b_{\text {Д }}}{2}+k\right),
$$

где $R_{p}$ - расстояние от оси вращения рабочего органа до оси вращения скалывающего элемента, м;

$R_{д}^{p}$ - расстояние от оси вращения рабочего органа до оси вращения скалывающего элемента, м;

$\beta$ - угол наклона резца, град;

$b_{p}$ - ширина резца, м;

$b_{\text {д }}^{p}$ - ширина диска, м;

$k$ - расстояние от основания скалывателя до торцевой поверхности диска, м.

Глубина щели:

$$
h_{u}=R_{p}-\left(R_{c}+\frac{d_{c}}{2}\right)+\left[\left(R_{p}-R_{g}\right) \operatorname{tg} \beta+\frac{b_{p}}{2}\left(\frac{2 \cos ^{2} \beta-1}{\cos \beta}\right)-\left(\frac{b_{g}}{2}+k\right)\right] \operatorname{ctg} \alpha,
$$

где $R_{c}$ - расстояние от оси вращения рабочего органа до вершины резца, м; 


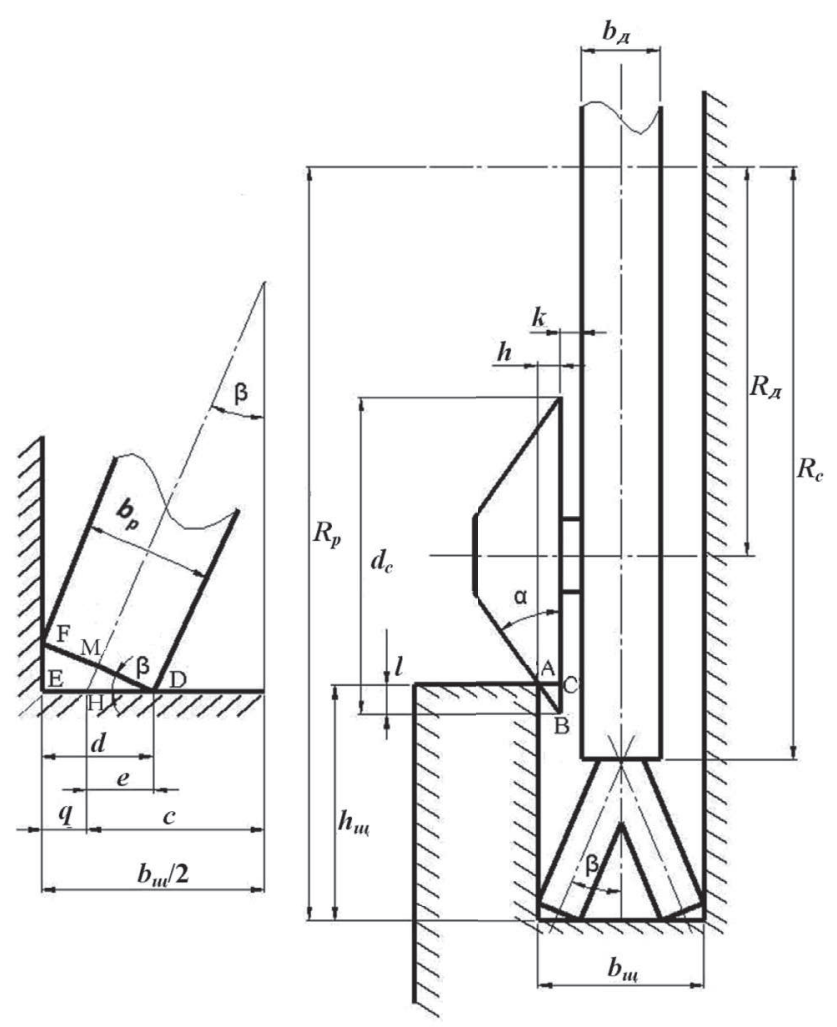

Pис. 5. Расчётная схема взаимодействия дискового режущзего органа со скалывателем с изеликом горной породы: а-увеличенная в масштабе схема взаимодействия резца с забоем; б - общий вид

Fig. 5. The calculated scheme of interaction of the disk cutting body with a cleaver with the whole rock: $a$-increased scale scheme of interaction of the cutter with the face;

$$
b \text { - general view }
$$

$d_{c}$ - диаметр скалывающего элемента, м;

$\alpha$ - угол между образующей скалывателя и его основанием, град.

Период скола горной породы:

$$
T_{c \kappa}=0,6 \frac{R_{p}-\left(R_{c}+\frac{d_{c}}{2}\right)+\left[\left(R_{p}-R_{g}\right) \operatorname{tg} \beta+\frac{b_{p}}{2}\left(\frac{2 \cos ^{2} \beta-1}{\cos \beta}\right)-\left(\frac{b_{g}}{2}+k\right)\right] \operatorname{ctg} \alpha}{V_{n}},
$$

где $V_{n}-$ скорость подачи, м/мин.

Ширина щели

$$
\frac{b_{u}}{2}=\left(R_{p}-R_{g}\right) \operatorname{tg} \beta+\frac{b_{p}}{2}\left(\frac{2 \cos ^{2} \beta-1}{\cos \beta}\right) .
$$

Критическая скорость подачи выемочной машины, м/мин:

$$
V_{n . \kappa p}=R_{p}-\left(R_{c}+\frac{d_{c}}{2}\right) \frac{\pi n}{30(2 \pi-\alpha)}=L \frac{\pi n}{30(2 \pi-\alpha)},
$$

где $n$ - число оборотов рабочего органа, об/мин;

$L$ - расстояние от точки контакта целика со скалывающим элементом до вершины основания скалывающего элемента, м.

Усилие, необходимое для отрыва целика, Н:

$$
P=\frac{\sigma_{o m p} \pi^{2} D b_{u}^{2}}{24 h_{u}}
$$

где $\sigma_{\text {отр }}=\sigma_{\text {раст }}-$ временное сопротивление угля растяжению, $\mathrm{H} / \mathrm{M}^{2}$;

$b_{u}$ - ширина целика, м;

$h_{u}$ - глубина щели, м. 
Сила трения скалывающего элемента о целик, Н:

$$
F_{m p}=\frac{\sigma_{o m p} \pi^{2} D b_{u}^{2} f_{m p}}{24 h_{u}},
$$

где $f_{m p}$ - коэффициент трения металла по породе.

Усилие на внедрение скалывающего элемента, Н:

$$
F_{n}=P \operatorname{tg} \alpha=\frac{\sigma_{o m p} \pi^{2} b_{u}^{2} \operatorname{tg} \alpha D}{24 h_{u}} .
$$

Мощность, расходуемая на трение скалывающего элемента

$$
N_{\text {mp.omp }}=\frac{F_{m p} V_{c \kappa} V_{n}}{2 \cdot 1000 \cdot n h_{u}},
$$

где $V_{c \kappa}$ - скорость точки контакта скалывающего элемента с целиком, м/с;

$V_{n}^{c \kappa}-$ скорость подачи, м/мин.

Мощность, расходуемая на подачу

$$
N_{n . o m p}=\frac{\sigma_{o m p} \pi^{2} D b_{u}^{2} \operatorname{tg} \alpha V_{n}^{2}}{2 \cdot 1000 \cdot 24 \cdot 60 \cdot n h_{u}^{2}}
$$

Мощность, затрачиваемая на отрыв целика, м:

$$
N_{\text {omp }}=N_{\text {mp.omp }}+N_{\text {n.omp }}=\frac{\sigma_{\text {omp }} \pi^{2} D b_{u}^{2} V_{n}}{2 \cdot 24 \cdot 1000 \cdot n h_{u}^{2}}\left(f_{m p} V_{c \kappa}+\frac{V_{n}}{60} \operatorname{tg} \alpha\right) .
$$

Скорость точки контакта скалывающего элемента с целиком, м/с:

$$
V_{c \kappa}=\frac{\pi R_{c \kappa} n}{30}-\frac{\pi\left(R_{p}-h_{u}\right) n}{30} .
$$

Производительность по разрушению целиков, т/ч:

$$
Q=\frac{60 b_{u} D V_{n} \gamma}{10^{4}}=\frac{6 b_{u} D V_{n} \gamma}{10^{3}} .
$$

Удельная энергоемкость процесса отрыва целика, кВт·ч/т:

$$
W=\frac{\sigma_{\text {omp }} \pi^{2} b_{u}}{288 \cdot n h_{u}^{2} \gamma}\left(f_{m p} V_{c \kappa}+\frac{V_{n}}{60} \operatorname{tg} \alpha\right) .
$$

Удельная энергоёмкость разрушения массива, кВт·ч/м²:

$$
W_{\Sigma}=\frac{N_{\Sigma}}{Q}=\frac{10^{3}\left[\frac{\sigma_{o m p} \pi^{2} D V_{n}}{2 \cdot 24 \cdot 1000 \cdot n h_{u j}^{2}}\left(f_{m p} V_{c \kappa}+\frac{V_{n}}{60} \operatorname{tg} \alpha\right)\left(B_{3}-b_{u \mu}\right)^{2}+N_{p e 3}\right]}{6 B_{3} D V_{n} \gamma},
$$

где $N_{\text {рез }}$ - мощность, потребляемая режущим диском, кВт.

Оптимальная ширина захвата, м:

$$
B_{o n m}=\sqrt{b_{u}^{2}+\frac{2 \cdot 24 \cdot 1000 \cdot n h_{u \mu}^{2} N_{p e 3}}{\sigma_{o m p} \pi^{2} D V_{n}\left(f_{m p} V_{c k}+\frac{V_{n}}{60} \operatorname{tg} \alpha\right)}}
$$

Суммарная сила резания:

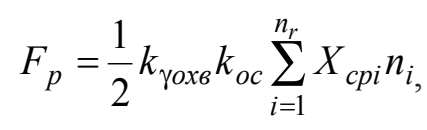

где $k_{\text {үохь }}$ коэффициент влияния угла охвата рабочего органа с разрушаемой пачкой угля на среднюю силу резания;

$k_{\text {ос }}$ - коэффициент ослабления массива угля, учитывающий ослабление угольного массива, опережающего рабочий орган, направление вращения рабочего органа, направление резания относительно напластования;

$X_{c p i}$ - средняя сила резания на резце, $\mathrm{H}$;

$n_{i}$ - число резцов в группе, одновременно разрушающих забой. 
Суммарная мощность резания, кВт

$$
N_{\Sigma}=\frac{\sigma_{o m p} \pi^{2} D V_{n}}{2 \cdot 24 \cdot 1000 \cdot n h_{u}^{2}}\left(f_{m p} V_{c \kappa}+\frac{V_{n}}{60} \operatorname{tg} \alpha\right) \times\left(\sqrt{b_{u}^{2}+\frac{2 \cdot 24 \cdot 1000 \cdot n h_{u s}^{2} N_{p e s}}{\sigma_{o m p} \pi^{2} D V_{n}\left(f_{m p} V_{c \kappa}+\frac{V_{n}}{60} \operatorname{tg} \alpha\right)}}-b_{u}\right)^{2}+N_{p e s} .
$$

Максимальная толщина стружки для забойных резцов определяется исходя из значения радиального вылета резца, м:

$$
h_{\max }=\frac{l_{p}}{k_{l}},
$$

где $l_{p}=l_{k} \cdot \sin \theta-$ радиальный вылет резца;

$k_{i}^{p}$ - коэффициент вылета тангенциального резца.

Критическая частота вращения фрезы $n_{\text {об.кp }}$ из условия ее центробежной разгрузки, об/мин:

$$
n_{\text {об.кр }}=42,3 D_{\min }^{-0,5} \text {. }
$$

Оптимальная ширина стружки для забойных резцов, м:

$$
t_{\text {onm.cp }}=\left(\frac{0,5 h_{c p}}{0,5 h_{c p}+4,5}+0,7 h_{c p}\right) \frac{1,47 E}{E+1,2}+b_{\kappa},
$$

где $h_{c p}$ - средняя глубина резания, м.

Толщина стружки, м:

$$
t_{c p}=0,85 t_{\text {onm.cp }},
$$

где $t_{c p}$ - средняя оптимальная ширина стружки для забойных резцов, м.

Вынимаемая площадь среза:

Ширина захвата кутковой части:

$$
S_{c p}=h_{c p} t_{c p}
$$

$$
B_{3 . \kappa}=\sum_{i=1}^{n_{\pi . \kappa}} t_{k . i}
$$

с шагами резания $t_{k 1}=0,03 \mathrm{~m} ; t_{k 2}=0,065 \mathrm{м}$.

Углы установки резцов к направлению подачи $\beta_{i}$ (град.) в линиях резания кутковой части фрезы:

$$
\beta_{1}=\arcsin \frac{B_{3 . k}-\sum_{i=1}^{i_{\text {n.k.k }}} t_{k_{i}}}{l \sin \theta} .
$$

Ширина захвата забойной части фрезы $B_{3.3}$ определяется условием:

$$
B_{3.3}=\sum_{i=1}^{n_{n .3}} t_{3 . i}
$$

Число линий резания в забойной части:

$$
n_{\text {л.3 }}=\frac{\left(100 B_{3}-B_{3 . K}\right)}{t_{\text {onm.cp }}} .
$$

Крайний с завальной стороны забойный шаг резания $t_{3, n:}$

Последующие шаги резания забойной части $t_{3, t}$

$$
t_{3 . n}=1,15 t_{\text {onm.cp }} .
$$

$$
t_{3.2}=\left(t_{3 . n}-t_{3.1}\right) \frac{2-1}{n_{\pi .3}-1}+t_{3.1}
$$

Ширина захвата кутковой части фрезы $B_{3.3}=\sum_{i=1}^{n_{n .3}} t_{3 . i}$ с шагами резания $t_{3.1}=6 \mathrm{~cm} ; t_{3.2}=7,5 \mathrm{~cm}, t_{3.3}=8,5$ см. Условие обеспечения крупного скола для полученных забойных шагов резания соблюдается:

4,6 см $<6 ; 7,5 ; 8,5$ см $\leq 9,5$ см. 


\section{Заключение}

1. Обосновано направление снижения энергоёмкости выемочной горной машины с комбинированным воздействием на очистной забой.

2. Получена математическая модель функционирования рабочего органа выемочной горной машины исходя из обеспечения производительности и минимальной энергоемкости разрушения минералов. Показано, что вибрационное резание минералов эффективно, если амплитуда колебаний рабочего инструмента больше отделяемой режущим инструментом толщины стружки.

3. Установлено, что мощность, затрачиваемая на отрыв горной породы, находится в параболической зависимости от скорости подачи выемочной машины, наиболее существенно при скорости подачи более 10 м/мин. При этом зависимость периодичности скола целиков от скорости подачи имеет гиперболический характер с выполаживанием при скорости подачи $6-10$ м/мин.

4. Определено, что энергоемкость разрушения забоя рабочим органом выемочной машины зависит от ширины захвата выемочной машины, а минимальное значение удельной энергоёмкости с учётом вибрационных воздействий на забой достигается при ширине захвата $0,35-0,4$ м.

5. Параметры вибровозбудителей радиально направленных колебаний рабочего органа рекомендованы к использованию при разработке конструкторской документации выемочной машины для использования при добыче минерального сырья и проходке горных выработок в горнодобывающей отрасли и смежных отраслях народного хозяйства.

\section{$\overline{Л И Т Е Р А Т У Р А: ~}$}

1. Голик В.И., Разоренов Ю.И., Каргинов К.Г. Основа устойчивого развития РСО-Алания - горнодобывающая отрасль // Устойчивое развитие горных территорий. Владикавказ. 2017. N (32). С.163-172.

2. Хетагуров В.Н., Каменецкий Е.С., Минасян Д.Г., Гегелашвили М.В. Исследование движения измельчаемого материала в центробежной мельнице вертикального типа при установке в ее рабочем пространстве коаксиального кольца // Устойчивое развитие горных территорий. Владикавказ. 2017. N. С. 286-291.

3. Ahlbrecht T., Schilder R. Bohrarbeiten für Gefrierschächte in Russland - Bergwerk Ust Jaiwa // Mining Report. Glückauf. 2013. Vol. 149. Iss. 2. Pp. 80-87.

4. Su O., Akcin N.A. Numerical simulation of rock cutting using the discrete element method // International Journal of Rock Mechanics and Mining Sciences. 2011. Vol. 48. No. 3. Pp. 434-442.

5. Zich A., Linnik Yu.N., Linnik V.Yu. Verlangerung der Betriebsdauer von Meiselhalterungen an schneidenden Kohlegewinnugsmaschinen // Mining report. Gluckauf. No 153. 2017. Рp. 474-479.

6. Белюшин Д.В., Лагунова Ю.А. Анализ экспериментальных данных ударного взаимодействия рабочих поверхностей вибромашин с горной породой // Горный журнал. Екатеринбург. 2017. N6. C 79-85.

7. Golik V.I., Dmitrak Yu.V. Parameters of solidifying mixtures transporting at underground ore mining // E3S Web of Conferences The Second International Innovative Mining Symposium. 2017.

8. Golik V.I., Dmitrak Yu.V. Parameters of transportation of tailings of metals lixiviating // E3S Web of Conferences The Second International Innovative Mining Symposium. 2017.

9. Волкова Л.П., Костин В.Н., Панкрушин П.Ю. Концептуальная модель базы данных САПР струговых агрегатов и установок // Горный информационно-аналитический бюллетень. 2016. N7. C.57-62.

10. Волкова Л.П., Костин В.Н., Панкрушин П.Ю. Разработка алгоритма сценария для САПР струговых агрега-

тов и установок // Горный информационно-аналитический бюллетень. 2016. N3. С.123-128.

11. Mendyka P., Kotwica K., Stopka G. Innovative Roadheader // Mining Head With Assymetrical Disc Tools. 2016. Pp. 489-496.

12. Skryabin R.M., Timofeev N.G. Development of an innovative shneko-heat-sink boring shell for drilling of shurfowells in the conditions of a kriolitozona // Eurasian mining. 2016. N 1. Pp. 33-36.

13. Вержанский П.М., Маслов М.И. Исследование энергоемкости вибрационного воздействия рабочего органа при разрушении забоя резанием // Горный информационно-аналитический бюллетень. 2015. N5. C.195-198.

14. Ушаков Л.С., Каманин Ю.Н., Климов В.Е. Решение задачи оптимизации процесса разрушения минерального массива планетарным ударно-скалывающим исполнительным органом технологической машины // Горный информационно-аналитический бюллетень. 2018. N1. C.103-108.

15. Фащиленко В.Н., Решетняк С.Н. Энергоэффективный резонансный режим электромеханических систем органов резания горных машин на базе современных структур управления // Горное оборудование и электромеханика. 2016. N 4. С. 41-45.

16. Лемешко М.А. Элементы теории адаптивного взаимодействия режущего инструмента с разрушаемым материалом // М.А. Лемешко / Механизация, автоматизация и электрификация горного и строительного производств, сервис технологических машин и оборудования: Сб. науч. тр. ЮРГТУ: «Набла», 2005. С. 37-41.

17. Жабин А.Б., Поляков А.В., Ковалева Т.В., Аверин Е.А. О расчетной схеме для определения устойчивости проходческого комбайна // Горное оборудование и электромеханика. 2018. N 2. C. 46-49.

18. Жабин А.Б., Чеботарев П.Н., Лавит И.М., Поляков А.В. Методика определения нагруженности резцов и расходуемой мощности при разрушении угля и их расчет для проходческого комбайна // Тул ГУ, 2017. N3. С. 135. 
19. Kuidong Gao, Changlong Du, Jianghui Dong, Qingliang Zeng. Influence of the Drum Position Parameters and the Ranging Arm Thickness on the Coal Loading Performance // Minerals. 2015. Vol. 5. Pp. 723-736.

20. Дмитрак Ю.В., Выскребенец А.С., Тарасов М.А. Определение энергетических параметров рабочего ор- гана выемочной машины при комбинированном способе разрушения массива горной породы // Сборник научных работ преподавателей и аспирантов СКГМИ (ГТУ): Горный информационно-аналитический бюллетень. 2018. N 4 (специальный выпуск 12). М.: Горная книга. С. 28-38.

\section{СВЕДЕНИЯ ОБ АВТОРАХ / Information about authors:}

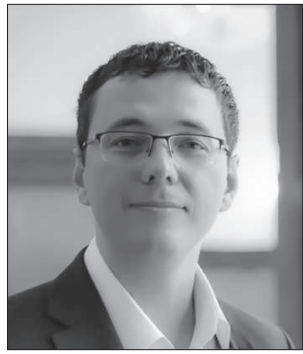

ТАРАСОВ Михаил Анатольевич - Генеральный директор АО «Центральный проектно-технологический институт», 115409 , Москва, Россия.

Тел.: (495) 988-82-82, доб. 7680; +7(917)559-32-18.

E-mail: MiAnTarasov@rosatom.ru.

Michail A. TARASOV - General Director of Ltd "Central Design and Technological Institute" ("CDTI"), 115409, Moscow, Russia.

Ph.: +7 (495) 988-82-82, ext. $7680 ;+7$ (917)559-32-18

E-mail:MiAnTarasov@rosatom.ru.

\section{MODELING OF OPERATING PARAMETERS OF MINING MACHINES WITH VIBRATION ON THE ROCKS \\ 'TARASOV M. A. \\ ${ }^{1}$ Ltd "Central Design and Technological Institute "("CDTI"), 115409, Moscow, Russia}

\section{DOI: $10.21177 / 1998-4502-2019-11-1-85-97$}

One of the basic industries development aspects is to increase the completeness of minerals extraction from the subsoil in the extraction of coal from thin and ultrathin layers. At the same time, the creation of modern efficient mining equipment for the development of lowpower coal seams is becoming one of the most important problems of coal production. The solution to this problem is possible by combining plow and combine technology with the differentiation of operating parameters of the excavators.

In the present work, the idea of improving the efficiency of the dredging machine based on the use of technology of coal extraction in lava by vibration. The stages of the research included the development of a mathematical model of the functioning of the working body of the machine and determine the energy intensity of the destruction of rocks.

It was found that the reduction in the specific energy intensity of the process of separation of minerals from the face can be achieved through the use of units that combine the advantages of treatment combines and plow plants. It is determined that the condition for the effective destruction of the coal mass is a mode of operation when the trajectory of the cleaver is not ahead of the path of the cutter.

Working and dynamic parameters of the process and measurement of the load on the Executive body were determined at the experimental stand simulating the vibration effect on the array:

the total power spent on the rock separation is in parabolic dependence on the feed rate of the excavation machine, and the effect of applying vibration effects on the destroyed face begins to affect significantly at a feed rate of more than $10 \mathrm{~m} / \mathrm{min}$; specific energy consumption for the separation of the whole are in quadratic dependence on the value of the ratio of the width of the whole to its height. The parameters of the working body are taken on the basis of the condition of ensuring a given performance at optimal grade and minimum energy consumption of destruction;

vibration cutting of the working body of the dredging machine is effective if the oscillation amplitude of the working tool is greater than the maximum chip thickness separated by the cutting tool.

The adequacy of the proposed mathematical model of the working body of the excavation machine is confirmed by bench studies of the efficiency of vibration cutting of minerals.

Parameters of vibration exciters of radially directed vibrations of the working body are recommended for use in the development of design documentation of the excavation machine for use in the extraction of mineral raw materials and mining in the mining industry and related sectors of the economy.

Keywords: excavation machine, energy intensity, combined impact, working body, mathematical model, vibration cutting, raw material extraction, excavation.

References:

1. Golik V. I., Razorenov Yu. I., Karginov K. G. Basis of sustainable development of RSO-Alania - mining industry. Sustainable Development of Mountain Territortes. Vladikavkaz. 2017. no.2 (32). pp. 163-172.

2. Khetagurov V. N., Kamenetsky E. S., Minasyan D. G., Gegelashvili M. V. Investigation of the motion of the mill material in a centrifugal mill of vertical type when 
installing a coaxial ring in its working space. Sustainable Development of Mountain Territortes. Vladikavkaz. 2017. no. 4. pp. $286-291$.

3. Ahlbrecht T.,Schilder R. Bohrarbeiten für Gefrierschächte in Russland - BergwerkUstJaiwa . Mining Report. Glückauf. 2013, Vol. 149, Iss. 2, pp. 80-87.

4. Su O., Akcin N.A. Numerical simulation of rock cutting using the discrete element method. International Journal of Rock Mechanics and Mining Sciences. 2011, Vol. 48, no. 3, pp. 434-442.

5. Zich A., Linnik Yu.N., Linnik V.Yu. Verlangerung der Betriebsdauer von MeiselhalterungenanschneidendenKohlegewinnugsmaschinen. Mining report. Gluckauf. no 153, 2017, pp. $474-479$.

6. Belusina V. D., Lagunova, Yu. a. Analysis of experimental data of shock interaction between the working surfaces of the vibrators with rock. Mining journal, Yekaterinburg, 2017, no. 6, pp. $79-85$.

7. Golik V.I., Dmitrak Yu.V. Parameters of solidifying mixtures transporting at underground ore mining. E3S Web of Conferences The Second International Innovative Mining Symposium. 2017.

8. Golik V.I., Dmitrak Yu.V. Parameters of transportation of tailings of metals lixiviating. E3S Web of Conferences The Second International Innovative Mining Symposium. 2017.

9. Volkova L. P., Kostin, V. N. Pankroushin P. Y. Conceptual model database CAD plow units and systems. Mining informationanalytical Bulletin. 2016, no. 7, pp. 57 - 62.

10. Volkova L. P., Kostin, V. N., Pankroushin P. Y. Development of an algorithm of the scenario for CAD plow units and systems. Mining informationanalytical Bulletin, 2016, no. 3, pp. $123-128$.

11. Mendyka P., Kotwica K., Stopka G. Innovative Roadheader. Mining Head With Assymetrical Disc Tools, 2016, pp. $489-496$.

12. Skryabin R.M., Timofeev N.G. Development of an innovative shnekoheatsink boring shell for drilling of surfwells in the conditions of permafrost. Eurasian mining. 2016. no. 1 , pp. $33-36$.

13. Verzhansky p. M., Maslov M. I. Study of the energy intensity of the vibration impact of the working body in the destruction of the face by cutting. Mining Information and Analytical Bulletin. 2015, no. 5, pp. 195 - 198.

14. Ushakov L. S., Kamanin Yu. N., Klimov V. E. The solution of the problem of optimization of the process of destruction of the mineral massif by the planetary shockchipping Executive body of the technological machine. Minning Information Analytical Bulletin. 2018, no. 1, pp. 103 - 108.

15. Vasilenko, V. N., Reshetnyak S. N. Energy efficient resonant mode of Electromechanical systems of bodies cutting mining machines on the basis of modern management structures. Mining machinery and electro mechanics. 2016, no. 4 , pp. $41-45$.

16. Lemeshko M. A. Elements of the theory of adaptive interaction of the cutting tool with the destroyed material. Mechanization, Automation and Electrification of Mining and Construction Industries, Service of Technological Machines and Equipment: Collection of proceedings "Nabla", SRSTU, 2005, pp. $37-41$.

17. Zhabin A. B., Polyakov A.V., Kovaleva T. V., Averin E. A. On the design scheme for determining the stability of the tunneling machine. Mining equipment and electro-mechanics. 2018, no. 2, pp. $46-49$.

18. Zhabin A. B., Chebotarev P. N., Lavit I. M., Polyakov A.V. The method of determining the load of cutters and the consumed power in the destruction of coal and their calculation for the tunneling combine. Tula State University, 2017, no. 3 , pp. 135 .

19. Kuidong Gao, Changlong Du, Jianghui Dong, Qingliang Zeng. Influence of the Drum Position Parameters and the Ranging Arm Thickness on the Coal Loading Performance. Minerals. 2015, Vol. 5, pp. $723-736$.

20. Dmitrak Yu. V., Vyskrebenets A. S., Tarasov M. A. Determination of the energy parameters of the working body of the excavation machine with a combined method of destruction of rock mass. Collection of Scientific Works of Teachers and Graduate Students of SKGMI (GTU): Mining Information and Analytical Bulletin, 2018, no. 4 (special issue 12), Moscow: Mountain book. Pp. 28 - 38.

Article received 03.10.2018. 
'Цидаев Б. С. 2Логачев А.B., ЗГолик В.И.*

\section{ПОВЫШЕНИЕ РЕНТАБЕЛЬНОСТИ ДОБЫЧИ НЕФТИ ПУТЕМ ДИВЕРСИФИКАЦИИ ТЕХНОЛОГИЙ}

\section{УДК: 504.55.054:622(470.6)} DOI: 10.21177/1998-4502-201911-1-98-104

Дано обоснование возможности повысить рентабельность добычи углеводородного сырья в условиях депрессивного горного региона. Приведены результаты анализа факторов, определяющих показатели добычи нефтти и газа. Предложено направление технологической диверсификации разработки нефотегазовых месторождений путем комбинирования технологий выщелачивания металлов в стенках природных и техногенных пустот после выемки углеводородов. Показано, что диверсификация технологий позволяет повысить рентабельность основного производства.

\section{КЛЮЧЕВЫЕ СЛОВА:} рентабельность, диверсификация технологий, выщелачивание металлов, нефть и газ, добавленная стоимость, экономика.

Статья поступила в редакцию 06.02 .2019

\section{Введение}

Нефть сегодня - не только энергоноситель, но и источник получения товарных продуктов. Освоение разведанных месторождений нефти является целью стран и регионов, поставленных перед необходимостью выживания в условиях жесткой конкуренции на мировом рынке.

При добыче нефти, как и при добыче многих других минеральных ресурсов, в мире отмечается ухудшение структуры разведанных запасов нефти и активизируется опережающая разработка наиболее богатых участков месторождений.

Большая часть подготавливаемых запасов в средних и мелких месторождениях относится к трудноизвлекаемым, коэффициент извлечения которых не превышает 10-25\%. Использование зарубежных технологий повышает уровень нефтедобычи, но без развития собственной науки в этом направлении Россия не имеет перспектив. В пореформенное время утрачены многие направления исследований процессов добычи и переработки нефти и газа. Тем актуальнее представляются технические решения, позволяющие повысить уровень рентабельности нефтедобычи в сложившихся трудных экономических условиях [1].

Добыча и переработка минерального сырья всегда была занятием населяющих нынешнюю территорию Северной Осетии народов. В новейшей истории Садонский свинцово-цинковый комбинат удовлетворял потребности России и СССР в свинце полностью и в цинке на две трети [2].

Причиной кризиса рудников Северной Осетии послужило несоответствие применяемых технологий разработки требованиям нового времени, в том числе, освоение инновационных технологий управления рудовмещающим массивом закладкой пустот твердеющими смесями и выщелачивания металлов из некондиционного сырья.

В пореформенное время горнодобывающие предприятия ищут пути сохранения экономики, в том числе, в диверсификации технологий добычи и переработке минерального сырья.

Не имея возможности возродить былые темпы добычи полиметаллов, Cеверная Осетия осваивает новое для нее направление добычи углеводородов из имеющихся на ее территории месторождений (рис.1).

Вариантом реализации этого направления является комбинирование традиционных технологий добычи нефти и газа и извлечения металлов путем выщелачивания из образованного выемкой углеводородов выработанного пространства [3-4].

Поиски путей оздоровления особенно актуальны для депрессивных регионов, к которым относится Республика Северная Осетия, для которой добыча и переработка минеральных ресурсов всегда была одним из основных источников дохода.

${ }^{1}$ Северо-Кавказский горно-металлургический институт (государственный технологический университет), 362021, Владикавказ, Россия

${ }^{2}$ Южно-Российский государственный политехнический университет, 346428, Ростовская область,. Новочеркасск, Россия

${ }^{3}$ Геофизический институт Владикавказского научного центра РАН, 362002, РСО-Алания. Владикавказ, Россия, e-mail: v.i.golik@mail.ru 


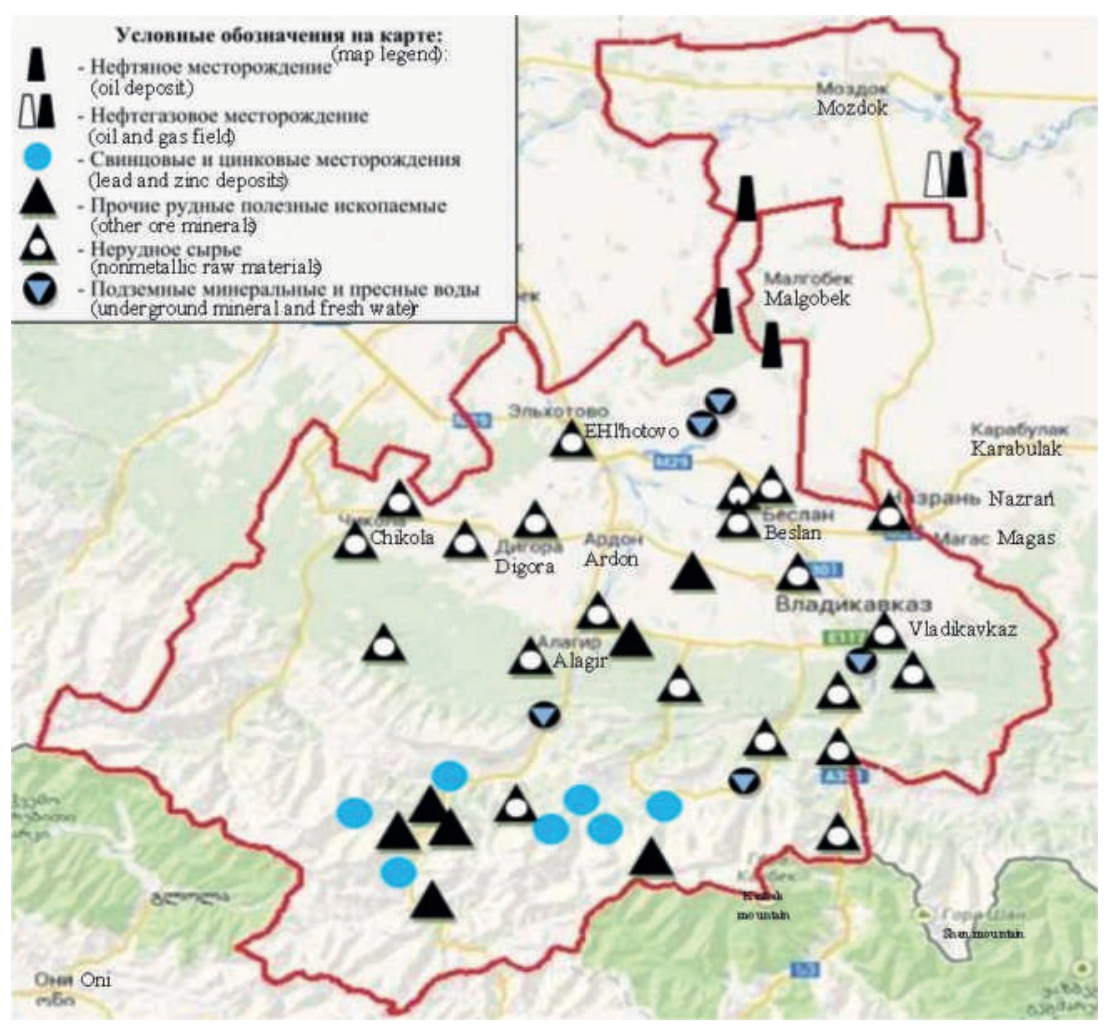

Pис. 1. Нефть и газ на карте месторождений полезных ископаемых Северной Осетии

Fig. 1. Oil and gas on the map of mineral deposits in North Ossetia

Металлы в нефти. Размещение полезных ископаемых Осетии связано с ее геологическим строением. Минеральные богатства образовались в связи с проникновением в земную кору расплавленной магмы по трещинам и разломам. При смешении паров с металлоносными газами возникали растворы, из которых образовывались месторождения полезных ископаемых. Нефть залегает в той части территории, которая образовалась осадочными породами. В нефти растворены металлы различных групп. В больших количествах по сравнению с другими элементами нефть содержит ванадий и никель. Так, содержание ванадия достигает $2 \cdot 10^{-2} \%$, никеля $-1 \cdot 10^{-2} \%$, что сопоставимо с концентрацией их в коренных рудах.

В металлоносной нефти месторождений мира представлены цветные, благородные редкие и редкоземельные металлы [5-9].

Наличие металлов в нефти является маркером содержания металлических компонентов во вмещающих углеводо-

В регионе ведутся поиски технологических решений, позволяющих использовать инфраструктуру и возможности исторически освоенных ресурсов, которыми являются металлы [5-6].

Исчерпание запасов путем опережающей выемки богатых руд по конъюнктурным соображениям лишает Садонский комбинат перспективы обновления производства на основе традиционных технологий, не отвергая возможности развития добывающей отрасли путем комбинирования традиционных и нетрадиционных технологий добычи ресурсов. В основе предлагаемых решений лежат работы Северо-Осетинского профессора Остроушко И.А., который доказал наличие металлов во вмещающих минеральные ресурсы породах, как минеральной базы для освоения инновационных технологий.

Целью исследования является прогнозирование возможности восстановления экономического потенциала региона путем диверсификации технологий разработки месторождений углеводородов.

Инструментом достижения цели является извлечение металлов из вмещающих нефть и газ пород.

\section{Материал и методы исследования}

Республика Северная Осетия-Алания обладает четырьмя разведанными месторождениями нефти, том числе: Северо-Заманкульское, Харбижинское, Северо-Ахловское, Красногорское с извлекаемыми запасами 4358 тыс. тонн.

Разведочными работами выявлено еще 7 перспективных нефтяных и газовых структур. роды породах. Часть металлов в нефти находится в виде солей, а основная масса - в форме сложных полидентатных комплексов.

Всего в нефти обнаружено более пятидесяти видов металлов. Среди металлов, содержание которых в нефти превышает 10 \%, доминируют V, Ni, Fe, Zn, Hg, $\mathrm{B}, \mathrm{Na}, \mathrm{K}, \mathrm{Ca}, \mathrm{Mg}$. Рений, молибден, ванадий и никель находятся в связи с органическим веществом, а медь, серебро, кадмий, селен и висмут - с сульфидами. Поэтому поиски технологий получения металлов из нефти представляют собой актуальную научно-производственную проблему.

Горы Северной Осетии богаты рудами цинка, свинца, серебра, молибдена, меди, олова, золота и мышьяка в бассейнах рек. Можно говорить, что массивы Осетии содержат металлов на единицу породной площади больше, чем массивы других регионов, что подтверждает вероятность металлизации вмещающих нефть и газ пород и возможность извлечения из пород металлов выщелачиванием.

Наличие металлов во вмещающих породах подтверждено геологическим методом бороздового опробования выработок Садонского рудника. Критическим пределом опробования принято суммарное содержание свинца и цинка 0,5. Статистической обработкой определено количество металлов в металлосодержащих породах стенок выработок (рис. 2). 


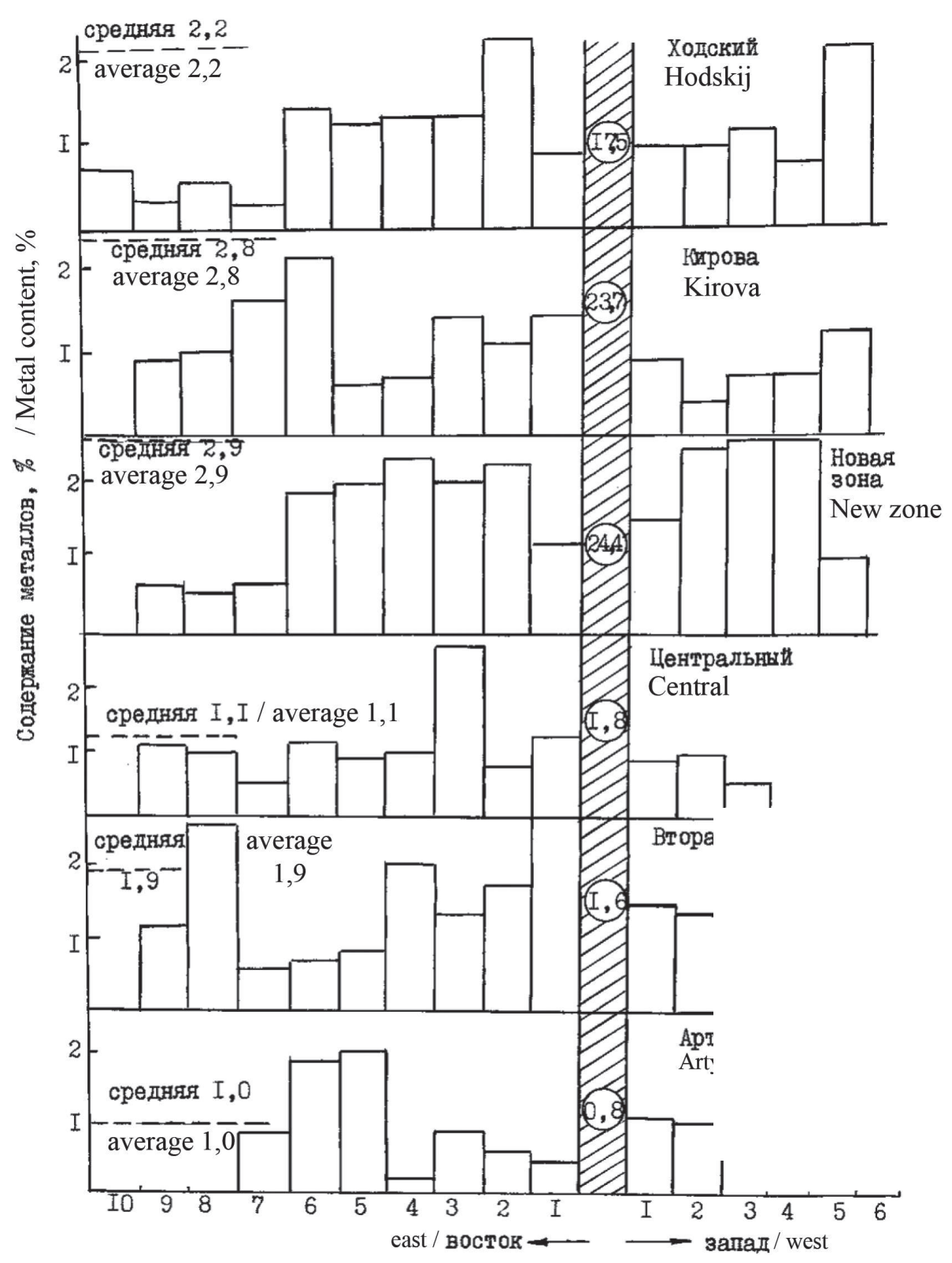

Pис. 2. Вариационные ряды гармоник содержания металлов Fig. 2. Variational rows of metal content harmonics
Этот феномен может быть использован для выщелачивания нефте- и газовмещающих природных и техногенных геологических и техногенных структур после извлечения из них углеводородов.

Комбинированное извлечение компонентов. Добыча углеводородов из горючих сланцев с получением одновременно и углеводородов и металлов заключается в объединении возможностей пиролиза и реагентного растворения металлов. В скважины нагнетают пар под давлением до 0,3 МПа, а в заключительной стадии - подают воду. Размягченную нефть выдают на поверхность

Вариант с внутрипластовым влажным горением извлеченнной нефти характеризуется тем, что повышение температуры до 400-700 ${ }^{\circ} \mathrm{C}$ создает условия для крекинга и выпаривания легких фракций нефти, вытесняемых образующейся смесью.

При обработке руд с температурой от $450^{\circ} \mathrm{C}$ органический материал разлагается на нефтепродукты, газ и кокс. Содержащиеся в сырье
Выщелачивание металлов из стенок. Метод извлечения металлов из кислых растворов природного и техногенного происхождения находит применение в горной промышленности [10-12].

На руднике Питч (США) рудные стенки выработок выщелачивали водой. На руднике Милликен (Канада) в выработки подавали шахтные воды и получали в растворе пригодное для переработки содержание урана.

Какадур-Ханикомское месторождение (РСО-Алания) в зоне разлома, сложенной слабыми песчаноглинистыми осадочными породами, подвергается природному выщелачиванию. В природных растворах при рН 5-6 концентрация цинка достигает 80$600 \Gamma / \mathrm{M}^{3}$.

Практикой извлечения металлов в раствор природными водами установлена адекватность процессов перевода металлов из вмещающих выработки пород в транспортабельное жидкое состояние [13-15]. металлы переходят в газ и конденсируются при температуре менее $200^{\circ} \mathrm{C}$. В нефтесодержащем массиве образуются пустоты, стенки которых испытывают напряжения от тектонических, гравитационных и термических сил. В зонах действия пустот развиваются увеличивающие проницаемость сырья трещины.

Поскольку в твердых углеводородах содержатся цветные, благородные и редкие металлы при разработке месторождений металлоносных углеводородов открывается перспектива получения в рамках одного процесса и нефти и металлов.

После извлечения углеводородов остаются доступные для последующего выщелачивания металлов минеральные среды. Опытом подземного выщелачивания урана нижний доступный для технологии предел его содержания характеризуется значением 0,01\%. Примерно столько же урана содержится в хвостах подземной газификации горючих сланцев.

Перевод металлов в мобильную фазу осуществля- 
ется по аналогии с применяемой уже более половины века технологией подземного и скважинного выщелачивания.

Одно из последствий разработки месторождений полезных ископаемых, в том числе и металлосодержащих горючих сланцев, является деформирование вмещающих пород вплоть до земной поверхности с негативными последствиями.

Разрушение вмещающего полезное ископаемое массива и земной поверхности негативно влияет на экономику и экологию региона, поэтому технологии с минимизацией опасности окружающей среде обладают приоритетом при равенстве прочих других показателей.

Выбор технологии комбинированной добычи углеводородного сырья заключается в обеспечении экологически корректного состояния рудовмещающего массива и минимизации затрат на добычу и переработку, а прибыль может быть определена моделью баланса затрат и экономии при получении энергетической и металлической продукции.

При интенсивной разработке крупных месторождений углеводородных руд затраты на охрану окружающей среды снижают рентабельность производства. Среди мер минимизации рисков для окружающей среды увеличивается актуальность технологии с уменьшением объемов извлекаемых из недр на земную поверхность минеральных масс.

Варианты термошахтной разработки месторождений углеводородов различаются расположением добывающих и нагнетательных скважин, характеризуются адекватными параметрами и процессами управления.

\section{Полученные результаты и их обсуждение}

Северная Осетия располагает запасами нефти и газа в месторождениях, которые можно отнести к группе малых и средних по величине и трудно-извлекаемых, что снижает рентабельность их эксплуатации. Поэтому использование только традиционной технологии добычи не обеспечивает конкурентоспособности эксплуатации месторождений и нуждается в технологической диверсификации (Остроушко И.А. Изыскание и внедрение способов извлечения металлов, оставленных в отработанных пространствах рудников: Отчет о НИР. Фонды СКГМИ. Орджоникидзе, 1975. 137 с.).

Диверсификация заключается в производстве нового товарного продукта - металлов, извлекаемых из стенок образуемых выемкой углеводородов пустот путем выщелачивания кислыми или основными растворами $[16 ; 17]$. Получаемый продукт с добавленной стоимостью повышает рентабельность и конкурентоспособность основного производства-добычи углеводородов.

Практика разработки нефтегазовых месторождений позволяет утверждать, что добываемая нефть содержит металлы, наличие которых объясняется генетикой месторождений. Металлы в нефти появились вследствие обмена с вмещающими породами в процессе формирования месторождений. Исследованиями параметров оруденения в стенках горных выработок установлена адекватность наличия металлов в границах бороздового опробования. Поэтому минеральная база диверсифицированного производства возрастает практически неограниченно и зависит только от возможностей переработки продукционного раствора металлов.

Адекватность выщелачивания металлов из вмещающих залежи полезного ископаемого, в данном случае нефти и газа, пород установлена экспериментально в условиях Садонских и других месторождений. Из шахтных стоков - полных аналогов природного выщелачивания - металлы извлекаются до необходимого значения, вплоть до фонового содержания. Технология извлечения металлов из раствора достаточно известна и совершенствуется путем повышения активности перерабатываемых сред в активаторах.

Инновационная технология выщелачивания металлов из стенок нефтевмещающих пород обладает преимуществами: хвосты выщелачивания увеличиваются в объеме и участвуют в сохранении геомеханической стабильности массива; бросовое металлосодержащее сырье в недрах перерабатывается с получением нового товарного продукта и улучшение экономики предприятия.

Преимуществами метода являются его экономичность и возможность отработки недоступных для традиционной технологии запасов.

История рекомендуемой технологии начинается с 50-х годов прошлого века. На Северном Кавказе забалансовые руды Быкогорского месторождения выщелачивали без отделения от массива с извлечением в раствор 59\% металлов.

Скважинное выщелачивание в настоящее время используют при извлечении металлов из недоступ-

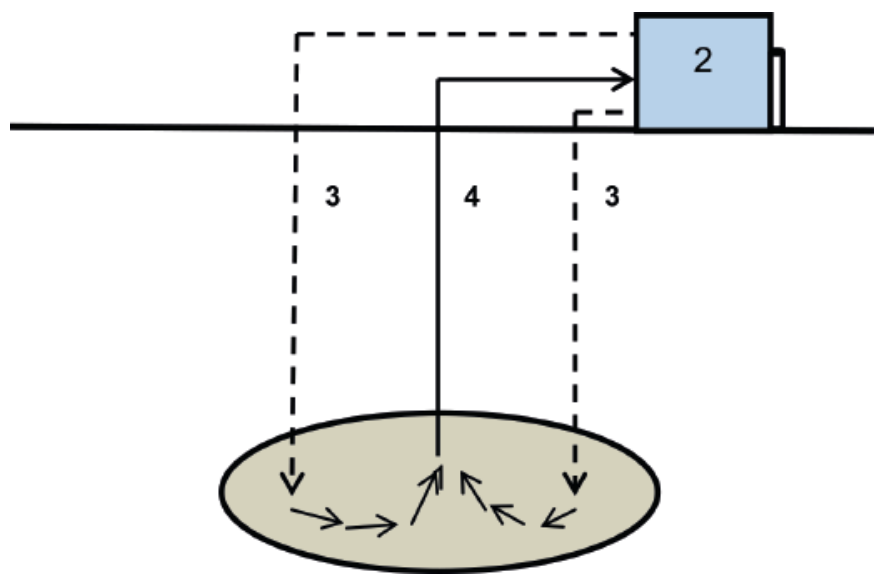

Pис. 3. Скважинное выщелачивание водо-насыщенных руд: 1 - рудное тело; 2 - иех переработки растворов; 3 подающие раствор скважины; 4 - выдающчая раствор скважина

Fig. 3. Borehole leaching of water-saturated ores: 1 -ore body; 2 - solution processing shop; 3 - solution feed wells; 4-solutionproducing well 


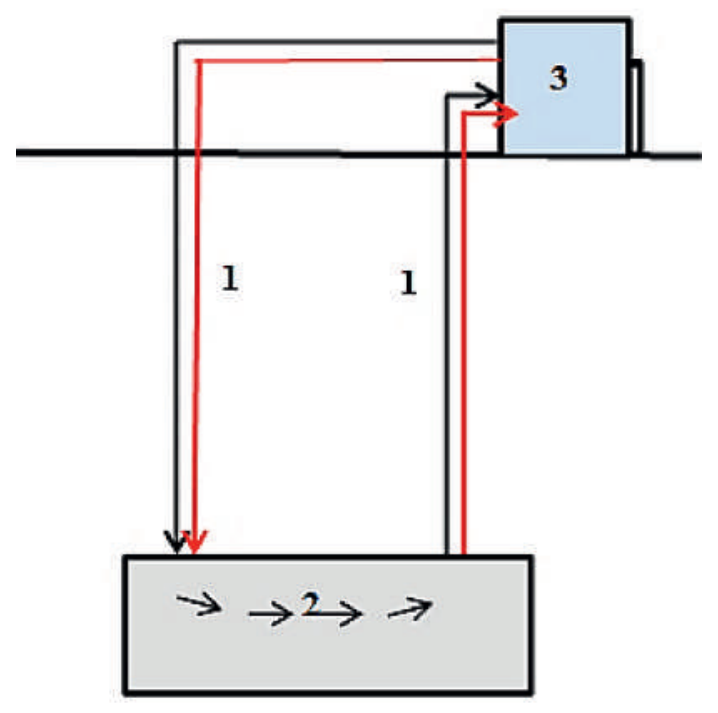

Pис. 4. Комбинированная технология с извлечением нефти и реагентным выщелачиванием металлов: 1 - скважины;

2 -залежь; 3 - участок переработки растворов

Fig. 4. Combined technology with oil recovery and reagent leaching of metals: 1-wells; 2 -deposit; 3 - solution processing section

ных залежей, например, из плывунов месторождения Семизбай в Казахстане (рис.3).

Суть предлагаемой технологии заключается в комплексировании процессов добычи нефти и выщелачивания металла с поверхности образованного добычей нефти выработанного пространства.

Вариант диверсификации предполагает извлече-

\section{ЛИТЕРАТУРА:}

1. Голик В.И., Комащенко В.И., Мартынов В.Г., Милетенко Н.В. Перспективы выщелачивания металлов при добыче нефти // Защита окружающей среды в нефтегазовом комплексе. 2018. N2. C.59-63.

2. Zarema M. Khasheva, V.I. Golik. The Ways of Recovery in Economy of the Depressed Mining Enterprises of the Russian Caucasus // International Business Management. 2015. N9 (6): pp. 1209-1216.

3. Дребенштедт К., Голик В. И., Дмитрак Ю. В. Перспективы диверсификации технологии добычи металлов в РСО-Алания // Устойчивое развитие горных территорий. N1. 2018. C.125-134.

4. Дмитрак Ю.В., Камнев Е.Н. АО "ведущий проектноизыскательский и научно-исследовательский институт промышленной технологии" - путь длиной в 65 лет // Горный журнал. 2016. N 3. С. 6-12.

5. Хулелидзе К.К., Кондратьев Ю.И., Бетрозов 3.С., Заалишвили В.Б. Оценка коренных и техногенных месторождений РСО-Алания как возможных объектов применения технологии подземного и кучного выщелачивания // Устойчивое развитие горных территорий. Владикавказ. 2016. N1. C.46-49.

6. Кондратьев Ю.И., Дзеранова К.Б., Малиева 3.В., Москвичева И.Ю. Выщелачивание полиметаллических руд серно-кислотно-хлоридными растворами на основе дегазированной воды с добавкой поверхностно-активного ве- ние нефти реагентным выщелачиванием металлов в две стадии.

На рис. 4 черным цветом обозначен этап извлечения нефти, а красным - этап выщелачивания металлов.

По мере извлечения нефти образуются пустоты, обрушение стенок которых увеличивает проницаемость реагентов в микротрещины пород стенок выработки при выщелачивании.

Экономический концепт диверсификации разработки нефтегазовых месторождений заключается в комбинировании процессов получения основной и дополнительной товарной продукции [18-20].

\section{Заключение}

Разработка углеводородов в условиях Северной Осетии характеризуется повышенными затратами, что снижает ее показатели и конкурентоспособность на рынке. Среди мер повышения рентабельности производства заслуживает внимания направление диверсификации производства с выпуском новой продукции - металлов.

При извлечении из недр углеводородов обнажаются транспортные магистрали для движения растворов выщелачивания металлов из металлосодержащих пород.

Комбинированная технология добычи углеводородов с получением одновременно углеводородов и металлов обеспечивает комплексное решение задач горного производства и является перспективным фактором полноты использования недр.

щества // Устойчивое развитие горных территорий. 2013. N 1. C.57-54.

7. Prior T., Giurco D., Mudd G., Mason L., Behrisch J. Resource depletion, peak minerals and the implications for sustainable resource management // Glob. Environ. Chang. 2012. N22. Pp. 577-587.

8. Sinclair L., Thompson J. In situ leaching of copper: Challenges and future pro spects // Hydrometallurgy. 2015. V. 157. Pp. 306-324.

9. Adibi N., Ataee-pour M., Rahmanpour M. Integration of sustainable development concepts in open pit mine design // J. Clean. Prod. 2015. Vol. 108. Pp. 1037-1049.

10. Ляшенко В.И. Природоохранные технологии освоения сложноструктурных месторождений полезных ископаемых // Маркшейдерский вестник. 2015. N1. C. 10-15.

11. Молев М Д., Страданченко С. Г. Использование синергетических возможностей геофизических методов при прогнозировании результатов техногенных воздействий // Горный информационно-аналитический бюллетень. 2016. N2. C. 306-313.

12. Каплунов Д. Р., Рыльникова М. В., Радченко Д. Н. Научно-методические основы проектирования экологически сбалансированного цикла комплексного освоения и сохранения недр Земли // Горный информационно-аналитический бюллетень. 2015. N4 (специальный выпуск N 15). C. 5-11. 
13. Емельяненко Е.А. Совершенствование технологии переработки теннантитсодержащих руд медноколчеданных месторождений Урала / М.В. Рыльникова, Е.А. Емельяненко Е.А., Е.А. Горбатова, Ю.Р. Ягудина // Горный журнал. 2016. N12. C.65-72.

14. Rachwa M., Magiera T., Wawer M. Coke industry and steel metallurgy as the source of soil contamination by technogenic magnetic particles, heavy metals and polycyclic aromatic hydrocarbons // Chemosphere. 2015. N. 138. Pp. 863-873.

15. Randolf E., Miller Sh., Miller G. Minimizing acid consumption in mixed oxide/supergene and sulfide heap leach // Proceedings of the 3rd International Conference on Heap Leach Solution. Lima. 2015. Pp. 36-44.

16. Каплунов Д.Р., Рыльникова М.В., Радченко Д.Н. Реализация концепции устойчивого развития горных территорий - базис расширения минерально-сырьевого комплекса России // Устойчивое развитие горных территорий. 2015. N3. C. 46-50.
17. Bosikov I. I.,. Klyuev R. V, Revazov V. Ch., Performance evaluation of functioning of natural-industrial system of mining-processing complex with help of analytical and mathematical models // IOP Conference Series: Materials Science and Engineering, 2018. 2018 IOP Conf. Ser.: Mater. Sci. Eng. 327022013.

18. Аликулов Ш.Ш., Нажимов Ф.Ф. Анализ базовой модели подземного выщелачивания урана к природным условиям месторождения // Горный информационно-аналитический бюллетень. 2015. N3.

19. Грязев М.В., Качурин Н.М., Захаров Е.И. Тульский государственный университет: 85 лет на службе отечеству // Горный журнал. 2016. N 2. С. 25-29.

20. Chen T., Lei C., Yan B., Xiao X. Metal recovery from the copper sulfide tailing with leaching and fractional precipitation technology // Hydrometallurgy. 2014. Vol. 147148. Pp. 178-182.

\section{СВЕДЕНИЯ ОБ АВТОРАХ / Information about authors:}

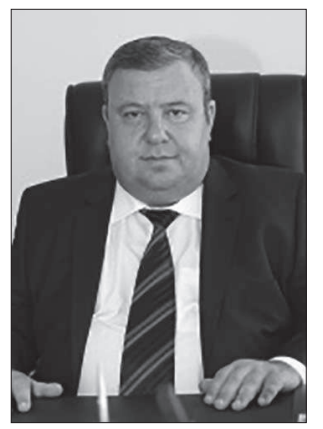

ЦИДАЕВ Батраз Саламович кандидат технических наук, проректор, заведующий кафедрой «Нефтегазовое дело», Северо-Кавказский горно-металлургический институт (государственный технологический университет).

362021, Владикавказ, Россия.

Тел.: 8(8672)40-71-04

Batraz S. TSIDAEV - Candidate of Technical Sciences, Vice Rector, Head of the Department "Oil and Gas", North-Caucasian Institute of Mining and Metallurgy (State Technological University). 362021, Vladikavkaz, Russia. Ph.: 8(8672)40-71-04

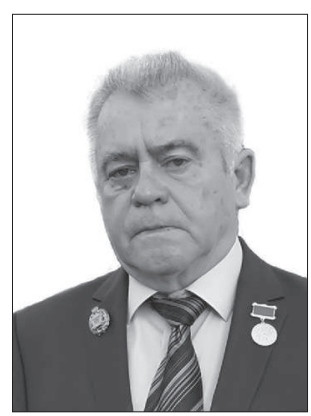

ГОЛИК Владимир Иванович доктор технических наук, професcop. Геофизический институт Владикавказского научного центра РАН, 362002, Владикавказ, Россия.

Тел.: 8 (952) 839- 45-99

E-mail: v.i.golik@mail.ru

Vladimir I. GOLIK - Doctor of Technical Sciences, Full Professor, Geophysical Institute of Vladikavkaz Scientific Center of the Russian Academy of Sciences, 362002, Vladikavkaz, Russia. Ph.: 8 (952) 839- 45-99,

E-mail:v.i.golik@mail.ru

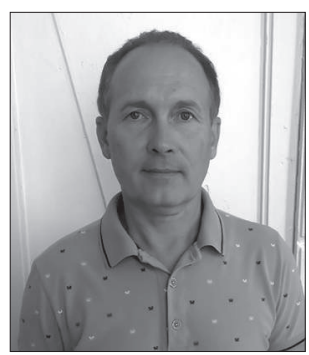

ЛОГАЧЕВ Александр Владимирович - кандидат технических наук, доцент кафедры «Горное дело», Южно-Российский государственный политехнический университет, 346428, Ростовская область, Новочеркасск, Россия.

Тел.: +7 (928)102-71-71, E-mail: log.a@bk.ru

Alexander V. LOGACHEV - Candidate of Technical Sciences, Associate Professor of Mining Department, South-Russian State Polytechnic University, 346428, Rostov region, Novocherkassk, Russia.

Ph.:+7 (928)102-71-71,E-mail: log.a@bk.ru

\section{PROFITABILITY INCREASE FOR OIL PRODUCTION BY DIVERSIFICATION OF TECHNOLOGIES}

${ }^{1}$ B. S. Tsidaev,

${ }^{2}$ A. V. Logachev,

${ }^{3}$ V. I. Golik*

${ }^{1}$ North-Caucasian Institute of Mining and Metallurgy (State Technological University), 362021, Vladikavkaz, Russia

${ }^{2}$ South-Russian State Polytechnic University, 346428, Rostov region, Novocherkassk, Russia

${ }^{3}$ Geophysical Institute of Vladikavkaz Scientific Center of the Russian Academy of Sciences, 362002, Vladikavkaz, Russia,E-mail:v.i.golik@mail.ru

DOI: $10.21177 / 1998-4502-2019-11-1-98-104$

During the reformation period, technical solutions are relevant, allowing to increase the level of production profitability in the current difficult economic conditions. In due time, North Ossetia met the needs of Russia and the USSR in lead com- 
pletely and in zinc by $2 / 3$. Not having the opportunity to revive the former rates of the mineral production, North Ossetia is developing a new direction for its hydrocarbon production. The proposed solutions are based on the works of professor Ostroushko IA, who proved the presence of metals in the host mineral resources as a mineral base for the development of innovative technologies. The aim of the study is to substantiate the possibility of restoring the economic potential of the region through the diversification of technologies for the development of hydrocarbon deposits and a tool to achieve the goal is the extraction of metals from the rocks containing oil and gas. Metals, more than fifty kinds of metals, are dissolved in oil. The presence of metals in the host rocks was confirmed by the method of furrow testing of the workings. The possibility of leaching metals from intact metal-bearing rocks is confirmed by the practice, for example, of the Kakadur-Khanikomskoye field (RSO-A). This phenomenon can be used for leaching oil and gas containing natural and man-made geological and man-made structures after the extraction of hydrocarbons from them. Using only the traditional oil production technology does not ensure the competitiveness of field exploitation and needs technological diversification, which consists of the production of a new commercial product - metals extracted from the walls of the voids formed by the extraction of hydrocarbons by leaching. The resulting value-added product increases the profitability and competitiveness of the main production. The mineral base of diversified production increases almost unlimited. The advantages of the method are its cost-effectiveness and the possibility of developing reserves that are inaccessible for traditional technology. The diversification option involves the extraction of oil and reagent leaching of metals in two stages. As oil is extracted, voids are formed, the collapse of the walls of which increases the permeability of the reagents into the micro cracks of the excavation walls rocks during leaching. The economic concept of diversifying the development of oil and gas fields is to combine the processes of obtaining the main and additional commercial products.

Keywords: profitability, diversification of technologies, leaching of metals, oil and gas, value added, economic.

\section{References}

1. Golik V.I., Komaschenko V.I., Martynov V.G., Miletenko N.V. Prospects for leaching of metals in oil production. Environmental Protection in the Oil and Gas Complex,2018, no.2, pp. 59-63.

2. Zarema M. K., Golik V.I. The Depressed Mining Enterprises of the Russian Caucasus. International Business Management, 2015, no. 9 (6), pp. 1209-1216.

3. Drebenshtedt K., Golik V.I., Dmitrak Yu.V. Prospects for the diversification of technology for the extraction of metals in RNO-Alania. Sustainable Development of Mountain Territories, 2018, no.1, pp.125-134.

4. Dmitrak Yu.V., Kamnev E.N. AO "Leading design and survey and research institute of industrial technology" - a path length of 65 years. Mining Journal, 2016, no. 3, pp.6-12.

5. Khulelidze K.K., Kondratiev Y.I., Betrozov Z.S., Zaalishvili V.B. Estimation of primary and technogenic deposits of the Republic of North Ossetia-Alania as possible objects for the application of underground and heap leaching technology. Sustainable Development of Mountain Territories. Vladikavkaz, 2016, no. 1, pp. 46-49.

6. Kondratyev Yu.I., Dzeranova K.B., Maliyeva Z.V.,
Moskvicheva I.Yu. Leaching of polymetallic ores with sulfuric acid-chloride solutions based on degassed water with the addition of a surfactant. Sustainable Development of Mountain Territories, 2013, no. 1, pp.57-54.

7. Prior T., Giurco D., Mudd G., Mason L., Behrisch J. Resource depletion, Peak Minerals and Sustainability for Sustainable Resource Management. Glob. Environ. Chang. Sustainable Development of Mountain Territories, 2012, no. 22, pp.577-587.

8. Sinclair L., Thompson J. In situ leaching of copper: Challenges and future pro spects. Hydrometallurgy, 2015, Vol. 157 , pp. 306-324.

9. Adibi N., Ataee-pour M., Rahmanpour M. Integration of sustainable mine development concepts in open mine design. J. Clean. Prod., 2015, Vol. 108, pp. 1037-1049.

10. Lyashenko V.I. Environmental protection technologies for development of complex structural mineral deposits. Mining Bulletin, 2015, no.1, pp.10-15.

11. Molev M. D., Stradanchenko S. G. Use of synergistic capabilities of geophysical methods in predicting the results of technogenic impacts. Mining Informational and Analytical Bulletin, 2016, no. 2, pp. 306-313.

12. Kaplunov D. R., Rylnikova M. V., Radchenko D. N. Scientific and Methodological Basis for Designing an Environmentally Balanced Cycle for Integrated Development and Conservation of the Earth's Subsoil. Mining Informational and Analytical Bulletin, 2015, no. 4 (special edition number 15), pp. 5-11.

13. Rylnikova M.V., Yemelyanenko E.A., Gorbatova E.A. and Yagudin Yu.R. Improving the technology of processing tennantite-containing ores of copper-sulphide deposits of the Urals. Mining Journal, 2016, no. 12, pp. 65-72.

14. Rachwa M., Magiera T., Wawer M. Coke and polycyclic aromatic hydrocarbons. Chemosphere, 2015, no. 138, pp. 863-873.

15. Randolf E., Miller Sh., Miller G. Minimizing acid consumption and oxide / supergene and sulfide heap leach. Proceedings of the 3rd International Conference on Heap Leach Solution. Lima, 2015, pp. 36-44.

16. Kaplunov D.R., Rylnikova M.V., Radchenko D.N. The implementation of the concept of sustainable development of mountain areas is the basis for the expansion of the mineral resource complex of Russia. Sustainable Development of Mountain Territories, 2015, no. 3, pp. 46-50.

17. Bosikov I. I.,. Klyuev R. V, Revazov V. Ch., Performance evaluation of functioning of natural-industrial system of mining-processing complex with help of analytical and mathematical models. IOP Conference Series: Materials Science and Engineering, 2018. 2018 IOP Conf. Ser.: Mater. Sci. Eng. 327022013.

18. Alikulov Sh.Sh., Nazimov F.F. Analysis of the basic model of underground leaching of uranium to the natural conditions of the field. Mining Informational and Analytical Bulletin, 2015, no. 3 .

19. Gryazev MV, Kachurin N.M., Zakharov E.I. Tula State University: 85 years in the service of the fatherland. Mining Journal, 2016, no. 2, pp. 25-29.

20. Chen T., Lei C., Yan B., Xiao X. Metal recovery from the copper sulfide technology. Hydrometallurgy, 2014, vol. 147-148, pp. 178-182.

Article received 06.02.2019. 


\section{НАУЧНОЕ МНЕНИЕ}

SCIENTIFIC OPINION

Наука - великое украшение и весьма полезное орудие...

М. МОНТЕНЬ

\section{TECHNOLOGICAL SOLUTIONS FOR INTENSIVE WORKING OF MEDIUM THICK INCLINED COAL SEAMS IN DIFFICULT CONDITIONS IN THE MINES OF THE QUANG NINH COAL BASIN}

\section{Introduction}

The state ten-year plan for the development of the national economy of the Socialist Republic of Vietnam for 2015-2025 it is planned to increase coal production in 2025 to 71.1 million tons [1]. It has been planned to extract up to $85 \%$ of coal by the underground method. At the same time, the level of coal production from 2016 to 2025 by the underground method should increase from $46 \%$ to $90 \%$ and amount to 63.1 million tons. The level of mining by the open pit method will decrease from $54 \%$ to $10 \%$ and will fluctuate within 8 million tons in 2025 [2-6].

The contribution of coal production from complex-mechanized faces in the total underground mining in 2017 comprise to 3\%, whereas coal mining using drilling and blasting operations and loading coal manually on the conveyor was $95 \%$. However, for the coal industry of Vietnam, there remains a serious problem of coal mining from medium thick inclined coal seams, which are concentrated upto $24,03 \%$ of the total balance reserves of coal. This is due to the very complicated mining and geological conditions of occurrence of coal seams that are subject to intense disjunctive disturbance, which makes it difficult to use highly productive preparation systems and modern means of combined mechanization.

The solution to these problems by adapting the well-known and newly developed temporary technological schemes of mines reproduces the limitations for realizing the potential of efficient working equipment [7]. As a result, the level of profitability of the mines of the Quang Ninh coal basin does not satisfy modern requirements [8;9]. Therefore, serious research and investments are needed in the development of new coal mining technologies when working with medium thick inclined coal seams occurring in unfavourable mining and geological conditions, as well as in developing theoretical foundations in the field of spatial orientation of complicated systems and creating highly efficient means of combined mechanization.

\section{Substantiation and technological solutions}

For the working off medium thick inclined coal seams, a significant variety of the various mining methods is used, depending on the geological and mining conditions of the coal seams. Until now, there is no technological scheme that

${ }^{1}$ Quang Ninh University of Industry, Vietnam

${ }^{2}$ Hanoi University of Mining and Geology, E-mail: phamducthangmct@gmail.com
1 Thang P.D.,

${ }^{1}$ Thang H.H., * ${ }^{2}$ Phuc L.Q.
УДК: 622.273.3:622.014

DOI: 10.21171/1998-4502-201911-1-105-109

Analyzed the promising direction of implementation of the state plan for the extraction of coal in Vietnam largely depends on the efficiency of further industrial development of the potential of the Quang Ninh coal basin. An analysis of the limitations of the application of technologies, depending on the complexity of the mining geological and mining technological conditions of the Quang Ninh coal basin, is given. Analyzed the possibility and feasibility of using the room and pillar method based on the analysis of foreign experience in mining coal seams. An innovative technological scheme of highly efficient mining of medium thick inclined coal seams with a diagonal disposition of the line of face with the use of self-moving supports along articulated joints was proposed. A block diagram of the choice of mining method is based on the angle of dip classification of coal seams.

\section{KEYWORDS:}

inclined coal seams, mining method, room and pillar method, technological scheme, diagonal face, Quang Ninh, technological solutions 


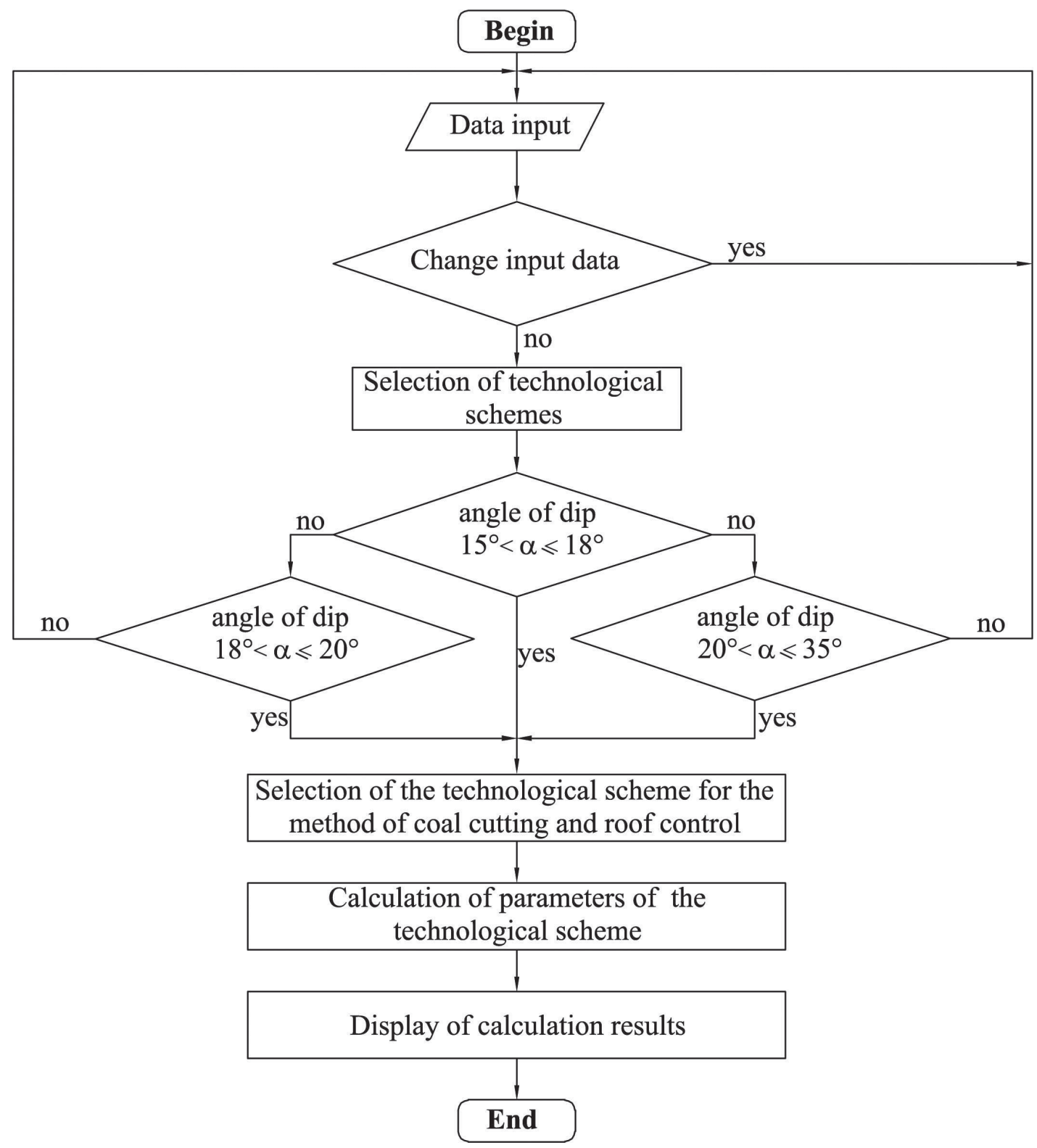

Fig. 1. The block diagram of the algorithm for selecting the mining method of medium thick inclined coal seams

could be universal for all mines of the Quang Ninh coal basin $[9 ; 10]$.

In the Quang Ninh coal basin, the use of traditional technological schemes of extraction medium thick inclined coal seams and means of mechanization with the drilling and blasting method of mining does not correspond adequately to modern requirements improving the safety and productivity of coal mining in the faces. Therefore, there is a need to introduce a complex-mechanized mining of reserves of medium thick inclined coal seams of the Quang Ninh basin, based on innovative and high-quality technological solutions aimed at the development strategy of the coal industry of Vietnam.

For technological solutions, when working off the reserves of the Quang Ninh coal basin, it is necessary to implement an integrated approach to their classification based on their division into suitable for mining by tradi- tional methods and $67 \%$ of reserves suitable for mining by non-traditional technologies. Significant reserves of coal in the Quang Ninh basin are located in zones of geological disturbances, in areas of mine fields with limited reserves, which are advisable to work out in a room and pillar method [11-13].

Based on the analysis of mining and the geological conditions coal deposits of Vietnam and long experience of their mining, as well as the prospects for the development of underground coal mining in the advanced coal mining countries of the world, for certain mining and geological and mining conditions, the most promising technology for mining is medium thick inclined coal seams, there will be a room and pillar method and diagonal technology (diagonal faces) with the control of rock pressure in the mining face with self-moving supports with articulated joints.

Currently, in the Vietnamese coal industry there are 


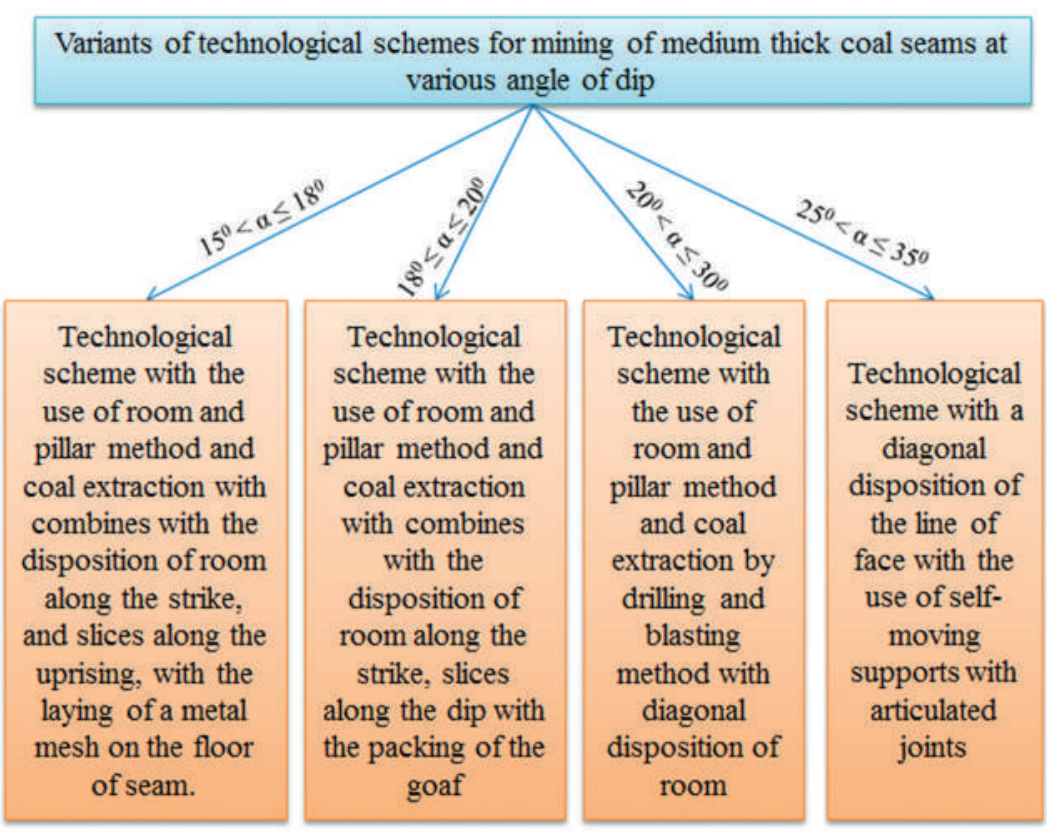

Fig. 2. Direction of technology for mining medium thick inclined coal seams of the Quang Ninh coal basin

no regulatory documents defining the parameters and safety requirements for the room and pillar method, there are no practices and criteria for calculating the parameters of this technology, in connection with the development of a standard project for working out the floor is an urgent task.

The introduction of these technologies allows to provide:

A significant reduction in the initial capital costs on the purchase of equipment and the preparation of the mine section;

Increase of the load on the face and the effective utilization by the means of combined mechanization at the diagonal arrangement of the line of face;

Mobility and high adaptability of room and pillar method to the complicated mining and geological conditions will make it possible to effectively work out mining fields of insignificant size along strike;

The use of one type of equipment at the preparatory and mining works, the minimum amount or the complete absence of work on the support and control of the roof, allow significantly reduce capital costs.

The technologies of mining coal seams with a room and pillar method have been successfully used in the USA, South Africa, Australia, but they are mainly used for gently sloping seams in favorable geological conditions.

Room and pillar method with the utilizatione of mechanization is a new type of mining technology, promising at angles of incidence from 15 to $25^{\circ}$ and insignificant dimensions of the level along strike.

The diagonal technology (diagonal faces) is a new solution for the effective and safe extracting of medium thick inclined coal seams $\left(25 \div 35^{\circ}\right)$ using self-moving supports with articulated joints and diagonal disposition of the line of face.

From an analysis of the prospects for the development of the coal industry in Vietnam, it follows that the reserve for improving the efficiency of underground mining of medium thick inclined coal seams lies in the complex use of various technologies adapted to specific mining geological and mining technological conditions, with application room and pillar method and coal mining with longwall with diagonal disposition of line of face.

In accordance with the accepted rules and regulations for the extraction of coal and shale in the mines of Vietnam, according to the classification, coal seams are divided by angle of dip: gently sloping seams with an angle of dip from 0 to $15^{\circ}$; inclined seams with an angle of dip from 15 to $35^{\circ}$; steeply inclined seams with an angle of dip from 35 to $55^{\circ}$; steep seams with an angle of dip from 56 to $90^{\circ}$; therefore within the limits of research of paper of one work the inclined seams with an angle of dip 15 to $35^{\circ}$ is accepted.

Based on the analysis of the technology of mining medium thick inclined coal seams in the mines of Vietnam, as well as the world experience of underground coal mining and taking into account these specific mining and geological conditions of occurrence of medium thick inclined coal seams of the Quang Ninh coal basin, the author developed directions of technology and a block diagram of the mining method selection depending on the angle of dip (Fig. 1), as well as recommendations and variants for technological schemes, which are shown in Fig. 2.

\section{Conclusions}

The alternative variants of mining method, adaptive to mining and geological conditions when extracting medium thick inclined coal seams of the Quang Ninh coal basin of Vietnam in difficult conditions are substantiated. In addition, it is possible to use the mining technology for working off medium thick inclined coal seams in other coal regions of Vietnam and foreign.

A block diagram of the algorithm for selecting the mining method of medium thick inclined coal seams has been developed, corresponding to the classification of coal seams by the angle of dip according to the standards of technological design. 
REFERENCES / ЛИТЕРАТУРА:

1. Pham Duc Thang, Vitcalov V.G., Pham Ngoc Huynh. Strategy for the development of the coal industry and the possibility of using mechanized technology in coal mining at the Quang Ninh coal basin of Vietnam. Mining Informational and Analytical Bulletin, 2017, No 10, pp. 65-70.

2. Pham Trung Nguyen. Prospects development of Vietnam coal industry. Mining Informational and Analytical Bulletin, 2011, No 2, pp. 359-363.

3. Nguyen Canh Nam. Development of Vietnam's coal industry. Mining and Industrial Journal, 2017, no1, pp.60-66.

4. Nguyen Tien Chinh. State of coal cost, forecast of coal cost in the country and imports to Vietnam. Mining and Industrial Journal, 2017, no 6, pp.78-84.

5. Nguyen Thi Hoai Nga, Nguyen Canh Nam. Overview of the global coal industry and the possible export of coal to Vietnam. Mining and Industrial Journal, 2017, no 4, pp.90-95.

6. Nguyen Hoang Huan, Phi Chi Thien. The study and evaluation the resources of the Quang Ninh coal basin for effective exploration planning and development. Mining and Industrial Journal, 2017, no2, pp.102-107.

7. Kazanin O.I., Le Van Hau. Statement and perspectives of the underground coal mining technology development at Quang Ninh coal basin of Vietnam. Mining Informational and Analytical Bulletin, 2014. no 5, pp. 15-20.
8. Zubov V.P., Pham Quang Nam, Vu Thai Tien Dung. Improving the development of gently sloping seams with thick of 2.5-5.0 $\mathrm{m}$ in the conditions of the mines of the Quang Ninh basin of Vietnam. Mining Informational and Analytical Bulletin, special issue 60-1, 2015, pp. 89-97.

9. Vitcalov V.G., Pham Duc Thang. Study of technological solutions for mining inclined coal seams in the mines of quang ninh coal basin. Mining Informational and Analytical Bulletin. no. 10, 2017, pp. 113-121.

10. Vitcalov V.G., Nguyen Anh Tuan, Pham Duc Thang. Justification of design solutions for the preparation and working off inclined thick coal seams of the Quang Ninh basin. Mining Informational and Analytical Bulletin. 2011, No 9, pp. 25-31.

11. Filatov Y.M., Sementsov V.V., Prokopenko S.A., Ermolaev A.M., Sobolev V.V. Efficiency and safety improvement of pillar recovery during room and pillar coal mining. Ugol', 2018, no. 12, pp. 16-20.

12. Wael Rashad Elrawy Abdellah. Parametric stability analysis of room and pillar method in deep coal mines. Journal of Engineering Sciences, 2015, vol. 43, no. 2, pp.253-262.

13. Singh Satyendra K., Agrawal Harshit, Singh Awanindra P., Rib stability: A way forward for safe coal extraction in India. International Journal of Mining Science and Technology, 2017, vol. 27, pp 1087-1091.

\section{СВЕДЕНИЯ ОБ АВТОРАХ / Information about authors:}

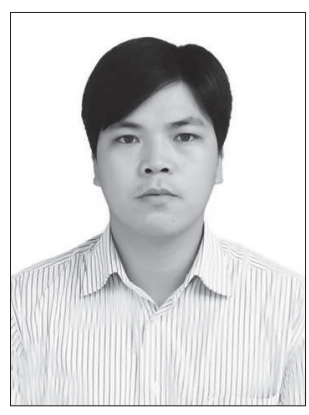

Pham Duc THANG - Lecturer of Quang Ninh University of Industry.

Yen Tho - Dong Trieu, Quang Ninh - Viet Nam

E-mail: phamducthangmct@gmail.com

Фам Дик ТХАНГ - преподаватель Куангниньского индустриального университета.

Иентхо-Донгчеу, Куангнинь, Вьетнам E-mail:phamducthangmct@gmail.com

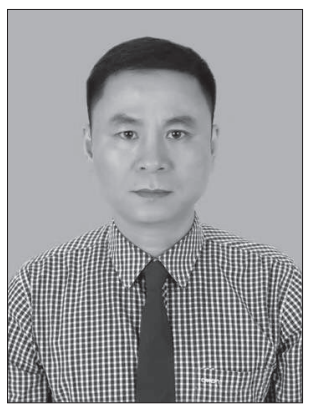

Hoang Hung THANG - Rector of Quang Ninh University of Industry

Yen Tho - Dong Trieu, Quang Ninh - Viet Nam

E-mail: hoanghungthang@qui.edu.vn

Хоанг Хунг ТХАНГ - ректор Куангниньского индустриального университета Иентхо - Донгчеу, Куангнинь, Вьетнам

E-mail: hoanghungthang@qui.edu.vn

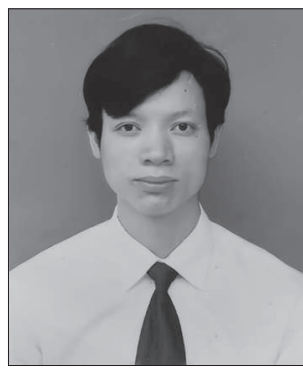

Le Quang PHUC - Lecturer of Hanoi University of Mining and Geology

Duc Thang - Bac Tu Liem, Hanoi, Vietnam

E-mail: lequangphuc@humg.edu.vn

Ле Куанг ФУК - преподаватель Ханойского горно-геологического университета, Ханой, Вьетнам.

E-mail:lequangphuc@humg.edu.vn 


\title{
ТЕХНОЛОГИЧЕСКИЕ РЕШЕНИЯ ПО ИНТЕНСИВНОЙ ОТРАБОТКЕ НАКЛОННЫХ УГОЛЬНЫХ ПЛАСТОВ СРЕДНЕЙ МОЩНОСТИ В СЛОЖНЫХ УСЛОВИЯХ НА ШАХТАХ МЕСТОРОЖДЕНИЯ КУАНГНИНЬ
}

\author{
'Фам Дик Тханг, \\ ${ }^{1}$ Хоанг Хунг Тханг, \\ ${ }^{2}$ Ле Куанг Фук
}

\section{${ }^{1}$ Куангниньский индустриальный университет, Bветнам, phamducthangmct@gmail.com}

${ }^{2}$ Ханойский горно-геологический университет, Ханой, Вьетнам.

\section{DOI: $10.21177 / 1998-4502-2019-11-1-105-109$}

Проанализировано перспективное направление выполнения государственного плана по добыче угля Вьетнама в значительной степени зависит от эффективности дальнейшего промышленного освоения потенциала бассейна Куангнинь. Приведен анализ ограничений, применения технологии в зависимости от сложности горно-геологических и горнотехнических условий Куангнинского угольного бассейна.

Проанализирована возможность и целесообразность применения камерно-столбовой системой разработки на основе анализа зарубежного опыта отработки угольных пластов. Предложена инновационная технологическая схема высокоэффективной отработки наклонных угольных пластов средней мощности с диагональным расположением линии очистного забоя с применением самопередвигающихся шарнирно-оградительных крепей. Основана блок-схема выбора систем разработки на классификации угольных пластов по углу падения.

Ключевые слова: наклонный угольный пласт, система разработки, камерно-столбовая система, технологическая схема, очистной забой, Куангнинь, технологические решения.

\section{Литература}

1. Фам Дик Тханг, Виткалов В.Г., Фам Нгок Хюнь. Стратегия развития угольной промышленности и возможность применения механизированной технологии добычи угля в Куангнинском угольном бассейне Вьетнама // Горный информационно-аналитический бюллетень. 2018. N8. C. 65-70.

2. Фам Чунг Нгуен. Перспективы развития угольной промышленности социалистической республики Вьетнам // Горный информационно-аналитический бюллетень. 2011. N2. C. 359-363.

3. Nguyen Canh Nam. Development of Vietnam's coal industry // Mining and Industrial Journal. 2017. N1. Pp. 60-66.

4. Nguyen Tien Chinh. State of coal cost, forecast of coal cost in the country and imports to Vietnam // Mining and Industrial Journal. 2017. N6. Pp. 78-84.

5. Nguyen Thi Hoai Nga, Nguyen Canh Nam. Overview of the global coal industry and the possible export of coal to Vietnam // Mining and Industrial Journal. 2017. N4. Pp. 90-95.

6. Nguyen Hoang Huan, Phi Chi Thien. The study and evaluation the resources of the Quang Ninh coal basin for effective exploration planning and development // Mining and Industrial Journal. 2017. N2. Pp. 102-107.

7. Казалин О. И., Ле Ван Хау. Состояние и перспективы развитие технологии подземной добычи угля в бассейне Куангнинь Вьетнама // Горный информационно-аналитический бюллетень. 2014. N5. С. 15-20.

8. Зубов В.П., Фам Куанг Нам, Ву Тхай Тьен Зунг. Совершенствование систем разработки пологих угольных пластов мощностью 2,5-5,0 м в условиях шахт Куангниньского бассейна Вьетнам // Горный информационно-аналитический бюллетень специальный выпуск 60-1. 2015. С. 89-97.

9. Виткалов В.Г, Фам Дик Тханг. Обоснование технологических решений по отработке наклонных угольных пластов на шахтах куангнинского угольного бассейна // Горный информационно-аналитический бюллетень. 2017. N10. C. 113-121.

10. Виткалов В.Г., Нгуен Ань Туан, Фам Чунг Нгуен. Обоснование проектных решений по подготовке и отработке наклонных мощных угольных пластов Куангниньского бассейна // Горный информационно-аналитический бюллетень. 2011. N9. С. 25-31.

11. Ю.М. Филатов, В.В. Семенцов, С.А. Прокопенко, А.М. Ермолаев, В.В. Соболев. Повышение эффективности и безопасности отработки целиков при камерно-столбовой системе разработки угольных пластов. Уголь. 2018. N12. C. 16-20.

12. Wael Rashad Elrawy Abdellah. Parametric stability analysis of room and pillar method in deep coal mines // Journal of Engineering Sciences. 2015. Vol.43, no 2. Pp. 253-262.

13. Singh Satyendra K., Agrawal Harshit, Singh Awanindra P., Rib stability: A way forward for safe coal extraction in India // International Journal of Mining Science and Technology. 2017. Vol.27. Pp 1087-1091.

Статья поступила в редакциию 30.01.2019. 


\section{ГЛУБОКОУВАЖАЕМЫЕ КОЛЛЕГИ!}

В соответствии с Заключением Президиума ВАК Минобрнауки РФ от 19.12.2014 2. №47/307 с 2015 года статьи для публикации в журнале «Устойчивое развитие горных территорий» принимаются по следующим отраслям и группам наук:

25.00.00 Науки о Земле (вся отрасль наук о Земле);

05.00.00 Технические науки (три группы из отрасли):

05.05.00 Транспортное, горное и строительное машиностроение,

05.13.00 Информатика, вычислительная техника и управление,

05.14.00 Энергетика.

B соответствии с градацией наук, принятой в международных системах цитирования Scopus и Web of Science, статьи для публикации в журнале «Устойчивое развитие горных территорий» принимаются по следующим отраслям и группам наук:

1. Engineering (технические науки);

2. Earth and Planetary Sciences (науки о Земле и планетарные науки);

3. Environmental Science (наука об окружающей среде).

В журнале «Устойчивое развитие горных территорий» печатаются:

- статьи с изложением новых научных результатов, объемом не более 10 машинописных страниц, включая иллюстрации и таблицы;

- краткие сообщения, содержащие информацию о важных результатах предварительных исследований, объемом 3-5 страниц (эти материалы впоследствии могут использоваться в тексте полной статьи);

- обзоры печатных работ по актуальным проблемам устойчивого развития горных территорий, объемом 20-25 страниц по заказу редакции.

К опубликованию также принимаются платные рекламные сообщения о новых материалах, технологиях, приборах и аппаратуре, соответствующие тематике журнала.

Все работы должны соответствовать тематике журнала. Предоставленные рукописи проходят этапы предварительного и итогового рецензирования, и в случае необходимости, направляются авторам на исправление и доработку. Рукописи в журнале публикуются на русском либо английском языках, аннотации на русском и английском языках.

Журнал публикует исключительно оригинальные статьи. Автор несет полную ответственность за соблюдение этого требования. Рукописи, не принятые к опубликованию, авторам не возвращаются. Редакция также не возвращает присылаемые материалы.

Редакция оставляет за собой право производить сокращение и редакторскую правку текста статьи. Исправления в тексте и иллюстрациях авторы могут вносить только на стадии подготовки статьи к набору. Корректура авторам для просмотра не высылается.

Несоблюдение правил оформления рукописи приведет к отклонению статьи.

Публикация бесплатна для авторов статей, написанных по заказу редакции, и для аспирантов.

За сведения в рекламных материалах редакция ответственности не несет.

Перепечатка допускается только с разрешения редакции и с обязательной ссылкой на журнал «Устойчивое развитие горных территорий».

\section{Инструкция для авторов}

В редакцию необходимо предоставить следующие материалы:

- статья (структуру и правила оформления смотри ниже); представляется как в бумажном (2 экз.), так и в электронном виде. Второй экземпляр обязательно подписывается авторами;

- на отдельном листе: сведения об авторах, содержащие фамилию, имя, отчество, ученую степень, звание, название организации, служебный и домашний адрес и телефоны, e-mail (если есть) и указание, с кем из авторов предпочтительнее вести переписку;

- направление от организации, если предоставляемые материалы являются результатом работы, выполненной в этой организации; в направлении следует указать название рубрики журнала;
- экспертное заключение или другой документ, разрешающий опубликование в открытой печати, утвержденные руководителем организации и заверенные гербовой печатью (представляют только авторы из России);

- компакт-диск, содержащий обязательный пакет электронных файлов (подробные инструкции приведены ниже);

- рекомендации для переводчика, включающие научные термины, ключевые слова, сокращения, фамилии и т. п. (если предполагается издание переводного варианта за рубежом)

\section{Правила оформления статьи}

На первой странице должны быть указаны: УДК; название статьи на русском языке (прописными буквами, без кавычек, переносы не допускаются, точка в конце не ставится, подчеркивание не используется), кегль 14 полужирный, выравнивание по центру; инициалы и фамилии авторов (кегль 
12 полужирный курсив, выравнивание по правому краю), название учреждения, город, страна представляющих рукопись для опубликования.

Текст статьи набирается шрифтом Times New Roman размером 14 пт через одинарный интервал, выравнивание по формату. Подзаголовок - шрифт курсивный, выравнивание по левому краю. При написании статьи используются общепринятые термины, единицы измерения и условные обозначения, единообразные по всей статье. Расшифровка всех используемых авторами обозначений дается при первом употреблении в тексте. Буквы латинского алфавита набираются курсивом, буквы греческого алфавита - прямым шрифтом. Математические символы $\lim , \lg , \ln , \arg$, const, sin, cos, min, max и т.п. набираются прямым шрифтом. Символ не должен сливаться с надсимвольным элементом в химических элементах $\left(\mathrm{H}_{2} \mathrm{O}\right)$ и единицах измерений $\left(\mathrm{MBT} / \mathrm{cm}^{2}\right)-$ прямым (обычным) шрифтом. Не следует смешивать одинаковые по написанию буквы латинского, греческого и русского алфавитов, использовать собственные макросы. Буквы $I$ и $J$, v и v, e и $l, h$ и $n, q$ и $g, V$ и $U, O$ (буква) и 0 (нуль) должны различаться по начертанию.

Между цифровым значением величины и ее размерностью следует ставить знак неразрывного пробела. Переносы в словах либо не употреблять, либо пользоваться командой «расстановка переносов». Не использовать в тексте для форматирования знаки пробела. Различать дефис «-», знак минус «-» и тире «-».

Формулы создаются с помощью встроенного редактора формул Microsoft Equation с нумерацией в круглых скобках - (2), выравниваются по правому краю, расшифровка всех обозначений (букв) в формулах дается в порядке упоминания в формуле. Формулы должны быть аккуратно набраны на компьютере. Во избежание недоразумений и ошибок редакция рекомендует авторам использовать в формулах буквы латинского, греческого и других (не русских) алфавитов; при наборе формул необходимо соблюсти размеры по умолчанию. Следует учитывать, что при верстке формулы должны помещаться на половине страницы (8 см). Большие формулы необходимо будет разбивать на отдельные фрагменты. Фрагменты формул по возможности должны быть независимы (при использовании формульного редактора каждая строка - отдельный объект). Нумерацию и по возможности знаки препинания следует ставить отдельно от формул обычным текстом. Нумеровать следует только те формулы, на которые есть ссылки в тексте.

Таблицы, рисунки, фотографии размещаются внутри текста и имеют сквозную нумерацию по статье (не по разделам!) и собственные заголовки. Названия всех рисунков, фотографий и таблиц приводятся на русском языке 11 кеглем, курсивом. Нумерация обозначений на рисунках дается по порядку номеров по часовой стрелке или сверху вниз. Рисунки необходимо выполнять в компьютерном виде, желательно в программе Word 97, Corel Draw (до 13 версии) по следующим правилам: ширина рисунка не более $8 \mathrm{cm;} \mathrm{толщина} \mathrm{ли-}$ ний: основных - 1 пт, вспомогательных - 0,5 пт; для обозначений в поле рисунка использовать шрифт Times New Roman размером - 9 пт. Рисунки с большим количеством деталей (сложные схемы, графики) размещаются на всю ширину страницы (16,5 см). Векторные рисунки записываются в от- дельные файлы документов. Фотоснимки должны быть контрастными и выполненными на матовой бумаге. Отсканированные фотографии записываются в файлы в формате TIFF, JPEG. Сканировать изображение следует с разрешением 300 dpi для контрастных черно-белых рисунков и 600 dpi - для полутоновых. Цветные иллюстрации допускаются по согласованию с редакцией.

Обозначения, термины, иллюстративный материал, список литературы должны соответствовать действующим ГОСТ.

Библиографические ссылки в списке литературы нумеруются в той последовательности, в какой упоминаются в тексте. Описание литературных источников по ГОСТ 7.0.5-2008.

\section{Приложения к статье}

1. Аннотация (на отдельной странице - не более 100 слов). В ней не рекомендуется использовать формулы и ссылки на литературу. Если рукопись подается на русском языке, то аннотация должна быть продублирована на английском с указанием названия статьи, фамилий и инициалов авторов на этих языках. Если рукопись подается на английском языке, необходимо привести также аннотацию на русском. Аннотация печатается шрифтом Times New Roman (12 кегль) в одном файле в следующем порядке: название статьи, авторы, наименование организации, текст аннотации на русском языке; далее, через 2 строки, в той же последовательности на английском языке. Аннотация также публикуется на сайте журнала www.naukagor.ru. (на русском и английском языках).

2. Сведения об авторах на русском и английском языках печатается шрифтом Times New Roman (10 кегль) и должно содержать следующую информацию: должность, научное звание, ученая степень, награды и научные премии, круг научных интересов, количество публикаций, место работы, e-mail, номер телефона.

3. Фотографии авторов для резюме в формате TIFF или JPEG (300 dpi).

4. Реферат статьи (от 300 слов). Параметры страницы: формат A4 (210х297 мм); межстрочный интервал полуторный; шрифт Times New Roman (12 кегль) в одном файле в следующем порядке: наименование статьи, авторы, наименование организации, реферат на русском языке; далее, через 2 строки, в той же последовательности - на английском языке.

5. Электронная версия статьи представляется в редакцию на CD-R-диске или по электронной почте. Запись файлов выполняется в текстовом редакторе Microsoft Word (расширения .doc или .rtf), для набора формул применять редактор Equation 3.0.

Должны присутствовать следующие файлы:

- основной, содержащий текст статьи, включая формулы, таблицы, рисунки, подрисуночные подписи, список литературы, аннотация и ключевые слова на русском и английском языках;

- содержащий только иллюстрации, которые должны быть именованы таким образом, чтобы было понятно, к какой статье они принадлежат и каким по номеру рисунком статьи они являются. Каждый файл должен содержать один рисунок.

Электронная и бумажная версии статьи должны быть абсолютно идентичны.

Если авторы не могут полностью или частично удовлетворить требования по оформлению рукописи на диске, им необходимо проконсультироваться в редакции. 


\section{Адрес редакции:}

Россия, РСО-Алания, 362021, Владикавказ, ул. Николаева, 44. Северо-Кавказский горно-металлургический институт (государственный технологический университет).

Редакция журнала «Устойчивое развитие горных территорий».

Тел.: 8(8672) 40-73-60; 8(8672) 40-72-28 (служ.),+7(918)707-39-25 (моб.). E-mail: editor@naukagor.ru.

\section{DEAR COLLEAGUES!}

In accordance with the Conclusion of the Presidium of the Higher Attestation Commission of the Ministry of Education and Science of the Russian Federation from 12.19.2014 №47/307 from 2015 articles for publication in the journal "Sustainable Development of Mountain Territories" are accepted for the following Industries and groups of Sciences:

25.00.00 Earth Sciences (all branches of the Earth Sciences);

05.00.00 Engineering Sciences (three groups of industries):

05.05.00 Transport, Mountain and Building Mechanical Engineering,

05.13.00 Computer Sciences, Computer facilities and Management,

05.14.00 Energetics.

According to the gradation of Sciences accepted in international citation systems Scopus and Web of Science articles for publication in the journal "Sustainable development of mountain territories" are accepted by the following branches and groups of Sciences:

1. Engineering;

2. Earth and Planetary Sciences;

3. Environmental Science.

The journal «Sustainable Development of the Mountain Territories» publishes:

- articles interpreting the new scientific- research results of volume not more than 10 type written pages including illustrations and tables;

- brief messages containing information on the important results of the preliminary research of volume 3-5 pages (these materials can be used in the full article text);

- reviews of the typewritten articles on the actual problems of the sustainable development of the mountain territories, volume 20-25 pages by the editor's order, also the paid advertisements concerning new materials, devices and equipment in terms of the journal theme are accepted to the publication.

All papers must correspond to the journal theme.

The presented manuscripts pass the preliminary and total reading stages and if necessary are sent back to the authors for the correction and finishing.

The manuscripts are published in Russian and in English, the abstracts in Russian and in English as well.

The journal publishes only the original articles. The author is fully responsible for the requirement.

The manuscripts are not returned to the authors in case of being rejected in publication. The editor has a right to make reductions and corrections of the article text. All corrections in the text and figures can be done by the authors only at the stage of the typesetting preparations. The correction isn't sent to the authors for revision.

The infringement of the manuscript lay-out rules will lead to the publication delay or the article rejection.

The publication is free of charge for the authors, the fees aren't paid.

The authors (or the author) of each article having been published in the regular number of the journal have the right to get the authors' copies or their articles from the editorship.

The editorship isn't responsible for the advertisement information.

Reprinting is allowed only with the editorship permission with the obligatory references to the journal «Sustainable Development of the Mountain Territories»».

\section{INSTRUCTIONS FOR THE AUTHORS}

The following materials should be presented to the editorial office:

- an article, both in paper ( 2 copies) and in the electronic version. The second copy must be signed by the authors;

- a separate sheet with the information: about the authors (surname, name, patronymic name, scientific degree, rank, name of the organization, office and home address and telephone number, E-mail (if exists) and the reference to the author to contact with;

- a confirmation from the organization in case the presented materials are the result of the work carried out in that organization; the journal heading should be pointed out in the confirmation;
- an expert conclusion or any other document allowing the publication in the open press confirmed by the organization head and proved with the stamped seal; the expert conclusion is presented only by the authors from Russia;

- CD or a diskette with the files containing an obligatory set of the electronic files;

- recommendations for the translation including scientific terms, key words, cuttings, surnames, etc. (if the translated version is supposed to be published abroad).

\section{THE ARTICLE LAY-OUT RULES}

The following information should be pointed out on the first page: the article heading in Russian (in capital letters, without quotation marks, without division of a word, without a full stop at the end, underlining isn't used), point 14 semi bold, centre 
aligning; the authors surnames (point 12 semi bold type, the right-edge aligning), the organization name, town, country, a person responsible for the manuscript publication.

The article text is typed in Times New Roman (14 pt) through an ordinary interval aligning along the format. A subtitle is typed in italics, aligning along the left edge. The common terms, measurement units and conventional symbols similar for the whole article are used. The decoding of all symbols is given for the first text use. The Latin alphabet letters are typed in the italics while the Greek and Latin letters in the straight type. The mathematical symbols lim, lg, ln, arg, const, sin, cos, min, max, etc. are typed in the straight type. The symbol shouldn't coincide with the over symbol element in the chemical elements $\left(\mathrm{H}_{2} \mathrm{O}\right)$ and measurement units $(\mathrm{MBt} / \mathrm{cmI})$ and must be of the straight (ordinary) type. You shouldn't mix similar written letters of the Latin, Greek and Russian alphabets and should use the proper macros. The letters L and J, e and I, h and n, q and g, V and U, O (letter) and 0 (zero) must differ in inscribing.

There must be a sign of the continuous gap between a value figure meaning and its dimension. The hyphens are not used otherwise the command «hyphens arrangement», the gap signs also mustn't be used in the text for the lay-out and a hyphen «-»), a minus sign «-», and a dash «-» should be differentiated.

The formulas are designed with the help of the built-in formulas processor (Microsoft Equation), the enumeration being done in the round brackets (2), aligned along the right edge; the decoding of all signs (letters) in the formulas is given in the order of the formula reference. The formulas should be typed on computer. To avoid the errors and misunderstandings, the editorial staff recommends the authors to use the Latin, Greek and other (not Russian) alphabet letters in the formulas and to keep to the omission sizes while the formulas printing. One should account that during the page-making the formulas must be placed on the half of the page $(8 \mathrm{sm})$, the big formulas being split into the separate fragments. If possible, the fragments must be independent; each line is a separate object. The enumeration and stops should be put into an ordinary text separately from the formulas. Only the formulas having the text references should be numerated.

The tables, pictures and photos are placed inside the text and must have a through numeration along the text (not by the sections!) and their own headings. The titles of all tables, pictures and photos are presented in Russian (11 point, italics). The numeration of the picture symbols is given in clockwise order or from up to down. The pictures should be done in the computer form, preferably in Word 97 program using the following rules: a picture width - not more than $8 \mathrm{sm}$, a line thickness: the main $-1 \mathrm{pt}$, auxiliary $-0,5 \mathrm{pt}$; for the symbols in the picture area - «Times New Roman» type of 9 pt must be used.

The pictures with the great amount of details (complex schemes, graphs) are placed on the whole page width $(16,5 \mathrm{sm})$. The vector pictures are written into the separate documentary files. The photo pictures must be contrast and performed on the mat paper. The scanned photos are written into the files of TIFF, JPEG format. To scan the image one should use the resolution of $300 \mathrm{dpi}$ for the contrast black-white pictures and $600 \mathrm{dpi}$ for semitone ones. The colour illustrations are admitted on the editorial is agreement.

All symbols, terms and illustrations should correspond to the operative standards.
The literature sources should be numerated in the order of the text reference (not in the alphabetic order). The literature sources list is given as a total list at the end of the article. The list is composed according to the references consequence in the text. References should be designed according to GOST 7. 1-84. All references to the literature sources are applied in the square brackets [3].

\section{SUPPLEMENTS TO THE ARTICLE}

1. Abstract (on a separate page - not more than 100 words), without formulas and literature references. In case a manuscript is presented in Russian, the abstract should be repeated in English with the article heading, surnames and names in this language. In case a manuscript is presented in English, the Russian variant must be supplied. The abstracts are typed in Times New Roman (12 point) in one file in the following order: the article heading, the authors, the name of the organization, the abstract text in Russian with the further information in 2 lines in the same sequence in English. The abstracts are also published in the journal site www. naukagor.ru (in Russian and in English).

2. Resume in Russian and English is typed in Times New Roman (10 point) and must contain the following information: a place of work, a post, a scientific rank, degree, awards and scientific grants, professional experience, the main sphere of the scientific interests, the number of the publications for each author.

3. The authors' photographs for the resume should be done in TIFF or JPEG format.

4. The essay text (one page) for the publication in the essay journals. The page parameters: A4 $(210 \times 297 \mathrm{~mm})$ format; interline interval - one and a half; Times New Roman (12 point) type in one file in the following order: the article heading, the authors, the organization name, an essay in Russian, then in 2 lines in English.

5. The electronic version of the article.

To reduce the material preparation time for the publication and to avoid errors during typing, the materials should be presented on the CD-R disks. The files are written in the word processor Microsoft Word (doc or rtf), the formulas being printed with Equation 3.0. The author's name should be pointed out in the file title. Several file copies are preferable.

The following files are to be present on the diskette:

- the main file containing the article text, formulas, tables, pictures, under picture signatures, reference list, abstracts in Russian and English;

- the file containing only the illustrations for to the exact articles or pictures. Each file must have one picture.

The electronic and paper versions should be identical.

In case the authors fail to meet the requirements on the manuscript design on the disk, they should consult the editorials.

The editorial office address: 44 Nikolaev Str., Vladikavkaz, North Ossetia-Alania, Russia, 362021, The North Caucasian Institute of Mining and Metallurgy (The State Technological University), the Editorials of the journal «Sustainable Development of Mountain Territories».

Phone: +7(8672) 40-73-60, +7(918)707-39-25 (mob.).

E-mail:editor@naukagor.ru. 

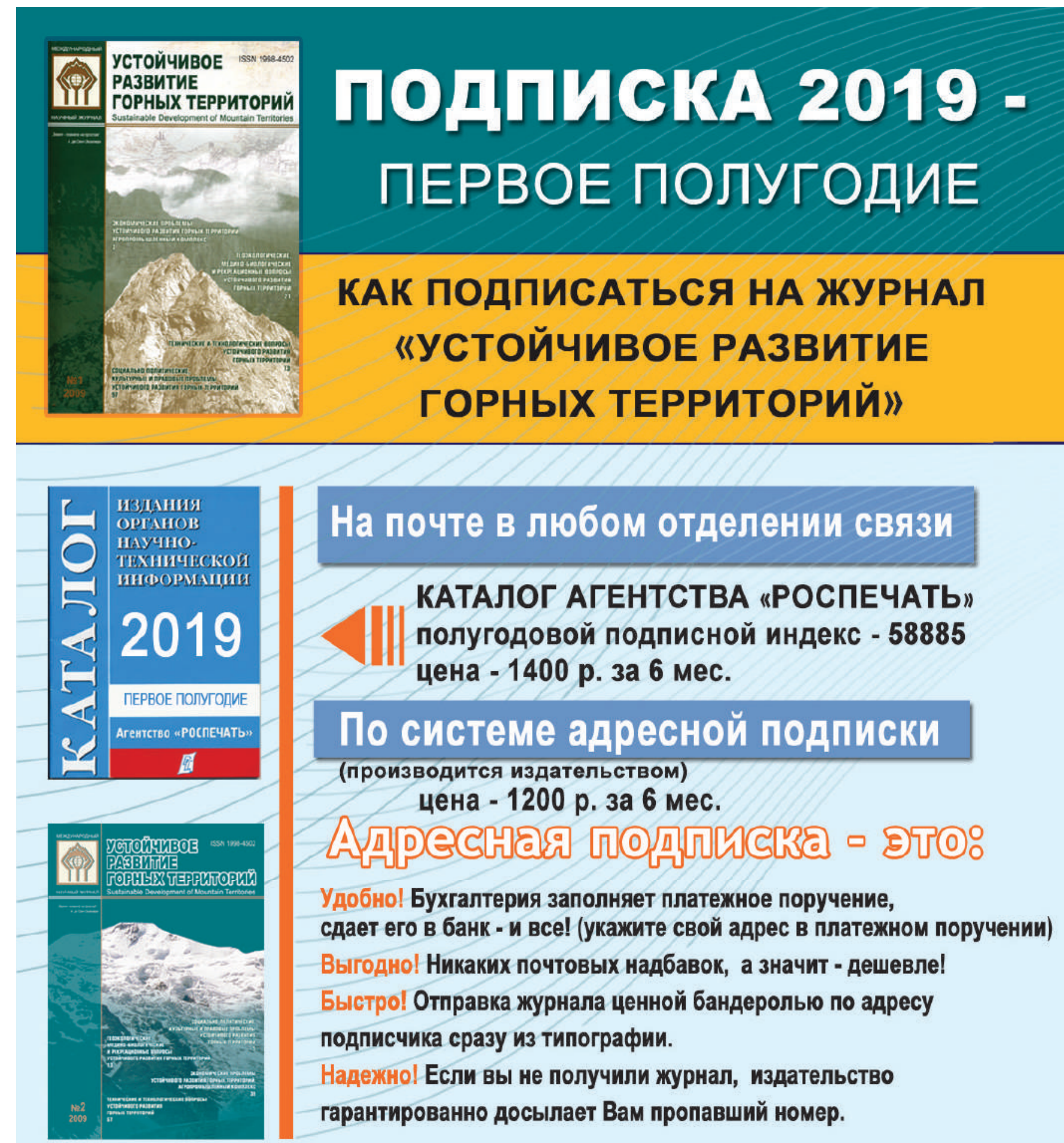

\section{На почте в любом отделении связи}

КАТАЛОГ АГЕНТСТВА "РОСПЕЧАТЬ" полугодовой подписной индекс - 58885 цена - 1400 р. 3 а 6 мес.

\section{По системе адресной подписки (производится издательством) цена - 1200 р. $з$ а 6 мес.

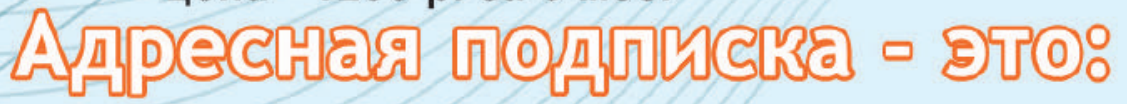

Удобно! Бухгалтерия заполняет платежное поручение, сдает его в банк - и все! (укажите свой адрес в платежном поручении) Выгодно! Никаких почтовых надбавок, а значит - дешевле! Быстро! Отправка журнала ценной бандеролью по адресу подписчика сразу из типографии.

НадежноІ Если вы не получили журнал, издательство гарантированно досылает Вам пропавший номер.

Оплату адресной подписки произвести по реквизитам: 362021, РСО-Алания, ул. Николаева, 44 ФГББОУ ВО "СЕВЕРО-КАВКАЗСКИЙ

ГОРНО-МЕТАЛЛУРГИЧЕСКИЙ ИНСТИТУТ (ГТУ)" УФК ПО РСО-АЛАНИЯ л/c $20106 \times 45350$

(ИНН 1501002522 Сев-Кав ГМИ (ГТУ)) p/c № 40501810590332000003 БИК 049033001 КПП 151601001

В отд. НБ РСО-Алания, Г. Владикавказ /Копию квитанции об оплате присылать на e-mail: editor@naukagor.ru

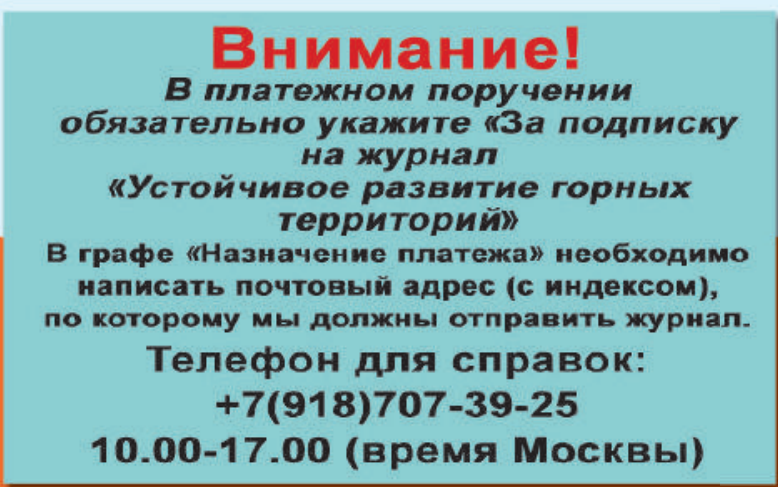

Стоимость адресной подписки для любого региона РФ НДС не облагается Стоимость доставки включена. 


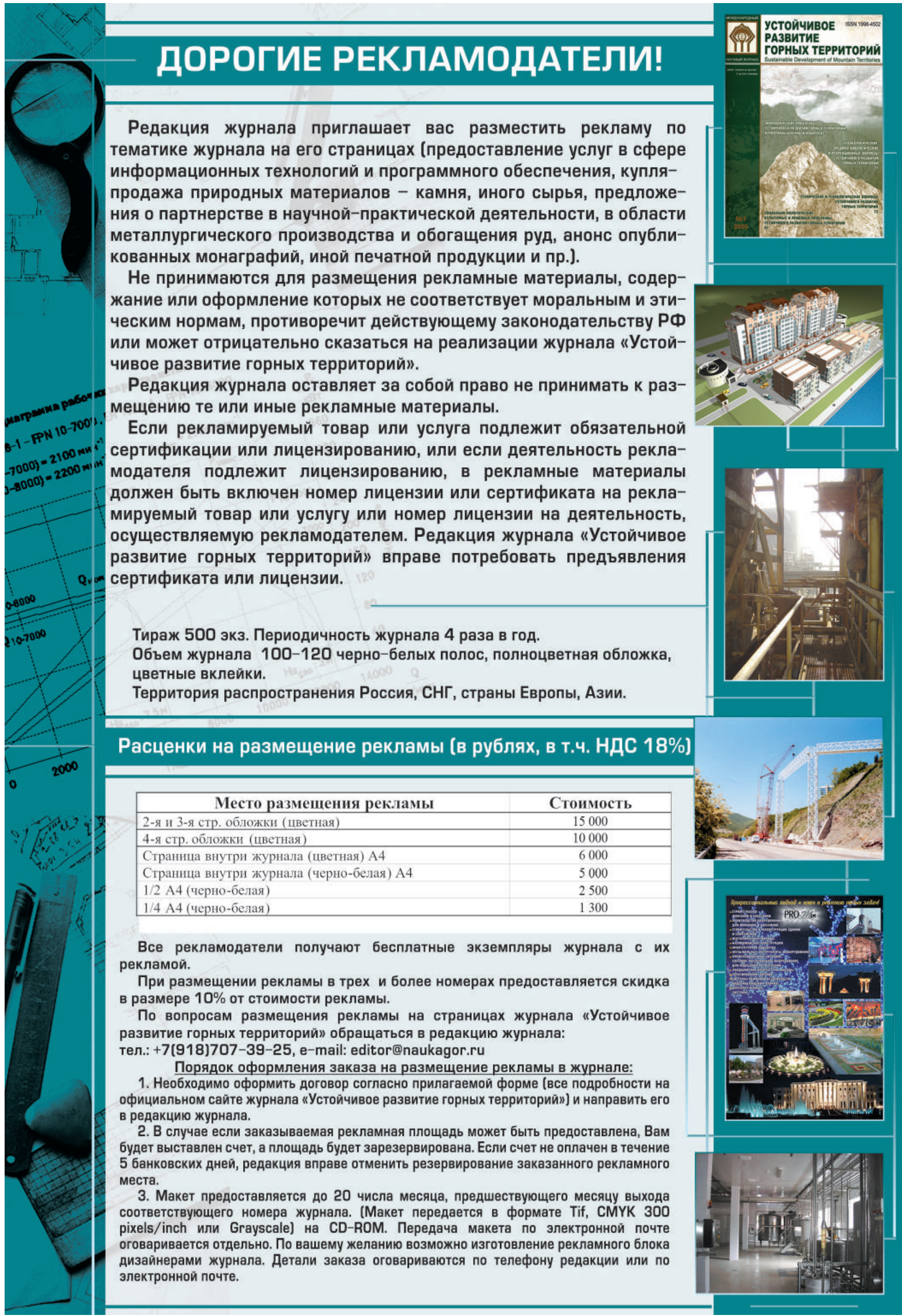




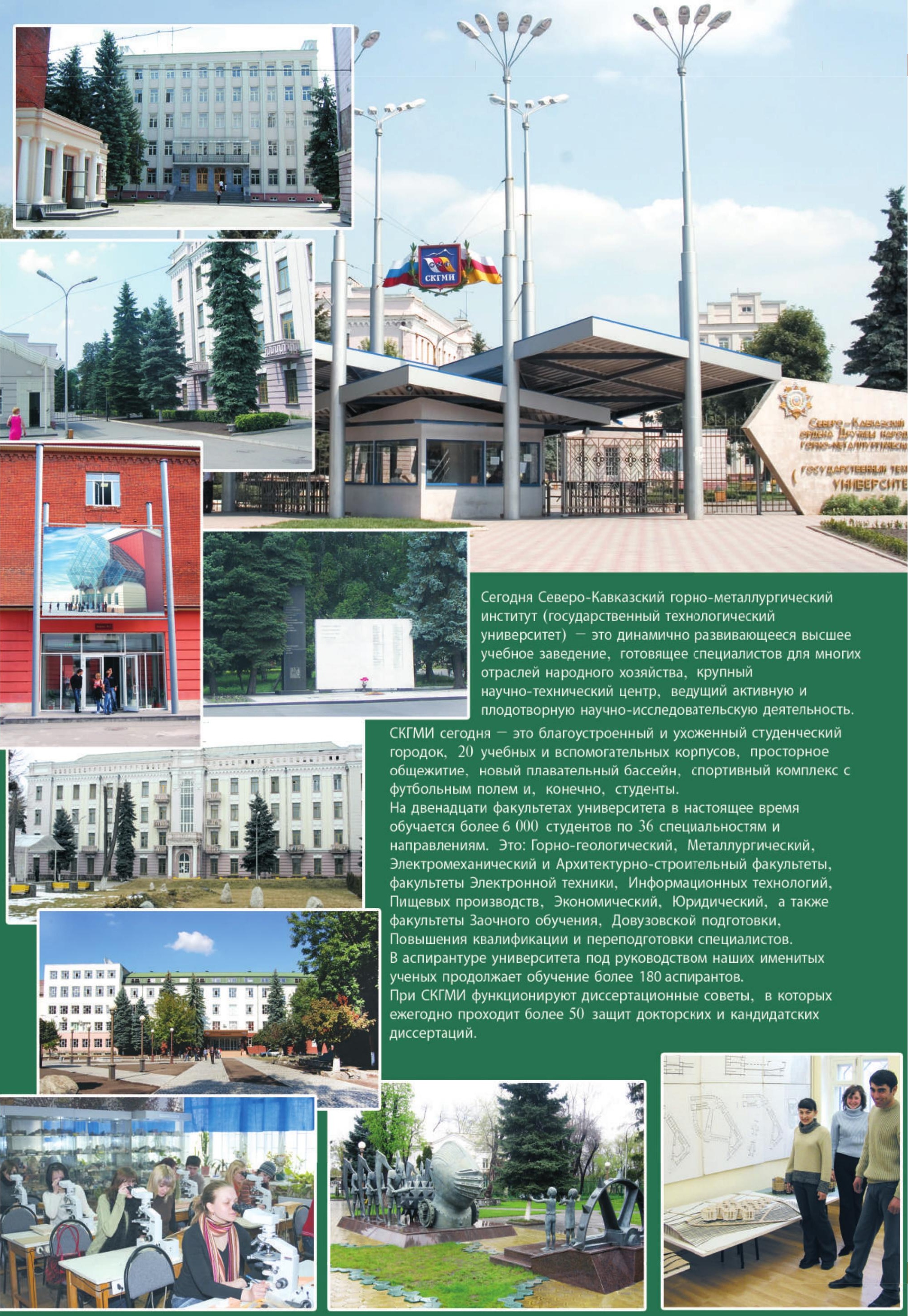


